\title{
Kwaliteit van leven van Cara-patiënten in het Nederlands Astmacentrum Davos : beloop en determinanten
}

Citation for published version (APA):

Schoot, T. (1996). Kwaliteit van leven van Cara-patiënten in het Nederlands Astmacentrum Davos : beloop en determinanten. [Doctoral Thesis, Maastricht University]. Datawyse / Universitaire Pers Maastricht. https://doi.org/10.26481/dis.19960202ts

Document status and date:

Published: 01/01/1996

DOI:

10.26481/dis.19960202ts

Document Version:

Publisher's PDF, also known as Version of record

Please check the document version of this publication:

- A submitted manuscript is the version of the article upon submission and before peer-review. There can be important differences between the submitted version and the official published version of record. People interested in the research are advised to contact the author for the final version of the publication, or visit the DOI to the publisher's website.

- The final author version and the galley proof are versions of the publication after peer review.

- The final published version features the final layout of the paper including the volume, issue and page numbers.

Link to publication

\footnotetext{
General rights rights.

- You may freely distribute the URL identifying the publication in the public portal. please follow below link for the End User Agreement:

www.umlib.nl/taverne-license

Take down policy

If you believe that this document breaches copyright please contact us at:

repository@maastrichtuniversity.nl

providing details and we will investigate your claim.
}

Copyright and moral rights for the publications made accessible in the public portal are retained by the authors and/or other copyright owners and it is a condition of accessing publications that users recognise and abide by the legal requirements associated with these

- Users may download and print one copy of any publication from the public portal for the purpose of private study or research.

- You may not further distribute the material or use it for any profit-making activity or commercial gain

If the publication is distributed under the terms of Article $25 \mathrm{fa}$ of the Dutch Copyright Act, indicated by the "Taverne" license above, 
Kwaliteit van leven van Cara-patiënten in het Nederlands Astmacentrum Davos

Beloop en determinanten 
Druk:

Datawyse Maastricht / Krips Repro Meppel

ISBN 90-9009100-9 


\title{
Kwaliteit van leven van Cara-patiënten in het Nederlands Astmacentrum Davos
}

\author{
Beloop en determinanten
}

\author{
PROEFSCHRIFT \\ ter verkrijging van de graad van doctor \\ aan de Rijksuniversiteit Limburg te Maastricht, \\ op gezag van de Rector Magnificus, Prof, mr. M.J. Cohen \\ volgens het besluit van het College van Dekanen, \\ in het openbaar te verdedigen \\ op vrijdag 2 februari 1996 om 14.00 uur
}

door

Tom van der Schoot

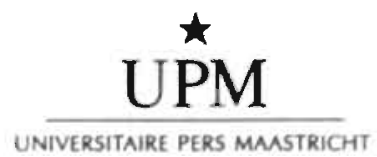




\section{Promotor:}

Prof. dr. A.P.W.M. Appels

\section{Co-promotor:}

Dr. A.A. Kaptein (Rijks Universiteit Leiden)

\section{Beoordelingscommissie:}

Prof. dr. J.J.C.B. Bremer (voorzitter)

Dr. J. Dekker (Nivel)

Prof. dr. E.C. Klip (Rijksuniversiteit Groningen)

Prof. dr. J.A. Knottnerus

Prof. dr. E.F.M. Wouters

Het onderzoek waarvan in dit proefschrift verslag wordt gedaan is mede mogelijk gemaakt door een financięle bijdrage yan de Vereniging Nederland-Davos.

De publikatie van dit onderzoek in dit proefschrift is mede mogelijk gemaakt door een financiële bijdrage van het Nederlands Astma Fonds. 


\section{INHOUDSOPGAVE}

INLEIDING

1. CHRONISCHE ASPECIFIEKE RESPIRATOIRE AANDOENINGEN 8

1.1. Definiêring van Cara $\quad 8$

1.2. Epidemiologische gegevens 10

1.3. Verschillende niveaus van Cara-zorgverlening binnen de Nederlandse gezondheidszorg

1.4. Psychologische en sociale aspecten van Cara

Psychologische en sociale factoren die de aanleiding vormen voor het

ontstaan van (symptomen) van Cara

Psychologische en sociale gevolgen van Cara

Psychologische en sociale kenmerken opgevat als determinanten van

het beloop van Cara

2. LONGREVALIDATIE

2.1. Definitie van longrevalidatie 25

2.2. Doelstelling en doelgroep 26

2.3. De inhoud en organisatie van longrevalidatie in het algemeen en die van het Nederlands Astmacentrum Davos in het bijzonder

2.4. Effectonderzoek naar longrevalidatie

3. VRAAGSTELLINGEN EN METHODE

3.1. Inleiding

3.2. Vraagstellingen

3.3. Methode

Samenstelling van de onderzoeksgroep

Variabelen en meetinstrumenten 48

Afhankelijke en onafhankelijke variabelen en statistische procedure per vraagstelling

3.4. Onderzoeksprocedure

4. RESCHRIJVING VAN KENMERKEN VAN DE PATIENTEN, OPGENOMEN IN HET NEDERLANDS ASTMACENTRUM DAVOS 59

4.1. Inleiding 59

4.2. Medisch-somatische kenmerken 59

4.3. Medische consumptiekenmerken 61

4.4. Kwaliteit van leven-kenmerken 62

Het functionele aspect van kwaliteit van leven 62

Psychologische aspecten van kwaliteit van leven 64

Sociale aspecten van kwaliteit van leven $\quad 66$

4.5. Samenvatting en conclusies 66 
5. VERGELIJKING VAN SCORES MET BETREKKING TOT KENMERKEN VAN DE PATIËNTENPOPULATIE OVER DE VERSCHILLENDE MEETMOMENTEN

5.1. Inleiding

5.2. Vergelijking van scores van respondenten en non-respondenten 69

5.3. Medische consumptie

5.4. Kwaliteit van leven

5.5. Samenvatting en conclusies

6. DETERMINANTEN VAN EFFECTEN VAN LONGREVALIDATIE IN HET NAD

6.1. Inleiding

6.2. Determinanten van verbetering en verslechtering van aspecten van medische consumptie en ervaren beperkingen in dagelijkse activiteiten

Determinanten van verbetering van ervaren beperkingen in dagelijkse activiteiten

Determinanten van verslechtering van ervaren beperkingen in dagelijkse activiteiten

Determinanten van verandering van het aantal huisartsbezoeken

Determinanten van verandering van het aantal specialistbezoeken

Determinanten van verbetering van het aantal ziekenhuisopnamen

Determinanten van verslechtering van het aantal ziekenhuisopnamen

Determinanten van verbetering van het aantal ziekenhuisdagen

Determinanten van verslechtering van het aantal ziekenhuisdagen

Determinanten van verbetering van de mate van oraal corticosteroïgebruik

Determinanten van verslechtering van de mate van het oraal

corticosieroïdgebruik

6.3. Veranderingen in psychologische en longfunctiekenmerken als determinanten van effecten op ervaren beperkingen en op aspecten van medische consumptie

7. DISCUSSIE

7.1. Kenmerken van de patiëntenpopulatie

7.2. Het beloop van de kenmerken over de verschillende meetmomenten 97

Enkele conclusies over de waarde van longrevalidatie in het NAD

7.3. Determinanten van effecten van longrevalidatie in het NAD

7.4. Opmerkingen over de methode

7.5. Implicaties voor vervolgonderzoek

7.6. Implicaties voor behandeling 
In dit proefschrift wordt verslag gedaan van een gedragswetenschappelijk onderzoek onder patiēnten die waren opgenomen in het Nederlands Astmacentrum Davos (NAD), gelegen in de Zwitserse Alpen op ongeveer 1560 meter boven de zeespiegel. Het centrum is én van de zes intramurale Nederlandse gezondheidszorginstellingen op het gebied van de behandeling van patiènten met chronische aspecifieke respiratoire aandoeningen (Cara) ${ }^{4}$. In het NAD vindt longrevalidatie plaats, een behandelvorm met een uitgesproken multidisciplinair karakter.

Het onderzoek waarover verslag wordt gedaan heeft zowel een beschrijvend als een evaluerend karakter. Het belangrijkste doel van dit onderzock is na te gaan wat de waarde is van longrevalidatie voor volwassen patiénten die voor behandeling werden verwezen naar het NAD. Hiertoe worden zowel kenmerken bij opname, als het beloop van deze kenmerken over verschillende meetmomenten later, beschreven. Tevens wordt aan de hand van deze kenmerken aangegeven hoeveel patiěnten verbeteren, onveranderd blijven, en verslechteren en worden de profielen beschreven van de groepen patiënten die wel en die niet van een behandeling in het NAD profiteren. Het profijt wordt uitgedrukt aan de hand van ervaren beperkingen in dagelijkse activiteiten en van verschillende aspecten van medische consumptie.

Met dit proefschrift wordt beoogd een bijdrage te leveren aan wetenschappelijk onderzoek naar gedragswetenschappelijke aspecten van Cara. Tevens dient het een bijdrage te leveren aan de evaluatie van de behandeling van patiènten die in het NAD worden opgenomen en is oogmerk ervan aanwijzingen te geven voor de indicatiestelling voor opname en voor het aangeven van belangrijke interventie-accenten ter verhoging van de effectiviteit van behandeling.

In het eerste hoofdstuk zullen relevante thema's met betrekking tol Cara worden besproken. In hoofdstuk 2 komen doelstellingen, inhoud en organisatie van longrevalidatie in het algemeen en die van het NA.D in het bijzonder aan bod. Tevens zal een overzicht worden gepresenteerd van in de literatuur aangetroffen studies naar effecten van longrevalidatie. In het derde hoofdstuk worden de vraagsteliingen van het eigen empirisch onderzoek geformuleerd en wordt de methođe van onderzoek uiteengezet. De resultaten worden in de hoofdstukken 4,5 en 6 besproken. In hoofdstuk 7 worden de resultaten aan een nadere beschouwing onderworpen en worden aanbevelingen voor behandeling en onderzoek geformuleerd.

1 De overige Nederịandse gespecialiseerde intramurale instellingen op het gebied van Cara-behandeling zijn Beatrixoord te Haren, Dekkerswald te Groesbeek. Hornerheide te Horn, Heideheuvel te Hilversum en de Klokkenberg te Breda. 
In dit hoofdstuk zullen verschillende aspecten van Cara worden belicht. In de eerste plaats wordt het begrip Cara gedefinieerd (1.1.). Vervolgens zal inzicht worden gegeven in de epidemiologie van deze aandoening (1.2.) en worden de verschillende niveaus van Carazorgverlening binnen de Nederlandse gezondheidszorg beschreven (1.3.). De laatste paragraaf besteedt aandacht aan de psychologische en sociale aspecten van Cara (1.4.).

\subsection{Definiêring van Cara}

Cara is een chronische aandoening. 'Chronische ziekten is een verzamelterm voor ziekten die bij de huidige stand van de wetenschap niet (volledig) te genezen zijn. Ze worden in het algemeen omschreven als onomkeerbare aandoeningen, zonder uitzicht op volledig herstel en met een gemiddeld lange ziekteduur. De meest voorkomende chronische aandoeningen zijn kanker, chronische pijn, coronaire hartziekten, diabetes mellitus, reuma en Cara' (Tweede Kamer, 1991). Chronisch zieken zijn mensen die langdurig of regelmatig terugkerende gezondheidsklachten hebben als gevolg van een chronische ziekte (NCCZ, 1994).

Cara is een verzamelbegrip voor een aantal chronische aandoeningen van de luchtwegen, te weten 'astma', 'chronische bronchitis' en 'longemfyseem' (Sluiter, 1986). Het gemeenschappelijke kenmerk van deze aandoeningen zijn klachten van kortademigheid, die aanvalsgewijs en seizoensgebonden kunnen voorkomen, maar ook permanent kunnen bestaan. De ademhaling kan, wanneer er sprake is van een aanval, gepaard gaan met een piepend geluid bij uitademing. Ook kunnen, al dan niet in combinatie met kortademigheid langdurige, continue, of recidiverende klachten van hoesten met of zonder het opgeven van slijm bestaan. De verschillende manifestaties van Cara variëren individueel sterk in ernst en duur van de klachten. Tevens bestaat variatie in ervaren beperkingen in het uitoefenen van dagelijkse activiteiten.

In de Nederlandse literatuur worden verschillende redenen genoemd die pleiten voor de samenvoeging van de dirie aandoeningen, astma, chronische bronchitis en emfyseem, tot het begrip Cara. Van Herwaarden (1986) noemt de volgende:

- het is moeilijk de verschillende klinische beelden ten opzichte van elkaar af te grenzen; veel patiénten vertonen kenmerken van alle drie de aandoeningen.

- er zijn aanwijzingen dat bij het ontstaan van de verschillende klinische beelden dezelfde onderliggende mechanismen betrokken zijn, een opvatting die internationaal bekend staat als de 'Dutch hypothesis'. Het waren onderzoekers uit Groningen, onder leiding van Orie en Sluiter, die in de jaren zestig in de internationale literatuur met deze hypothese naar voren traden (Orie et al., 1961).

Fletcher (1959) introduceerde de overkoepeiende term 'chronic non-specific lung disease' (CNSLD), een term die kan worden beschouwd als het Angelsaksische equivalent van het in Nederland gehanteerde begrip Cara. De American Thoracic Society (1987) maakı inmiddels onderscheid tussen de termen astma en 'chronic obstructive pulmonary disease' (COPD). Onder laatstgenoemde term worden de aandoeningen chronische bronchitis en longemfyseem verstaan. Maar al te vaak echter wordt de term COPD in de literatuur op dezelfde wijze gebruikt als onze term Cara. Dit schept veel onduidelijkheid en verwarring en maakt een vergelijking tussen populaties lastig. 
Het Cara-begrip is in Nederland algemeen ingeburgerd en bruikbaar gebleken. Onderzoek in de afgelopen twee decennia naar de pathofysiologische mechanismen en het beloop van de aandoening heeft geleid tot een meer adequate omschrijving van de afzonderlijke aandoeningen in termen van astma, chronische bronchitis en longemfyseem. Hoewel een ruim aantal jaren werd uitgegaan van één groep van aandoeningen onder de noemer Cara, leiden recente bevindingen uiteindelijk tol de opvatting dat astma en COPD (complexe) aandoeningen zijn met naast een aantal overeenkomsten, ook belangrijkeverschillen in verschijningsvorm. beloop, pathologie en behandeling. Dat heeft ertoe geleid dat deze aandoeningen thans beschouwd en benaderd worden als onderscheiden syndromen. Een belangrijk verschil is de leeftijd waarop de aandoeningen zich manifesteren. Zo begint astma vooral in de kinderleeftijd, terwijl chronische bronchitis en longemfyseem zich voomamelijk op latere leeftijd voor het eerst voordoen. Ook de symptomen vertonen verschillen: een patiënt met astma kent aanvalsgewijze kortademigheid en is tussen de aanvallen door bijna geheel klachtenvrij. Een patiënt met COPD heeft daarentegen vrijwel voortdurend symptomen in de vorm van kortademigheid, hoesten en opgeven van slijm.

Voor een beschrijving van de afzonderlijke aandoeningen die onder het begrip Cara worden gerekend, wordt over het algemeen uitgegaan van definities die door het American College of Chest Physicians en de American Thoracic Society (1987) worden voorgesteld. Deze luiden als volgt:

1. Astma: 'is a clinical syndrome characterized by increased responsiveness of the tracheobronchial tree to a variety of stimuli. The major symptoms of asthma are paroxysms of dyspnea, wheezing, and cough, which may vary from mild and almost undetectable to severe and unremitting (status asthmaticus). The primary physiological manifestation of this hyperresponsiveness is variable airways obstruction' (pag. 228).

Voor het al of niet ontstaan van astma-klachten of -symptomen zijn zowel endogene als exogene factoren verantwoordelijk. Tot de endogene factoren rekent men: genetische factoren (hyperreactiviteit; allergie), hormonale factoren (bijnierschorshormonen als corticosteroïden; geslachtshormonen) en leeftijdsfasen. Tot de exogene factoren worden gerekend: infecties, allergenen (huisstofmijt, dierlijke epitheelcellen, haren en veren, schimmelsporen, stuifmeel, planten, meelstof, houtstof, schoonmaakmiddelen met enzymen, cosmetica, etc.), lichamelijke inspanning, chemische prikkels (tabaksrook, luchtverontreiniging, schoonmaakmiddelen, verf, sprays, conserveringsmiddelen, etc.), fysische prikkels (temperatuurswisselingen, mist, regen, koude, harde wind, etc.) en emotionele gebeurtenissen.

Over de factoren die het natuurlijk beloop en de prognose van de aandoening bepalen is nog weinig bekend. De prognose wordt als ongunstig beschouwd als er sprake is van een emstige bronchusobstructie, die weinig reversibel is, waarbij veel uitlokkende factoren een rol spelen en een debuut van de aandoening bestaat op jonge leeftijd.

2. Chronische bronchitis: verwijst naar 'the condition of subjects with chronic or recurrent excess mucus secretion into the bronchial tree' (pag. 226). Chronisch wordt gedefinieerd als 'occuring on most days for at least three months of the year for at least two successive years' (pag. 226). De overmatige afscheiding van slijm mag niet worden veroorzaakt door andere ziekten, zoals bronchiëctasieèn of tuberculose. In de meeste gevallen gaat de sputumproduktie gepaard met chronisch hoesten. De produktie van slijm is een belangrijke oorzaak van de luchtwegobstructie.

3'. Longemfyseem: 'a condition of the lung characterized by abnormal permanent enlargement of the airspaces distal to the terminal bronchiole, accompanied by destruction of their 
walls, and without obvious fibrosis' (pag. 225). In klinische termen spreken we van een situatie waar blijvende veranderingen zijn opgetreden in de longen, met name elasticiteitsverlies, waardoor de uitademing wordt belemmerd en de functie van de longen is verminderd.

De American Thoracic Society maakt, zoals gezegd, onderscheid tussen astma enerzijds en COPD anderzijds. COPD wordt gedefinieerd als een stoomis gekenmerkt door een abnormale longfunctie die gedurende enkele maanden observatie niet noemenswaardig verandert. Tot COPD worden de aandoeningen emfyseem en chronische bronchitis gerekend. Als de voornaamste oorzaak voor COPD wordt het gedurende lange tijd roken van sigaretten gezien. Roken is niet alleen een aspecifieke prikkel op korte termijn, maar ook een belangrijke factor bij het ontstaan en de prognose van chronische bronchitis en emfyseem. Daarbij is de mate en de duur van het roken een belangrijke determinant gebleken voor het ontstaan en het beloop van COPD. Ook patiènten die in kolenmijnen hebben gewerkt en daar gedurende langere tijd in aanraking zijn geweest met koolstof, hebben een verhoogde kans op het ontwikkelen van COPD op latere leeftijd (American Thoracic Society, 1987).

Bij de diagnostiek is het van belang aanwijzingen voor differentiêle diagnoses te verzamelen. Hieronder vallen de diagnoses sinusitis, pneumonie, longcarcinoom/metastasen, restrictieve longaandoeningen (fibrose, asbestose, etc.). TBC, decompensatio cordis, hyperventilatie, refluxoesofagitis en bijwerkingen (prikkelhoest, bronchospasmen) van ACE-remmers.

\subsection{Epidemiologische gegevens}

Cara is een veel voorkomende aandoening. De prevalentie ervan zal, zo blijkt ụit betroụwbare voorspellingen, in de komende decennia (net als die van andere chronische aandoeningen), ondanks de verbeterde medische zorg, verder toenemen. Verwacht wordt dat iti net jaar 2010 ruim 4 miljoen Nederlandẹs lijden aan een chronische aandoening, waarvan de voomaamste kanker, Cara, diabeies mellitus en reuma zullen zijn (RIVM, 1993; Stuurgroep Toekomstscenario's Gezondheidszorg, 1992). Voor wat betreft Cara wordt verwacht dat de prevalentie ervan in de jaren tussen 1990 en 2005 zal stijgen met 15\% (Stuurgroep Toekomstscenario's Gezondheidszorg, 1990).

Op grond van bevolkingsonderzoek wordt momenteel de prevalentie van Cara op ongeveer 100 tot 200 per 1000 personen per jaar geschat. Verder blijkt dat 10 tot $20 \%$ van de volwassen mannen en 5 lot $10 \%$ van de volwassen vrouwen aan een dermate ernstige vorm van Cara lijdt, dat ten minste een regelmatig bezoek aan de huisarts nodig is (Van der Lende, 1979; 1989). Van de kinderen heeft eveneens 5 tot $10 \%$ ten minste hulp van de huisarts nodig (Van Mölken et al., 1989). Het percentage patiënten đat specialistische hulp behoeft bedraagt ruim $2 \%$, heigeen, rekening houdend met de toename van de Nederlandse bevolking sedert het betreffende epidemiologische onderzoek, neerkomt op minimaal 300.000 patiènten ( Van der Lende, 1989). Wanneer onderscheid wordt gemaakt naar diagnosecategorie en leeftijj, blijk: dat relatief veel kinderen (0-15 jaar), met name jongens, astma hebben. In de leeftijdscategorie van 20 tot 50 jaar komt astma meer voor bij vrouwen dan bij mannen, terwijl chronische bronchitis thans nog het meest voorkomt bij mannen boven de 50 jaar. Emfyseem treedt, zoals reeds opgemerkt, hoofdzakelijk bij ouderen op en eveneens meer bij mannen dan bij vrouwen.

Cara staat in Nederland op de derde plaats in de rij van primaire doodsoorzaken (CBS, 1987). Bovendien is $20 \%$ van het werk- en schoolverzuim een direct gevolg van de onder 
Cara ressorterende aandoeningen. Van der Lende et al. (1975) schatte het werkverzuim op 7 miljoen werkdagen per jaar, hetgeen neerkomt op meer dan 20.000 manjaren. Een aanzienlijk deel van het voortijdig uittreden uit het arbeidsproces blijkt door aandoeningen van de luchtwegen te worden veroorzaakt. Voor wat betreft het schoolverzuim is $20 \%$ hiervan een gevolg van Cara (Lako, 1983: Rijcken et al., 1988).

De medische consumptie in samenhang met Cara is aanzienlijk. De geschatte kosten in verband met de meer dan 31.000 ziekenhuisopnamen ten gevolge van Cara bedroegen in 1985165 miljoen gulden, ofwel $1.5 \%$ van de totale ziektekosten. De gemiddelde zickenhuisopname voor Cara duun 18 dagen, terwijl de gemiddelde verpleegduur in Nederland 7 dagen is. De kosten voor medicamenteuze Cara-therapie stijgen snel. Meer dan 7\% van de huidige extramurale geneesmiddelenomzet in Nederland heef betrekking op Cara (Raad voor Gezondheids Onderzoek, 1991).

Uit genoemde feiten blijkt, dat Cara een aanzienlijk gezondheidsprobleem is met grote financieel-economische consequenties.

\subsection{Verschillende niveaus van Cara-zorgverlening binnen de Nederlandse gezondheidszorg}

Cara-zorgverlening vindt in Nederland op verschillende niveaus plaats. In figuur 1.2. staan deze niveaus weergegeven. De in de figuur opgenomen percentages vertegenwoordigen een schatting van het aantal patiènten dat momenteel voor behandeling in het betreffende niveau in aanmerking komt. Deze schatting is ontleend aan uitspraken die hierover zijn gedaan door het College voor Ziekenhuisvoorzieningen (1990). De piramide is naar een idee van Kaptein et al. (1988a). Maillé et al. (1991) merken op, dat naarmate het zorgniveau hoger wordt, het aantal patiēnten afneemt. Echter, de intensiteit van de behandeling neemt toe, evenals de diversiteit van de behandelaars die daarbij zijn betrokken en die tezamen het multidisciplinair team vomen.

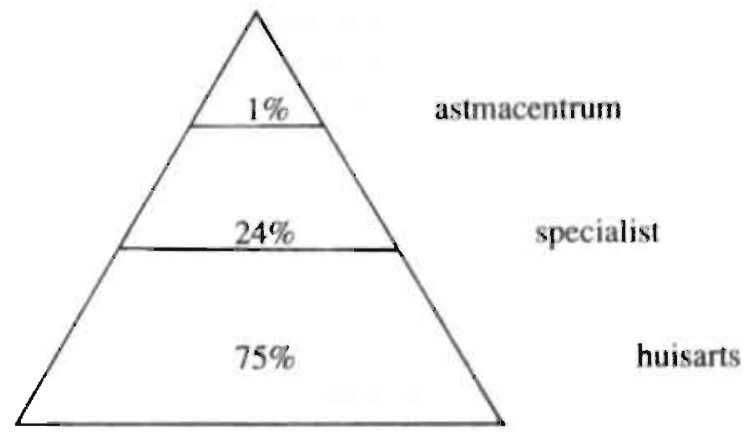

figuur 1.1. Niveaus van zorgverlening ten behoeve van Cara-patiënten

Kaptein et al. (1988a) onderscheiden bovendien de 'onbekende patiënt', waarmee zij doelen op de groep van Cara-patiënten die niet onder medische behandeling staat. Slechis én derde van de patiënten die aan Cara lijdı is bij đe huisarts als zodanig bekend (Kaptein et al., 1987a). Onderdiagnostisering door de huisarts lijkt hiervan de belangrijkste oorzaak (Anderson et al. 1983; Kaptein et al., 1987b; Speight et al., 1983). 
Het consult van de huisarts richt zich op diagnostiek en behandeling van de patiènt met minder emstige Cara-klachten. Waar nodig wordt bij de behandeling de hulp ingeroepen van eerste-lijnsvoorzieningen, zoals district- en wijkverpleegkundigen, maatschappelijk werk, en fysiotherapeuten. De long- of kinderarts kan worden geconsulteerd voor diagnostiek en voor advies over een in te stellen behandeling. De behandeling door de huisarts is primair gericht op het helpen voorkómen van overmatige blootstelling aan allergische en aspecifieke prikkels. Indien dit niet mogelijk is, of onvoldoende effect blijkt te hebben, moeten de klachten medicamenteus worden bestreden. Daarbij zijn de $\beta_{2}$-sympaticomimetica als eerste medicijn aangewezen. Indien dit tot onvoldoende afname van klachten leidt, wordt anti-inflammatoire therapie geadviseerd. Hiertoe worden cromoglycaat of inhalatie- en orale corticosteroïden voorgeschreven. Vooral bij langdurig gebruik van hoge doseringen orale corticosteroïden zijn nadelige bijverschijnselen te verwachten (Van Schayck et al., 1991). Met de komst van de inhalatiecorticosteroìden is het zelden noodzakelijk om permanent te behandelen met orale corticosteroìden. Inhalatiecorticosteroiden worden momenteel op ruime schaal en in toenemende mate gebruikt en hebben in gebruikelijke doses, in tegenstelling tot de orale toedieningsvorm, nauwelijks bijwerkingen.

Naast het verschaffen van medicamenteuze therapie is het geven van voorlichting een belangrijke taak van de huisarts. Deze dient er in de eerste plaats op gericht te zijn dat de patiènt zich realiseert dat hij Cara heeft. Inzicht hierin is een belangrijke voorwaarde voor een adequate omgang met de aandoening (Kaptein, 1988c). De voorlichting is verder gericht op uitleg over mechanismen en uitlokkende factoren van de luchtwegobstructie en op het doel en de werking van medicijnen. Tevens wordt aandacht gevestigd op een adequate zelfzorg, door de patiènt te leren wat te doen bij een aanval van kortademigheid, hoe uitlokkende factoren kunnen worden gemeden, terwijl tevens adviezen worden gegeven het roken te stoppen en voldoende lichaamsbeweging in acht te nemen. Een belangrijk aandachtspunt binnen de voorlichting is verder het voorkómen dat de patiënt de medicijnen niet of niel goed inneemt. In het algemeen blijkt de therapietrouw bij Cara-patiënten laag te zijn. Verschillende onderzoeken geven percentages tussen $6 \%$ en $67 \%$ (Cluss et al., 1985). Voorlichting binnen een goede arts-patiëntcommunicatie blijkt in deze gebrekkige therapietrouw verbetering te kunnen brengen (LeBaron et al., 1985).

Of behandeling moet plaatsvinden door de huisarts of door de longspecialist is in het algemeen afhankelijk van de einst van de aandoening. In ieder geval vindt verwijzing naar de specialisi plaats als de behandeling van de huisarts niet tot het gewenste effect leidt. Behandeling door een specialist vindt plaats in een ziekenhuis en kan zowel van poliklinische als klinische aard zijn. Wanneer sprake is van een opname verblijft de patiënt gedurende korte of langere tijd in het ziekenhuis. Meestal betreft het een behandeling voor acute problematiek of voor complicaties van de aandoening. In veel gevallen wordt de patiënt door zowel de longspecialist als de huisarts gezien. Het gaat hierbij meestal om patiënten die veel zorg behoeven.

Verwijzing naar een derdeijins voorziening vindt plaats indien de behandeling in een ziekenhuis onvoldoende effect heeft of indien de aandoening emstig wordt gecompliceerd en daardoor bemoeilijkı door psychologische en sociale problemen die op hun beurt de aandoening in stand kunnen houden. Onder een derdelijns voorziening worden een astmacentrum of een kliniek voor longrevalidatie verstaan. Voor een nadere beschrijving van dit behandelniveau wordt verwezen naar hoofdstuk 2. 
Hoewel er veelal van wordt uitgegaan dat vooral de ernst van de aandoening bepalend is voor het niveau waarop de zorg dient plaats te vinden lijkt de keuze tussen een behandeling in een ziekenhuis en een astmacentrum vooral gebaseerd op het al dan niet bestaan van nietsomatische complicaties. Deze worden ook wel uitgedrukt in termen van 'beperkingen' en 'handicaps' (zie voor uitleg van deze termen verderop in dit hoofdstuk).

\subsection{Psychologische en sociale aspecten van Cara}

In deze paragraaf worden enkele in de literatuur beschreven verbanden tussen Cara en psychologische en sociale factoren belicht.

De gedragswetenschappelijke aandacht voor Cara gaat terug tot aan het begin van deze eeuw. In de loop van de decennia nadien hebben verschillende accenten het onderzoek naar de samenhang van Cara met psychologische en sociale kenmerken bepaald. Enkele van de te onderscheiden benaderingen zullen in deze paragraaf worden belicht.

Allereerst worden invalshoeken belicht van waaruit getracht is aan te tonen dat specifieke persoonlijkheidseigenschappen of gedragsfactoren aanleiding vormen voor het ontstaan van astma, of voor het optreden van benauwdheidsaanvallen. De tweede benadering waaraan aandacht wordt gegeven betreft de psychologische (waaronder tevens de neuropsychologische) en de sociale problematiek opgevat als gevolgen van de aandoening. De laatste jaren worden deze gevolgen ook wel aangeduid met de term 'kwaliteit van leven'. Tevens wordt sedert 1980 een classificatiesysteem voor chronische ziekten gehanteerd, waarin de gevolgen van een chronische ziekte worden beschreven in termen van 'stoomis', 'beperking' en 'handicap' (World Health Organization, 1980), Daar deze termen in de revalidatieliteratuur veelvuldig worden gebruikt zullen zij kort aan bod komen.

Ten derde onderscheiden we in de literatuur de benadering die de rol van psychologische kenmerken opvat als determinant van de uitkomst van het medisch handelen. Verschillende theorieën sluiten bij deze determinantbenadering aan, waaronder de zogenaamde 'psychomaintenance'-theorie (Kinsman et al., 1982), theorieèn over 'coping' (Cohen et al. „1979; Folkman, 1992; Lazarus et al., 1984) en theorieën over de relatie tussen sociale steun en het beloop van de aandoening (o.a. Cohen et al., 1985).

\subsubsection{Psychologische en sociale factoren die de aanleiding vormen voor het ontstaan van} (symptomen) van Cara

Binnen de klassieke psychosomatiek werden intrapsychische conflicten beschouwd als factoren die het ontstaan van astma mede bepalen. Deze opvatting werd geïnspireerd door de psychoanalytische theorie en bestudeerde de kenmerken van een voor de aandoening predisponerende persoonlijkheid. De theorie ging ervan uit dat Cara (het gaat vooral ovei astma) voor een belangrijk deel psychogeen van aard is (Alexander et al., 1968; Dekker \& Groen, 1956). Alexander ontwikkelde binnen deze stroming de 'specificiteits-' of 'kemconflicttheorie'. De gedachte achter deze theorie is dat een ziekte niet alleen kan ontstaan op basis van een emotionele conflictsituatie of persoonlijkheidsconstellatie, maar dat bij een bepaalde situatie of constellatie een bepaalde ziekte behoort.

Alexander et al. achten voor de ontwikkeling van een 'psychosomatische ziekte' het samenspel van drie factoren van doorslaggevend belang I. een 'somatische kwetsbaarheid' in de vorm van een aangeboren of in de constitutie gegegeven ziekte, 2. een 'psychologische kwetsbaarheid' in de vorm van een in de (vroege) kindertijd ontwikkelde gevoeligheid voor 
een bepaáld type van conflict en 3. het op latere leeftijd uitbreken van hetzelfde type conflict hetgeen dan de ziekte doet ontstaan (zie Menges, 1986).

Volgens Alexander et al. (1968) ligt aan astma het volgende conflict ten grondslag: 'Het centrale conflict komt voort uit inteme impulsen die de binding van de persoon met de moeder bedreigen. Specifiek is het een conflict over het huilen'. Moeders van astmapatienten zouden daar ambivalent tegenover staan. Het kind wil door huilen contact maken, maar riskeert daardoor tevens verstoting. Astma wordt gezien als de onderdrukte schreeuw om de moeder (Alexander et al., 1968). Genoemde psychologische factoren spelen volgens deze theorie, in interactie met pathofysiologische oorzaken, een rol in het ontstaan van astma. Uit deze stelling werd vervolgens afgeleid dat de symptomen van Cara door middel van psychotherapie, met name psychoanalyse, kunnen worden beïnvloed. Maillé et al. (1991) concluderen op basis van literatuuronderzoek dat deze psychosomatiek-opvatting met betrekking tot Cara nooit door middel van onderzoek werd bevestigd en dat nooit is aangetoond dat de bijbehorende therapeutische interventies tot gezondheidswinst hebben geleid. Deze conclusie komt eveneens naar voren in enkele andere publikaties (Creer, 1978, 1982; Kaptein et al., 1987a; Maes et al., 1987: Vromans, 1990).

De tweede stroming die oorzakelijke verbanden tracht te leggen tussen Cara-symptomen en psychologische en gedragskenmerken was de leertheorie (met de daaruit voortvloeiende gedragstherapeutische interventies). De leertheoretici uit de jaren zestig en zeventig gingen uit van de gedachte dat verschillende emoties een stimulus kunnen vormen voor een benauwdheidsaanval (Levinson, 1979; Luparello et al., 1970; McFadden et al., 1969; McNichol et al. 1973). Gedragsinterventies, zoals relaxatietraining, biofeedback, systematische desensitisatie, en assertiviteitstraining, waren erop gericht deze stimuli onder controle te krijgen, waardoor een benauwdheidsaanval achterwege zou blijven. Daarbij werd tevens verondersteld dat op deze wijze verbeteringen in de longfunctie konden worden bewerkstelligd. Cluss (1986) vatte de literatuur aangaande onderzoeken naar de effecten van deze. interventies samen en concludeerde dat de methodologie van deze onderzoeken nogal eens. tekortkomingen laat zien. Kaptein et al. (1987a) concluderen dat het aanvankelijke optimisme over de effecten van relaxatietechnieken voor Cara-patiënten reeds een tiental jaren sterk is gerelativeerd.

Hierbij dient nog te worden opgemerkt dat interventies uit de gedragstherapie well een toegevoegde waarde kunnen hebben binnen de behandeling van Cara-patiënten. Een voorbeeld hiervan is systematische desensitisatie, een interventie waarbinnen fobische stimuli geleidelijk worden aangeboden, met als doel de patiënt zodanig aan deze stimuli te laten wennen, dat er sprake is van afname van angst en daarmee met het tegengaan van vermijding. Zo kan de angst voor de angst bij benauwdheid tot vermijding van activiteiten en situaties leiden, waardoor inactivatie en isolement kan optreden. Door systematische desensitisatie kan de patiènt worden geholpen deze angst te overwinnen. Ook relaxatie-oefeningen kunnen een toegevoegde waarde hebben. Patiënten wie wordi geleerd zich te ontspannen in situaties, waarbinnen zij voordien geneigd waren in paniek te raken, zijn beter in staat om het hoofd koel te houden en de juiste beslissingen te nemen. Een plotseling opkomende aanval van benauwdheid kan op die manier sneller het hoofd worden geboden. Ten aanzien van de longfunctie zullen deze interventies geen gevolgen hebben. Wel dragen zij bij tot de. toename van coping-vaardigheden. 
Alvorens in te gaan op literatuur over de psychologische en sociale gevolgen van Cara, volgen enkele opmerkingen aangaande het in dit verband de laatste jaren veel gebruikte begrip 'kwaliteit van leven'. Tevens zal een paragraaf worden gewijd aan het classificatiesysteem van chronische ziekten opgesteld door de World Health Organization (1980).

\subsubsection{Kwaliteit van leven}

Sinds de jaren vijftig van deze eeuw leck de betekenis van de infectieziekten teruggedrongen en werd in hoog tempo de heterogene groep van niet-besmettelijke chronische ziekten, zoals hart- en vaatziekten, kanker, diabetes, reumatische aandoeningen en Cara steeds belangrijker. Deze ontwikkeling betekende een aandachtsverschuiving van 'cure' naar 'care'. Daarmee deed het begrip 'kwaliteit van leven' zijn intrede binnen de gezondheidszorg.

Er bestaat nog veel meningsverschil over de definitic van kwaliteit van leven. Feinstein (1987) ziet het ontbreken van overeenstemming over het basale construct dat met kwaliteit van leven wordt aangeduid als één van de voornaamste problemen waarmee het kwaliteitvan-leven-onderzoek te kampen heeft. Door dit gebrek aan eenstemmigheid heeft het concept kwaliteit van leven zich ontwikkeld tot een paraplur waaronder meetinstrumenten schuilgaan, die meten wat de gebruiker er onder wenst te verstaan. Greer (1987) stelt dan ook terecht dat het voor clinici en onderzoekers van het grootste belang is om consensus over de definitie van kwaliteit van leven te ontwikkelen. Bergner (1989) merkt op dat we niet uit de problemen zijn met een algemene definitie. Volgens deze auteur moet wat onder kwaliteit van leven wordt verstaan specifiek voor afzonderlijke ziekten worden gedefinieerd. Voor Cara deden Guyatt et al. (1987a; 1987b) daartoe een poging. Binnen hun onderzoek werden 100 patiènten met Cara geïnterviewd, van wie werd vermoed dat de aandoening een negatief effect had op het dagelijks leven van de patiënt. Uit de interviews kwamen de volgende belangrijke probleemgebieden naar voren: kortademigheid, vermoeidheid en emotionele problematiek, waaronder verwarring, depressie, angst en frustratie. Daarbij bleek de ernst van de benauwdheden slechts zwak gerelateerd aan de problemen van de patiènten.

De laatste jaren staat tevens de kwestie van de operationalisering van het begrip kwaliteit van leven centraal. Een belangrijk signaal is de opkomst van de discussie over algemene versus specifieke meetinstrumenten (Williams, 1989a). In Nederland is inmiddels een ziektespecifieke kwaliteit-van-leven-vragenlijst voor patiënten met Cara beschikbaar (Maillé et al., 1994).

Ondanks het ontbreken van een eenduidige definitie van kwaliteit van leven bestaat er consensus over dat onder het begrip zowel functionele, psychologische, als sociale kenmerken ressorteren (de Haes et al., 1985; van Knippenberg et al., 1988; Maillé et al., 1994; Stuurgroep Toekomstscenario's Gezondheidszorg, 1992).

Verschillende studies hebben kwaliteit van leven als afhankelijke variabele opgevoerd in onderzoek onder Cara-patiënten. Dekker (1993) geeft hiervan een uitgebreid literatuuroverzicht. Schrier et al. (1990) vonden een verschil in kwaliteit van leven tussen astma-patiènten en patiënten met COPD. De laatste groep van patiënten bleek meer beperkt qua dagelijks functioneren dan de astmapopulatie. Vanuit de constatering dat de relatie tussen de somatische gesteldheid en de kwaliteit van leven-variabelen zwak is, bevelen de auteurs aan, naast de medisch-somatische aandacht in de behandeling ook de nodige aandacht te besteden aan psychosociale interventies. 
In een studie van Kaptein et al. (1993) werd de kwaliteit van leven in kaart gebracht van patiënten uit zes Nederlandse poliklinieken voor longziekten. Het betrof 274 patiënten met Cara. De kwaliteit-van-leven-kenmerken (angst, depressie, slaapstoomissen, optimisme, schaamte en activiteiten van het dagelijks leven) bleken meer met de symptomen van Cara te correleren, dan met de longfunctie.

Kwaliteit van leven is een van de aandachtsgebieden waaraan binnen sociaal-wetenschappelijk Cara-onderzoek prioriteit dient te worden gegeven (Maille et al., 1992; McSweeny, 1988). Ook als het gaat om evaluatieonderzoek dienen aspecten van kwaliteit van leven van de patiènt centraal te staan (Raad voor Gezondheidsonderzoek, 1991).

\subsubsection{Stoornis, beperking, handicap}

Door de World Health Organization (1980) werden de begrippen 'stoornis', 'beperking' en 'handicap' gedefinieerd om de gevolgen van een chronische aandoening, waaronder Cara, te kunnen beschrijven. De termen zijn ontleend aan de 'International Classification of Impairment, Disability and Handicap'. Deze classificatie is een aanvulling op de 'Intemational Classification of Diseases' (ICD), een medisch begrippenapparaat waarin het concept 'ziekte' in een codesysteem wordt ondergebracht. De ICD-indeling is voor chronische ziekten niet afdoende gebleken. Immers, door het aanhouden van de ziekte treden restverschijnselen (gevolgen) op die zwaarder gaan wegen. Het ziek-zijn houdt dan niet alleen meer een toestand van 'onwel-zijn' in, maar beīnvloedt ook de uitvoering van taken en het nakomen van verplichtingen. Niet alleen het 'puur medisch lijden', maar ook psychische, sociale en economische verwikkelingen die nauw met de gevolgen van de ziekte zijn verweven gaan een rol spelen. Voor het bredere scala van problemen waarvoor mensen met een chronische aandoening hulp zoeken, welke ten dele buiten het begrip ziekte in engere zin vallen, heeft de ICD geen classificaties. Vandaar dat er sedert 1980 een apart codesysteem bestaat.

De volgende definities worden gegeven (World Health Organization, 1980): een stoornis is iedere afwezigheid of afwijking van een psychologische, fysiologische of anatomische structuur of functie. Een beperking wordi gedefinieerd als iedere vermindering of afwezigheid (ten gevolge van een stoornis) van de mogelijkheid tot een voor de mens normale activiteit zowel wat betreft de wijze als de reikwijdte van de uitvoering. Een handicap wordt gedefinieerd als een nadelige positie van een persoon als gevolg van een stoornis of een beperking, welke de nomale rolvervulling van de betrokkene (gezien leeftijd, geslacht en sociaal culturele achtergrond) beperki of verhindert.

Het enige aangetroffen onderzoek waarbinnen gebruik werd gemaakt van deze begrippen toegepast op Cara-patiënten is dat van Williams et al, (1989b; 1989c), die een poging deden informatie te verkrijgen omtrent de omvang van de stoornis, beperking en handicap van een Cara-populatie. Daartoe interviewden zij 92 patiënten met Cara. Zij vonden een relatief lage negatieve correlatie $(r=-.38 ; p<.001)$ tussen longfunctie en beperkingen, terwijl er een hoge positieve correlatie $(r=.90 ; p<.001)$ bestond tussen dyspnoe en beperkingen. De belangrijkste gebieden binnen de beperkingen en handicaps betroffen huishouding, bewegingsvrijheid, slaap, recreatie en werk. Tevens werden vaak financiële problemen en gevoelens van sociale isolatie gerapporteerd. 
De meest beschreven gevolgen van Cara zijn depressie en angst. De toestand van depressie kan worden beschouwd als een reactie op verliezen die als gevolg van de aandoening door de patiënt worden ervaren. De reactie op verlies kan worden vergeleken met een rouwproces. Dudley vat dit proces als volgt samen: 'Chronically ill respiratory patients experience varied losses. Their positive feelings associated with health are often replaced by fatigue, dyspnea, and reduced exercise tolerance. Knowing that their illness is irreversible may create feelings of hopelessness and fear of losing control in these patients. When their illness progresses, positive self-attitudes often diminish. Independence and pride are lost as patients are forced to retire, change their recreational activities, and rely on others for assistance in performing household tasks or in meeting personal needs such as dressing or bathing. Feelings of inadequacy may result when social roles change' (Dudley et al., 1993). Wise et al. (1988) merken op in plaats van depressie liever te spreken van een aanpassingsstoomis met een neerslachtige stemming, waarbij de aanpassingen aan de aandoening, zoals het gedeeltelijk moeten opgeven van een levensstijl, met emotionele problemen gepaard kan gaan.

Elders merkt Dudley et al. (1973) op dat emstige Cara-patiënten veelal in een 'emotional straitjacket' leven. Er is een toestand ontstaan waarin de patiënt geen uiting meer geeft aan boosheid, blijdschap en andere emoties, omdat iedere emotionele verandering bij de emstiger graden van Cara kan leiden tot een fysiologische decompensatie, hetgeen tot uiting kan komen in het optreden van kortademigheid. Deze angst kan ertoe leiden dat de patiënt een gewoonte ontwikkelt van sociale vermijding. Het zich sociaal terugtrekken kan vervolgens gevoelens van somberheid doen toenemen.

Verschillende auteurs tonen aan dat het symptoom depressic in vergelijking met andere aandoeningen zelfs het meest voorkomt bij Cara (o.a. Gift et al., 1986; Murrell et al., 1983). Zowel McSweeny et al. (1982) als Light et al. (1985) deden onderzoek naar het voorkomen van angst en depressie in een populatie met een matige tot ernstige vorm van Cara. Tevens bepaalden zij of de aanwezigheid van depressie of angst de functionele mogelijkheden van de patiënt, uitgedrukt in de 12-minuten loopafstand, beënvloedde. Het bleek dat $42 \%$ van de patiënten hoog scoorde op de Beck's depressie-test, terwijl slechts $2 \%$ van de patiënten significant hoog, scoorde op angst, gemeten met de State-Trait Anxiety Inventory. De correlatie tussen depressie en angst bleek hoog $(r=81)$, terwijl geen verband kon worden aangetoond tussen het depressie- of angstniveau en de prestatie op de 12-minuten looptest.

Agle et al. (1973) vonden dat patiënten met Cara die tijdens behandeling fysiek verbeterden, ook verbeteringen lieten zien op depressie en angst. Dit zou een bevestiging zijn van de theorie dat depressie en angst het gevolg zijn van de afgenomen functionele mogelijkheden van patiënten met Cara.

McSweeny et al. (1980) gingen de kwaliteit van leven na bij 166 Cara-patiënten die deelnamen aan de 'Noctumal Oxygen Therapy Trial'. Zij onderscheidden vier basisdimensies binnen het begrip kwaliteit van leven: 1. emotioneel functioneren, waaronder stemmingsveranderingen, 2. sociaal functioneren binnen werk, gezin, familie, vrienden en relaties, 3. gedrag, zoals zelfzorgvaardigheden en mobiliteit en 4. mogelijkheden om hobby en recreatieve activiteiten uit te voeren. Het bleek dat de levenskwaliteit van deze patiënten in alle genoemde opzichten te wensen overliet. Er was sprake van depressie, ontevredenheid met het leven in het algemeen en somatische preoccupatie. De patiënten uit de onderzoekspopulatie vertoonden slaapproblemen en konden zich moeilijk ontspannen. Verder werd een 
relatie gevonden tussen genoemde kenmerken en neuropsychologische variabelen, waaruit de auteurs de conclusie trokken dat sommige emotionele effecten het gevolg kunnen zijn van een inadequate zuurstofvoorziening naar het limbische systeem en andere voor het emotionele leven verantwoordelijke delen van de hersenen. Een andere hypothese ten aanzien van de sociaal-emotionele veranderingen is te formuleren in termen van secundaire gevolgen van de beperkingen die met Cara samengaan.

Ook Prigatano et al. (1984) deden onderzoek naar de kwaliteit van leven bij Cara-patiënten. Zij onderzochten 985 patiënten met matige hypoxie en vonden dat deze patiënten een verminderde kwaliteit van leven vertonen in vergelijking met een controlegroep die was gematched op leeftijd, sexe en opleidingsniveau. De mate van psychosociale beperking was duidelijker aanwezig dan de mate van fysieke beperking. Er werden vooral moeilijkheden geregistreerd in sociale interactie en vrijetijdsbesteding. De kwaliteit-van-levenkenmerken hielden verband met opleidingsniveau, neuropsychologische en emotionele kenmerken, stemmingstoestand, longfunctie $\left(\mathrm{FEV}_{1}\right)$ en inspanningsmogelijkheden. De auteurs concluderen daarom, dat fysieke en psychosociale kenmerken van kwaliteit van leven bij patiënten met Cara door verschillende variabelen worden beïnvloed. Angst en depressie voorspelden de kwaliteit van leven (gemeten met de Sickness Impact Profile) beter dan fysiologische parameters al $\mathrm{FEV}_{1}, \mathrm{PaO}_{2}, \mathrm{PaCO}_{2}$ en inspanningstolerantie.

Lester (1973) constateerde na afname van de Minnesota Multiphasic Personality Inventory (MMPI) dat Cara-patiēnten op de schalen die hypochondrie, depressie en hysterie meten significant boven de normwaarden scoorden. Tevens beschrijft de auteur dat patiënten met ernstige vormen van Cara als gevolg van afgenomen mobiliteit veelal in een beperkte 'life space' terechtkomen waardoor sociaal isolement optreedt.

Yellowlees et al. (1988; 1987a) constateerden dat patiënten met ernstig astma hogere dan normale waarden op psychiatrische kenmerken vertonen. De meest gestelde diagnoses hadden betrekking op de angststoomissen, terwijl ook sociaal isolement werd aangetroffen. Elders beschrijft dezelfde auteur (Yellowlees et al., 1987b) dat conventionele psychiatrische behandelingsvormen (waaronder psychofarmaca) met succes kunnen worden ingezet ten behoeve van de behandeling van Cara-patiënten en de verbetering van hun kwaliteit van leven.

Agle et al. (1977) kwamen op basis van testonderzoek en klinische interviews tot de conclusie dat angst, depressie, vermoeidheid en somatische preoccupatie symptomen zijn die het gevolg kunnen zijn van Cara. Ook Prigatano et al. (1983) kwamen tot deze conclusie. DeCencio et al. (1968) vonden in een steekproef van 43 Cara-patiënten (in het emfyseemstadium), in vergelijking met 'normalen', hogere scores op negen van de tien MMPI-schalen (vooral depressie, hysterie, hypochondrie en psychasthenie).

Cassileth et al. (1984) onderzochten 758 patiënten, lijdend aan een chronische ziekte. Zij concludeerden dat voomamelijk de emst van de aandoening en de daaruit voortkomende 'disability' en niel de aard van de aandoening correleerde met psychologische problemen. Dat wil zeggen dat tussen de ziekten onderling geen significante verschillen werden gevonden in prevalentie van psychologische problematiek. De Haes (1988) brengt naar voren dat vooral de subjectieve beleving, de prognose en de zwaarte van de behandeling belangrijke variabelen zijn waarvan psychosociale effecten te verwachten zijn, en niet de specifieke aandoening zelf. Cassileth et al. (1984) merken verder op dat neuropsychologische stoomissen vanwege chronische kortademigheid wèl specifiek kunnen zijn voor Cara. Kortademigheid zou tot gevolg kunnen hebben dat er problemen ontstaan in de visueel-ruimtelijke integratie. 
Ook andere auteurs benadrukken het verband tussen Cara en neurocognitieve kenmerken. Neuropsychologisch onderzoek wordt bij Cara-patiènten verricht teneinde na te gaan of er op dat gebied gevolgen zijn van de aandoening. Indien deze worden aangetroffen kan vervolgens worden nagegaan of deze tekorten het gevolg zijn van de verminderde zuurstofspanning (hypoxie) die met Cara kan samengaan of dat andere factoren hiervoor verantwoordelijk zijn. Het antwoord op die vraag kan aanwijzingen geven voor behandeling. Uit onderzoek onder proefpersonen die naar het hooggebergte gaan, waar de zuurstofvermindering vergelijkbaar is met die welke Cara-patiènten kunnen ervaren, blijkt dat bepaalde neurocognitieve functies gevoelig zijn voor zuurstoftekorten. Zo worden verminderde motorische functies en tekorten op het gebied van het geheugen geconstateerd. Deze neuropsychologische veranderingen blijken echter van tijdelijke aard (Clark et al., 1983; Townes et al., 1984). Hombein et al. (1989) beweerden dat wanneer men wordt blootgesteld aan langdurige en herhaalde hypoxie in het hooggebergte, er een permanente verslechtering in neuropsychologisch functioneren kan optreden. Deze toestand is vergelijkbaar met die van Cara-patiēnten. Krop et al. (1973) vonden dat patiēnten die een lage zuurstofspanning hadden, slechtere scores op neuropsychologische tests hadden dan de controlegroep. Het betrof voomamelijk de visuomotorische functies en de snelheid van eenvoudige motorische bewegingen en het geheugen. $\mathrm{Na}$ voortdurende toediening van zuurstof verbeterde deze groep op de gemeten neuropsychologische functies. Het gevolg zou bovendien zijn dat deze patiènten eveneens verbeterden op andere psychologische variabelen: zij waren onafhankelijker, minder bezorgd over de somatische symptomen en beter in staat om met emotionele stress om te gaan. De resultaten van dit onderzoek zouden de gedachte bevestigen dat zuurstoftekort zowel het cognitieve als emotionele leven nadelig beinvloedt. Ook Fix et al.(1982) kwamen tot de conclusie dat een chronische hypoxie bij Cara-patiènten kan leiden tot veranderd of verminderd neuropsychologisch functioneren. Huppert (1982) toonde aan dat een matige hypoxie kan leiden tot geheugenverslechtering, terwijl een emstiger vorm ervan kan leiden tot afname van het abstractievermogen, complexe visuomotorische functies, eenvoudige motorische vaardigheden en aandacht. Fishman et al. (1971) schreven psychische klachten als depressie en daarmee samenhangende somatische preoccupatie toe aan chronische vermindering van zuurstofspanning, waaruit cerebrale tekorten zouden kunnen voortvloeien. Prigatano et al. (1983) onderzochten de neuropsychologische functies bij Carapatiënten met een matige hypoxie. In vergelijking mẹt een controlegroep scoorden deze patiënten slechter op tests die abstract denken, vẹrschillende motorische vaardigheden en geheugen meten. Depressie bleek hiermee niet samen te hangen. Grant el al. (1987) voerden hierop een vervolgonderzoek $\lrcorner$ it. Zij concludeerden dat, naarmate de hypoxie toeneemt, deze neuropsychologische functies verslechteren. Ook bleken leeftijd en opleidingsniveau een rol van betekenis te spelen. Concluderend $k$ an gesteld worden dat sommige negatieve gevolgen. van langdurige kortademigheidsklachten voor een belangrijk deel het directe gevolg kunnen zijin van een verlaagde zuurstofspanning in het bloed, die mogelijk in veel gevallen kunnen worden tegengegaan door deze patiënten extra zuurstof toe te dienen.

Ten slotte verdient in deze paragraaf over psychologische en sociale gevolgen van Cara onderzoek naar de relatie tussen Cara en sexuele problemen aandacht.

Het eerste Nederlandse onderzoek over Cara en sexualiteit dateert uit 1991 (Eekhof et al., 1991). Daarin werd bij 30 patiènten met. COPD, geselecteerd uit vier huisartspraktijken, de sexualiteitsbeleving in kaart gebracht en vergeleken met die van een gezonde populatie. Voor wat betreft de opwindingsfrequentie en de waardering van intimiteit werd een significant lagere score gevonden bij de COPD-patiënten dan bij de controlegroep. Een ruime 
meerderheid van de patiënten gaf tevens aan last te hebben van ademhalingsmoeilijkheden tijdens de geslachtsgemeenschap.

In een recent overzichtsartikel betreffende de literatuur over Cara en sexualiteit van Peersmann-Rijlaarsdam et al. (1994) werd geconcludeerd dat zowel COPD-patiënten als astmapatiënten veel hinder ondervinden van hun ademhalingsklachten bij sexuele activiteiten. Enkele auteurs constateren een positieve samenhang tussen de ernst van de Cara en het seksueel dysfunctioneren, terwijl impotentie de belangrijkste sexuele klacht blijkt te zijn bij mannen met COPD. Als mogelijke oorzaken, ontleend aan de literatuur over sexualiteit bij Cara, worden lichamelijke beperkingen, angst voor toenemen van de benauwdheid, schaamte, verminderd gevoel van eigenwaarde, depressie, negatief lichaamsbeeld en eventuele bijwerkingen van medicijnen genoemd. De onderzoekers concluderen dat de ademhalingsklachten bij Cara tot een aanzienlijke verstoring van het sexueel functioneren kunnen leiden (Peersmann-Rijlaarsdam et al., 1994).

\subsubsection{Psychologische en sociale kenmerken opgevat als determinanten van het beloop van Cara}

In deze paragraaf worden enkele theorieèn besproken die uitgaan van de gedachte dat psychologische en gedragskenmerken, alsmede kenmerken van sociale aard van invloed kunnen zijn op het beloop van Cara. Verschillende auteurs gaan uit van de visie dat de manier waarop de patiènt omgaat met de chronische aandoening mede het beloop bepaalt van deze aandoening en van de medische consumptie die daarmee gepaard gaat (Creer, 1978, 1982; Fix et al., 1982; Gatchel et al., 1983; Kinsman et al., 1982; Stone et al., 1979). Vooral in Denver is tegen deze achtergrond veel onderzoek gedaan bij Cara-patiènten (Kinsman et al., 1973; Kinsman et al., 1974; Staudenmayer et al., 1978).

Allereerst komt in deze paragraaf het van deze 'Denverse school' afkomstige begrip 'psychomaintenance' aan bod. Vervolgens krijgt het begrip 'sociale steun' aandacht.

\subsubsection{Het gezichtspunt van 'psychomaintenance'}

De term psychomaintenance is afkomstig van een groep onderzoekers die in het National Jewish Hospital and Research Center te Denver, in de jaren zeventig en begin jaren tachtig onderzock deden naar de invloed van psychologische factoren op de wijze waarop patiënten met hun Cara omgaan (o.a. Kinsman et al., 1973, 1974, 1980; Dirks, 1978; Staudenmayer et al., 1978). Het vele onderzoek dat van deze onderzoeksgroep afkomstig is, richtte zich bijna alleen op astma. Pas in 1983 werd een tweetal artikelen gepubliceerd dat betrekking had op COPD. Helaas werd op dat moment de subsidiekraan dichtgedraaid, hetgeen het einde betekende van een onderzoekstraditie waarin vanuit deze invalshoek belangwekkend werk is verricht. De term 'psychomaintenance' wordt als volgt omschreven (Kinsman et al. 1982): 'psychomaintenance refers to the psychologic and behavioral perpetuation and exacerbation of physical illness. In this regard, it should be noted that psychomaintenance does not address the etiology of illness as an area of interest but instead focuses on how psychologic and behavioral factors maintain and increase both perceived severity and medical intractability of the illness once it has already developed' (pag. 435). Hoewel, zoals gezegd, de theorie door de onderzoekers alleen werd toegepast op astma en in beperkte mate op COPD, kan deze ongetwijfeld eveneens uitgangspunt zijn voor onderzoek naar andere chronische aandoeningen. 
De theorie en de diagnostick van psychomaintenance is gebaseerd op de assumptie dat elk gedrag dat een ziekte in stand houdt of een juist medisch handelen in de weg staat (bijvoorbeeld een gebrekkige therapietrouw), kan voortkomen uit talrijke en zeer verschillende psychologische achtergronden. De diagnostiek van psychomaintenance richt zich dan ook op verschillende niveaus, namelijk: 1. de persoonlijkheid, 2. de subjectieve ervaring ten opzichte van de aandoening en 3. de attitude aangaande de aandoening en het in behandeling zijn (Kinsman et al., 1982). Verondersteld werd dat elk genoemd psychologisch niveau kan bijdragen aan het ontstaan van ziektegedrag en van invloed is op de 'medical outcome'. Door de Denverse onderzoekers werden specifieke vragenlijsten ontwikkeld, waarmee de attitude en de subjectieve ervaring met betrekking tot de aandoening in kaart kon worden gebracht. Voor het bepalen van persoonlijkheidseigenschappen werd gebruik gemaakt van bestaande lijsten, waaronder de MMPI. Van deze vragenlijst werd vooral gebruik gemaakt van de schaal die 'Panic-fear' meet. Deze schaal meet angst die niet uitsluitend samenhangt met de aandoening. Het betreft de zogenaamde angstdispositie. Voor het in kaart brengen van de subjectieve ervaring van de patiënt met betrekking tot de aandoening, het tweede genoemde diagnostische niveau, werd door de onderzoekers uit de Denverse School de Asthma Symptom Checklist (ASC) ontwikkeld, een lijst bestaande uit 77 heterogene symptomen en ervaringen over een benauwdheidsaanval. De symptomen die in deze lijst worden gemeten kunnen empirisch gezien in de volgende symptoomcategorieèn worden onderverdeeld: angst, gevoelens van irritatie, vermoeidheid, hyperventilatiesymptomen, ademhalingsmoeilijkheden, luchtwegverstopping, zich zorgen maken, woede, eenzaamheid, symptomen van snel ademen en ten slotte, hartkloppingen (Kinsman et al., 1973). Voor het in kaart brengen van het derde genoemde diagnostische niveau, de attitude ten opzichte van de aandoening, werd door de genoemde onderzoeksgroep de Respiratory Illness Opinion Survey (RIOS) ontwikkeld, een lijst die de houding meet ten opzichte van de aandoening en het in behandeling zijn (Staudenmayer et al., 1978). De uitspraken en attituden die in deze lijst zijn opgenomen kunnen empirisch gezien in de volgende clusters worden onderverdeeld: optimisme, negatieve houding ten opzichte van de medische staf, de mate waarin de patiënt zich bewust is van de lichaamssignalen die tot een aanval leiden, exteme controle en psychologisch stigma/schaamte.

Onderzoek van de Denverse school richtte zich onder andere op de verbanden lussen genoernde psychologische variabelen en medische consumptie (zoals de intensiteit van de voorgeschreven medicatie, de opnameduur en de kans op heropname).

Kinsinan et al. (1973) onderzochten het verband tussen de score op de subschaal 'angst bij benauwdheid" van de ASC (de zogenaamde toestands-angst) en de hoeveelheid medicatie die door de arts werd voorgeschreven na ontslag uit het ziekenhuis. Patiënten met een lage score op deze schaal (weinig toestands-angst) bleken bij ontslag minder intensieve medicatie voorgeschreven te krijgen dan patiënten met een hoge. score op deze schaal. De gevonden relatie bleek onafhankelijk van de longfunctie tijdens ziekenhuisopname, onathankelijk van de duur en de debuutleeftijd van de aandoening en onafhankelijk van sexe en leeftijd. Later vonden Kinsman et al. (1977) tevens een positief verband tussen angst (zowel toestandsangst als angstdispositie) en de lengte van ziekenhuisopnamen in verband met Cara en met de kans op een heropname.

Dirks et al. (1977) onderzochten het verband tussen angstdispositie, opgevat als een persoonlijkheidskenmerk (trait-anxiety), en de duur van de ziekenhuisopnamen in veriband met Cara. $\mathrm{Zij}$ vonden een significant positieve relatie tussen de angstdispositie-score, gemeten met de MMPI-PF-schaal en het aantal dagen dat de patiënt in het ziekenhuis moest verblij- 
ven. Ten aanzien van heropnamen werd een curvilineaire relatie gevonden tussen de mate van angst en het aantal heropnamen: patiënten met een lage en een hoge angstscore moesten gemiddeld vaker worden heropgenomen dan patiènten met een gemiddelde angstscore. Ook werd een significant positieve relatie aangetroffen tussen angstdispositie en intensiteit van de voorgeschreven medicatie (bijvoorbeeld corticosteroïden).

Het onderzoek naar de 'psychomaintenance' betrof in de periode van 1970 tot 1982 alleen patiénten mei astma. Vervolgens werd door de onderzoekers in Denver ook aandacht besteed aan patiënten met COPD. Helaas werd de onderzoeksgroep kort daarna ontslagen. Het ligt in de lijn van de verwachting dat wanneer de onderzoekers waren voortgegaan op de ingeslagen weg, er nog een ruim aantal artikelen zou zijn gepubliceerd op het vlak van de psychomaintenance met betrekking tot COPD, terwijl ook de toepassing van het begrip op andere chronische aandoeningen voor de hand lag (Kinsman et al., 1982).

In ons land verrichtte Kaptein replicatie-onderzoek met betrekking tot enkele onderdelen van het Denverse onderzoek. Onder 40 klinische en 51 poliklinische patiënten met astma vond hij dat de opnameduur van patiënten die in een ziekenhuis werđen opgenomen vanwege Cara, significant correleerde met angst bij benauwdheid en met schaamte (respectievelijk maten voor de subjectieve ervaring met betrekking tot symptomen van Cara en attitude ten aanzien van het in behandeling zijn). Verder vond hij dat patiënten die bij ontslag corticosteroïden kregen voorgeschreven, significant hoger scoorden op de schaal die schaamte meet, dan patiënten aan wie deze medicatie niet werd voorgeschreven. Patiènten đie een relatief snelle heropname in het ziekenhuis moesten ondergaan scoorden significant hoger op de schalen die angstdispositie, angst bij benauwdheid en schaamte meten. Deze verbanden bleken onafhankelijk van de emst van het astma (Kaptein, 1982).

Bovenstaande onderzoeken zijn voorbeelden van het type van onderzoek dat vanuit de optiek van de psychomaintenance-opvatting werd verricht. De resultaten hebben een belangrijke bijdrage geleverd aan de gedachtenvorming aangaande de relatie tussen psychologische en gedragsfactoren enerzijds en 'medical outcome' bij Cara anderzijds. De conclusie van de gegevens uil deze onderzoeken is dat de gedragsstijl van deze patiënten een belangrijke invloed kan hebben op het totale klinische beeld van de Cara-problematiek. Het kan de ernst van de aandoening vergroten, wat kan leiden tot de behoefte aan een intensievere behandeling dan op basis van de objectieve somatische toestand allén, nodig zou zijn. Op dit terrein kunnen gedragswetenschappelijke disciplines een positieve bijdrage leveren aan de behandeling van Cara-patienten. Immers, gedragswetenschapers kunnen zich richten op het opheffen van de psychologische en sociale kenmerken die de emst van de aandoening in stand houden.

\subsubsection{Het concept sociale steun}

Het concept sociale steun krijgt het laatste decennium in toenemende mate aandacht van onderzoekers die de verschillende implicaties en determinanten van medical outcome bij chronische aandoeningen tot onderwerp van studie hebben (Appels et al,, 1988; Broadhead et al., 1983; Cobb. 1976; Dunkel-Schetter et al., 1992; Kaplan et al., 1977; Lichtman et al., 1987; Morris et al., 1991).

Uit deze studies blijkt dat sociale steun zowel een buffer-effect alsook een direct gunstig effect kan hebben op gezondheid en op diverse met gezondheid samenhangende variabelen, zoals de psychische toestand (Monroe et al. 1986, Williams et al. 1981), de medische consumptie (Pilisuk et al., 1987; Broadhead et al., 1989; Fishman, 1994), algemene morbidi- 
teit (Blake et al., 1986: McKay et al., 1985) en mortaliteit (Appels et al., 1988; Ruberman et al., 1984). De gedachte achter het concept sociale steun is dat sociale relaties verondersteld worden een heilzame uitwerking op de lichamelijke en psychische gezondheid uit te oefenen. In die zin is sociale steun op te vatten als een determinant van gezondheid.

Er wordt wel verband gelegd tussen coping en sociale steun. De Ridder et al. (1994) merken op dat in de gangbare opvatting studies naar coping en die naar sociale steun weliswaar tot twee verschillende onderzoekstradities behoren, maar dat informatie over de wederzijdse invloed van sociale relaties en coping relevant zou kunnen zijn. Ook andere auteurs neigen naar een integratie van de coping- en de sociale steun-theorie (Eckenrode, 1991; Thoits, 1991: Revenson, 1994). Sociale steun kan worden opgevat als een coping-strategie, dat wil zeggen, een bron van coping die in de sociale omgeving beschikbaar is.

Er bestaat een aanzienlijk aantal manieren om sociale steun nader te beschrijven en de werking op de gezondheid te conceptualiseren en operationaliseren (Thoits, 1982; Coyne et al., 1988; Sarason et al., 1990). Wat de verschillende benaderingen met elkaar gemeen hebben is het optimisme over de rol van sociale steun in gezondheidsbevordering en preventie. Verschillende typologieèn van steunend gedrag zijn voorgesteld. Veelal wordt onderscheid gemaakt tussen twee benaderingen: de structurele en de functionele benadering (De Ridder et al., 1994; Barrera et al., 1986; Cohen et al., 1988; Sarason et al., 1990; House et al., 1985; Cohen et al., 1985; Broadhead et al., 1989). Het onderscheid is gelegen in het antwoord op de vraag of sociale steun geconceptualiseerd is in termen van de structuur van een interpersoonlijke relatie of sociaal netwerk (al dan niet een partner hebben, het aantal vrienden en bekenden, lidmaatschap van verenigingen, enz.), of in termen van de functies en kwaliteiten die een relatie of een netwerk dienen (bijvoorbeeld het leveren van affectie en van het gevoel erbij te horen).

De kwaliteit van sociale steun blijkt een krachtiger voorspeller voor gezondheid dan structuur-maten (Surtees, 1980; Blazer, 1982; Broadhead et al., 1989). House et al. (1985) pleiten er daarom voor om in gezondheidsstudies naar sociale steun voomamelijk gericht te zijn op de functionele inhoud van de relaties.

De gezinsrelaties, in casu de relatie met de eigen partner, leveren een belangrijke bron voor sociale steun (Thompson et al., 1992). Partners zijn veelal sterk betrokken bij de beslissingen omtrent de behandeling en de dagelijkse zorg die met de aandoening samenhangt. Bovendien kunnen partners voorzien in continuïteit en veiligheid in een leven met een chronische aandoening, dat op verschillende manieren kan zijn verstoord (Taylor et al., 1988; Woriman et al., 1985). Partners vervullen op deze wijze een belangrijke rol in de coping van patiènten met een chronische ziekte. Er zijn echter enige kanttekeningen te maken over het functionele aspect van sociale steun. Dat patiënten met een chronische ziekte een toegenomen behoefte hebben aan emotionele en zakelijke ondersteuning van de partner is onomstreden (Dunkel-Schetier et al., 1982). Echter, de mogelijkheid om effectieve ondersteuning te leveren kan op verschillende wijzen beperkt blijken. Partners en andere gezinsleden moeten ook leren wanneer zij hulp en steun moeten verlenen en wanneer niet. Immers, te veel steun geven of op de verkeerde tijd steun geven kan negatieve consequenties hebben (Revenson, 1990). Lane et al. (1992) vonden dat een toename van boosheid en frustratie bij Cara-patiënten omtrent de aandoening, tot uitdrukking kwam in negatieve uitlatingen aan het adres van degene die ondersteuning gaf, die op haar of zijn beurt antwoordde met groeiende boosheid en afnemende steun. Patiënten die zeer veel moeite hebben 
met hun aandoening kunnen daarmee hun directe omgeving ontmoedigen in het geven van sociale ondersteuning (Silver et al., 1990).

In dit hoofdstuk werden enkele relevante thema's met betrekking tot Cara beschreven. Er werden definities en epidemiologische gegevens van Cara gegeven. Vervolgens werden de verschillende behandelniveaus van Cara die er binnen de Nederlandse gezondheidszorg bestaan geschetst. Ten slotte kwamen de gedragswetenschappelijke aspecten van de aandoening aan bod.

Het vervolg van de in dit hoofdstuk beschreven gedachtenontwikkeling is een specifieke aanpak voor patiënten met Cara, de longrevalidatie. In het volgende hoofdstuk worden aspecten van longrevalidatie, waarover, binnen het onderzoek waarover in dit proefschrift verslag wordt gedaan, evaluatiestudie heeft plaatsgevonden. 
Longrevalidatie wordt de laatste 25 jaar in toenemende mate ingezet als behandelvorm ten behoeve van Cara-patiènten. De meest aangetoonde effecten van longrevalidatie zijn een verbeterde inspanningstolerantic, verbeteringen in het uitvoeren van algemene dagelijkse levensverrichtingen, afname van angst en depressie en afname van medische consumptie. Deze resultaten worden aangetroffen, zonder dat er sprake is van een verbetering van de longfunctie. Een van de eerste publikaties over longrevalidatie is afkomstig van Petty et al. (1969), de auteurs die een belangrijke bijdrage heeft geleverd aan de wetenschappelijke onderbouwing van deze behandelvorm voor Cara-patiěnten.

In dit hoofdstuk zal allereerst nader worden ingegaan op definitie, doelstelling en inhoud van longrevalidatie. De organisatie van longrevalidatie zoals die in zowel de Nederlandse als de Angelsaksische literatuur wordt voorgesteld, zal worden beschreven. De inhoud en organisatie van longrevalidatie in het algemeen en die van het NAD ten tijde van de uitvoering van het evaluatieonderzoek, worden uiteengezet. Daarbij zal eveneens enige aandacht worden besteed aan het hooggebergte-effect op de luchtwegaandoening. Vervolgens wordt literatuur over de evaluatie van effecten van longrevalidatieprogramma's samengevat.

\subsection{Definitie van longrevalidatie}

In tegenstelling tot de eerdere opvatting dat met Cara-patiënten niet voorzichtig genoeg kan worden omgesprongen, is longrevalidatie vooral een activerende benadering van de Carapatiènt. In 1974 formuleerde het American College of Chest Physicians onder leiding van Pelty, een definitie van longrevalidatie. Deze delinitie, die later ook werd overgenomen door de American Thoracic Society "luidt als volgt: 'Pulmonary rehabilitation may be defined as an art of medical practice in which an individually tailored, multidisciplinary program is formulated, which through accurate diagnosis, therapy, emotional support, and education, stabilizes or reverses both the physio- and psychopathology of pulmonary diseases and attempts to retum the patient to the highest possible functional capacity allowed by his pulmonary handicap and overall life situation' (Petty, 1977).

In Nederland werd door een werkgroep, ingesteld in opdracht van het College voor Ziekenhuisvoorzieningen, eveneens een definitie geformuleerd van longrevalidatie. Deze is min of meer een vertaling van bovenstaande definitie van de American Thoracic Society en luidt als volgt:

'Longrevalidatie is een op het individu toegesneden medische behandeling, gebaseerd op accurate diagnostiek, therapie, psychische en sociale ondersteuning, en educatie. Hel doel van het programma is een stabilisatie of zelfs verbetering van de longaandoening. Er wordt toegewerkt naar optimaal functioneren van de patiënt, rekening houdend met zijn handicap, ten gevolge van de longaandoening, en zijn leefsituatie' (College voor Ziekenhuisvoorzieningen, 1990).

\footnotetext{
' Delen van dit hoofdstuk werden eerder gepubliceerd (Van der Schoot, T.A.W. \& Kaptein, A.A. Lung, 1990. 168, s495-501).
} 


\subsection{Doelstelling en doelgroep}

De doelgroep voor longrevalidatie bestaat uit patiënten waarbij ondanks intensieve behandeling door de huisarts in de eerstelijn en de longspecialist in de tweedelijn geen bevredigende oplossing voor de Cara-problematiek wordt bereikt.

Binnen de terminologie van definitie, doelstellingen en doelgroepen van longrevalidatie wordt veelal gebruikt gemaakt van de door de World Health Organization (1980) in het leven geroepen classificatie-terminologie met betrekking tot chronische aandoeningen: de begrippen 'stoornis, 'beperking' en 'handicap' (voor een nadere beschrijving zie paragraaf 1.4.2.2.).

Deze termen kunnen tevens worden gehanteerd in een beschrijving van categorieën van patiènten die voor een longrevalidatie in aanmerking komen. Door een werkgroep bestaande uit vertegenwoordigers van verschillende astmacentra in Nederland werden de volgende categorieèn genoemd:

- de patiënt die beperkingen en handicaps ervaart, ondanks optimale medische zorg, en ondanks het feit dat deze de aandoening goed kan hanteren.

- de patiënt die zijn aandoening niet goed kan hanteren en daardoor beperkingen en handicaps ervaart, ondanks optimale medische zorg.

- de patiënt met een dermate emstige aandoening dat daardoor onvoldoende controle wordt verkregeni over de stoornis en mede daardoor over de beperkingen en handicaps.

De doelstellingen van longrevalidatie op het niveau van de 'stoomis' worden door dezelfde werkgroep omschreven als het realiseren van een normale, of voor de individuele patiènt maximaal haalbare, luchtwegdoorgankelijkheid. Verder wordt als doel gezien het behandelen. of voorkómen van acute of chronische hinderlijke klachten en symptomen en het voorkómen of veriragen van een mogelijk versneld verlies van longfunctie. Het doel op het niveau van de 'beperkingen' en 'handicaps' is het geheel of gedeeltelijk reduceren van de beperkingen in het dagelijks functioneren van de patiènt, met inbegrip van het lichamelijk inspanningsen prestatievermogen, terwijl tevens het voorkómen van verergering van beperkingen in het dagelijks functioneren tot het doel van longrevalidatie kan worden gerekend. In het laatste geval is het van belang dat de patiënt leert met zijn beperkingen om te gaan. De patiënt moet door de longrevalidatie in staat zijn actiever te worden en onafhankelijk in de zelfzorg. Hierdoor ontstaat de mogelijkheid een actievere rol in te nemen in de samenleving. Tiep (1993) noemt de in tabel 2.1. geformuleerde doelen en verwachtingen van longrevalidatie.

Door verschillende auteurs (o.a. Casaburi, 1993) wordt als belangrijkste doel van longrevalidatie het doorbreken van de neerwaartse spiraal genoemd. Dit geschiedt voomamelijk door patiěnten in staat te stellen een hogere inspanningstolerantie te bereiken. Casaburi (1993, pag. 204) voegt eraan toe dat veel van de voordelen van longrevalidatie op het psychologische vlak liggen: 'Patients become convinced that the shortness of breath they experience is not harmful. They may in fact become desensitized to the sensation of dyspnea. One important way to achieve the psychologic benefit of rehabilitation is through a program of progressive supervised exercise'. Deze gedachte is te vergelijken met die van de systematische desensitisatie voor stimuli waarvoor men angstig is. Door patiënten geleidelijk meer bloot te stellen aan inspanning en kortademigheid en ze de angst hiervoor te helpen overwinnen, zullen ze beter in staat zijn deze inspanningen het hoofd te bieden. Hieruit zullen na verloop 
van tijd belangrijke voordelen op het vlak van de conditie en mogelijkheden tot het verrichten van dagelijkse activiteiten voortvloeien.

Haas et al. (1993) spreken in dit verband van 'the dyspnea spiral' waarmee zij het proces weergeven van vermijding van inspanning op basis van angst voor dyspnoe tijdens lichamelijke inspanning. Deze vermijding van inspanning kan ertoe leiden dat de lichamelijke conditie verder verslechtert hetgeen weer kan leiden tot kortademigheid bij allerlei dagelijkse levensverrichtingen. Dit werkt verdere vermijding van lichamelijke inspanning in de hand. Een belangrijk doel van longrevalidatie is gelegen in het doorbreken van deze spiraal. Hiermee gaat volgens verschillende auteurs een verbeterd gevoel van welbevinden gepaard (zie paragraaf 2.3.).

Tabel 2.1. Doelen en verwachtingen van longrevalidatie ( Bron: Tiep, 1993)

\section{Zich beter voelen}

Minder dyspnoe

Meer vertrouwen in eigen kunnen

Minder angst, depressie en paniek

Minder slapeloosheid

\section{Meer uithoudingsvermogen en kracht}

Van beenspieren

Van de armen

Van de ademhalingsspieren

Zelfcontrole en zelfmanagement

Over dyspnoe

Over de leefsituatie

Sputumevacuatie

Medicatie

Zuurstof

Voeding

Gezinszaken

\author{
Meer aktiviteit \\ Thuis \\ In de gemeenschap \\ Gedurende vrije tijd \\ Op het werk
}

\author{
Groter bereik van functies \\ Zelfzorg \\ Huishouden \\ Boodschappen doen \\ Sexuele activiteit \\ Vrijetijdsbesteding \\ Werk (indien mogelijk)
}

Arts-patiëntcommunicatie

Effectievere artsbezoeken

De verklaring voor het verbeterde welbevinden wordt veelal verondersteld te liggen in het feit dat de patiènt zich weer in staat voelt activiteiten te ondememen, zich daardoor minder afhankelijk voelt van anderen, waardoor onder meer het zelfvertrouwen toeneemt en de stemming verbetert (Cockcroft et al., 1981; Cox et al., 1991; Sinclair et al., 1980). Cox en medewerkers (1988) beschrijven het belang van inspanningstraining als een middel om het fysieke, psychologische en sociale functioneren van patiënten meı Cara te verbeteren. Vooral patiënten met een mildere vorm van Cara, zonder ventilatoire insufficiëntie, profiteren optimaal van deze therapie, aldus de auteurs. Volgens Rosser et al. (198.1) kan inspanningstraining voor een belangrijk deel worden opgevat als een interventie die ertoe leidt dat de angst voor dyspnoe en de daaraan geconditioneerde angst voor inspanning wordt gereduceerd. Inspanningstraining staat haaks op de vermijding van activiteiten. Daarbij blijkt dat de inspanningstraining nog niet altijd samen gaat met cardiopulmonaire trainingseffecten, hetgeen bevestigt dat de geobserveerde verbeteringen in uithoudingsvermogen en dyspnoe 
primair een functie kunnen zijn van psychologische factoren in plaats van fysiologische factoren, aldus de auteur.

Lertzman et al. (1976) noemen hoofdzakelijk een medisch-technisch doel van longrevalidatie, namelijk het voorkómen van een achteruitgang van de onderliggende stoomis en het te boven komen van de functionele stoomissen. Om dit te bereiken is volgens de auteurs fysiotherapie, zuurstoftherapie en psychosociale ondersteuning noodzakelijk. De psychosociale ondersteuning dient zich te richten op de psychologische en emotionele problemen die met de aandoening samenhangen. Deze zouden een belangrijke rol kunnen spelen in de uitkomst van de therapieèn (Agle et al., 1973; Dudley et al., 1973).

Carter (1986), ten slotte, geeft de volgende doelen van longrevalidatie: het verminderen van symptomen, het verminderen van dyspnoe, het doen afnemen van angst en depressie, het bereiken van een toename van algemene dagelijkse levensverrichtingen en het vergroten van de levenskwaliteit. Indien mogelijk, dient te worden bereikt dat de arbeidsplek kan worden behouden, dan wel dat terugkeer in het arbeidsproces mogelijk wordt. Tevens noemt de auteur een reductie van het aantal ziekenhuisopnamen als doel van longrevalidatie.

\subsection{De inhoud en organisatie van longrevalidatie in het algemeen en die van het NAD in het bijzonder}

Verschillende auteurs hebben de structuur en organisatie van longrevalidatieprogramma's beschreven (o.a. Cockcroft, 1988; Decramer, 1992; Folgering et al., 1991; Hodgkin, 1986, 1990; Lerizman et al., 1976; Make, 1986; Miller, 1967; Tiep, 1993). Behoudens accentverschillen komi uit deze pubiikaties over het algemeen een eenduidig beeld naar voren betreffende de verschillende onderdelen waaruit een longrevalidatieprogramma zou kunnen bestaan.

In het revalidatieproces werken verschillende disciplines samen om de gestelde revalidatiedoelen te realiseren. Een belangrijke meerwaarde van deze werkwijze is gelegen in de onderlinge afstemming van de diverse disciplines op regelmatige tijdstippen tijdens het revalidatieproces. Door deze multidisciplinaire afstemming kan ook de noodzakelijke samenhang in het revalidatieproces worden bewerkstelligd.

Een longrevalidatieteam bestaat veelal uit de volgende disciplines: een longarts, als eindverantwoordelijke van het revalidatieproces, een verpleegkundige, een fysiotherapeut, een klinisch psycholoog, een sociotherapeut/groepsbegeleider, een bewegingstherapeut, een creatief therapeut, een matschappelijk werker, een diëtist en medewerkers die betrokken zijn bij (om)scholingsactiviteiten.

Het NAD bestaat sedert 1897. Aanvankelijk werden er in het toenmalige Nederlansche Sanatorium' alleen tuberculose-patiènten verpleegd. Omstreeks het jaar 1950 kwamen er medicijnen in de handel waarmee tuberculose in de meeste gevallen genezen kon worden. De traditionele geneeswijze voor tbc-patiënten, de ligkuur, verdwijnt op de achtergrond. Een opname in het hooggebergte is dan nog maar voor een beperkt aantal patiènten noodzakelijk. Veel sanatoria in Nederland sluiten hun deuren. De opnamecapaciteit van het Nederlandsch Sanatorium in Davos moet worden teruggebracht van 330 naar 200 patiënten. Er werd nagedacht over een andere doelgroep. Aangezien bleek dat steeds meer mensen in Nederland aan astma lijden en dat verondersteld werd dat een verblijf in het hooggebergte voor de ernstige astmapatiěnten heilzaam was, werd in 1957 overgegaan op de behandeling van deze doelgroep. De behandeling van patiënten met astma, en later ook chronische bronchitis en 
longemfyseem was fundamenteel anders dan die van tuberculose: heractiveren, in plaats van rusten. Later is men daarvoor het begrip Tongrevalidatie ' gaan gebruiken.

Een mogelijk ondersteunend aspect van de longrevalidatie in het NAD is het verblijf in het hooggebergte. Immers, hoogebergte gaat gepaard met klimatologische omstandigheden die voor een aantal Cara-patiënten gunstig kunnen zijn. Voor de emstige vormen van COPD bestaat echter een contra-indicatie voor een verblijf in het hooggebergte. De mogelijke voordelen van een behandeling in het hooggebergte zijn een geringere mate van luchtverontreiniging dan op zeeniveau en een stabiel weertype. Bovendien wordt wel als belangrijke factor van het hooggebergteklimaat de gunstige invloed van de afwezigheid van huisstofallergenen beschouwd (o.a. Zuidema, 1970). Ook blijken de concentraties aan pollen en schimmelsporen lager te zijn dan op zeeniveau (o.a. Leuschner et al., 1981). De eventuele effecten van het hooggebergte op Cara hebben betrekking op het verbeteren van de hyperreactiviteit van de luchtwegen (Boner et al., 1985, 1993). Deze factoren zouden een gunstig uitgangspunt kunnen bieden voor longrevalidatie in het hooggebergte. Door het Centraal Beleidsorgaan voor intercollegiale toetsing (CBO) werd recent een rapport opgesteld met als titel: Indicatiestelling voor behandeling van astmapatiènten in het hooggebergte". In dit rapport wordt als indicatiecriterium genoemd 'een uitgesproken allergie en hyperreaktiviteit' (pag. 5). Verder wordt gesteld: Wetenschappelijk onderzoek naar de effecten van behandeling in het hooggebergte is schaars. In publikaties hierover wordt verschillend geoordeeld over de waarde van de behandeling in het hooggebergte in vergelijking met de resultaten va behandeling op zeeniveau. Aan nieuw en goed gefundeerd onderzoek op dit gebied bestaat duidelijke behoefte' (pag. 6).

De opname-procedure voor het NAD bestaat uit een aantal stappen. Alvorens de patient wordt opgenomen in dit centrum vindt nader onderzoek plaats omtrent de geschiktheid voor een longrevalidatie in het hooggebergte. Nadat de arts in Nederland en de arts in het NAD schriftelijk en telefonisch overleg hebben omtrent de mogelijkheden van behandeling in het NAD en daarover een voorlopige overeenstemming hebben bereikı, wordt de maatschappelijk werker verbonden aan het bureau in Nederland ingeschakeld, om een nadere intake uit te voeren. Hierin worden vanuit het perspectief van de patiënt de ziektegeschiedenis, de mogelijkheden, beperkingen en de gezins- en familieomstandigheden in kaari gebracht. Tevens worden de doelen geïnventariseerd die de patiënt bij een opname in het NAD voor ogen heeft. Deze doelen worden als zeer belangrijk aangemerkt, aangezien ze informatie geven over de motivatie van de patiënt voor behandeling. Het resultaat van de intake wordi met het opnameteam van het NAD besproken. Op basis van de medische indicatiecriteria en de resultaten uit de intake komt de beslissing over een opname in het NAD tot stand. Contra-indicaties zijn een te lage zuurstofspanning in het bloed, risico's voor het functioneren voor het hart en te weinig of geen motivatie voor een eigen actieve inbreng in het revalidatieproces. De rokende patiënt wordt niet van opname uitgesloten. In het astmacentrum en de directe omgeving hiervan bestaat een rookverbod.

Driewekelijks vindt er een opname plaats. Meestal worden ongeveer acht patiënten tegelijk opgenomen, die tijdens hun reis van Nederland naar Davos worden begeleid door verpleegkundigen en soms door een arts. In het NAD aangekomen wordt elke patiënt ontvangen door stafleden en door de patiëntengroep waarin hij of zij een belangrijk deel van het revalidatieproces zal gaan doormaken.

De patiènt wordt binnen de eerste uren van opname door de longarts gezien. 
De longarts is verantwoordelijk voor de medische zorg en het 'eindprodukt' van de longrevalidatie. Het doel van de medische zorg binnen de multidisciplinaire longrevalidatiebehandeling is gericht op het beïnvloeden van de pulmonale klachten en de daaruit voortvloeiende somatische problemen op de korte en de lange termijn. Centraal staat het verminderen, respectievelijk opheffen van de bronchusobstructie. De longarts bespreekt met de patiẻnt niet alleen de diagnose, prognose en de voortgang van de behandeling, er wordt ook bijzondere aandacht besteed aan de medicamenteuze behandeling. Het benadrukken van het belang van onderhoudsdoseringen en het opstellen en bespreken en waar mogelijk toetsen van het crisisplan, zijn steeds terugkerende thema's. Voor de behandeling van luchtwegobstructies zijn luchtwegverwijders van groot belang. Verschillende medicijnen worden voor dit doel aangewend. Aërosol bronchusverwijders vormen in dit verband een integraal onderdeel van alle behandelprogramma's voor Cara, terwijl een groot aantal patiënten dat voor longrevalidatie in het NAD in aanmerking komt, tevens orale corticosteroïden krijgt voorgeschreven.

De verpleegkundige is intensief bij de behandeling betrokken. Vanuit de aard van de patientenpopulatie hebben de verpleegkundigen voornamelijk een signalerende, terugkoppelende en educatieve functie. Hiermee leveren zij een belangrijke bijdrage aan het creëren van voorwaarden, die uiteindelijk tot een verbeterde therapietrouw, goede zelfzorg en goed selfmanagement met betrekking tot de omgang met de aandoening moeten leiden.

De fysiotherapeut is gericht op het aanleren en toepassen van ademhalings- en sputumevacuatietechnieken. Het belangrijkste doel van de ademhalingstechnieken is het helpen van de patiënt om de inspanning van het ademen zoveel mogelijk te verminderen. Het adempatroon dient in eerste instantie een adequate ventilatie te leveren. Dat wil zeggen, een ventilatie die in overeenstemming is met de zuurstofbehoefte, die op zijn beurt afhankelijk is van de werking van de longen en het niveau van fysieke activiteit. Anderzijds verzorgt een adequate ventilatie een koolzuurafgifte die voldoende zuurstofopname mogelijk maakt en het zuurbase-evenwicht ondersteunt (dat wil zeggen: hyperventilatie voorkomt). Om dit te bereiken wordt de patiënt geleerd om zo langzaam en ontspannen mogelijk te ademen, waarbij erop wordt gelet dat de adembeweging zo economisch mogelijk wordt uitgevoerd, waar mogelijk abdominaal (buikademhaling). Een langzaam, ontspannen adempatroon dat als doel heeft om te allen tijde (ook tijdens fysieke inspanning) controle over het ademhalingspatroon te behouden (West et al., 1992). Bijzonder belangrijk hierbij is hei om te leren controle krijgen over de uitademing. Immers, wanneer deze te snel plaatsvindt zal dat leiden tot toegenomen luchiwegweerstand, vanwege een collaps van de luchtwegen. De fysiotherapeut wordt verder betrokken bij patiënten die gehinderd worden door slijm in de luchtwegen. De nadruk hierbij ligt op het aanleren van technieken đie de patiënt zo zelfstandig als mogelijk maken in het verwijderen hiervan uit de luchtwegen. Door training van dergelijke ademhalingstechnieken door de fysiotherapeut ontstaat een efficiënter gebruik van de ademhalingsspieren en wordı de afhankelijkheid van anderen verkleind. Naast deze therapieën is de fysiotherapeut betrokken bij de opzet en uitvoering van inspanningstraining-programma's.

Inspanningstraining wordt vrijwel zonder uitzondering als wezenlijk onderdeel beschouwd van longrevalidatie. Make (1986) stelt dat een inspanningstraining-programma de hoeksteen van longrevalidatie dient te zijn. İmmers, in meerdere publikaties is aangetoond dat inspanningstraining leidt tot verbeteringen van de inspanningscapaciteit bij chronisch obstructieve longaandoeningen (zie ook paragraaf 2.3.). Inspanningstraining werd binnen het NAD ten tijde van het evaluatieonderzoek waarover hier verslag wordt gedaan, vijf dagen per week gedurende tien weken gegeven. Patiënten fietsen en lopen gedurende twintig minuten met 
een hartslag die overeenstemt met $70 \%$ van de maximale zuurstof consumptie. Patiènten met een ernstige vorm van COPD werden van dit programmaonderdeel uitgesloten. Deze patienten werden volgens een individueel aangepast programma getraind. De hartslag werd tegelijkertijd gemeten. Buiten de trainingstijd kon op verschillende manieren gebruik gemaakt worden van begeleide lichamelijke inspanning, zowel in de sportzaal als buiten, op vlak en op geaccidenteerd terrein. Tijdens de behandeling in het NAD werden de patiènten voorbereid op mogelijkheden deze activiteiten thuis voort te zetten.

De rol van de bewegingstherapeut was vooral gelegen in het leren verhogen van het bewegingsplezier, niet alleen in en rond het NAD maar tevens binnen het dagelijks leven in Nederland. Door middel van deze therapievorm werd de patiēnt in de gelegenheid gesteld allerlei bewegings- en inspanningsmogelijkheden te gaan ontdekken. Doordat dit veelal in groepsverband plaatsvond kon de patiènt zich temidden van lotgenoten aangemoedigd voelen en zich laten inspireren tot het vinden van nieuwe bewegingsmogelijkheden. Tevens werden de patiênten gestimuleerd lid te worden van een sportclub of zich aan te sluiten bij één van de regionale sportmogelijkheden voor Cara-patiènten.

Op zoek gaan naar nieuwe hobby's en activiteiten gebeurde onder leiding van de creatieve therapeut. In groepsverband werd gewerkt met materialen als metaal, hout, verf en wol, terwijl tevens activiteiten in de vorm van projecten met gebruikmaking van onder andere video en fotografie werden gestimuleerd.

Een belangrijk, doch minder aan één discipline gebonden onderdeel binnen het longrevalidatieproces van het NAD was wat in de Angelsaksische literatuur bekend staat onder de term 'patient education' en in Nederland veelal onder de term 'educatie' of 'gezondheidsvoor. lichting en -opvoeding' (GVO). Patièntenvoorlichting heeft in de jaren tachtig een steeds belangrijker plaats ingenomen bij het bevorderen van gezondheid (Damoiseaux et al., 1988). De longarts, verpleegkundige, fysiotherapeut en psycholoog, waren de directe uitvoerders van GVO, terwijl ook de andere disciplines de inhoud en principes die hieraan ten grondsiag liggen uitdroegen jegens de patiënt. De achterliggende gedachte van GVO binnen het behandelproces was dat een goed begrip omtrent de aandoening bijdraagt an een actieve rol van de zijde van de patiënt in de realisering van de doelen van het longrevalidatieprogramma. Het gaat daarbij vooral om het leren begrijpen van het mechanisme van kortademigheid en de specifieke rol van de verschillende aspecten van het behandelprogramma. Bij GVO voor Cara-patiënten wordt onder meer titleg gegeven over het mechanisme van de luchtwegobstructie en wordt inzicht gegeven in de (medicamenteuze) behandelingsmogelijkheden die worden geboden. Verder worden inhalatietechnieken en het adequat gebruik en onderhoud van inhalatie-apparatutir besproken, aangeleerd en gecontroleerd. Ook het aanleren van technieken voor het bereiken van relaxatie, toegepast op ademhaling en allerlei vormen vaf inspanning en angst bij benauwdheid (Renfroe, 1988), evaluatie van de activiteiten in hei dagelijks leven teneinde energie-verspilling op te sporen en manieren te vinden om ieder aspect van het leven minder inspannend en met meer plezier te laten plaatsvinden, werd onder GVO begrepen. Door middel van verschillende thema-bijeenkomsten werd de patiënt zowel inhoudelijk geïnformeerd alsook begeleid in de richting van de noodzakelijke gedragsveranderingen. Bovenstaande GVO-activiteiten hebben recent geleid tot een voor behandelaars en patiënten bruikbare handleiding (Bij de Vaate et al., 1995).

Een eveneens interdisciplinair onderdeel was het stimuleren van zelfzorg en selfmanagement. Hieronder wordt een veelvoud van interventies verstaan met als doel het creëren van minder afhankelijkheid van de patiënt van de omgeving en van de behandelend arts. Hoe emstiger het ziektebeeld, hoe moeilijker het voor de patiënt is op adequate wijze met de aandoening 
om te gaan. Naarmate de ernst van de aandoening toeneemt, neemt veelal ook de medische consumptie toe. Daarmee raken veel patiënten verstrikt in de veelheid van medicijnen en het ongrijpbare klachtenpatroon. In de literatuur wordt veel aandacht besteed aan selfmanagement, vooral als het gaat om astma. Goodall et al. (1991) omschrijven selfmanagement als 'a set of skilled behaviors engaged in to manage one's own illness'. Belangrijk bij selfmanagement-training is de nadruk op de eigen verantwoordelijkheid, de informatie- en kennisoverdracht over de ziekte (zie ook onder GVO), en het aanleren van een positieve houding ten aanzien van de noodzaak de ziekte te leren hanteren, aldus de auteur. HindiAlexander (1985) geeft de volgende definitie van selfmanagement: 'Selfmanagement is an educational process whereby persons with various health problems learn to work with health care providers to help themselves, thereby enhancing the therapeutic intervention'. Het begrip selfmanagement is essentieel bij de behandeling van chronische ziekten in het algemeen, waarbij het zich actief opstellen van de patiënt een belangrijke voorwaarde is voor behandeling en revalidatie. Selfmanagementtraining vindt zowel plaats bij kinderen (Fireman et al., 1981; Blessing-Moore et al., 1985; Creer, 1983; Creer et al., 1988; Rolnick, 1988), als bij volwassenen met Cara (Green et al., 1977; Creer et al., 1989). Binnen het longrevalidatieprogramma van het NAD was selfmanagementtraining een integraal onderdeel van het behandelprogramma. Doelstellingen en uitgangspunten van de selfmangementbevordering zijn het vermindering van acute klachten, de ontwikkeling van vaardigheden om actief en preventief ten aanzien van de eigen klachten te handelen (juiste medicatie-inname, voorkomen van blootsteiling aan allergenen, adequate lichaamsbeweging, niet roken, etc.), een groter gevoel van beheersing van de eigen symptomen, ook wel het bevorderen van 'selfefficacy' (Bandura, 1977; Devins et al., 1988) en kennisvermeerdering over de ziekte en de behandeling. Deze doelstellingen werden door alle disciplines die betrokken waren bij het longrevalidatieprogramma van het NAD ondersteund. Elke discipline leverde een bijdrage aan het behalen van deze doelstellingen. Daarbij speelde GVO een belangrijke rol.

De klinisch psycholoog. De werkzaamheden van de klinisch psychologen in het NAD liggen zowel op het vlak van psychodiagnostiek als van behandeling. Behandeling vond zowel individueel als in groepsverband plaats.

Psychodiagnostiek. Elke patiënt die in het NAD werd opgenomen kwam voor een aantal intakegesprekken bij de psycholoog. Hierbinnen werd een indruk verkregen van de belangrijkste psychologische problemen die er in samenhang met de aandoening bestonden. In het kader van het onderwoek werd een testbatterij afgenomen, waarvan de resuitaten een bijdrage. leverden aan de individuele behandelplannen. De testbatterij bestond uit een standaardgedeelte (tevens ien behoeve van het evaluatieonderzoek waarover in dit proefschrift wordt gerapporteerd). en uit een gedeelte waarmee diagnostiek van de specifieke problematiek van de patiënt plaatsvond. Hierin was onder andere neuropsychologisch testmateriaal opgenomen.

Voor cen nadere beschrijving van het standaard testgedeelte kan worden verwezen naar hoofdstuk 3. Er werd uitgegaan van drie te onderscheiden assessment-niveaus, te weten: de persoonlijkkheid van de patiënt, de attitude ten opzichte van de aandoening en de subjectieve ervaring ten opzichte van de aandoening.

De psychologische behandeling is voomamelijk gericht op het creèren van betere voorwaarden voor een juiste omgang met de aandoening in het algemeen en deelaspecten daarvan in het bijzonder. In het algemeen kan worden gedacht aan de gunstige beïnvloeding van het ziekiegedrag maar ook aan een psychologische begeleiding van het acceptatieproces samenhangend met de erkenning van de lichamelijke beperkingen samengaat. Verder kan de 
psychologische behandeling een belangrijke rol spelen in het helpen overwinnen van de angst voor bijvoorbeeld lichamelijke inspanning, of het helpen overwinnen van de schaamte voor de aandoening en het onder behandeling zijn. Angst, depressie, schaamte en verongelijktheid zijn bij de NAD-populatie veel voorkomende emoties. Door de psychologen in het NAD wordt gewerkt vanuit de veronderstelling dat deze emoties het gedrag van de patiēnt en daarmee het revalidatieproces en de 'medical outcome' in negatieve zin kunnen beìnvloeden.

De psychologische invalshoek van waaruit met de patiēnt gewerkt wordt kan verschillend zijn. In het NAD wordt, afhankelijk van de instelling en achtergrond van de klinisch psycholoog, vanuit een cognitief-gedragstherapeutische of vanuit een meer psychagogische optiek gewerkt. Eerstgenoemde benadering lijkt zich het meest te lenen voor angstbehandeling en voor het opheffen van hardnekkig vermijdingsgedrag, bijvoorbeeld met betrekking tot lichamelijke inspanning. De psychagogische benadering, die onder meer is gericht op het leven met beperkingen lijkt meer geschikt voor de begeleiding en ondersteuning van het acceptatieproces. Deze bevinding is evenwel niet gebaseerd op onderzoeksfeiten, maar zij berust op klinische ervaring.

Een rechtvaardiging voor een ondersteuning van het revalidatieproces door cognitief-gedragstherapeutische interventies vinden we onder andere binnen de onderzoeksliteratuur, van waaruit de conclusie kan worden getrokken dat de individuele respons op somatische aandoeningen in het algemeen (Sensky, 1990) en op Cara in het bijzonder (Atkins et al. 1984) meer samenhangt met cognitieve factoren dan met variabelen als ernst van de aandoening of ernst van de symptomen. Dit principe werd eerder door Kinsman et al. (1982) beschreven onder de term 'psychomaintenance' (zie ook hoofdstuk 1). Niet alleen de emst van de aandoening, maar ook de wijze waarop de patiênt de aandoening en het onder behandeling zijn waameemt en ervaart heeft invloed op het beloop ervan. Dit komt onder meer tot uitdrukking in het aantal heropnamen en de lengte van opname, het aantal aanvallen en het school- en werkverzuim (o.a. Kaptein, 1982). Intussen werden de angst- en depressiebehandeling al in 1973 beschreven als belangrijke voorwaarden voor het welslagen van longrevalidatie (Agle et al., 1973).

Zowel bij Cara als bij andere aandoeningen blijki cognitieve gedragstherapie tot gezondheidswinst te kunnen leiden. Het leidt tot afname van depressie bij patiènten met multiple sclerose (Larcombe et al., 1984), tof symptoomreductie bij patiënten met 'inflammaiory' bowel disease' (Schwarz et al., 1991), tot afname van psychische klachten bij patiènten met kanker (Tarrier et al., 1984; Skinner et al., 1990), tol reductie van hoofdpijnklachten bij patiënten met migraine (Richardson, 1989) en tot vermindering van ḱlachten bij patiënten met atopisch eczeem (Goldstein, 1990). Aan de hand van de beschrijving van een onderzoek van Atkins et al. (1984) en van Maes et al. (1988) zal nu de effectiviteit van cognitieve gedragstherapie bij Cara-patiënten nadei worden belicht.

In een gerandomiseerd, gecontroleerd onderzoek vergeleken Atkins et al. (1984) verschillende methoden om patiënten met COPD aan te moedigen tot lichamelijke inspanning. Zij hanteerden drie experimentele en twee controlegroepen. In de gedragsmodificatiegroep werden patiënten geïnstrueerd zichzelf te belonen voor lichamelijke inspanning. De cognitieve modificatiegroep gebruikte cognitieve herstructurering met als doel de motivatie voor inspanning te vergroten. Dit gebeurde vanuit de aanname dat cognitieve verandering noodzakelijk is om lange termijn gedragsverandering te bewerkstelligen. Patiënten werden in deze cognitieve herstructureringsgroep geïnstrueerd hoe zij hun interne dialoog tijdens stressvolle situaties konden veranderen. In een derde groep werd gedragsmodificatie met cognitieve her- 
structurering gecombineerd. Er werden twee controlegroepen in het onderzoek betrokken. In één ervan kregen de proefpersonen evenveel aandacht als in de experimentele groepen, maar geen behandeling. In de andere groep werden helemaal geen behandeling en aandacht geboden. Resultaten van de zes-maands follow-up tonen dat de gecombineerde cognitieve en gedragsmodificatiegroep een significant grotere afstand liep dan de groepen waarin alleen cognitieve of gedragsmodificatie werd geboden. De patiënten uit alle drie de behandelgroepen legden meer afstand af dan de proefpersonen uit de controlegroepen. Ook inspanningstolerantie nam bij de patiënten uit de behandelgroepen, in vergelijking met die uit de controlegroepen de eerste drie maanden toe. Na zes maanden was deze toename van de inspanningstolerantic niet meer statistisch significant. Echter, het welbevinden bleef voor wat de experimentele groepen betreft gedurende de zes-maands follow-up toenemen, terwijl deze in de controlegroepen afnam. In overeenstemming met resultaten uit ander longrevalidatieeffectonderzoek ondervonden de patiënten geen verbetering van de longfunctie. Dit onderzoek van Atkins en medewerkers toont aan, dat cognitieve en gedragsstrategieèn een belangrijke bijdrage kunnen leveren in het motiveren en het behouden van therapietrouw bij loopprogramma's voor Cara-patiënten.

Een ander voorbeeld van cognitieve gedragstherapie ten behoeve van de behandeling van Cara-patiënten treffen we aan bij onderzoek van Maes et al. (1987), die een cognitief interventieprogramma ontwikkelden om coping-gedrag van astmapatiënten te veranderen teneinde de emotionele gevolgen van de aandoening en de medische consumptie te beïnvloeden. De effecten van het programma werden geïnventariseerd door middel van een pretestposttest control group design. Het programma werd aangeboden aan tien patiènten en hun partners. De auteurs vonden dat patiënten die het programma kregen geboden, minder gepreoccupeerd waren met hun astma en minder emotionele problemen (waaronder angst en boosheid) vertoonden in hun dagelijks leven. Bovendien gebruikten zij minder corticosteroiden.

Zowel het onderzoek van Maes et al. als van Atkins et al. tonen het belang aan van cognitieve gedragstherapeutische technieken binnen de behandeling van patiènten met Cara.

Een individuele cognitieve gedragstherapie kan op verschillende momenten tijdens een opname van start gaan en is voornamelijk gericht op het opbouwen van nieuwe, meer functionele gedachten en opvattingen omtrent de aandoening en de implicaties ervan. Het doel van deze individuele cognitieve gedragstherapie bij Cara-patiënten opgenomen in het NAD is om voldoende voorwarirden te creëren voor een verbeterde omgang met de aandoening en een daarmee samenhangend verbeterd subjectief welbevinden. Als zodanig is deze therapievorm onlosmakelijk verbonden met het totale longrevalidatieproces. Deze behandelvorm is gestructureerd en directief van aard. Er zijn grofweg drie fasen te onderscheiden: de eerste fase van inventarisatie van disfunctionele en functionele assumpties, de tweede fase, waarin veranderingen worden aangebracht in cognities en de derde fase, waarin de cognitieve veranderingen een definitieve weerslag dienen te krijgen in gedrag dat gericht is op een juiste omgang met de aandoening.

Binnen de eerste fase wordt allereerst ruim aandacht besteed aan de veelal noodzakelijke bijstelling van het bestaande beeld dat patiënten hebben van een psycholoog en de behandeling die daar aan de orde kan zijn. Dit is van groot belang voor het welslagen van de behandeling. Enkele in dit verband veel gehoorde disfunctionele opvattingen over behandeling zijn: 'Als ik naar de psycholoog moet zal de dokter wel denken dat er geen lichamelijke oorzaak bestaat voor mijn ziekte' en: 'Mijn dokter zal me wel hebben opgegeven' of: 'Ik word verwezen naar de psycholoog, dat betekent dat de dokter denkı dat ik gek word, of hij vindt mij een lastige patiënt'. 
Om de patiēnt hieromtrent gerust te stellen wordt veelal benadrukt dat het zeker niet de bedoeling is op zoek te gaan naar psychologische oorzaken van de aandoening, maar om samen te achterhalen wat de cognitieve en gedragsfactoren zijn die, naast de symptomen van Cara, het leven met de aandoening kunnen bemoeilijken, dan wel de behandeling ervan in de weg staan. Vervolgens wordt binnen deze eerste fase een inventarisatie gemaakt van cognities die samenhangen met de aandoening, met de emotionele gevolgen ervan en met het feit dat een intensieve behandeling moet worden ondergaan.

In de tweede fase worden de verschillende cognities aan veranderingstechnieken blootgesteld. Een hierbij veel gehanteerde techniek is de zogenaamde socratische methode. De vragen die binnen deze methode worden gesteld dienen ertoe de patiènt zich bewust te laten worden van de gedachten die bij hem of haar een rol spelen, deze gedachten op cognitieve vervorming te onderzoeken en ze te vervangen door meer adequate gedachten (0.a. Beck et al., 1985), Belangrijk is dat deze tweede fase leidt tot de motivatie om nieuwe gedragingen te beproeven en adequate gedragingen vast te houden. In de derde fase worden gedragingen uitgevoerd, die voorheen als gevolg van de disfunctionele cognities werden vermeden. Dit geschiedt aanvankelijk onder begeleiding, later zelfstandig. Veel gebezigde disfunctionele cognities blijken de volgende:

- ik mag me niet inspannen, anders word ik benauwd

- als ik met anderen op stap ga ben ik diegenen tot last vanwege mijn benauwdheden

- nu ik weet dat ik emfyseem heb is er voor mij in het leven niets meer te beleven

- mensen denken dat ik anders ben omdat ik ademhalingsmoeilijkheden heb

- wanneer je eenmaal in een ziekenhuis gelegen hebt, behandelen mensen je anders dan daarvoor

- al's je ademhalingsmoeilijkheden hebt, denken andere mensen dat je geestelijk een kneusje bent en tel je niet echt meer mee

- mensen geven meer om je wanneer je gezond bent

- opgenomen worden in een ziekenhuis betekent in het algemeen een stap op weg naar iets ergers

- ik. kan mijn medicijnen onmogelijk in het zicht van anderen innemen, zij zullen me uitlachen of denken dat ik me aanstel

- als je teveel aandacht aan je aandoening schenkt toon je niet dat je sterk bent en laat je je kennen

- niemand mag aan me zien dat ik het soms moeilijk heb met ademen, ze kunnen dan denken dat ik hulp nodig heb

Enkele van bovenstaande omschrijvingen van cognities zijn tevens items van de Respiratory Illness Opinion Survey (RIOS; Staudenmayer et al., 1978).

De ervaring binnen de klinische praktijk leert dat bovenstaande en andere disfunctionele cognities over het algemeen niet het directe gevolg zijn van het leven met de aandoening maar juist verband houden met premorbide ervaringen en persoonlijkheidseigenschappen. Zo blijkt een persoonlijkheid met ontwijkende trekken over het algemeen te beschikken over andere basisassumpties en daaruit voortkomende cognities, dan een persoonlijkheid met afhankelijke trekken of een persoonlijkheid met narcistische trekken. Gezien het bovenstaande dient de klinisch psycholoog in een astmacentrum te beschikken over goede diagnostische en therapeutische vaardigheden.

Samenvattend kan worden gesteld dat longrevalidatie een multidisciplinaire behandelvorm is Verschiliende disciplines werken in nauw onderling overleg aan de gestelde revalidatiedoelen. De actieve inbreng van de patiënt is daarbij van wezenlijk belang. Het veelvoud van behandelonderdelen en de variatie die daarbij in de literatur wordt aangetroffen geven aan dat de term longrevalidatie een 'containerbegrip' is. 


\subsection{Effectonderzoek naar longrevalidatie}

In deze paragraaf worden enkele onderzoek naar effecten van longrevalidatie samengevat. Het literatuurbestand waarop deze studie is gebaseerd, is samengesteld op grond van raadpleging van de Medline CD-Rom vanaf 1966. Er werd gezocht aan de hand van de trefwoorden 'lung disease, obstructive', en 'rehabilitation'. De hieruit verkregen selectie van literatuur werd aangevuld met enkele titels verkregen uit de referentielijsten van de op bovenstaande wijze verkregen artikelen. In totaal worden 24 studies samengevat, waarvan zeven werden verricht in Nederland. Het meerendeel betreft Amerikaans onderzoek.

In de hiemavolgende alinea worden enkele methodologische tekortkomingen van effectonderzoek naar longrevalidatie opgesomd. In de eerste plaats ontbreekt in veel studies een controlegroep. Wanneer een controlegroep wordt gebruikt blijkt dat deze in de meeste gevallen niet gematched is. Belangrijk is te matchen op diagnose (astma dan wel COPD), op ernst van de aandoening en variabelen als geslacht en leeftijd. In de verschillende studies blijkt onduidelijkheid over de diagnoses astma en COPD te bestaan. In veel studies wordt geen onderscheid aangegeven tussen astma en COPD, of er wordt niet aangegeven volgens welke criteria tot de beide diagnoses werd besloten. In een aantal onderzoeken wordt gebruik gemaakt van de term COPD waaronder in sommige gevallen ook astma moet worden begrepen. Vervolgens blijkt de aard van de afhankelijke variabelen verschillend te zijn. Hieruit vloeit voort dat ook het meetinstrumentarium dat wordt gebruikt ter bepaling van de pre- en postmeting eveneens per onderzoek verschilt. Dit bemoeilijkt eveneens de onderlinge vergelijkbaarheid van de studies. Overigens is de moeilijke vergelijkbaarheid ook het gevolg van dat wat geëvalueerd wordt, het longrevalidatieprogramma zelf. In de meeste studies wordt een andere samenstelling van interventies gehanteerd. Er blijkt sprake van een cocktailbenadering (met meerdere interventies tegelijk werken aan de doelstelling) waacdonr het niet mygeljik is aan te geven welk onderdeel van het longrevalidatieprogramma het meest heeft bijgedragen aan het bereikte effect. Toch wordt het effect veelal toegeschreven aan een deelinterventie, meestal de inspanningstraining.

In tabel 2.2. staan de onderzoeken samengevat. De tabel is samengesteld volgens de volgende indeling: de eerste auteur, het publicatiejaar, de omvang van de groep patiënten, de gemiddelde leeftijd en de diagnose van de onderzoekspopulatie, de aard van de setting waarbinnen de longrevalidatie piaatsvond (intramuraal of extramuraal), het accent binnen het longrevalidatieprogramma waarover evaluatie plaatsvond ', de follow-up periode, of er gebruik werd gemaakt van een controlegroep, de aard van de afhankelijke variabelen ${ }^{2}$ en ten slotte een samenvatting van de belangrijkste resultaten van het betreffende onderzoek.

\footnotetext{
' Er werd een onderscheid aangebracht tussen technische en psychologische interventies. Onder eerstgenoemde ressorteren inspanningstraining, medicamenteuze therapie en fysiotherapie, waaronder ademhalingsoefeningen. Onder psychologische interventies moeten in deze tabel alle interventies worden begrepen die niet onder de technische vallen, dat wil zeggen psychologische behandelingen, psychosociale ondersteuning. maar ook GVO of wat veelal met 'patient education' wordt aangeduid.

${ }^{2}$ Hierbij werd onderscheid gemaakt tussen technische variabelen waaronder fysiologische parameters, longfunctiematen! en bloedgaswaarden, en psychologische variabelen, waaronder de kwaliteit van leven, het welbevinden, etc.
} 
Tabel 2.2. Effectonderzoek longrevalidatie

\begin{tabular}{|c|c|c|c|c|c|c|c|c|c|}
\hline \multirow{2}{*}{$\begin{array}{l}\text { Eerste } \\
\text { auteut } \\
\text { (jaar) }\end{array}$} & \multicolumn{3}{|c|}{ Populatie } & \multirow[t]{2}{*}{ Setting } & \multirow[t]{2}{*}{ Interventies } & \multirow{2}{*}{$\begin{array}{l}\text { Follow- } \\
\text { up }\end{array}$} & \multirow{2}{*}{$\begin{array}{l}\text { Controle- } \\
\text { groep }\end{array}$} & \multirow{2}{*}{$\begin{array}{l}\text { Afhankelijke } \\
\text { variabelen }\end{array}$} & \multirow[t]{2}{*}{ Resultaat } \\
\hline & $N$ & Leeftijd & Diagnose & & & & & & \\
\hline $\begin{array}{l}\text { Nicholas } \\
(1970)\end{array}$ & 8 & 60 jaar & COPD & $\begin{array}{l}\text { extra- } \\
\text { muraal }\end{array}$ & $\begin{array}{l}\text { technisch (inspan- } \\
\text { ningstraining) }\end{array}$ & gecn & nee & $\begin{array}{l}\text { technisch en } \\
\text { prychologisch }\end{array}$ & $\begin{array}{l}\text { Geen verbetering van de longfunctie, wel } \\
\text { toename van de inspanningstolerantie; oen } \\
\text { toegenomen welbevinden en zelfvertrouwen }\end{array}$ \\
\hline $\begin{array}{l}\text { Fishman } \\
\text { (1971) }\end{array}$ & 30 & $\begin{array}{l}\text { volwas- } \\
\text { senen }\end{array}$ & COPD & $\begin{array}{l}\text { extra- } \\
\text { muraal }\end{array}$ & $\begin{array}{l}\text { technisch en } \\
\text { psychologisch }\end{array}$ & I jaar & nee & $\begin{array}{l}\text { technisch en } \\
\text { pyychologisch }\end{array}$ & $\begin{array}{l}\text { Verbetering in ventilatie, verbetering stem- } \\
\text { ming. geen veranderingen met betrekking } \\
\text { tot afhankelijkcid en psychoputhologie }\end{array}$ \\
\hline $\begin{array}{l}\text { McGavin } \\
(1977)\end{array}$ & 24 & 61 jaar & Cara & $\begin{array}{l}\text { extra- } \\
\text { muraal }\end{array}$ & $\begin{array}{l}\text { technisch (inspan- } \\
\text { ningstraining) }\end{array}$ & geen & ja & $\begin{array}{l}\text { technisch en } \\
\text { prychologiach }\end{array}$ & $\begin{array}{l}\text { Geen verandering van het lichaamsewicht, } \\
\text { de longfunctie en de hartilag, wel van psy- } \\
\text { chologische kenmerken. Paticnten in de } \\
\text { ccantrolegroep rapporteerden deze veran- } \\
\text { deringen niet. }\end{array}$ \\
\hline $\begin{array}{l}\text { Shapiro } \\
\text { (1977) }\end{array}$ & 118 & 63 jaar & COPD & $\begin{array}{l}\text { intramu- } \\
\text { ral }\end{array}$ & $\begin{array}{l}\text { technisch en psy- } \\
\text { chologisch }\end{array}$ & $\begin{array}{l}1 \mathrm{en} 6 \\
\text { mnd en } 1 \\
\text { en } 2 \text { jar }\end{array}$ & nee & $\begin{array}{l}\text { tectunisch en } \\
\text { prychologisch }\end{array}$ & $\begin{array}{l}\text { Er werden verbeteringen geconstateend op } \\
\text { de emotionele en de psychologuiche ken: } \\
\text { merken. de inspanningrapaciteit en de } \\
\text { longfunctie. }\end{array}$ \\
\hline
\end{tabular}




\begin{tabular}{|c|c|c|c|c|c|c|c|c|c|}
\hline $\begin{array}{l}\text { Eerste } \\
\text { auteur } \\
\text { (jaar) }\end{array}$ & $N$ & Leeftijd & Diagnose & Setting & Interventies & $\begin{array}{l}\text { Follow- } \\
\text { up }\end{array}$ & $\begin{array}{l}\text { Controle- } \\
\text { groep }\end{array}$ & $\begin{array}{l}\text { Afhankelijke } \\
\text { variabelen }\end{array}$ & Resultaat \\
\hline $\begin{array}{l}\text { Gimeno } \\
\text { (1979; } \\
1986)\end{array}$ & 85 mannen & 59 jaar & Cara & $\begin{array}{l}\text { intramu- } \\
\text { raal }\end{array}$ & $\begin{array}{l}\text { technisch (inspan- } \\
\text { ningstraining) }\end{array}$ & 6 jaar & nee & technisch & $\begin{array}{l}\text { Op de korte termijn werden verbeteringen } \\
\text { vastgesteld qua inspanningscapaciteit en } \\
\text { longfunctie (1979). Op de lange termijn } \\
\text { werd een verbetering geconstateerd op het } \\
\text { vlak van de medische consumptie (heropna- } \\
\text { men, poliklinische contacten, antibiotica- } \\
\text { gebruik) en het verloop van de longfunctic. } \\
\text { De inspanningscapaciteit van de revalidatie- } \\
\text { groep bleek bij follow-up niet beter dan die } \\
\text { van de controlegroep. }\end{array}$ \\
\hline $\begin{array}{l}\text { Moser } \\
(1980)\end{array}$ & 42 & 67 jaar & COPD & $\begin{array}{l}\text { intramu- } \\
\text { raal }\end{array}$ & $\begin{array}{l}\text { technisch (inspan- } \\
\text { ningstraining) }\end{array}$ & geen & nee & technisch & $\begin{array}{l}\text { Zuurstof, hartslag-en ademhalingsfrequen- } \\
\text { tie blijken toegenomen. Bij } 16 \text { van de } 29 \\
\text { patiènten verbeterde de ervaring van kort- } \\
\text { ademigheid, bij } 11 \text { van de } 29 \text { de ervaren } \\
\text { beperkingen in dagelijkse activiteiten. }\end{array}$ \\
\hline $\begin{array}{l}\text { Sahn } \\
\text { (1980) }\end{array}$ & 182 & 61 jaar & COPD & $\begin{array}{l}\text { extra- } \\
\text { muraal }\end{array}$ & $\begin{array}{l}\text { technisch en psy- } \\
\text { chologisch }\end{array}$ & $\begin{array}{l}\text { tot } 10 \\
\text { jaar }\end{array}$ & nee & technisch & $\begin{array}{l}\text { Na } 3 \text { jaar leefde nog } 64 \% \text {, na } 5 \text { jaar nog } \\
41 \text { \% en na } 10 \text { jaar nog } 17 \% \text { van de on- } \\
\text { derzoeksgroep. Er bleck een afname van } \\
\text { het aantal ziekenhuisdagen in verband met } \\
\text { de Cara-klachten, een verbetering van de } \\
\text { Cara-symptomen en een verbeterde levens- } \\
\text { stijl. De mate van succes van het program- } \\
\text { ma bleek afhankelijk van het moment waar } \\
\text { op het programma startte binnen het sta- } \\
\text { dium van de aandoening: hoe eerder, hoe } \\
\text { beter. }\end{array}$ \\
\hline
\end{tabular}




\begin{tabular}{|c|c|c|c|c|c|c|c|c|c|}
\hline $\begin{array}{l}\text { Eerste } \\
\text { auteur } \\
\text { (jaar) }\end{array}$ & $N$ & Leeftijd & Diagnose & Setting & Interventies & $\begin{array}{l}\text { Follow. } \\
\text { up }\end{array}$ & $\begin{array}{l}\text { Controle- } \\
\text { groep }\end{array}$ & $\begin{array}{l}\text { Afhankelijke } \\
\text { variabelen }\end{array}$ & Resultaat \\
\hline $\begin{array}{l}\text { Sinclair } \\
\text { (1980) }\end{array}$ & 15 & 66 jaar & Cara & $\begin{array}{l}\text { extra- } \\
\text { muraal }\end{array}$ & $\begin{array}{l}\text { technisch (inspan- } \\
\text { ningstraining) }\end{array}$ & geen & ja & $\begin{array}{l}\text { Iechnisch en } \\
\text { psychologisch }\end{array}$ & $\begin{array}{l}\text { Er bleek na } 8 \text { tot } 12 \text { maanden bij alle is } \\
\text { patienten een toename te hebben plaatsge- } \\
\text { vonden van de } 12 \text {-minuten loopafistand. } \\
\text { Tevens bleek bij alle patiënten een afname } \\
\text { van kortademigheidsklachten. Bij } 12 \text { pati- } \\
\text { enten werd een verbetering van het gevoel } \\
\text { van welbevinden geconstateerd en bij } 10 \\
\text { een toenarne in mogelijkhoden tot het uit- } \\
\text { voeren van dagelijkse activiteiten. }\end{array}$ \\
\hline $\begin{array}{l}\text { Cockcroft } \\
\text { (1981) }\end{array}$ & 34 & 61 jaar & Cara & $\begin{array}{l}\text { intra- } \\
\text { muraal }\end{array}$ & $\begin{array}{l}\text { technisch (inspan- } \\
\text { ningstraining) }\end{array}$ & geen & ja & $\begin{array}{l}\text { technisch en } \\
\text { psychologisch }\end{array}$ & $\begin{array}{l}\text { De insparningstolerantie en het algeheel } \\
\text { welbevinden verbeterde wel in de inspan. } \\
\text { ningstrainingsyoep, niet in de controle- } \\
\text { grocp. Er vond geen verbetering plaats van } \\
\text { de longfunctie. }\end{array}$ \\
\hline $\begin{array}{l}\text { Atkins } \\
\text { (1984) }\end{array}$ & 76 & 65 jaar & Cara & $\begin{array}{l}\text { extra- } \\
\text { muraal }\end{array}$ & psychologisch & $\begin{array}{l}3 \text { en } 6 \\
\text { maanden }\end{array}$ & ja & $\begin{array}{l}\text { techinisch en } \\
\text { psychologisch }\end{array}$ & $\begin{array}{l}\text { Bij de patienten uit de drie experimentele } \\
\text { groepen (gedrapumodificatie, cognitieve } \\
\text { modificatie en cognitieve-gedraysmodifica- } \\
\text { tie) verbeterde de loopafstand, bij die uit de } \\
\text { controlegroepen niet. Gedurende de cerste } \\
\text { drie maanden na behandeling bieek de } \\
\text { inspanningstolerantie in de experimentele } \\
\text { goepen verbetend, in de controlegroepen } \\
\text { was deze verslechaterd. Het algemeen wel- } \\
\text { bevinden steeg in de experimentele groe- } \\
\text { pen, niet in de controleproepen. }\end{array}$ \\
\hline
\end{tabular}




\begin{tabular}{|c|c|c|c|c|c|c|c|c|c|}
\hline $\begin{array}{l}\text { Eerste } \\
\text { auteur } \\
\text { (jaar) }\end{array}$ & $\boldsymbol{N}$ & Leeftijd & Diagnose & Setting & Interventies & $\begin{array}{l}\text { Follow- } \\
\text { up }\end{array}$ & $\begin{array}{l}\text { Controle- } \\
\text { groep }\end{array}$ & $\begin{array}{l}\text { Afhankelijke } \\
\text { variabelen }\end{array}$ & Resultaat \\
\hline $\begin{array}{l}\text { Guyatt } \\
\text { (1987) }\end{array}$ & 31 & 65 jaar & Cara & $\begin{array}{l}\text { extra- } \\
\text { muraal }\end{array}$ & $\begin{array}{l}\text { technisch en psy- } \\
\text { chologisch }\end{array}$ & $\begin{array}{l}6 \text { maan- } \\
\text { den }\end{array}$ & nee & $\begin{array}{l}\text { pechnisch en } \\
\text { psychologisch }\end{array}$ & $\begin{array}{l}\text { De kwaliteit van leven en de inspanningsca- } \\
\text { paciteit bleken na } 2 \text { weken bij } 24 \text { van de } 31 \\
\text { patiênten verbeterd. Na } 6 \text { maanden was dit } \\
\text { nog bij } 11 \text { van de } 31 \text { patiēnten het geval. } \\
\text { De eerste } 6 \text { maanden na revalidatie bleek } \\
\text { een grote teruggang van het resultaat. }\end{array}$ \\
\hline $\begin{array}{l}\text { Carter } \\
\text { (1988) }\end{array}$ & 59 & 62 jasr & COPD & $\begin{array}{l}\text { intra- } \\
\text { muraal }\end{array}$ & $\begin{array}{l}\text { technisch (inspan- } \\
\text { ningstraining) }\end{array}$ & $\begin{array}{l}3 \text { man: } \\
\text { den }\end{array}$ & nee & $\begin{array}{l}\text { technisch en } \\
\text { psychologisch }\end{array}$ & $\begin{array}{l}\mathrm{Na} 12 \text { dagen training blijkt geen verbete- } \\
\text { ring in de longfunctie te zijn opgetreden, } \\
\text { wel in inspannings- en ademhalingsfysi- } \\
\text { ologische maten. Deze resultaten blijken na } \\
3 \text { maanden nog steeds te bestaan. }\end{array}$ \\
\hline $\begin{array}{l}\text { Mall } \\
\text { (1988) }\end{array}$ & 236 & 60 jaar & Cara & $\begin{array}{l}\text { intamu- } \\
\text { raal }\end{array}$ & $\begin{array}{l}\text { lechnisch (inspan- } \\
\text { ningstraining) }\end{array}$ & $\begin{array}{l}1 \text { en } 5 \\
\text { jaar }\end{array}$ & nee & $\begin{array}{l}\text { technisch en } \\
\text { psychologisch }\end{array}$ & $\begin{array}{l}\text { Bij } 86 \% \text { werd een verbetering aangetroffen } \\
\text { in de functionele capaciteit, de kennis on- } \\
\text { trent de aandoening en de kwaliteit van } \\
\text { leven. Tijdens de follow-up van } 5 \text { jaar } \\
\text { blijkt } 32 \% \text { nog steeds verbeterd, } 36 \% \\
\text { verslechterd en } 32 \% \text { bleek te zijn overle- } \\
\text { den. }\end{array}$ \\
\hline $\begin{array}{l}\text { Van der } \\
\text { Schoot } \\
(1988)\end{array}$ & 88 & 53 jaar & Cara & $\begin{array}{l}\text { intra- } \\
\text { muraal }\end{array}$ & $\begin{array}{l}\text { technisch en psy- } \\
\text { chologisch }\end{array}$ & $\begin{array}{l}6 \text { maan- } \\
\text { den }\end{array}$ & nee & $\begin{array}{l}\text { technisch en } \\
\text { psychologisch }\end{array}$ & $\begin{array}{l}\text { Geen verbeteringen op het vlak van de } \\
\text { longfunctic, wel op medische consumptie, } \\
\text { psychologische variabelen en ervaren be- } \\
\text { perkingen in dagelijkse activiteiten. }\end{array}$ \\
\hline
\end{tabular}




\begin{tabular}{|c|c|c|c|c|c|c|c|c|c|}
\hline $\begin{array}{l}\text { Eerste } \\
\text { auteur } \\
\text { (jaar) }\end{array}$ & N & Leeftijd & Diagnose & Setting & Interventies & $\begin{array}{l}\text { Follow- } \\
\text { up }\end{array}$ & $\begin{array}{l}\text { Controle- } \\
\text { groep }\end{array}$ & $\begin{array}{l}\text { Afhankelijke } \\
\text { variabelen }\end{array}$ & Resultaat \\
\hline $\begin{array}{l}\text { Dek- } \\
\text { huijzen } \\
(1990)\end{array}$ & 60 & 59 jaar & COPD & $\begin{array}{l}\text { intra- } \\
\text { muraal }\end{array}$ & $\begin{array}{l}\text { technisch en psy- } \\
\text { chologisch }\end{array}$ & 1 jaar & ja & $\begin{array}{l}\text { technisch en } \\
\text { psychologisch }\end{array}$ & $\begin{array}{l}\text { Patiènten bleken na het programma gunsti- } \\
\text { ger te scoren op angst, depressie en alge- } \\
\text { mene dagelijke levensverrichtingen (adl). } \\
\text { Na een jaar bleck de angst en depressie nog } \\
\text { steeds gunstiger dan voor het programma, } \\
\text { de adl echter niet meer. De } 12 \text { minuten } \\
\text { looptest bleek te zijn verbeterd, zowel vlak } \\
\text { na het programma als gedurende de follow. } \\
\text { up van een jar. }\end{array}$ \\
\hline $\begin{array}{l}\text { Kersten } \\
\text { (1990) }\end{array}$ & 37 & 55 jaar & COPD & $\begin{array}{l}\text { intra- } \\
\text { muraal }\end{array}$ & $\begin{array}{l}\text { technisch en psy- } \\
\text { chologisch }\end{array}$ & $\begin{array}{l}2 \text { en } 6 \\
\text { maanden }\end{array}$ & nee & prychologisch & $\begin{array}{l}\text { Er traden qua zelf-concept gunstige veran- } \\
\text { deringen op tijdens de verschillende stadia } \\
\text { van het longrevalidatieproces, niet meer } \\
\text { tijdens de follow-up. Mannen ventoonden in } \\
\text { dit opzicht meer verbetering dan vrouwen, } \\
\text { maar tevens een grotere teruatang tijdens } \\
\text { de follow-up. }\end{array}$ \\
\hline $\begin{array}{l}\text { Toshima, } \\
\text { (1990) }\end{array}$ & 119 & 63 jaar & Cara & $\begin{array}{l}\text { extra- } \\
\text { muraal }\end{array}$ & $\begin{array}{l}\text { technisch en psy- } \\
\text { chologisch }\end{array}$ & $\begin{array}{l}6 \text { maan: } \\
\text { den }\end{array}$ & ja & $\begin{array}{l}\text { technisch en } \\
\text { psychotogisch }\end{array}$ & $\begin{array}{l}\text { De groep die een inspanningstraining on- } \\
\text { derging verbeterde meer qua insparnings- } \\
\text { capuciteit en prychologische kenmerken dan } \\
\text { de controlegroep, die gees inspan- } \\
\text { ningstraining maur wel andere interventies } \\
\text { kreeg. }\end{array}$ \\
\hline
\end{tabular}




\begin{tabular}{|c|c|c|c|c|c|c|c|c|c|}
\hline $\begin{array}{l}\text { Eerste } \\
\text { auteur } \\
\text { (jaar) }\end{array}$ & $N$ & Leeftijd & Diagnose & Setting & Interventies & $\begin{array}{l}\text { Follow- } \\
\text { up }\end{array}$ & $\begin{array}{l}\text { Controle- } \\
\text { groep }\end{array}$ & $\begin{array}{l}\text { Afhankelijke } \\
\text { variabelen }\end{array}$ & Resultaat \\
\hline $\begin{array}{l}\text { Swerts } \\
\text { (1990) }\end{array}$ & 24 & 61 jaar & COPD & $\begin{array}{l}\text { extra- } \\
\text { muraal }\end{array}$ & technisch & $\begin{array}{l}6 \text { en } 12 \\
\text { maanden }\end{array}$ & ja & technisch & $\begin{array}{l}\text { De inspanningstolerantie van alle patiënten } \\
\text { bleek na het programma van } 12 \text { weken } \\
\text { verbeterd. De kortademigheid en de long- } \\
\text { functie niet. Bij de putiënten die bovenop } \\
\text { de } 8 \text { weken, } 12 \text { weken extra training kre- } \\
\text { gen, bleek de verbetering van de inspan- } \\
\text { ningstolerantie } 12 \text { maanden na het afronden } \\
\text { van het programma nog steeds te bestaan, } \\
\text { terwijl in die } 12 \text { maanden een afname hier- } \\
\text { van bij de patiénten uit de groep die alleen } \\
8 \text { weken training hadden gehad werd waar- } \\
\text { genomen. }\end{array}$ \\
\hline $\begin{array}{l}\text { Emery } \\
\text { (I991) }\end{array}$ & 64 & $\begin{array}{l}53-82 \\
\text { jaar }\end{array}$ & COPD & $\begin{array}{l}\text { extra- } \\
\text { muraal }\end{array}$ & $\begin{array}{l}\text { technish (inspan- } \\
\text { ningstraining) }\end{array}$ & geen & nee & $\begin{array}{l}\text { technisch en } \\
\text { psychologisch }\end{array}$ & $\begin{array}{l}\text { Er werden verbeteringen in fysieke moge- } \\
\text { lijkheden geconstateerd. Verder bleek er } \\
\text { een afname van depressie en angst, een } \\
\text { verbetering van het aigemeen welbevinden } \\
\text { en van het neuropsychologisch functione- } \\
\text { ren. }\end{array}$ \\
\hline $\begin{array}{l}\text { Cox } \\
\text { (1991) }\end{array}$ & 87 & 43 jaar & Cara & $\begin{array}{l}\text { intra- } \\
\text { muraal }\end{array}$ & $\begin{array}{l}\text { technisch en psy- } \\
\text { chologisch }\end{array}$ & 1 jaar & ja & $\begin{array}{l}\text { technisch en } \\
\text { psychologisch }\end{array}$ & $\begin{array}{l}\text { Op alle meetmomenten bleck er een verbe- } \\
\text { tering in inspanningstolerantie, psychologi- } \\
\text { sche kenmerken, medische consumptic, } \\
\text { levensstijl en rookgedrag. De luchtwegob- } \\
\text { structie, dyspnoe en allergie vertoonden } \\
\text { alleen verbetering op korte termijn. De } \\
\text { bronchiale hyperreactiviteit, het medicatie- } \\
\text { gebruik, de hoest- en sputumklachten lieten } \\
\text { geen verbetering zien. }\end{array}$ \\
\hline
\end{tabular}




\begin{tabular}{|c|c|c|c|c|c|c|c|c|c|}
\hline $\begin{array}{l}\text { Eerste } \\
\text { auteur } \\
\text { (jaar) }\end{array}$ & $N$ & Leeftijd & Diagnose & Setting & Interventies & $\begin{array}{l}\text { Follow. } \\
\text { up }\end{array}$ & $\begin{array}{l}\text { Controle- } \\
\text { groep }\end{array}$ & $\begin{array}{l}\text { Afhankelijke } \\
\text { variabelen }\end{array}$ & Resultaat \\
\hline $\begin{array}{l}\text { Nieder- } \\
\text { man } \\
\text { (1991) }\end{array}$ & 33 & 66 jaar & Cara & $\begin{array}{l}\text { extra- } \\
\text { muraal }\end{array}$ & technisch & geen & nee & $\begin{array}{l}\text { technisch en } \\
\text { prychologisch }\end{array}$ & $\begin{array}{l}\text { Het uithoudingsvermogen ( } 12 \text { minuten } \\
\text { looptest) en het welbevinden verbeterden } \\
\text { significant. De maximale inspanningsmoge- } \\
\text { lijkhheid verbeterde weinig. Er bleek afna- } \\
\text { me van zuurstofconsumptie. De verbeterin- } \\
\text { gen waren niet afhankelijk van de emst van } \\
\text { de aandoening en de longfunctie. }\end{array}$ \\
\hline $\begin{array}{l}\text { Ojanen } \\
\text { (1993) }\end{array}$ & 40 & 63 jaar & COPD & $\begin{array}{l}\text { intra- } \\
\text { muraal }\end{array}$ & technisch & $\begin{array}{l}6 \text { maan- } \\
\text { den }\end{array}$ & nee & $\begin{array}{l}\text { techinische en } \\
\text { paychologisch }\end{array}$ & $\begin{array}{l}\text { De onmiddellijke effecten op variabelen die } \\
\text { subjectieve ervaring meten waren positief: } \\
\text { welbevinden, emotionele toestand en respi- } \\
\text { ratoire symptomen verbeterden significant. } \\
\text { Echter, aln het einde van de follow-up } \\
\text { periode waren de behandeleffecten verdwe- } \\
\text { nen. }\end{array}$ \\
\hline $\begin{array}{l}\text { Wijkstra } \\
\text { (1994) }\end{array}$ & 45 & 63 jaar & COPD & $\begin{array}{l}\text { extray } \\
\text { muraal } \\
\text { (thuis) }\end{array}$ & technisch & geen & ja & $\begin{array}{l}\text { technisch en } \\
\text { prychologisch }\end{array}$ & 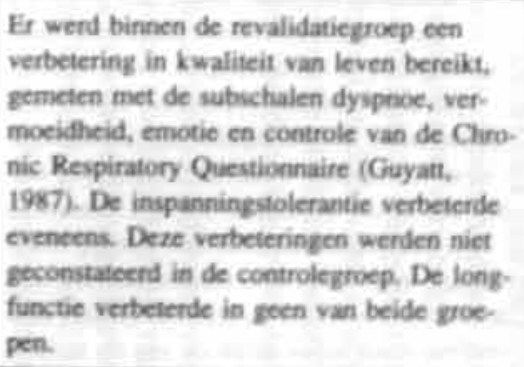 \\
\hline
\end{tabular}




\begin{tabular}{|l|l|l|l|l|l|l|l|l|l|}
\hline $\begin{array}{l}\text { Eerste } \\
\text { auteur } \\
\text { (jaar) }\end{array}$ & N & Leeftijd & Diagnose & Setting & Interventies & Follo-up & $\begin{array}{l}\text { Controle- } \\
\text { groep }\end{array}$ & $\begin{array}{l}\text { Afhankelijke } \\
\text { variabelen }\end{array}$ & Resultaat \\
\hline $\begin{array}{l}\text { Sassi- } \\
\text { Dambron } \\
\text { (1995) }\end{array}$ & 89 & 67 jaar & COPD & $\begin{array}{l}\text { extra- } \\
\text { mural }\end{array}$ & $\begin{array}{l}\text { psychologisch } \\
\text { (coping kortade- } \\
\text { migheid) }\end{array}$ & $\begin{array}{l}6 \text { maan- } \\
\text { den }\end{array}$ & ja & $\begin{array}{l}\text { technisch en } \\
\text { psychologisch }\end{array}$ & $\begin{array}{l}\text { Het betreft een gerandomiseerd onderzoek } \\
\text { om een beknopt longrevalidatoeprogramma. } \\
\text { gericht op het op juiste wijze leren omgain } \\
\text { met kortademigheid te evalueren. Kenmerk } \\
\text { van het programma was verder het achter- } \\
\text { wege blijven van inspanningstraining. De } \\
\text { resultaten van het onderzoek geven aan dat } \\
\text { een behandelprogramma, gericht op co- } \\
\text { pingstrategieên, zonder andere interventies, } \\
\text { waaronder inspanningstraining, niet vol- } \\
\text { doende is om verbeteringen te bereiken in } \\
\text { kortademigheid, inspanningstolerantie. } \\
\text { kwaliteit van leven, angst en depressic. }\end{array}$ \\
\hline
\end{tabular}


Tabel 2.2. geeft een overzicht van literatuur over effectonderzoek naar longrevalidatie. Hieruit blijkt in grote lijnen dat bij dergelijk onderzoek een verscheidenheid aan interventies wordt geëvalueerd aan de hand van een verscheidenheid aan uitkomstvariabelen. Van de 24 studies die werden bekeken, hadden er 10 betrekking op zowel technische (meestal inspanningstraining) als psychologische en/of sociale interventies. Van deze 10 studies waren er negen die eveneens afhankelijke variabelen hadden gekozen van zowel technische (wederom meestal inspanningstolerantie), als van psychologische en sociale aard. Eén van deze studies onderzocht alleen het effect op psychologisch vlak.

Van de 25 studies kozen er 14 alleen de technische interventies tot onderwerp van evaluatiestudie. Van deze 14 studies waren er negen die de effecten zowel in termen van technische als psychologische kenmerken beschreven. De overige vier onderzoeken beschreven de effectiviteit van de revalidatie alleen met behulp van technische kenmerken.

Slechts twee onderzoeken hadden betrekking op psychologisch of gedragsinterventies, waarbij de uitkomsten werden bekeken op zowel technische als psychologische kenmerken.

Met betrekking tot de gebruikte methode van onderzoek blijkt $50 \%$ van de studies gebruik te hebben gemaakt van een follow-upperiode. In veel onderzoeken lijkt de randomisering van deze controlegroepen echter te wensen over te laten. Een derde van de onderzoeken maakte geen gebruik van een controlegroep. In de overige studies blijkt de periode waarover de resultaten worden bekeken te variëren tussen 3 maanden en 10 jaar.

Hoewel tegen de achtergrond van de genoemde methodologische tekorten voorzichtigheid is geboden, kan in grote lijnen uit de samengevatte studies geconcludeend worden, dat longrevalidatic (of een deelinterventie daaruit) gezondheidswinst oplevert, hetgeen tot uitdrukking kan komen in zowel de inspanningsmogelijkheden, de medische consumptie, alsook in psychologische kenmerken.

In het hiema volgende hoofdstuk wordt de opzet van het evaluatieonderzoek omtrent het longrevalidatieprogramma van het NAD uiteengezet. 


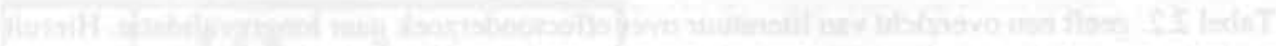

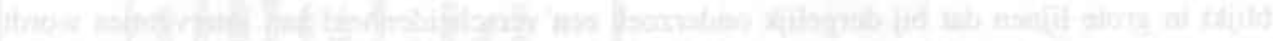

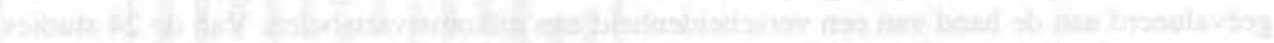

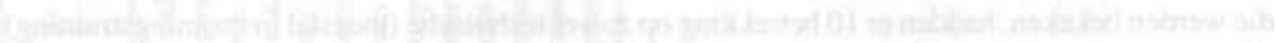

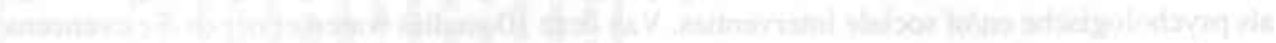

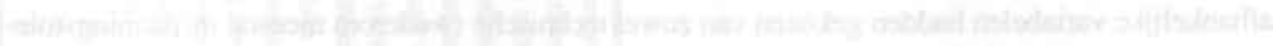

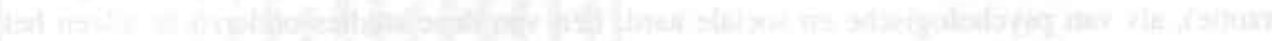

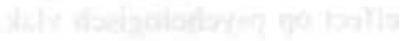
-

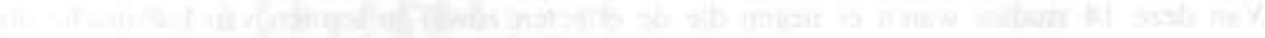

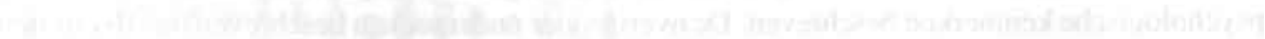

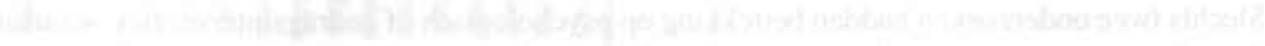

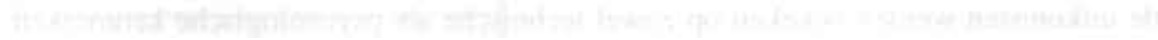




\subsection{Inleiding}

In dit hoofdstuk worden allereerst de vragen die aan dit onderzoek ten grondslag liggen geformuleerd. Vervolgens wordt de methode die werd gehanteend ter beantwoording van deze vragen besproken. Daartoe wordt om te beginnen de samenstelling van de onderzoeksgroep beschreven en een omschrijving van de gebruikte variabelen en meetinstrumenten gegeven. Dan worden per vraagstelling de variabelen en wanneer dat voor de vraagstelling relevant is, de onderverdeling in afhankelijke en onafhankelijke variabelen beschreven, gevolgd door een beschrijving van de gehanteerde statistische procedure. Ten slotte volgt de onderzoeksprocedure.

\subsection{Vraagstellingen}

De volgende vragen bepalen de gang van het onderzoek:

1. Wat zijn kenmerken van patiënten die worden opgenomen in het Nederlands Astmacentrum Davos, beschreven in termen van longfunctie, rookgedrag, aspecten van medische consumptie (aantallen huisarts- en specialistbezoeken, ziekenhuisopnamen, ziekenhuisdagen en hoeveelheid voorgeschreven medicatie) en in termen van aspecten van kwaliteit van leven (functionele, psychologische en sociale aspecten)?

2. Wat is het beloop van scores op de kenmerken die aspecten van kwaliteit van leven en medische consumptie uitdrukken gemeten over de meetmomenten opname, ontslag, 6 maanden na ontslag en 12 maanden na ontslag?

3. Hoeveel patiènten zijn, gemeten 12 maanden na ontslag, in vergelijking met het moment van opname verbeterd, verslechterd of onveranderd met betrekking tot de in de tweede vraagstelling genoemde aspecten van kwaliteit van leven en van medische consumptie?

4. Wat zijn determinanten van verbetering en van verslechtering op aspecten van medische consumptie en op de ervaren beperkingen in dagelijkse activiteiten?

5. In hoeverre hangt het veranderd zijn (in gunstige zin) op enkele psychologische en longfunctiekenmerken samen met de verbeteringen op de ervaren beperkingen in dagelijkse. activiteiten en op enkele aspecten van medische consumptie, te weten de frequentie en de duur van ziekenhuisopnamen vanwege Cara en het oraal corticosteroïdgebruik?

\subsection{Methode}

\subsubsection{Samenstelling van de onderzoeksgroep.}

De onderzoeksgroep bestaat uit alle patiènten die in de periode januari 1989 tot januari 1990 werden opgenomen op de Volwassenenafdeling van het NAD. Het betrof in totaal 162 patiěnten. Er werd gekozen voor deze periode van één jaar, omdat daarmee een populatie in kaart wordt gebracht die de kenmerken of de gevolgen van alle seizoensinvloeden in zich draagt. De gemiddelde opnameduur van de onderzoeksgroep bedroeg $96 \pm 27$ dagen (min. 42 dagen; max. 183 dagen).

Patiënten die korter dan 6 weken in het NAD verbleven $(N=4)$ of patiènten die korter dan één jaar na ontslag werden heropgenomen in het NAD $(N=10)$ werden niet in de onderzoeksgroep opgenomen. De laatstgenoemde groep van patiënten werd van onderzoek uitgesloten aangezien 
bij hen van tevoren min of meer vaststond dat ze ieder jaar gedurende een aantal weken in het NAD zouden verblijven. De eerstgenoemde groep werd beschouwd als drop-out. Redenen van drop-out waren heimwee of een bij opneming gebleken te slechte lichamelijke conditie voor een verblijf in het hooggebergte.

Uiteindelijk maakten 148 patiënten deel uit van de onderzoeksgroep. Een beschrijving van demografische en andere achtergrondgegevens van deze groep van patiënten wordt gepresenteerd in tabel 3.1 .

Tabel 3.1. Achtergrondkenmerken van de onderzoeksgroep $(N=148)$

\begin{tabular}{|c|c|c|c|}
\hline & $N$ & & $\%$ \\
\hline \multicolumn{4}{|l|}{ geslacht $(N=148)$} \\
\hline $\operatorname{man}$ & 67 & & 45 \\
\hline vrouw & 81 & & 55 \\
\hline \multicolumn{4}{|l|}{ burgerlijke staat $(N=145)$} \\
\hline gehuwd/samenlevend & 95 & & 66 \\
\hline ongehuwd/alleenwonend & 50 & & 35 \\
\hline \multicolumn{4}{|l|}{ opleidingsniveau $(\mathrm{N}=118)$} \\
\hline laag (minder dan middelbaar) & 73 & & 62 \\
\hline hoog (middelbaar of meer) & 45 & & 38 \\
\hline \multicolumn{4}{|l|}{ diagnose* $(N=148)$} \\
\hline astma & 35 & & 24 \\
\hline \multirow[t]{2}{*}{ COPD } & 113 & & 76 \\
\hline & $M$ & (SD) & $\min / \max$ \\
\hline leeftijd bij opname $(N=148)$ & 51.7 & $(13,6)$ & $16 / 80$ \\
\hline duur van de aandoening in jaren $(N=122)$ & 21.4 & $(16.8)$ & $0 / 69$ \\
\hline
\end{tabular}

voor de criteria zie paragraaf 3.3 .2 .

Alle patiënten waren tussen de 16 en 80 jaar oud. Hoewel de patiëntenpopulatie van het NAD ook bestaat uit jonge kinderen behoren deze niet tot de onderzoeksgroep aangezien zij een van de volwassenenafdeling afwijkende behandelmethode kregen.

\subsubsection{Variabelen en meetinstrumenten}

Ter beantwoording van de in dit onderzoek gestelde vragen werden verschillende variabelen en meetinstrumenten gebruikt. De volgende variabelen of groepen van variabelen werden gemeten: sociodemografische kenmerken, aandoeningsspecifieke kenmerken, rookgedrag, functionele, psychologische en sociale kenmerken en medische consumptie. Deze worden hiema beschreven. 1. Sociodemografische kenmerken. Leeftijd, geslacht, burgerlijke staat en opleidingsniveau werden verzameld bij opname en verkregen uit de centrale patiëntenregistratie van het NAD.

2. Aandoeningspecifieke kenmerken (longfunctie, diagnose, duur van de aandoening).

Longfunctie. Door middel van longfunctieonderzoek werd de bronchusobstructie geobjectiveerd. Bij herhaalde meting werd inzicht verkregen in de mate van reversibiliteit hiervan. Ten behoeve van het onderzoek vonden longfunctiemetingen plaats door middel van spirometrisch onderzoek. Het percentage van de normwaarde van de FEV, (Forced Expiration Volume in one second) en van de VC (Vitale Capaciteit) werden bepaald. De normwaarden werden ontleend aan standaarden van de European Community for Coal and Steel (ECCS; zie Quanjer, 1983). Deze zijn lengte-. leeftijd- en geslachtsafhankelijk. De longfuncties werden in de eerste week van opname bepaald. 
De FEV is de expiratoire én-seconde waarde, ofwel het luchtvolume dat bij geforceerde maximale expiratie vanuit volledige inspiratie gedurende eén seconde wordt uitgeademd. De VC is het uitgeademd luchtvolume tussen volledige inademing en volledige uitademing (Quanjer, 1983). De waarden van de $\mathrm{FEV}_{1}$ en de VC die in dit onderzoek worden gebruikt zijn percentages van voorspelde waarden (volgens de ECCS-normen) en werden zowel voorafgaand als 20 minuten na inhalatie van $0,4 \mathrm{mg}$ salbutamol (een bronchusverwijder) vastgesteld. De medicatiebeperking voorafgaand aan het meten van de longfunctie was voor alle pariēnten gelijk: het gebruik van inhaleerbare bronchusverwijdende middelen werd 8 uur voor het onderzoek gestaakt en dat van orale $\beta_{2}$-sympaticomimetica, antihistaminica, inhaleerbare cromoglycaten en nedrocromil 48 uur. Het gebruik van theofyllinepreparaten en het oraal en inhalatoir gebruik van corticosteroiden werd vanwege de ernst van de aandoening voortgezet.

Diagnose. Alle patiênten die in het NAD worden opgenomen lijden aan Cara, dat wil zeggen aan astma of COPD (chronische bronchitis en/of longemfyseem), zoals gedefinieerd door de American Thoracic Society (1987). Om te komen tot de diagnose astma diende de FEV, hoger te zijn dan $65 \%$. Bij een afwijkende FEV, diende de reversibiliteit na toediening van $0,4 \mathrm{mg}$ salbutamol meer dan $20 \%$ van de voorspelde waarde te zijn (Quanjer, 1983). Daaraan toegevoegd dienden de patiènten een bronchiale hyperactiviteit te hebben van minimaal $20 \%$, tot uitdrukking komend in een afname van de FEV, na het inhaleren van histamine. De meerderheid van de patiěnten met astma vertoonde een atopisch beeld. De diagnose COPD werd gesteld, wanneer de patiènt dyspnoe vertoonde, die niet noemenswaardig veranderde gedurende een observatieperiode van enkele maanden. De gegevens hierover werden verkregen van de verwijzend arts. Verder diende de FEV, na bronchusverwijding kleiner dan $70 \%$ van de voorspelde ECCS-waarde te zijn waarbij na toediening van salbutamol een reversibiliteit optrad van $<20 \%$.

Duur van de aandoening. Gevraagd werd naar het tijdstip waarop men zich realiseerde dat er ademhalingsmoeilijkheden waren of dat volgens anderen de aandoening zich voor het eersı kenbaar makkte door klachten.

3. Rookgedrag. Het rookgedrag werd geïnventariseerd omdat dat langdurig roken een belangrijke factor blijkt te zijn bij het ontstaan en de progressie van chronische bronchitis en emfyseem (Fletcher et al., 1976). Tijdens het opnamegesprek bij de arts werd de patiënt gevraagd naar zijn rookverleden. De variabele wordt uitgedrukt in het aantal pakjaren voorafgaand aan opname. Eén pakjaar wordt gedefinieerd als één pakje van 20 sigaretten per dag gedurende één jaar.

4. Functionele kenmerken. Hieronder vallen de ervaren beperkingen in dagelijkse activiteiten en de ervaren kortademigheid tijdens activiteiten en gedragingen.

De ervaren beperking in dagelijkse activiteiten werd geĩnventariseerd met behulp van de Dagelijkse Aktiviteiten Lijst, de DAL (Huisman, 1982; Kaptein et al. 1987d). Het betreft een zelfrapportage-vragenlijst met 11 uitspraken die betrekking hebben op beperkingen in zorgaktiviteiten, alsook op aan het dagelijks leven inherente inspanningsaktiviteiten, zoals traplopen en ten slotte beperkingen in het huishouden en/of de beroepssfeer. De DAL-score heeft een bereik van 0 tot en met 11. Hoe lager de somscore, des te minder beperkingen worden ervaren.

Ervaren kortademigheid werd geînventariseerd door middel van een vertaling van de dyspnoeschaal van de 'Chronic Respiratory Disease Questionnaire' van Guyatt en medewerkers (1987a). Op deze lijst geeft de patiënt weer in hoeverre hij/zij zich kortademig voelt tijdens gedragingen en activiteiten. De lijst bestaat uit 26 items, die worden gescoord op een 5-puntsschaal (I= 'heel kortademig'; $5=$ 'helemaal niet kortademig', hetgeen betekent dat een hoge score op deze lijst gunstig is). Voorbeelden van items zijn: aankleden, een wandeling maken, boosheid, praten, huishoudelijk werk doen. 
5. Psychologische kenmerken. Hieronder worden persoonlijkheidskenmerken, psychische klachten, de houding ten opzichte van de aandoening (schaamte, optimisme) en de angst bij benauwdheid gerekend.

Persoonlijkheidskenmerken werden gemeten met behulp van de Nederlandse Persoonlijkheidsvragenlijst (NPV, Luteijn et al., 1985), een lijst die bekend staat als meetinstrument met goede psychometrische eigenschappen. De lijst bestaat uit 133 vragen, waarvan de antwoorden bijdragen aan de ruwe score van een van de volgende zeven subschalen: Inadequatie, Sociale Inadequatie, Rigiditeit, Verongelijktheid, Zelfgenoegzaamheid, Dominantie en Zelfwaardering. De patiënt heeft bij de beantwoording van de vragen de mogelijkheid om aan te geven of de genoemde uitspraak wel of niet op hem of haar van toepassing is. Dit geschiedt door de respectievelijke antwoordmogelijkheden 'juist' of 'onjuist' te omcirkelen. Bij twijfel bestaat de mogelijkheid om een vraagteken te omcirkelen. Voor de bepaling van de emst van de ruwe score zijn normtabellen beschikbaar.

De handleiđing beschrijft de betekenis van de schalen als volgt: 'Personen die hoog scoren op de Inadequatieschaal (IN), geven daarmee te kennen dat ze zich gespannen, depressief en labiel voelen. Hiermee gaan vaak gevoelens van onzekerheid, somberheid en moedeloosheid gepaard. Laagscoorders zeggen daarvan geen last te hebben en worden gekenmerkı door het goed kunnen incasseren van legenslagen en zijn relatief evenwichtig en stabiel. Hoogscoorders op de Sociale Inadequatieschaal (SI) beschouwen zich als incompetent in contacten direkt met anderen; ze voelen zich geremd en verlegen. Laagscoorders treft men aan bij mensen die zeggen goed met anderen overweg te kunnen: ze zeggen gemakkelijk te praten en voelen zich open, vlot en sociabel. Personen met hoge scores op de Rigiditeitsschaal $(R G)$ houden van een strak planmatige aanpak in hun doen en laten en vinden het moeilijk om terug te komen op gewoonten en oplossingsmethoden. Laagscoorders worden meer gekenmerkt door een flexibele instelling en het zoeken naar nieuwe oplossingsmethoden. Hoogscoorders op de Verongelijktheidsschaal (VE) geven te kennen erg wantrouwend, zo niet vijandig tegenover anderen te staan. Zij zullen geneigd zijn hiervan blijk te geven door direct kommentaar te geven, intolerant en ongeduldig te zijn. Laagscoorders daarentegen kunnen in het algemeen goed naar anderen luisteren, zijn tolerant, vriendelijk en begrijpend. Personen die hoog scoren op de Zelfgenoegzaamheidsschaal (ZE), zeggen tevreden over zichzelf te zijn en weinig of geen boodschap te hebben aan anderen en hun problemen. Laagscoorders vinden van zichzelf dal ze anderen willen begrijpen en helpen alsook zich in anderen willen inleven. Hoogscoorders op de Dominantieschaal ( $D O)$ spreken hun voorkeur uit voor het geven van leiding; ze zeggen overwicht op anderen te hebben. Ze willen andere mensen stimuleren, hebben zelfventrouwen en en zullen zich actief in een groep gedragen. Laagscoorders daarentegen zullen eerder doen wat anderen zeggen, zich afhankelijk opstellen en zich passief in een groep gedragen. Personen die hoog scoren op de Zelfwaarderingsschaal $(Z E)$, hebben vrede met hun werk en bezigheden, ervaren weinig of geen onderscheid tussen wat ze zijn en wat ze graag zouden willen zijn en geven te kennen optimistisch van aard te zijn. Laagscoorders geven aan dergelijke gevoelens niet te hebben en worden meer gekenmerkt door pessimisme, somberheid en gebrek aan vitaliteit' (Luteijn et al., 1985).

Psychische klachten worden gemeten met de Symptom Checklist-90 (SCL-90; Arrindell et al., 1986). De lijst blijkt goede psychometrische eigenschappen te bezitten. De SCL-90 wordt omschreven als een multidimensionele schaal, die als toestands-meting op betrouwbare en kwantitatieve wijze een substantieel deel van relevante psychopathologische dimensies meetbaar maakt. Bij de beantwoording van de vragen beoordeelt de patiënt zelf, op een vijfpuntsschaal, de mate waarin hij/zij 'helemaal niet' (1), 'een beetje' (2), 'nogal' (3), 'tamelijk veel' (4), of 'heel erg' (5) last had van de genoemde klacht gedurende de afgelopen week, inclusief vandaag. De lijst bestaat uit negen subschalen, te weten: I. Agorafobie, 2. Angst, 3. Depressie, 4. Somatische klachten, 
5. Insufficièntie van denken en handelen, 6. Wantrouwen en Interpersoonlijke Sensitiviteit, 7. Hostiliteit, 8. Slaapproblemenen, 9. Totaalscore.

Volgens de omschrijving van de handleiding gaat het bij Agorafobie om een alles doortrekkende en disproportionele reactie van vrees in open ruimten, in openbare gelegenheden en bepaalde plaatsen. waarbij de persoon zich zwak voel, bang is niet op een vertrouwde ander te kunnen steunen, of bang is de zelfbeheersing te verliezen. De Angst-dimensie wordt gevomnd door klachten of symptomen die klinisch gesproken met een hoog angstniveau samenhangen. Het betreft vooral klachten die samenhangen met een verhoogde vegetatieve arousal, algemene symptomen van zenuwachtigheid, spanning, alsook meer specifieke symptomen als paniekaanvallen en rusteloosheid. Als cognitieve componenten kunnen onheilsgevoelens en angstige gedachten en voorstellingen gelden. De dimensie kan vooral worden opgevat als een aanduiding van gegeneraliseerde angst. De Depressieschaal omvat een groot aantal symptomen dat gewoonlijk bij het klinisch syndroom 'depressie' wordt opgemerkt. In de schaal zijn vooral symptomen met betrekking tot neerslachtige stemming. onvermogen om te genieten, verlaagde zelfwaardering, gedachten van schuld, hopeloosheid en dood en zelfmoord, alsmede lichamelijke aspecten zoals verlies van eetlust, gebrek aan energie en verminderde sexuele interesses. De dimensie Somatische klachten weerspiegelt klachten die met een algemeen gevoeld lichamelijk disfunctioneren samenhangen. Hierbij horen klachten die sterk samenhangen met het autonome systeem (ademhaling, hart) en klachten die meer met het spierstelsel (hoofdpijn, spieren, rug) te maken hebben. Ook somatische equivalenten van angst zijn aanwezig. De handleiding geeft verder aan dat het in het algemeen een verzameling symptomen betreft die vaak wordt gemeld bij functionele problemen, alhoewel een lichamelijke afwijking als grond nooit mag worden uitgesloten. De dimensie Insufficiëntie van denken en handelen richt zich vooral op gedachten, impulsen en problemen bij het uitvoeren van gedragingen die als dwingend en ondanks de eigen wil voorkomend worden ervaren. Vooral problemen in het cognitief functioneren staan centraal. In het algemeen verzamelt de schaal Wanirouwen en Interpersoonlijke Sensitiviteit symptomen die een grondtoon van onvrede met het zelf in relatie met andere mensen bevatten. Deze onvrede kan zowel naar buiten worden geprojecteerd, waarbij een paranoïde-vijandige houding ten opzichte van derden op de voorgrond staat, alsook worden ervaren als een gevoel van persoonlijke inadequatie en inefficiëntie in het contact met anderen. De Hostiliteitschaal geeft gedachten, gevoelens of gedragingen weer die kenmerkend zijn voor de negatieve gemoedstoestand van woede. Deze dimensie wordt gekenmerkt door aspecten van agressie, geïrriteerdheid, woede en ressentiment. De score op de dimensie Slaapproblemen drukt de mate uit waarin de patiënt moeite heefi met inslapen en/of doorslapen, en/of last heeft met een onrustige of gestoorde slaap' (Arrindell et al., 1986).

De houding ten opzichte van de aandoening is eveneens een in dit onderzoek gemeten psychologisch kenmerk. Dit geschiedde met de Respiratory Illness Opinion Survey (RIOS), een lijst samengesteld door Staudenmayer et al. (1978). Twee schalen werden gebruikt, te weten de schaal die 'optimisme" meet, dat wil zeggen de mate waarin de patiënt een positieve kijk heeft weten te verkrijgen ten opzichte van zijn mogelijkheden de aandoening de baas te zijn, en de schaal die 'schaamte' meet, de mate waarin de ademhalingsmoeilijkheden door de patiënt worden beschouwd als een psychologische nederlaag en hem het gevoel geeft anders te zijn dan anderen. De schaal die schaamte meet bevat zes items; de schaal die optimisme meet bevat vijf items. Beide schalen zijn 5puntsschalen. In Nederlands onderzoek onder Cara-patiënten die klinisch en poliklinisch werden behandeld, bleken deze twee schalen een voorspellende waarde te hebben met betrekking tot het resultaat van de medische behandeling (onder andere kans op ziekenhuisopname, opnameduur en ernst. van de medicatie) (Kaptein, 1982). 
Angst bij benauwdheid werd gemeten met de 'panic-fear'-schaal van de Asthma Symptom Checklist (ASC), geconstrueerd door Kinsman et al. (1973). De totale lijst bestaat uit vier subschalen van elk 10 items: panic-fear symptomatologie, geirriteerdheid, hyperventilatie en luchtwegobstructie, waarvan in dit onderzoek alleen de schaal die de angst bij benauwdheid (panic-fear) meet werd gebruikt. De items op deze schaal geven specifieke, situationele symptomen van angst weer, die de patiènt kan ervaren gedurende kortademigheid. Patiënten met een hoge score op deze lijst geven daarmee te kennen te reageren met een nauwlettende bezorgdheid omtrent hun ademhalingsmoeilijkheden, terwijl patiënten met een lage score juist geneigd zijn te reageren met een gebrek aan bezorgdheid hieromtrent (Dirks, 1978).

6. Sociale kenmerken. Hieronder vallen de ervaren sociale steun en de ervaren mogelijkheid om met de directe omgeving (gezinsleden en vrienden) te kunnen praten over de longaandoening. Beide kenmerken werden gemeten met de sociale ondersteuningslijst (Van den Borne et al., 1983). De lijst die ervaren sociale steun meet bestaat uit 16 items die elk een affectieve ervaring in het contact met een ander uitdrukken. De patiënt wordt gevraagd op een 4-puntsschaal ( $1=$ nooit; 2 = vaak) aan te geven hoe vaak hij of zij een dergelijke ervaring gedurende de afgelopen twee weken had. De lijst die 'kunnen praten over de aandoening' meet bestaat uit negen items waarop de patiënt op een 4-puntschaal moet aangeven in hoeverre hij/zij het eens is met de uitspraak (1 $=$ zeer mee eens, 4 = helemaal niet mee eens). De items hebben elk betrekking op de ervaren gelegenheid om met vrienden of familie over de aandoening te praten en drukt als zodanig een aspect uit van sociale steun.

7. Medische consumptie. De medische consumptie omvat in dit onderzoek de volgende variabelen: medicatiegebruik in verband met ademhalingsmoeilijkheden, frequentie van het artsenbezoek (huisarts en/of specialist) alsmede frequentie en duur van de ziekenhuisopnamen in verband met Cara.

Medicatiegebruik werd geïnventariseerd door de patiënt te vragen gedurende drie weken een dagboek bij te houden van zijn of haar medicijngebruik. Dit geschiedde voor opname, na ontslag en tijdens de follow-up meetmomenten. Hierin werden de volgende groepen van medicijnen onderscheiden:

- Theofylline-preparaten, anticholinergica en $\beta_{2}$-sympaticomimetica, medicijnen met als doel het verminderen en opheffen van benauwdheidsklachten door verwijding van de luchtwegen.

- Antihistaminica, een groep van medicijnen die luchtwegvernauwende stoffen, zoals histamine, minder werkzaam maken.

- Cromoglycaten, ter voorkoming van benauwdheidsklachten ten gevolge van inspanning en allergie.

- Corticosteröden, zowel in vaste vorm (oraal) als door inhalatie in te nemen. De middelen worden voorgeschreven om onstekingsreacties en late allergiereacties tegen te gaan.

- Mucolytica, een medicijn waarmee het vloeibaar maken van taai slijm wordt beoogd.

- Antibiotica, voorgeschreven om bacteriële luchtweginfecties tegen te gaan.

De frequentie van de bezoeken aan de huisarts en/of de specialist werd geïnventariseerd dooi de arts in Nederland hiervan opgave te laten doen. Deze werden hiertoe telefonisch benaderd. Frequentie en duur van ziekenhuisopnamen in verband met de Cara werd op gelijke wijze als het artsbezoek nagevraagd bij de verwijzend arts in Nederland. Over het algemeen werden de gevraagde gegevens door de artsen bereidwillig verstrekt. Teneinde de betrouwbaarheid te verhogen werd telkens, nadat eerst de vraag tot verstrekking van de gegevens was gesteld, een telefonische afspraak gemaakt waarin gelegenheid bestond de gegevens door te gegeven aan de hand van het patiëntendossier. Ook het feit dat zowel navraag werd gedaan bij de huisarts als bij de specialist heeft tot de betrouwbaarheid bijgedragen. 


\subsubsection{Afhankelijke en onafhankelijke variabelen en statistische procedure per vraagstelling}

De eerste onderzocksvraag luidt: Wat zijn kenmerken van patiēnten die worden opgenomen in het NAD, gemeten aan longfunctie, rookgedrag, aspecten van medische consumptie en aspecten van kwaliteit van leven?

De longfunctie ( $\mathrm{FEV}_{1}$ en VC, beide uitgedrukt in percentage van de norm en bepaald vór en nà een bronchusverwijder), het aantal pakjaren, medische consumptie (de frequentie van huisartsen specialistbezoeken, ziekenhuisopnamen en ziekenhuisdagen en de omvang van het medicaticgebruik in verband met de Cara-klachten) en de kwaliteit van leven (het functionele, psychologische en sociale aspect) worden beschreven.

De statistische procedure bij de eerste onderzoeksvraag. Voor de beschrijving van de genoemde kenmerken worden gemiddelden en de standaarddeviaties bepaald. Bij scheef verdeelde scores wordt tevens de mediaan gegeven. Inzake de vragenlijsten, waarvan de betrouwbaarheid niet voldoende bekend is wordt de interne consistentie bepaald aan de hand van de Cronbach's $\alpha$. Als onderdeel van deze eerste onderzoeksvraag wordt tevens nagegaan of er verschillen bestaan tussen de gemiddelden van subgroepen van de onderzoekspopulatie. Tevens wordt met betrekking tot de scores op enkele variabelen nagegaan of er verschillen zijn tussen gemiddelden van de onderzoekspopulatie en van andere populaties. Hiertoe worden respectievelijk t-tests voor groepen van waamemingen (bijvoorbeeld diagnose of geslacht) en gepaarde t-tests uitgevoerd.

De tweede onderzoeksvraag luidt: Wat is het beloop van de scores op kenmerken die aspecten van kwaliteit van leven en medische consumptie uitdrukken, gemeten over de meetmomenten opname, ontslag, 6 maanden en 12 maanden na ontslag?

De beantwoording van de vraag naar het beloop van kenmerken geschiedt aan de hand van de volgende variabelen: huisarts- en longspecialistbezoek, ziekenhuisopnamen, ziekenhuisdagen, oraal en inhalatie corticosteroïdgebruik (medische consumptie); ervaren beperkingen in dagelijkse activiteiten en ervaren kortademigheid (functioneel aspect van kwaliteit van leven); schaamte, optimisme, angst bij benauwdheid, inadequatie, sociale inadequatie, zelfwaardering, angst, agorafobie en depressie (psychologisch aspect van kwaliteit van leven); ervaren sociale steun en kunnen praten over de aandoening met familie en vrienden (sociale aspect van kwaliteit van leven).

De statistische procedure bij de tweede onderzoeksvraag. Allereerst wordt nagegaan of er door de uitval van respondenten sprake is van een responsbias. Daartoe worden voor wat betreft de continue variabelen de scores bij opname van degenen die op het moment van 12 maanden na ontslag wel en niet responderen, door middel van de t-test of de Mann-Whitney-test voor onafhankelijke steekproeven met elkaar vergeleken. Inzake de discontinue variabelen wordt gebruik gemaakt van kruistabellen en getoetst door middel van de $\mathrm{Chi}^{2}$.

Voor de beschrijving van de kenmerken per meetmoment worden gemiddelden, standaarddeviaties en frequenties bepaald. Om vast te stellen of er verschillen zijn tussen de scores van de follow-up meetmomenten en de baselinescores wordt bij de normaal verdeelde scores parametrisch (t-toets) en bij de niet normaal verdeelde scores non-parametrisch (Mann-Whitney) getoetst.

De derde onderzoeksvraag luidt: Hoeveel patiënten zijn, gemeten 12 maanden na ontslag, in vergelijking met het moment van opname verbeterd, verslechterd, of onveranderd op de aspecten van medische consumptie en kwaliteit van leven?

De statistische procedure bij de derde onderzoeksvraag. Ten einde deze vraag te beantwoorden worden de hiema volgende stappen gezet. Allereerst worden de scores bij opname naar tertielen 
in drie categorieën ingedeeld. Daar waar tertielindeling niet geheel mogelijk blijkt wordt de cut-off die bepaalt in welke categorie de score van een patiênt valt, vastgesteld aan de hand van de waarde die zo dicht mogelijk bij een tertielindeling ligt. Deze indeling wordt tevens op de scores van 12 maanden na ontslag toegepast. Wanneer de aldus verkregen scores bij opname en die van 12 maanden na. ontslag van elkaar worden afgetrokken wordı door middel van kruistabellen bekeken hoeveel patiënten in de categorieën terecht komen die respectievelijk verwijzen naar een verhoogde score, dezelfde score of een verlaagde score. Voor wat betreft de aspecten van medische consumptie zijn de tertielindelingen bepaald over het deel van de onderzoekspopulatie dat bij de beginmeting en/of bij de eindmeting een score had van $>0$. In tabel 3.2. wordt het door middel van de tertielindeling vastgestelde scorebereik op de onderzoeksvariabelen weergegeven.

Tabel 3.2. Scorebereik na tertielindeling van scores op aspecten van medische consumptie, functionele, psychologische en sociale kenmerken

\section{categorie}

$1 \quad 3$

\section{MEDISCH/SOMATISCH}

longfunctie (FEV, \% van de norm)

MEDISCHE CONSUMPTIE

$\begin{array}{ll}\text { huisartsconsulten } & 0-2 \\ \text { specialistconsulten } & 0-5 \\ \text { ziekenhuisopnamen } & 0 \\ \text { ziekenhuisdagen } & 0-10 \\ \text { corticosteroiden } & \\ \quad \text { oraal } & 1 \\ \text { inhalatie } & 0-750\end{array}$

$0-2-3-6$

$\geq 7$

$6-7$

$\geq 8$

$\begin{array}{lll}0 & 1 & \geq 2 \\ 0-10 & 11-29 & \geq 30\end{array}$

inhalatie

\section{FUNCTIONELE KENMERKEN}

ervaren beperkingen dagelijkse activiteiten 0-5

kortademigheid.

\section{9-54}

\section{$0=11$}

$0-7$

$0-21$

$10-14$

7

agorafobic

depressie

$10-24$

schaamte

6-11

angsil bij benauwdheid
6

55-73

12-2!

8-14

22-26

15-21

8-11

25-31

12-19

23-29

48-51

22-26 $\geq 7$

$\geq 74$

\section{SOCIALE KENMERKEN}

ervaren sociale steun

De vierde en vijfde onderzoeksvragen betreffen die naar determinanten van effecten van een opname in het NAD.

De vierde vraagstelling luidt: Wat zijn determinanten van verbetering en van verslechtering op aspecten van medische consumptie en op de ervaren beperkingen in dagelijkse activiteiten. 
De viffde vraagstelling luidt: In hoeverre hangt het veranderd zijn (in gunstige zin) op enkele psychologische en longfunctiekenmerken samen met de verbeteringen op de ervaren beperkingen in dagelijkse activiteiten en op enkele aspecten van medische consumptie, te weten de frequentie en de duur van ziekenhuisopnamen vanwege Cara en het oraal corticosteroidgebruik?

Hiema wordt de keuze voor de afhankelijke variabelen van deze beide onderzoeksvragen onderbouwd. Vervolgens worden de onafhankelijke variabelen van deze laatste twee onderzoeksvragen afzonderlijk besproken.

De afhankelijke variabelen bij de vierde en de vijfle onderzoekswraag. Deze beide vraagstellingen hebben betrekking op de uitkomstvariabelen 'ervaren beperkingen in dagelijkse activiteiten' en de aspecten van medische consumptie.

Bij de keuze van deze effectmaten is in de eerste plaats uitgegaan van de definitie van longrevalidatie. Hierin wordt naast het stabiliseren van de pathofysiologische en psychopathologische aspecten van de aandoening als belangrijk doel genoemd het begeleiden van de patiènt naar en zo hoog mogelijk functioneel capaciteitenniveau. Dit laatste wordt in dit onderzoek vertaald naar het kunnen verrichten van algemene dagelijkse activiteiten, hetgeen het zelfstandig functioneren van de patięnt ten goede komt. Ook de literatuur over longrevalidatic en over astmacentra noemt het verbeteren van de functionele mogelijkheden van de CARA-patiënt als het belangrijkste doel van longrevalidatie (onder andere: Petty et al., 1969; Petty, 1977; Tiep, 1993; Casaburi, 1993; Carter, 1986; College voor Ziekenhuisvoorzieningen, 1990; Van den Brink, 1989; Make, 1986; Hodgkin, 1986, 1990). In dit onderzoek wordt dit geoperationaliseerd door de variabele 'ervaren beperking in dagelijkse activiteiten'. Een afname van de score op deze afhankelijke variabele wordt als een gunstig effect beschouwd.

In de tweede plaats is bij het bepalen van effectmaten uitgegaan van de gedachte dat de indicatie voor longrevalidatie in het NAD in veel gevallen een voortvloeisel is uit een hoge medische consumptie in de periode voorafgaand aan opname. Een belangrijk doel van Iongrevalidatie in het NAD is dan ook om tot een reductie hiervan te komen. Toch ligt dit voor de verschillende in dit onderzoek gemeten aspecten van de medische consumptie niet eenduidig. Terwijl afname van het aantal ziekenhuisopnamen en het aantal ziekenhuisdagen en afname van het gebruik van orale corticosteroïden als gunstige effecten worden beschouwd, ligt dit anders voor het aantal specialist- en huisartsbezoeken. Immers, in sommige gevallen kan een toename van het aantal huisarts- of specialistbezoeken als een gunstige ontwikkeling worden gezien, bijvoorbeeld om een afname van het aantal en de duur van ziekenhuisopnamen te ondersteunen. De verschillende aspecten van medische consumptie hebben zeer waarschijnlijk een interdependent karakter, waardoor niet zonder meer gesproken kan worden van een gunstig effect bij een geconstateerde afname van het aantal specialist- en huisartsbezoeken. Volgens dezelfde redenering hoeft een toename van het aantal huisarts- of specialistbezoeken geen verslechtering te betekenen. Het resultaat van het determinantenonderzoek moet in het licht van deze redenering worden bezien. Bij de vierde onderzoeksvraag zijn het huisarts- en specialistbezoek wèl, bij de vijfde onderzoeksvraag is het nièt als afhankelijke variabele opgenomen.

Bij de aspecten van medische consumptie werd alleen dàt cohort tot de onderzoeksgroep gerekend dat bij baselinemeting of tijdens het moment van 12 maanden na ontslag respectievelijk minimaal één eenheid corticosteroïden, of één ziekenhuisopname dan wel artsbezoek had.

De onafhankelijke variabelen betreffende de vierde onderzoeksvraag. De volgende variabelen worden als mogelijke determinanten opgevoerd van de vierde vraagstelling: 
- De baseline-score van de betreffende afhankelijke variabele. Voor de ervaren beperkingen in dagelijkse activiteiten en de orale corticosteroïden betreft dit respectievelijk de score bij opname en het aantal eenheden à $5 \mathrm{mg}$. op het moment van drie weken vór opneming, terwijl dit voor de variabelen huisartsbezoek, specialistbezoek, ziekenhuisopnamen en ziekenhuisdagen de frequentie gedurende het jaar voorafgaand aan opname betreft.

- Sociodemografische kenmerken: geslacht, leefijid en burgerlijke staat.

- Longfunctie (FEV, als \% van de norm, vastgesteld vóór medicatie), diagnose en duur van de aandoening, gemeten bij opname.

- Pakjaren. Het gaat bij deze variabele om de mate waarin patiënten in hun leven hebben gerookt. - Angst bij benauwdheid, gemeten bij opname. Verondersteld wordt dat de angst bij benauwdheid een belangrijk obstakel vormt in het motiveren van de patiènt tot het verrichten van inspanning en activiteiten. Deze angst kan derhalve leiden tot vermijding van activiteiten, hetgeen mogelijk tot uitdrukking komt in de score op ervaren beperkingen in dagelijkse activiteiten en de aspecten van de medische consumptie. Anderzijds zou een te geringe mate van angst eveneens kunnen leiden tot meer medische consumptie, een hypothese die binnen de eeder genoemde Denverse groep van onderzoekers werd getoetst.

- Kortademigheidsklachien. Ook de ervaring van kortademigheid kan mogelijk van invloed zijn op de veranderingen in ervaren beperkingen in dagelijkse activiteiten en medische consumptie. Het is de verwachting dat patiènten die qua ziekenhuisopnamen, ziekenhuisdagen, oraal corticosteroïdgebruik en ervaren beperkingen in dagelijkse activiteiten verbeteren, minder kortademigheidsklachten rapporteren bij opname.

- Psychische Klachten komen bij Cara-patiënten veelvuldig voor. Agle et al. (1973) komen op grond van onderzoek tot de conclusie dat patiënten die als gevolg van longrevalidatie verteteren, bij aanvang van het longrevalidatieprogramma in minder emstige mate psychiatrische symptomen vertonen dan patiënten die de behandeling minder succesvol hadden afgerond. Of deze bevinding, waamaar in de literatuur veelvuldig wordt verwezen, eveneens van toepassing is op de populatie die in het NAD wordt opgenomen, zal in dit onderzoeksdeel worden nagegaan. Daarbij zullen de subschalen 'Inadequatie', 'Sociale Inadequatie' en 'Zelfwaardering' van de Nederlandse Persoonlijkheidvragenlijst en de subschalen 'Angst' en 'Depressie' van de SCL-90 worden gebruikt.

- Schaamie. De veronderstelling hierbij is dat patiënten die zich schamen over hun aandoening. met hun Cara minder adequaat omgaan, hetgeen mogelijk gevolgen heeft voor de medische consumptie en de ervaren beperkingen in dagelijkse activiteiten.

- Sociale ondersteuning. Uit verschillende studies blijkt dat sociale steun een gunstig effect kan hebben op gezondheid en op diverse met gezondheid samenhangende kenmerken, zoals de psychologische toestand (Monroe et al. 1986), de medische consumptie (Pilisuk et al., 1987), algemene morbiditeit (Blake et al., 1986; McKay et al., 1985) en mortaliteit (Appels et al., 1988; Ruberman et al., 1984). In dit onderzoeksdeel zal worden onderzocht in hoeverre de 'ervaren sociale steun' en 'kunnen praten over de aandoening met familie en vrienden' een voorspellende waarde hebben ten opzichte van de gekozen afhankelijke variabelen.

De onafhankelijke variabelen betreffende de vijfde onderzoeksvraag. Als onafhankelijke variabelen betreffende de vijfde vraagstelling wordt gekozen voor veranderingen op psychologische variabelen, te weten op angst, agorafobie, depressie, schaamte en angst bij benauwdheid en verandering op longfunctie, te weten de $\mathrm{FEV}_{1}$.

Voor wat betreft de genoemde psychologische kenmerken wordt aan de hand van de scores bij 12 maanden na ontslag bepaald, of er een verbetering is opgetreden ten opzichte van opname. 
Aangaande de longfunctic is dit het verschil tussen het moment van opname en het moment van ontslag. Nagegaan wordt of verbeteringen op deze onafhankelijke variabelen een samenhang vertonen met verbeteringen op het vlak van de ervaren beperkingen in dagelijkse activiteiten en de medische consumptie.

De keuze voor deze psychologische variabelen is hierop gebaseerd dat deze beschouwd worden als belangrijke probleemgebieden waarop klinisch psychologen van het NAD veelal hun interventies richten.

De statistische procedure bij de vierde onderzoeksuraag. Bij de afhankelijke variabelen ziekenhuisopnamen, ziekenhuisdagen, oraal corticosteroìdgebruik en ervaren beperkingen in dagelijkse activiteiten wordt ervan uitgegaan dat een verlaging van de score een uitdrukking is van een verbetering, terwijl een onveranderde of verhoogde score dat niet is, In overeenstemming hiermee betekent een verhoging van de score op deze afhankelijke variabelen een verslechtering en een onveranderde of een verlaagde score niet.

Voorafgaand aan de analyses wordt een dichotomisering van de scores toegepast. Met betrekking tot de vraag naar determinanten van een verbetering ontstaat door dichotomisering de groep die is verbeterd en de groep die onveranderd is of is verslechterd. Aangaande de vraag naar de determinanten van een verslechtering ontstaat na dichotomisering van de scores de groep die is verslechterd en de groep die onveranderd of beter heeft gescoord. Het betreft hier telkens veranderingen van scores nadat categorisering in tertielen heeft plaatsgevonden (zie hiervoor de statistische procedure bij de derde onderzoeksvraag). Inzake de afhankelijke variabelen huisartsbezoeken en specialistbezoeken werd een driedelige score gehandhaafd, aangezien cen verlaagde frequentie van huisarts- en specialistbezoek niet noodzakelijk een verbetering en een verhoogde frequentie niet noodzakelijk een verslechtering inhoudt.

Om na te gaan of de scores op de onafhankelijke variabelen verschillen voor wat betreft de scorecategorieën van de afhankelijke variabelen werd variantieanalyse uitgevoerd. Op de onafhankelijke variabelen met continue scores werd als toetsingseenheid de F-ratio bepaald. Betreffende de discontinue determinantvariabelen (diagnose, geslacht, burgerlijke staat) werd getoetst aan de hand van de $\mathrm{Chi}^{2}$. Om na te gaan welke variabele het belangrijkste is werd correlatie- en multiple regressieanalyse toegepast.

De statistische procedure bij de vijfde onderzoeksvraag. Teneinde te bepalen of een patiënt al of niet is verbeterd op de gekozen psychologische variabelen werd de 'reliable change index' (RC) bepaald, een veelal bij psychotherapie-effectonderzoek gebruikte statistische methode voor het vaststellen van de klinische significantie van verschilscores. Dit geschiedde aan de hand van de volgende formule: $R C=\left(x_{2}-x_{1}\right) / S_{\text {diff, }}$ waarbij $x_{1}$ de score vertegenwoordigt bij opname en $x_{2}$ de score van 12 maanden na ontslag. $S_{\text {diff }}$ is de standaardfout van het verschil tussen deze twee scores en kan direct uit de standaard meetfout $\left(\mathrm{S}_{\mathrm{F}}\right)$ worden berekend, volgens de volgende formule: $S_{\text {diff }}=\sqrt{2\left(S_{E}\right)^{2}}$. Hierbij beschrijft $S_{\text {diff }}$ de spreiding van de verdeling van de veranderingsscores die kunnen worden verwacht als er geen echte verandering optreedt. Een $\mathrm{RC}>1,96$ wordt onwaarschijnlijk geacht $(p<.05)$ zonder dat een echte verandering in gunstige zin optreedt (Jacobson et al., 1984). Een patiënt die op basis van de aldus bepaalde 'reliable change index' op de betreffende psychologische variabele een score had van RC $>1,96$ werd ingedeeld in de groep die is verbeterd. Vervolgens werd met variantieanalyse nagegaan of het al dan niet verbeterd zijn op de onafhankelijke variabelen samenhing met de verschilscores op de afhankelijke variabelen. 


\subsection{Onderzoeksprocedure}

De gegevens bij opname werden in drie fasen verzameld. Het eerste meetmoment vond plaats. ongeveer drie weken voor de opneming in het NAD. De patiënt kreeg een boekje thuisgestuurd met verschillende vragenlijsten en een dagboekvorm voor het bijhouden van de medicatie. In de inleiding hiervan werd uitdrukkelijk vermeld dat de beslissing orntrent een opname reeds was gevallen opdat de antwoorden zo weinig mogelijk door dat aspect zouden worden beïnvloed. De patiënt werd in de gelegenheid gesteld zijn deelname aan onderzoek te weigeren. Er werd bijvermeld dat dit geen consequenties zou hebben voor zijn of haar behandeling.

Het boekje bevatte vragen over variabelen waarvan het van belang werd geacht dat ze, voor een juiste voorstelling van zaken, beantwoord werden in de thuisomgeving. Het betrof vragen over de ervaren beperkingen in dagelijkse activiteiten, ervaren kortademigheid bij activiteiten en gedragingen, de ervaren sociale ondersteuning en de vraag naar het medicatiegebruik. De patiënten werden in deze fase in de gelegenheid gesteld telefonisch om verduidelijking te vragen. Zij konden zich hiertoe in verbinding stellen met het bureau 'maatschappelijk werk' te Gouda, waarvoor overdag een telefonisch spreekuur bestond. Tevens werd de patiënt in de gelegenheid gesteld de onderzoeker te bellen in het NAD.

De afname van de resterende lijsten in deze meetperiode (NPV, SCL-90, ASC, RIOS) vond gedurende de iweede, derde of vierde dag (afhankelijk van een eventueel tussenliggend weekend) van opname, groepsgewijs plaats. De onderzoeker stelde zichzelf aan de patiënt voor en zette het doell van het onderzoek en de afname van de vragenlijsten uiteen. Er werd uitgelegd dat de antwoorden op de vragen zowel zouden worden gebruikt voor evaluatiedoeleinden als voor de individuele diagnostiek. Ruim aandacht werd besteed aan de instructie bij de verschillende vragenlijsten. De patiënten beantwoordden de vragenlijsten in aanwezigheid van de onderzoeker. Aangezien uit ervaring bekend was dat er met betrekking tot de invulling van deze vragenlijsten nog wel eens onduidelijkheden blijven bestaan, bleef de onderzoeker aanwezig om de patiènten te begeleiden bij het doorwerken van de lijsten. Wanneer alle vragenlijsten waren gescoord werd de patiènt in de gelegenheid gesteld een gesprek te hebben met de onderzoeker over de testscores. Hiervoor werd over het algemeen een half uur per patiënt besteed.

Tijdens de eerste of tweede dag van opname vond het longfunctieonderzoek plaats.

Bij ontslag werden wederom de vragenlijsten, die ook bij opname werden afgenomen, aan de patiènt voorgelegd. Om dezelfde reden als bij opname werden een aantal variabelen drie weken ná ontslag afgenomen. Dit geschiedde wederom in de vorm van een boekje. Verzocht werd deze na invulling te retoumeren.

Voor wat betreft de follow-up gegevens werden zes maanden en 12 maanden na ontslag opnieuw alle vragenlijsten aan de patiënt opgestuurd. Deze werden weer begeleid door een uitgebreide instructie waarbij opnieuw op de mogelijkheid werd gewezen bij vragen gebruik te maken van een speciaal ingesteld telefonisch spreekuur met het bureau maatschappelijk werk in Gouda of met de onderzoeker in het NAD.

Voor de verzameling van de gegevens van de medische consumptie in het jaar voorafgaand aan opname in het NAD werden in de periode rond opname de huisarts en de specialist telefonisch benaderd met het verzoek opgave te doen van het aanial consuiten en het aantal en de duur van eventuele ziekenhuisopnamen in verband met Cara. In de meeste gevallen werd eerst om verstrekking van de gegevens gevraagd en werd vervolgens een telefonische afspraak gemaakt waarin de betreffende gegevens zouden worden doorgegeven. Dit werd 12 maanden na ontslag herhaald. De vraag betrof dan de medische consumptie gedurende het jaar na ontslag uit het NAD. 


\subsection{Inleiding}

In dit hoofdstuk worden de resultaten beschreven met betrekking tot de eerste onderzoeksvraag: Wat zijn kenmerken van patiënten die worden opgenomen in het NAD, beschreven in termen van longfunctie, rookgedrag, aspecten van medische consumptie en aspecten van kwaliteit van leven? Na medische variabelen (diagnose en longfunctickenmerken) zal de medische consumptic in het jaar voorafgaand aan opname in het NAD worden weergegeven. Vervolgens komt een beschrijving van de populatie aangaande aspecten van kwaliteit van leven aan bod. Daarbij wordt de indeling gevolgd die werd voorgesteld door Van Knippenberg en De Haes (1988). $\mathrm{Zij}$ onderscheiden een functioneel, een psychologisch en een sociaal aspect aan het begrip 'kwaliteit van leven'.

\subsection{Medisch-somatische kenmerken}

In tabel 4.1, staan de gegevens vermeld betreffende de diagnose en de longfunctic. Laatstgenoemd kenmerk wordt uitgedrukt in percentages van de norm. De tabel laat zien, dat $24 \%$ van de onderzoekspopulatie astma had en $76 \%$ COPD. Bij onderverdeling naar geslacht bleek een grote meerderheid van de astmapopulatie uit vrouwen te bestaan, terwijl er een gelijke geslachtsverdeling bestond onder de COPD-groep.

In dezelfde tabel worden tevens de longfunctiewaarden beschreven. Het betreft waarden, vastgesteld zowel vó́r als nà toediening van een bronchusverwijder (salbutamol). De onderverdeling van deze kenmerken naar diagnose staan beschreven in tabel 4.2.. Uit deze tabel is op te maken dat het onderscheid tussen patiënten met astma en met COPD qua longfunctiekenmerken significant is voor wat betreft de Forced Expiration Volume in één seconde $\left(\mathrm{FEV}_{1}\right)$, vóor en ná medicatie en voor wat betreft de Vitale Capaciteit (VC) na medicatie. Verder blijki er een verschil te bestaan in reversibiliteit van de longfunctie iussen de astma-en de COPD-groep. De astmapopulatie had na toediening van de bronchusverwijder qua longfunctie een groter verschil (reversibiliteit) dan de COPD-populatie. Dit onderscheid bestaat per definitie. immers, de diagnose werd bepaald aan de hand van deze reversibiliteit van de $\overline{F E V}_{1}$ na toediening van salbutamol. De reversibiliteit van de $\mathrm{FEV}_{1}$ (\% nom) was voor de astmapopulatie gemiddeld $27,0 \pm 12,9$ (\% norm) en voor de COPD-populatie $8,9 \pm 8,5(\%$ norm $)(F=81.92 ; d f=131 ; p<.001)$. Betreffende de VC was de reversibiliteit voor de asimapopulatie $17,7 \pm 14,6$ en voor de COPD-populatie $8,1 \pm 15,0(F=9.54$; $d f=124 ; p<.01)$.

Wat het rookgedrag betreft bleek, dat het gemiddeld aantal pakjaren $8,2 \pm 12,3$ bedroeg. Voor de astmapopulatie gold een gemiddeld aantal van 4,3土7,0 pakjaren, terwijl dat voor de COPD-

\footnotetext{
'Verslag van een pilot-studie werd eerder gepubliceerd (Van der Schoot, T.A.W., Kaptein, A.A., Dekker, F.W., Lammers, W.L.M. \& Van den Brink, W.T J. Nederlands Tijdschrift voor Geneeskunde, 1988, 132, 1105-1 108).
} 
populatie $9,9 \pm 13,2$ bleek te zijn $(t=-3.26 ; d f=111.3 ; p<.001)$. Het verschil blijkt significant. De COPD-populatie heeft ruim twee maal zoveel gerookt als de astmapopulatie.

Eveneens significant is het verschil tussen het aantal rokers onder de mannen en de vrouwen (respectievelijk $11,3 \pm 12,4$ en $6,2 \pm 11,7 ; t=2,56$; $d f=144 ; p<.05$ ).

Tabel 4.1. Diagnose en longfunctiekenmerken ( $\%$ van de norm) van volwassen Cara-patiënten bij opname in het NAD

\begin{tabular}{|c|c|c|c|c|c|c|c|c|}
\hline \multirow{2}{*}{ 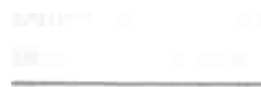 } & \multicolumn{3}{|l|}{ totaal } & \multicolumn{2}{|c|}{$\operatorname{man}$} & \multicolumn{3}{|c|}{ vrouw } \\
\hline & $N$ & $\%$ & & $N$ & $\%$ & $N$ & $\%$ & $\chi^{2}$ \\
\hline \multicolumn{9}{|l|}{ DIAGNOSE $(N=148)$} \\
\hline astma & 35 & 24 & & 9 & 26 & 26 & 74 & 708 \\
\hline COPD & 113 & 76 & & 58 & 51 & 55 & 49 & \\
\hline LONGFUNCTIE & $M$ & (SD) & $N$ & & $\min / \max$ & & & \\
\hline VC voor medicatie & 88,5 & $(23,5)$ & 131 & & $25,9 / 147,0$ & & & \\
\hline VC na medicatie & 99,3 & $(25,5)$ & 127 & & $24,5 / 198,0$ & & & \\
\hline FEV, voor medicatie & 60.9 & $(24,8)$ & 137 & & $17,1 / 130,0$ & & & \\
\hline FEV, na medicatie & 74.2 & $(27,5)$ & 134 & & $22,4 / 136,0$ & & & \\
\hline
\end{tabular}

" $p<01$

Tabel 4.2. Longfunctiekenmerken ( $\%$ van de norm) van volwassen Cara-patiènten bij onderverdeling naar astma en COPD

\begin{tabular}{lcccccccc}
\hline & \multicolumn{4}{c}{ astma } & \multicolumn{4}{c}{ COPD } \\
& $M$ & $(S D)$ & $N$ & & $M$ & $(S D)$ & $N$ \\
\hline VC voor medicatic & 92,8 & $(27,4)$ & 31 & & 87,2 & $(22,2)$ & 100 \\
VC na medicatic & 109,8 & $(23,8)$ & 30 & & 96,1 & $(25,3)^{*}$ & 97 \\
FEV, voor medicatic & 69,0 & $(18,1)$ & 32 & & 58,4 & $(26,1)^{\circ}$ & 104 \\
FEV, na medicatic & 94,3 & $(20,5)$ & 32 & & 67,9 & $(26,4)^{\cdots}$ & 102 \\
\hline
\end{tabular}

'p<.05; $" p<.01 ;{ }^{\cdots}{ }_{p<.001}$

Worden de longfunctiekenmerken van de mannen vergeleken met die van de vrouwen (tabel 4.3.) dan blijken de vrouwen over het algemeen een gunstiger $\mathrm{FEV}_{1}$ (\% van de norm) te vertonen dan de mannen.

Tabel 4.3. Longfunctiekenmerken ( $\%$ van de norm) van volwassen Cara-patiěnten bij opname in het NAD naar geslacht

\begin{tabular}{|c|c|c|c|c|c|c|}
\hline & \multicolumn{3}{|l|}{$\operatorname{man}$} & \multicolumn{3}{|c|}{ vrouw } \\
\hline & M & (SD) & $N$ & $M$ & $(S D)$ & N \\
\hline VC voor medicatie & 85.5 & $(24,6)$ & 63 & 91,4 & $(22,3)$ & 68 \\
\hline VC na medicatic & 95,9 & $(25.4)$ & 62 & 99.7 & $(25.9)$ & 66 \\
\hline FEV , voor medicatic & 53,7 & $(23,2)$ & 65 & 67,3 & $(24,5)^{\cdots}$ & 72 \\
\hline FEV, na medicatie & 64.2 & $(26,8)$ & 64 & 83.3 & $(25,0)^{\cdots \cdot}$ & 70 \\
\hline
\end{tabular}

".. $p<.001$ 


\subsection{Medische consumptiekenmerken}

Gebleken is dat de waarden op de variabelen die medische consumptie uitdrukken (behalve oraal corticosteroidgebruik) een scheve verdeling vertonen. Om die reden geven gemiddelde waarden mogelijk een vertekend beeld, waardoor in tabel 4.4. tevens de mediaan en het bereik van de waarden staan vermeld. Uit deze tabel blijkt dat in de periode van 1 jaar voor opname in het NAD, $83 \%$ van de totale onderzoekspopulatie de huisarts heeft bezocht (mediaan: 5,0 ). In diezelfde periode had $97 \%$ contacten met de longspecialist (mediaan: 6,0). Van de totale populatie bleek $74 \%$ zowel consulten bij de huisarts als bij de specialist te hebben gehad. Van de onderzoeksgroep had $61 \%$ één of meer ziekenhuisopnamen achter de rug (mediaan duur opname: 22,0 dagen).

Tabel 4.4. Medische consumptie vanwege Cara 1 jaar voorafgaande aan opname in het NAD

\begin{tabular}{|c|c|c|c|c|c|c|}
\hline & $N$ & 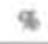 & M & $(S D)$ & mediaan & $\min / \operatorname{mas}$ \\
\hline \multicolumn{7}{|l|}{ huisartsconsulten $(\mathrm{N}=143)$} \\
\hline geen consulten & 24 & 17 & & & & \\
\hline wel consulten & 119 & 83 & 8.0 & $(12,0)$ & 5,0 & $1 / 102$ \\
\hline \multicolumn{7}{|c|}{ specialistconsulten $(N=137)$} \\
\hline geen consulten & 4 & 3 & & & & \\
\hline wel consulten & 133 & 97 & 7,1 & $(4,4)$ & 6,0 & $1 / 30$ \\
\hline \multicolumn{7}{|c|}{ ziekenhuisopnamen $(\mathrm{N}=122)$} \\
\hline geen opname & 55 & 39 & & & & \\
\hline wel opname(n) & 86 & 61 & 2,1 & $(1.4)$ & 2.0 & $1 / 6$ \\
\hline \multicolumn{7}{|c|}{ duur ziekenhuisopnamen (dgn.) $(\mathrm{N}=141$ ) } \\
\hline geen opname & 55 & 39 & & & & \\
\hline wel opname(n) & 86 & 61 & 38 & $(39,3)$ & 22 & $1 / 198$ \\
\hline
\end{tabular}

In tabel 4.5. staan verschillende vormen van medicatie uit de Cara-geneesmiddelengroep vermeld. Hieruit blijkt onder andere, dat bij opname $79 \%$ van de patiënten afhankelijk was van de inhalatievorm van corticosteroïden, terwijl $64 \%$ van de patiënten orale corticosteroïden kreeg voorgeschreven. Aangaande het totale pakket aan medicatie bleek dat alle patiënten minimaal één van de medicijnen uit de Cara-geneesmiddelengroep kreeg voorgeschreven. Wat niet vermeld staat in de tabel is, dat $89 \%$ van de populatie was aangewezen op drie of meer van deze middelen.

Tabel 4.5. Medicatiegebruik bij opname $(N=! 45)$

\begin{tabular}{lccc}
\hline & $N$ & $\%$ & $M \quad$ (SD) \\
\hline theofylline-preparaten & 101 & 70 & \\
$\beta_{2}$-sympaticomimetica & 143 & 99 & \\
anticholinergica & 85 & 59 & \\
antihistaminica & 18 & 12 & \\
cromoglycaten & 34 & 23 & \\
mucolytica & 36 & 25 & $1129(560)$ \\
antibiotica & 13 & 9 & $2,9(4,0)$ \\
corticosteroiden (inhalatie) in mcg & 115 & 79 & \\
corticosteroiden (oraal) à 5 mg & 93 & 64 & \\
\hline
\end{tabular}

Uit analyses omtrent frequentie en omvang van aspecten van medische consumptie naar geslacht, blijkt dat hierop mannen niet van vrouwen verschilden. Ook de leeftijd blijkt niet samen te hangen met de frequentie van artsbezoeken en ziekenhuisopnamen. Een analyse van de verschil- 
lende medische consumptiekenmerken naar diagnose geeft geen significante verschillen te zien tussen de astma- en de COPD-populatie. Ook voor wat betreft het medicatiegebruik werd geen significant verschil tussen mannen en vrouwen aangetroffen, terwijl er zich tevens geen verschillen voordeden qua leeftijd. Inzake diagnose bleek er wel een onderscheid te bestaan: de astmapopulatie

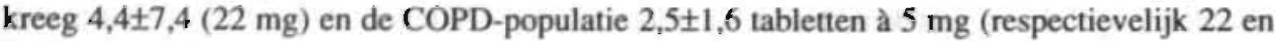
$14,5 \mathrm{mg}$ ) orale corticosteroïden per dag voorgeschreven ( $F=4.06 ; d f=91 ; p=.05$ ).

\subsection{Kwaliteit van leven-kenmerken}

In deze paragraaf worden de kenmerken van de onderzoekspopulatie met betrekking tot de 'kwaliteit van leven' weergegeven. Daarbij worden verschillende aspecten onderscheiden te weten, 1. functionele kenmerken, 2. psychologische kenmerken en 3. sociale kenmerken.

Tabel 4.6. toont de interne consistentie van de verschillende vragenlijsten die voor de beschrijving van deze aspecten zijn gebruikt. Hieruit is af te leiden dat de interme consistentie van de subschaal die optimisme meet onvoldoende is. Van alle andere vragenlijsten is deze goed. De optimismeschaal kan in dit onderzoek verder niet meer worden gebruikt, waarmee de variabele komt te vervallen. Van de SCL-90 en de NPV is de interme consistentie niet opnieuw bepaald, aangezien uit de handleidingen, waarin de psychometrische eigenschappen van deze lijsten worden besproken blijkt, dat deze goed zijn.

Tabel 4.6. Inteme consistenties volgens Cronbach's $\alpha$

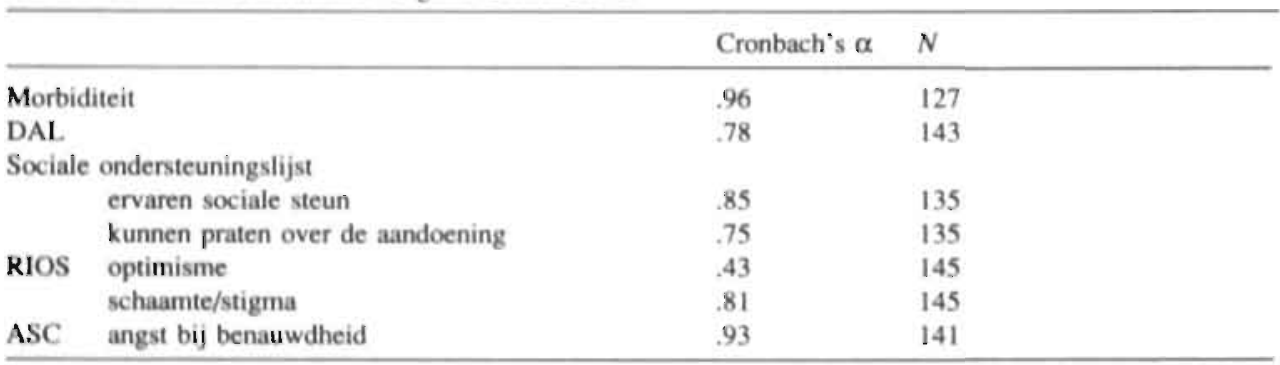

\subsubsection{Het functionele aspect van kwaliteit van leven}

Een belangrijk aspect van kwaliteit van leven bij Cara-patiënten, waaraan in longrevalidatie veel aandacht wordt besteed, zijin de functionele mogelijkheden. Ten behoeve van de beschrijving hiervan wordt in dit onderzoek onderscheid gemaakt tussen de ervaren beperkingen in dagelijkse acliviteiten en de ervaren kortademigheid.

In tabel 4.7. staan de aantallen en percentages weergegeven van de patiënten die een bevestigend antwoord gaven op de lijst die ervaren beperkingen in dagelijkse activiteiten meet. De gemiddelde score van de totale populatie is $6,09 \pm 1,91(N=143)$. De astmapopulatie had een gemiddelde

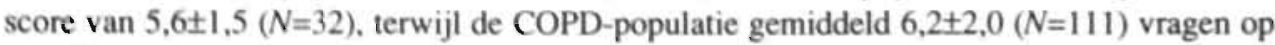
deze lijst bevestigend beantwoordde. Het verschil tussen de beide diagnosegroepen is niet significant $(r=-1.57 ; d f=141 ; p=.12)$.

De onderzoekspopulatie blijkt op deze vragenlijst ongunstiger te scoren dan een populatie eerstelijns Cara-patiènten, die een gemiddelde score had van 2,9 2,6 (Schrier et al., 1990) of een tweedelijns polikliniekpopulatie van Cara-patiënten met een gemiddelde score van $5,0 \pm 2,2$ op deze vragenlijst (Kaptein et al., 1987d). 
Voor wat betreft de variabele ervaren kortademigheid blijkt de gemiddelde score van de gehele onderzoekspopulatie $65,6 \pm 19,8(N=128)$ te zijn. De astmapopulatic $(N=26)$ had cen gemiddelde score van $68,0 \pm 22,2$, terwijl de COPD-populatic $(N=102)$ gemiddeld een score vertoonde van $65,0 \pm 19,2$. Dit verschil is niet significant $(t=70 ; d f=126 ; p=49)$.

Tabel 4.7. Percentages ja-antwoorden op de Dagelijkse Activiteiten Lijst van de totale onderzoekspopulatie en ondervendeeld naar diagnose

\begin{tabular}{llll}
\hline & totaal $(N=143)$ & astma $(N=32)$ & COPD (Nw111) \\
$N \%$ & $N \%$ & $N$ \%
\end{tabular}

Heeft u door uw gezondheid hulp nodig

bij het eten, aankleden, baden of naar

de w.c. gaan?

96

26

66

Brengt u vanwege uw gezondheid het grootste deel van de dag in bed of stoel doon?

Als u ergens heen gaat, moet iemand u dan helpen vanwege uw gezondheid?

Moet u door uw gezondheid het grootste deel van de dag binnenshuis blijven?

Heeft u vanwege uw gezondheid moeite met een klein stukje lopen, of met het traplopen naar één hoog? (zonder boodschappen)

Kunt u door uw gezondheid uw beroep niet meer uitoefenen of uw huishouden in het geheel niet meer doen?

Kunt u door uw gezondheid bepaalde onderdelen van beroep of huishouden niet meer uitvoeren, of moet u part-time werken vanwege uw gezondheid?

Heeft u vanwege uw gezondheid moeite met bukken, iets optillen of voorover buigen?

Wordt is door uw gezondheid op een of andere wijze belemmerd in iets wat u zou willen doen?

Heeft u vanwege uw gezondheid moeite met een flink stuk lopen of met traplopen van meerdere etages? (zonder boodschappen)

Bent u door uw gezondheid belemmerd in het uitvoeren van inspannende lichamelijke activiteit, zoals een stukje hardlopen of zware voorwerpen tillen? 
De psychologische kenmerken die worden beschreven betreffen persoonlijkheidskenmerken, psychische klachten, schaamte omtrent de aandoening en angst bij benauwdheid. Voor wat betreft de persoonlijkheidskenmerken en de psychische klachten wordt tevens een vergelijking gepresenteerd met andere populaties.

In tabel 4.8. worden de gemiddelden en standaarddeviaties vermeld van de scores op de subschalen van de vragenlijsten die persoonlijkheidskenmerken en psychische klachten meten. De verschillen tussen de scores van de astma- en COPD-populatie blijken niet significant, behoudens die van de scores op de subschaal 'slaapproblemen' van de SCL-90. Hierop scoorde de astmapopulatie ongunstiger dan de COPD-populatie. Deze score kan het gevolg zijn van nachtelijk dyspnoe bij de astmapopulatie.

De scores van de onderzoekspopulatie op de NPV en de SCL-90 werden vergeleken met scores van enkele normgroepen. Voor wat betreft de persoonlijkheidskenmerken werden de scores van de onderzoekspopulatie vergeleken met de normgroep 'normalen' en de normgroep 'somatisch zieken'. Inzake de psychische klachten wordt een vergelijking gepresenteerd met scores van de normgroepen 'gezonden' en 'somatisch zieken' (zie voetnoot, pag. 65).

Tabel 4.8. Scores op de subschalen van de NPV en de SCL-90 over de hele onderzoekspopulatie en onderverdeeld naar diagnose

\begin{tabular}{|c|c|c|c|c|c|}
\hline & \multicolumn{2}{|c|}{$\begin{array}{l}\text { totaal } \\
N=147\end{array}$} & $\begin{array}{l}\text { astma } \\
N=35\end{array}$ & \multicolumn{2}{|c|}{$\begin{array}{l}\text { COPD } \\
N=112\end{array}$} \\
\hline & $M$ & $(S D)$ & $M \quad(S D)$ & $M$ & $(S D)$ \\
\hline \multicolumn{6}{|c|}{ NVP' (persoonlijkheidskenmerken) } \\
\hline inadequatic & 16,7 & $(8,8)$ & $17,0(8,6)$ & 16,5 & $(8,6)$ \\
\hline sociale inadequatic & 11,7 & $(7,6)$ & $10.4(6,8)$ & 12.1 & $(7,8)$ \\
\hline rigidditeit & 29.3 & $(7,8)$ & $30,2(7,4)$ & 29,0 & $(7,9)$ \\
\hline verongelijktheid & 18,5 & $(6,8)$ & $17,3(7,6)$ & 18.9 & $(6,5)$ \\
\hline zelfgenoegzaamheid & 13.7 & $(5,5)$ & $14,8(5,4)$ & 13,4 & $(5,5)$ \\
\hline dominantic & 13,4 & $(5,6)$ & $12,5(5,7)$ & 13.7 & $(5,5)$ \\
\hline zelfwaardering & 23,9 & $(6,8)$ & $25,7(6,4)$ & 23,3 & $(6,9)$ \\
\hline \multicolumn{6}{|l|}{ SCL (psychische klachsen) } \\
\hline angst & 19,0 & $(7,1)$ & $19.7(7.7)$ & 18,8 & $(6,9)$ \\
\hline agorafobie & 10,8 & $(4,9)$ & $9.5(3.5)$ & 11,3 & $(5,3)$ \\
\hline depressie & 30,0 & $(10,8)$ & $29.9(9.3)$ & 30,0 & $(11,2)$ \\
\hline somatiseren & 25,8 & $(8,3)$ & $27,2(7,2)$ & 25,4 & $(8,6)$ \\
\hline insufficiëntie denken en handelen & 19.5 & $(6,7)$ & $20,0(6,0)$ & 19.3 & $(6,9)$ \\
\hline $\begin{array}{l}\text { wantrouwen en interpersoonlijke } \\
\text { sensitiviteit }\end{array}$ & 28,7 & $(9,7)$ & $28,6(10,0)$ & 28.7 & $(9,7)$ \\
\hline hostiliteit & 8.2 & $(2,4)$ & $8.7(2,8)$ & 8,1 & $(2,3)$ \\
\hline slaapproblemen & 8,3 & $(3,8)$ & $9,9(3.9)$ & 7.8 & $(3,6)^{\circ}$ \\
\hline psychoneuroticisme & 165,0 & $0(47,9)$ & $166,6(41,9)$ & 164.4 & $4(49,8)$ \\
\hline
\end{tabular}

$p<05$ 
Tabel 4.9. Vergelijking van de scores op de NPY en de SCL-90 tussen de onderzoekspopulatie en enkele nomgroepen

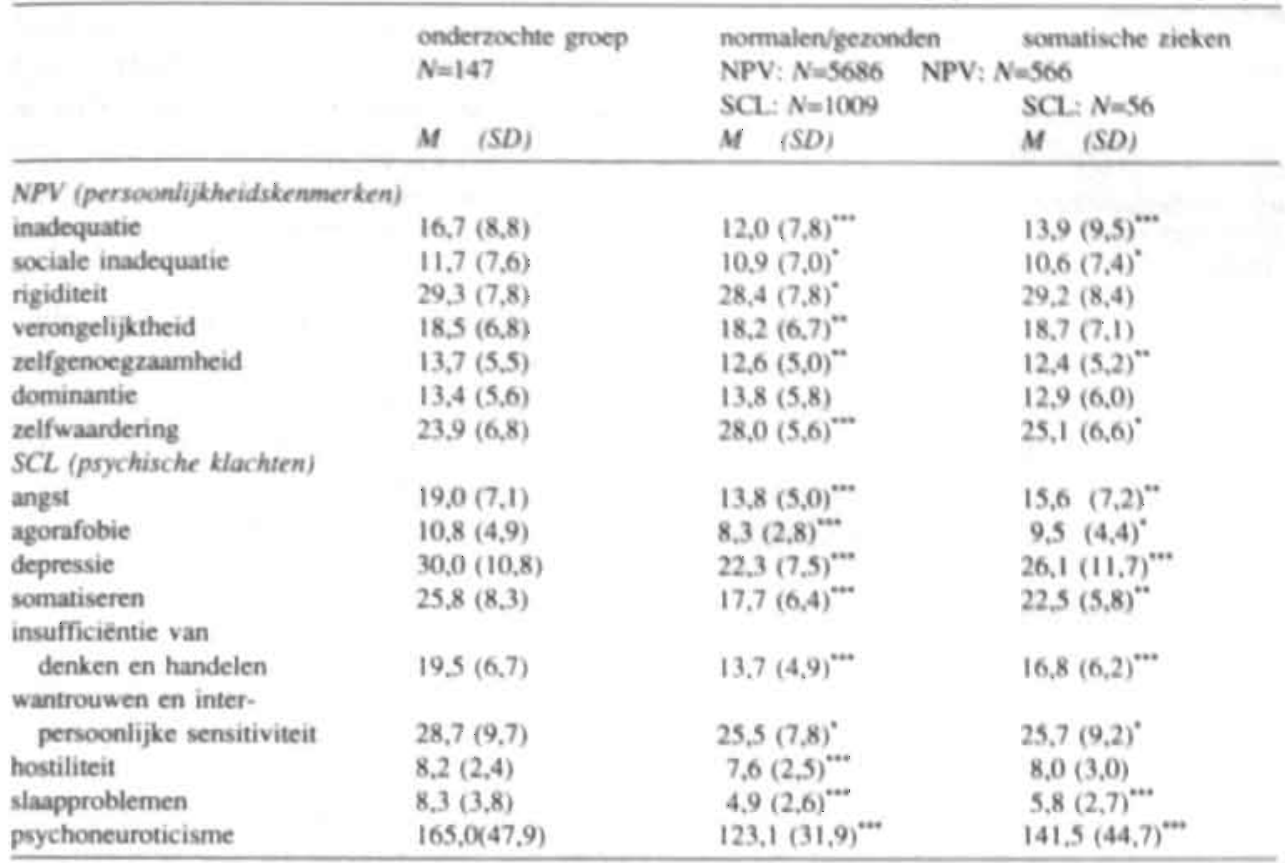

"p<.05: " $p<.01 ;{ }^{\cdots} p<.001$ in vergelijking met de onderzocksgroep bij tweezijdige toetsing

Tabel 4.9. geeft zowel de scores weer van de onderzoekspopulatie als van de genoemde nomgroepen ${ }^{1}$. Bij toetsing van verschillen is gebleken, dat de onderzoekspopulatie in vergelijking met de normgroep 'gezonden' en de normgroep 'normalen' op alle variabelen, behalve op de variabele 'dominantie', significant ongunstiger scoorde. In vergelijking met de normgroepen 'somatisch zieken' bleek de onderzoekspopulatie eveneens ongunstiger te scoren, behalve op de variabelen 'rigiditeit', 'verongelijktheid', 'dominantie " en 'hostiliteit'. De gemiddelde scores op de ziektespecifieke psychologische kenmerken 'schaamte' en 'angst bij benauwdheid', staan vermeld in tabel 4.10. Hieruit blijkt dat de COPD-populatie meer schaamte ondervond dan de astmapopulatie ( $l=-2.04 ; d f=144 ; p=.04$ ). Op de schaal die angsi bij benauwdheid meet werden geen significante verschillen tussen de astma- en de COPD-populatie aangetroffen $(t=-35 ; d f=140$; $p=.73)$.

\footnotetext{
'De handleiding van de SCL-90 geeft aan dat het bij đeze groep gaat om somatische patiènten bij revalidatieafdelingen en een afdeling cardiologie. De NPV-handleiding geef de volgende omschrijving bij de normgroep 'somatisch zieken': De normgrọep somatische patiënten bestaat uit opgenomen patiënten die cen myocardinfarct hebben gehad, poliklinische reumapatiènten, patiënten die hoofdzakelijk voor ongevallen of stoomissen aan de ademhalingswegent gerevalideerd werden en patiënten met chronische pijnklachten. De groep is qua leeftijd en schoolopleiding zeer heterogeen en bevat ongeveer evenveel mannen als vrouwen. De verschillen tussen de subgroepen met betrekking tot de NPV-schalen zijn dermate gering dat samenvoeging verantwoord is. De NPV is meestal individueel als onderdeel van klinisch diagnostisch onderzoek afgenomen' (Luteijn et al., 1985; Arrindell et al., 1986).
} 
Tabei 4.10. Gemiddelde scores op de subschalen schaarnte en angst bij benauwdheid voor de totale onderzoekspopulatie en naar diagnose

\begin{tabular}{llllll}
\hline & \multicolumn{1}{l}{ totaal } & \multicolumn{2}{c}{ astma } & \multicolumn{2}{c}{ COPD } \\
& $M \quad$ (SD) $N \quad \min / \max$ & $M$ & (SD) $N$ & $M$ & (SD) $N$ \\
\hline schaamte $(N=146)$ & $16,5(7,2) 146$ & $7 / 35$ & $14.3(6,8) 34$ & $17,1^{*}(7,1) 112$ \\
angst bij benauwdheid $(N=142)$ & $25,6(8,6) 142.10 / 47$ & $25,1(10,1) 35$ & $25,7(8,1) 107$ \\
\hline
\end{tabular}

p $<.05$

Op de kenmerken 'inadequatie', 'zelfwaardering' en 'schaamte' is een vergelijking mogelijk met scores op dezelfde variabelen van recent onderzochte Cara-patiënten uit de eerste en de tweede lijn (Colette, 1993). Qua inadequatie en zelfwaardering bleek dat de NAD-populatie ongunstiger scoorde, terwijl dat voor de variabele schaamte niet het geval was. Wanneer de scores worden vergeleken met een tweedelijns-populatie (Kaptein, 1982) blijkt, dat de onderzoeksgroep van het NAD ongunstiger scoorde op schaamte, echter niet op angst bij benauwdheid.

\subsubsection{Sociale aspecten van kwaliteit van leven}

In tabel 4.13, worden de scores van de onderzoekspopulatie op de twee subschalen van de sociale ondersteuningslijst weergegeven. Het betreft de schaal die de ervaren sociale steun meet en de schaal die meet in hoeverre de patiënt zich in de gelegenheid voelt over de ervaringen met betrekking tot het leven met de aandoening met gezinsleden en vrienden te praten (afgekort: kunnen praten over de aandoening). De scores van de astmapopulatie en die van de populatie COPD-patiënten op deze twee subschalen, werden met elkaar vergeleken. De scores van de twee diagnosegroepen bleken op beide schalen geen significant verschil te vertonen (ervaren steun: $t=.39 ; d f=133 ; p=.69 ;$ kunnen praten over de aandoening: $t=.24 ; d f=129 ; p=.82$ ).

Tabel 4.13. Gemiddelde scores op de subschalen ervaren sociale steun en kunnen praten over de aandoening

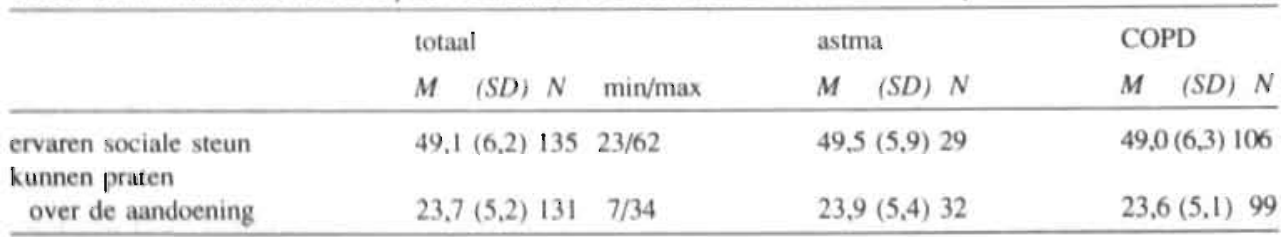

\subsection{Samenvatting en conclusies}

In dit hoofdstuk werden de kenmerken van de onderzoeksgroep, betrokken uit het bestand van patiënten die naar het NAD worden verwezen, beschreven. Dit geschiedde aan de hand van diagnose- en longfunctiekennerken, aspecten van medische consumptie, te weten de huisartsen specialistbezoeken, ziekenhuisopnamen, ziekenhuisdagen en medicatiegebruik, alsmede kenmerken die tezamen kunnen worden begrepen onder de term 'kwaliteit van leven'.

Uit de beschrijuing blijkt dat de onderzoekspopulatie er in verschillende opzichten emstig aan toe is. Het merendeel van de populatie bestaat uit COPD-patiënten, dat wil zeggen, patiënten met een beperkte mate van reversibiliteit van de luchtwegobstructie. Overigens is deze reversibiliteit voor wat betreft de COPD-populatie relatief groot, hetgeen erop kan wijzen dat bij deze COPDpopulatie tevens een min of meer verborgen astmacomponent aanwezig kan zijn. Verder blijkt dat de longfunctie fors gestoord is. 
Ten aanzien van het rookgedrag valt op dat de COPD-populatie meer dan twee maal zoveel heeft gerookt dan de astmapopulatie.

Qua medische consumptie blijkt in de eerste plaats, dat een groot deel van de populatie die in het NAD werd opgenomen afhankelijk is van een relatief hoge doseringen orale corticosteroiden, een vorm van medicatie die bij regelmatig gebruik kan leiden tot emstige bijverschijnselen (onder andere stemmingswisselingen, gewichtstoename, spierzwakte, verhoogde bloeddruk, suikerziekte, dunne huid, bloedingen en gestoorde wondgenezing). Deze hoge dosis betrof in het bijzonder de astmapopulatie. Een nog groter deel van de patiënten kreeg inhalaticcorticosteroïden voorgeschreven. Een aanzienlijk percentage patiënten was aangewezen op drie of meer soorten medicijnen uit de Cara-geneesmiddelengroep. De hoge medische consumptie kwam eveneens tot uitdrukking in het aantal huisarts-en specialistbezoeken en bleek uit de frequentie van de ziekenhuisopnamen en het aantal ziekenhuisdagen dat de patiënten gemiddeld vanwege Cara in een ziekenhuis moesten doorbrengen.

De kwaliteit van leven van de patiënten, die in aanmerking kwamen voor opname in het NAD, bleek gering te zijn. Qua functionele mogelijkheden ondervond de populatie forse beperkingen in dagelijkse activiteiten. Deze beperkingen bleken aanzienlijker dan die van populaties Carapatiēnten uit de eerste en de tweede lijn. In psychologisch opzicht was sprake van een hoge mate van angst en depressie. In vergelijking met andere populaties, waaronder somatisch zieken in het algemeen, scoorde de onderzoeksgroep ongunstiger. Op de ziekte-specifieke psychologische kenmerken bleek de onderzoeksgroep niet overtuigend ongunstiger te scoren dan populaties eerste- en tweedelijns patiènten. Aangaande de sociale kenmerken konden helaas geen vergelijkingen met andere populaties worden gemaakt. 


\subsection{Inleiding}

In dit hoofdstuk wordt een antwoord gegeven op de tweede en de derde onderzoeksvraag. De tweede vraag luidt: Wat is het beloop van scores op de kenmerken aangaande medische consumptie en kwaliteit van leven, gemeten over de meetmomenten opname, ontslag, 6 maanden en 12 maanden na ontslag. De derde onderzoeksvraag luidt: Hoeveel patienten zijn, gemeten 12 maanden na ontslag, in vergelijking met het moment van opname verbeterd, verslechterd, of onveranderd met betrekking tot de aspecten van kwaliteit van leven en medische consumptie? ${ }^{2}$

Allereerst zal in paragraaf 5.2. een vergelijking worden gepresenteerd van de scores op de onafhankelijke variabelen, gemeten bij opname, van patiěnten die wel en die niet respondeerden op het moment van 12 maanden na ontslag. In paragraaf 5.3. worden de beide vraagstellingen uitgewerkt inzake de medische consumptie en in paragraaf 5.4. aangaande de aspecten van kwaliteit van leven.

\subsection{Vergelijking van scores van respondenten en non-respondenten}

Op het eerste meetmoment bestond de onderzoeksgroep uit 148 patiénten. Reeds bij dit meetmoment bleek het niet mogelijk om van alle patiènten alle gegevens te verkrijgen. Vervolgens bleek de non-respons per meetmoment toe te nemen. Wanneer de patiènten die wel en die niet responderen qua scores van elkaar verschillen dient daarmee bij de interpretatie van de resultaten rekening te worden gehouden. Om na te gaan of dit het geval is werd bekeken of de opnamescores op de belangrijkste onderzoeksvariabelen van de groep patiënten die 12 maanden na ontslag wel respondeerde, verschillen van de groep die op dat moment niet respondeerde. Dit is gebeurd voor wat betreft de onderzoeksvariabelen en enkele variabelen die kenmerken van de populatie uitdrukken. Het resultaat van de analyses wordt gepresenteerd in tabel 5.1 .. In het cerste deel van de tabel staan de variabelen vermeld waarvan de scores normaal zijn verdeeld, terwijl in het tweede en derde deel van de tabel variabelen staan vermeld die respectieve-lijk niet normaal zijn verdeel en die uit dichotome scores bestaan.

\footnotetext{
'Delen van dit hoofdstuk zijn eerder gepubliceerd (Van der Schoot, T.A.W., De Weerdt, I., Kaptein, A.A., Dekker, F.W., Deenen, Th. A.M. \& Speelberg. B. Nederlands Tijdschrift voor Geneeskunde, 1993, 137, 197-201).

${ }^{2}$ Het resultaat van opname in het NAD met betrekking tot de peak flow respiratory rate (PEFR) en de longfunctie werd beschreven door Speelberg et al. (1992; 1994).
} 
Tabel 5.1. Gemiddelde scores en aantallen bij opname op de onderzoeksvariabelen en variabelen die kenmerken van de populatie beschrijven bij patiënten die wel en niet respondeerden tijdens het meetmoment van 12 maanden na ontslag

\begin{tabular}{|c|c|c|c|c|c|c|c|}
\hline & \multicolumn{3}{|c|}{ respondenten } & \multicolumn{2}{|c|}{ nonrespondenten } & \multirow{2}{*}{$\begin{array}{l}\text { t-test } \\
d f\end{array}$} & \multirow{2}{*}{$t$} \\
\hline & M & $(S D)$ & $N$ & M & (SD) $N$ & & \\
\hline leeftijd & 51,1 & $(12,5) 9$ & 95 & 52,8 & $(15,4) 53$ & 146 & -.75 \\
\hline VC voor medicatie (\% norm) & 89,3 & $(22,3) \mathrm{IC}$ & 103 & 85,8 & $(28,0) 28$ & 36.79 & $.6 \mathrm{I}$ \\
\hline FEV, voor medicatie (\% norm) & 61.6 & $(25.7) 11$ & 112 & 57.5 & (19.9) 25 & 135 & .76 \\
\hline \multicolumn{8}{|l|}{ ervaren beperkingen in } \\
\hline dagelijkse activiteiten & 6,0 & (1.9) 95 & 95 & 6,3 & $(1.9) 48$ & 141 & -.89 \\
\hline kortademigheid & $66,2($ & $(10,9) 7$ & 74 & 64,8 & $(21,1) 54$ & 126 & .39 \\
\hline NPV inadequatie & 16.5 & $(8,9) 10$ & 100 & 17,0 & $(8,8) 47$ & 145 & -.31 \\
\hline NPV sociale inadequatie & 12,4 & $(7,4) 9$ & 99 & 10,3 & $(7.8) 48$ & 145 & 1.52 \\
\hline NPV zelfwaardering & 24,3 & $(7,0) 10$ & 101 & 23.0 & $(6,4) 46$ & 145 & 1.13 \\
\hline $\mathrm{SCL}$ angst & 19,3 & $(6,8) 10$ & 100 & 18,4 & $(7,7) 47$ & 145 & .68 \\
\hline SCL agorafobie & 11,1 & $(5,3) 10$ & 100 & 10,3 & $(4,2) 47$ & 145 & .98 \\
\hline $\mathrm{SCL}$ depressie & 29,6 & $(9,8) 10$ & 100 & 30,9 & $(12,7) 47$ & 145 & -.64 \\
\hline ervaren sociale steun & 49,2 & $(6,3) 8$ & 87 & 48.9 & $(6,3) 48$ & 133 & .27 \\
\hline \multirow[t]{3}{*}{ kunnen praten over aandoening } & 24,7 & $(4,3) \quad 8$ & 87 & 21,8 & $(6,1) 44$ & 65.42 & $2.82^{\circ}$ \\
\hline & \multicolumn{3}{|c|}{ respondenten } & \multicolumn{4}{|c|}{ non-respondenten } \\
\hline & M & (SD) $N$ & $N$ & M & (SD) $N$ & Mannth & hitney \\
\hline \multicolumn{8}{|l|}{ MEDISCHE CONSUMPTIE } \\
\hline huisartsconsulten & $7,0($ & $(11,9) 12$ & 23 & 7,3 & $(6,6) 13$ & -.97 & \\
\hline specialistconsulten & 7,1 & $(4,3)$ il & 16 & 7,2 & $(5,6) \quad 19$ & -65 & \\
\hline ziekenhuisopnamen & 1.8 & $(1,5) 75$ & 75 & 1,7 & $(0.5) \quad 6$ & -.86 & \\
\hline ziekenhuisdagen & 33,8 & $(40,0) 9$ & 93 & 18,3 & (7.5) 7 & -.10 & \\
\hline orale corticosteroìden & 2,4 & $(2,2) 71$ & 71 & 3,3 & $(6,1) 29$ & -.47 & \\
\hline \multirow[t]{3}{*}{ pakjaren } & 8.2 & $(12,7) 9$ & 93 & 10,0 & $(16,1) \quad 7$ & -.33 & \\
\hline & \multicolumn{3}{|c|}{ respondenten } & \multicolumn{4}{|c|}{ non-respondenten (op de DAL) } \\
\hline & $N$ & $\%$ & & $N$ & $\%$ & $x^{2}$ & \\
\hline $\operatorname{man}$ & 47 & 49 & & 19 & 40 & 1.26 & \\
\hline vrouw & 48 & 51 & & 29 & 60 & & \\
\hline astma & 17 & 18 & & 15 & 31 & 3.24 & \\
\hline COPD & 78 & 82 & & 33 & 69 & & \\
\hline samenwonend & 64 & 69 & & 29 & 62 & .71 & \\
\hline alleenwonend & 29 & 31 & & 18 & 38 & & \\
\hline lager opgeleid & 44. & 61 & & 25 & 61 & .00 & \\
\hline hoger opgeleid & 28. & 39 & & 16 & 39 & & \\
\hline
\end{tabular}

${ }^{*} p<.05 ;{ }^{*} p<.01$

Uit bovenstaande blijki dat de groep van patiènten die 12 maanden na ontslag niet respondeerde, bij opname een ongunstiger score vertoonde op de variabele die 'kunnen praten over de aandoening' meet dan de groep van patiènten die wel respondeerde. Non-respondenten bleken, met andere woorden, minder goed in staat over de ervaringen met de aandoening te praten. 


\subsection{Medische consumptie}

In tabel 5.2. worden het gemiddelde aantal huisarts- en specialistbezoeken, ziekenhuisopnamen en ziekenhuisdagen gepresenteerd voor wat betreft de perioden van é́n jaar vóór opname en eén jaar na ontslag. Uit de cijfers blijkt, dat het aantal huisarts- en specialistconsulten, alsmede het aantal ziekenhuisopnamen en ziekenhuisdagen in het jaar na ontslag. ten opzichte van het jaar vóór opname, is afgenomen.

Tabel 5.2. Artsconsulten en ziekenhuisopnamen voor en na verblijf in het NAD

\begin{tabular}{|c|c|c|c|c|c|c|c|c|c|}
\hline & \multicolumn{4}{|c|}{ gedurende den jaar voor opname } & \multicolumn{5}{|c|}{ gedurende eén jaar na ontslag } \\
\hline & mediaan & $M$ & $(S D)$ & $N$ & mediaan & $M$ & $(S D)$ & $N$ & Mirn Whitaxy \\
\hline huisarts & 4 & 6,7 & (11.3) & 143 & 2 & 4,5 & $(10,5)$ & 130 & $-2.71^{* *}$ \\
\hline specialist & 6 & 6.9 & $(4,5)$ & 137 & 5 & 5.7 & $(4,2)$ & 128 & $-2.82^{* *}$ \\
\hline ziekenhuisopnamen & 1 & 1,2 & $(1.5)$ & 122 & 0 & 0,8 & $(1,3)$ & 130 & $.2 .73^{* *}$ \\
\hline ziekenhuisdagen & 9 & 23,2 & $(35,8)$ & 141 & 0 & 12,9 & $(26,1)$ & 129 & $-3.63^{* \ldots}$ \\
\hline
\end{tabular}

" pe.01; ${ }^{\cdots}$ p<.001

In tabel 5.3. staan de aantallen en percentages vermeld van patiènten die in vergelijking met het jaar vóor opname in het NAD, gedurende het jaar ná ontslag uit het NAD, respectievelijk minder, evenveel of méér consulten van de huisarts of specialist behoefden. Deze gegevens worden eveneens verstrekt voor de ziekenhuisopnamen en de ziekenhuisdagen die er in verband met Cara-klachten waren. Hierbij werd uitgegaan van de groepen patiènten die vóor opname of na ontslag minimaal respectievelijk één huisarts-, specialistcontact, ziekenhuisopname of ziekenhuisdag achter de rug had. Aangezien er bij de ziekenhuisopnamen en de ziekenhuisdagen van wordt uitgegaan dat een vermindering van het aantal een verbetering uitdrukt, kan worden gesteld dat qua ziekenhuisopnamen $52 \%$ van de onderzoeksgroep is verbeterd en $48 \%$ niei is verbeterd. Voor wat betreft het aantal ziekenhuisdagen tijdens het jaar ná ontslag uit het NAD blijkt $50 \%$ te zijn verbeterd en $50 \%$ niet te zijn verbeterd.

Tabel 5.3. Aantallen en percentages patiènten dat gedurende de periode van één jaar na ontslag, in vergelijking met de periode van één jaar vór opname, respectievelijk minder, even veel, of meer artsbezoeken of ziekenhuisopnamen hadden in verband met Cara.

\begin{tabular}{|c|c|c|c|c|}
\hline & minder & onveranderd & \multicolumn{2}{|c|}{ meer } \\
\hline & $N \%$ & $N \quad \%$ & $N$ & $\%$ \\
\hline huisarts $(N=123)$ & $47 \quad 38$ & $54 \quad 41$ & 26 & $2 I$ \\
\hline specialist $(N=\| 16)$ & $46 \cdot 40$ & 4135 & 29 & 25 \\
\hline ziekenhuisopnamen $(N=75)$. & 3952 & $14 \quad 19$ & 22 & 29 \\
\hline ziekenhuisdagen $(N=93)$ & 4650 & 2527 & 22 & 23 \\
\hline
\end{tabular}

In tabel 5.4. staat het gemiddelde corticosteroïdgebruik vermeld. Hieruit blijkt dat de onderzoekspopulatie bij opname gemiddeld 1,8 $\pm 3,4$ tabletten à $5 \mathrm{mg}$ yan dit middei kreeg voorgeschreven. Bij ontslag en 6 maanden na ontslag werden respectievelijk $1,1 \pm 1,3$ en 1,0 $\pm 1,3$ tabletten à $5 \mathrm{mg}$ voorgeschreven, terwijl dit aantal op het moment van 12 maanden na ontslag $1,2 \pm 1,5$ bedroeg. Uit deze cijfers blijkt dat de gemiddelde hoeveelheid orale corticosteroïden russen opname en ontslag drastisch is gedaald en dat deze gunstige verandering zeker tot 12 maanden na ontslag stand hield. 
Tabel 5.4. Gemiddeld corticosteroìdgebruik op de meetmomenten

\begin{tabular}{lllll}
\hline & bij oprame & bij ontslag & $\begin{array}{l}6 \text { maanden } \\
\text { na ontslag }\end{array}$ & $\begin{array}{l}12 \text { maanden } \\
\text { na ontslag }\end{array}$ \\
VORM & $M \quad(S D) N$ & $M \quad(S D) N$ & $M \quad(S D) N$ & $M \quad(S D) N$ \\
\hline oraal a $5 \mathrm{mg}$ & $1,8(3,4) 145$ & $1,1(1,3) 117$ & $1,0(1,3) 114$ & $1,2(1,5) 98^{* *}$ \\
inhalatie in mcg & $895(678) 145$ & $955(820) 119$ & $976(804) 115$ & $999(705) 98^{*}$ \\
\hline
\end{tabular}

" $p<.05_{i} \cdots p<.001$, in vergelijking met de waarde bij opname.

Wanneer de patiënten die zowel bij opname als 12 maanden na ontslag deze medicatie niet kregen voorgeschreven buiten beschouwing worden gelaten, bedroeg het aantal bij opname $2,7 \pm 3,8(N=101)$ en 12 maanden na ontslag $1,6 \pm 1,5,(N=72)$ tabletten à $5 \mathrm{mg}$ (Mann-Whitney $=3.74 ; p<.001)$, hetgeen eveneens duidt op een aanzienlijke verbetering. Hoewel de astmapopulatie zowell bij opname als bij ontslag een iets hogere dosering van deze medicatie $\mathrm{kreeg}$, bleek dit verschil niet significant. Opvallend is dat 12 maanden na ontslag het gemiddeld gebruik van inhalatie corticosteroïden ten opzichte van het moment van opname bleek te zijn toegenomen. Kennelijk ging een af́name van de dosering orale corticosteroïden gepaard met een toename van de dosering inhalatie corticosteroïden. Gezien de bijverschijnselen die met de orale vorm gepaard gaan is dit een gunstig resultaat.

Wasneer de omvang van het inhalatiesteroïdgebruik alleen wordt bekeken voor het cohor dat dil medicijn bij opname of 12 maanden na ontslag kreeg voorgeschreven werd een gemiddeld gebruik van respectievelijk $1038 \pm 619 \mathrm{mcg}$ en $1100 \pm 659 \mathrm{mcg}$ aangetroffen (Mann-Whitney $=-2.22 ; p<.05$ ), hetgeen een geringe verhoging is.

In tabel 5.5. staan de aantallen en percentages van patiënten weergegeven die, in vergelijking met het moment van opname, 12 maanden na ontslag minder, even veel of meer van dit medicijn gebruikten. Zoals eerder opgemerkt betreffen de getallen het cohort dat of bij opname of 12 maanden na ontslag diı medicijn kreeg voorgeschreven. Aangezien een lagere dosering van de orale vorm wordt beschouwd als een verbetering, kan op basis van de percentages worden gesteld dat $35 \%$ van helt cohort op het moment van 12 maanden na ontslag is verbeterd ten opzichte van het moment van opname, terwijl $65 \%$ niet is verbeterd. Voor de inhalatievorm geldt dat $33 \%$ van het cohort minder, $47 \%$ evenveel en $21 \%$ van de patiënten meer kreeg voorgeschreven.

Tabel 5.5. Aantallen en percentages patiēnten đat 12 maanden na ontslag, in vergelijking met het moment van opname respectievelijk minder, even veel en meer orale, en inhalatie corticosteroïden gebruikte in verband met Cara

\begin{tabular}{|c|c|c|c|c|c|c|}
\hline \multirow[b]{2}{*}{ VORM } & \multicolumn{2}{|c|}{ minder } & \multicolumn{2}{|c|}{ onveranderd } & \multicolumn{2}{|c|}{ meer } \\
\hline & & $\%$ & & $\%$ & $N$ & $\%$ \\
\hline oraal a $5 \mathrm{mg}(\mathrm{N}=71)$ & 25 & 35. & 39 & 55 & 7 & 10 \\
\hline inhalatie $(N=88)$ & 29 & 33 & 41 & 47 & 18 & 20 \\
\hline
\end{tabular}

\subsection{Kwaliteit van leven}

In deze paragraaf wordt het beloop van de scores op de variabelen betreffende de functionele, psychologische en sociale aspecten van kwaliteit van leven geschetst. Inzake de functionele kenmerken worden de scores op de variabelen 'ervaren beperkingen in dagelijkse activiteiten' en 'kortademigheid' gepresenteerd. Met betrekking tot de laatstgenoemde variable zij eraan 
herinnerd dat een hoge score gunstig is. Qua psychologische kenmerken wordt het beloop van de scores op de NPV-schalen 'inadequatie', 'sociale inadequatie' en 'zelfwaardering', de SCL-90schalen 'angst', 'agorafobie' en 'depressie', de RIOS-schaal 'schaamte' en de ASC-schaal 'angst bij benauwdheid' weergegeven. Betreffende het sociale aspect worden de scores op de schalen 'ervaren sociale steun' en 'kunnen praten over de aandoening' over de verschillende meetmomenten in kaart gebracht. In tabel 5.6. staan de gemiddelde scores op de betreffende variabelen per meetmoment weergegeven.

Tabel 5.6. Gemiddelde scores op functionele, psychologische en sociale aspecten van kwaliteir van leven bij patiěnten. voor en na verblijf in het NAD

\begin{tabular}{|c|c|c|c|c|}
\hline \multirow[t]{2}{*}{$\begin{array}{l}\text { ASPECTEN VAN } \\
\text { KWALITEIT VAN LEVEN }\end{array}$} & $\begin{array}{l}\text { bij } \\
\text { opname }\end{array}$ & $\begin{array}{l}\text { bij } \\
\text { ontslag }\end{array}$ & $\begin{array}{l}6 \text { maanden } \\
\text { na ontslag }\end{array}$ & $\begin{array}{l}12 \text { maanden } \\
\text { na ontslag }\end{array}$ \\
\hline & $M(S D) N$ & $M$ (SD) $N$ & $M(S D) N$ & $M(S D) N$ \\
\hline \multicolumn{5}{|l|}{$\begin{array}{l}\text { FUNCTIONEEL } \\
\text { ervaren beperkingen }\end{array}$} \\
\hline dagelijkse activiteiten & $6.1(1.9) 143$ & $4,8(2,3) 118$ & $5,4(2,6) 115$ & $5,5(2,4) 95$ \\
\hline kortademigheid & $65,6(19,8) 128$ & $88,4(24,6) 94$ & $75,0(24,1) 94$ & $75,4(25,2) 82$ \\
\hline \multicolumn{5}{|l|}{ PSYCHOLOGISCH } \\
\hline schaamte & $16,5(7,1) 146$ & $15,1(6,9) 133$ & $15,3(4,7) 116$ & $15,4(4,6) 100$ \\
\hline angst bij benauwdheid & $25,6(8,6) 142$ & $23,8(8,6) 132$ & $24,6(8,7) 112$ & $25,5(9,4) 97$ \\
\hline \multicolumn{5}{|l|}{ NPV } \\
\hline inadequatie & $16.6(8,8) 147$ & $14,8(8,8) 134$ & $15.7(10,1) 116$ & $|4,9(9,9)| 00$ \\
\hline sociale inadequatie & $11.7(7.6) 147$ & $10,9(7,8) 134$ & $10,9(8,1) 116$ & $10,8(8,0) 100$ \\
\hline zelfwaardering & $23.9(6.8) 147$ & $24,9(6,8) \mid 34$ & $23,6(6,5) 116$ & $23,9(7,1) 100$ \\
\hline \multicolumn{5}{|l|}{ SCL-90 } \\
\hline angst & $19,0(7,1) 147$ & $17,2(7,9) 134$ & $17,8(7,2) 115$ & $17,7(7,5) 100$ \\
\hline agorafobie & $10,8(7,1) 147$ & $9.4(3.9) 134$ & $9.9(4,1) \quad 115$ & $10,2(5,2) 100$ \\
\hline depressie & $30.0(10.8) 147$ & $26.1(9.8) 134$ & $26.9(10.4) 115$ & $26.9(11,5) 100$ \\
\hline \multicolumn{5}{|l|}{ SOCIAAL } \\
\hline ervaren sociale ondersteuning & $49,1(6.2) 135$ & $50.4(7,1) 119$ & $49,8(7,0) \quad 112$ & $50,2(6,4) 92$ \\
\hline kunnen praten over de aandoening & $23,7(5.2) 131$ & $25.4(4.8) 110$ & $24.7(5,3) 106$ & $25,7(4,8) 91$ \\
\hline
\end{tabular}

Uit tabel 5.6. blijkt, dat de onderzoeksgroep bij ontslag in functioneel, psychologisch en sociaal opzicht een gunstiger gemiddelde score had dan bij opname. De gemiddelde scores op de functionele kenmerken blijken vervolgens op de momenten 6 maanden en 12 maanden na ontslag iets ongunstiger dan bij ontslag, echter, nog steeds gunstiger dan bij opname. Hetzelfde beloop wordt aangetroffen bij de overige kenmerken: de gemiddelde scores bij ontslag zijn gunstiger dan bij opname, terwijl de gemiddelde scores op de momenten 6 maanden na ontslag en 12 maanden na ontslag iets ongunstiger zijn dan die bij ontslag, echter gunstiger dan bij opname. De scores op het moment van 12 maanden na ontslag blijken tamelijk stabiel ten opzichte van het moment van 6 maanden na ontslag.

Vervolgens worden vergelijkingen van gemiddelde scores op de betreffende variabelen tussen opname en ontslag (tabel 5.7.), opname en 6 maanden na ontslag (tabel 5.8.) en opname en 12 maanden na ontslag (tabel 5.9.) gepresenteerd. Ten slotte worden aantallen en percentages gegeven van patiënten die 12 maanden na ontslag, in vergelijking met het moment van opname een verbeterde, onveranderde of verslechterde score hadden (tabel 5.10.).

Uit tabel 5.7. blijkt dat alle kenmerken (behalve de zelfwaardering) bij ontslag significant gunstiger zijn dan bij opname. 
Tabel 5.7. Gepaarde t-tests bij scores op aspecten van kwaliteit van leven bij opname en bij ontslag

\begin{tabular}{|c|c|c|c|c|c|c|}
\hline & \multicolumn{2}{|c|}{ opname } & \multicolumn{3}{|c|}{ ontslag } & \multirow[b]{2}{*}{ P } \\
\hline & $M^{\prime}$ & $(S D)$ & M & (SD) & $t$ & \\
\hline \multicolumn{7}{|l|}{ ervaren beperkingen } \\
\hline dagelijkse activiteiten $(N=117)$ & 6.1 & $(1,9)$ & 4,8 & $(2,3)$ & 6.04 & .000 \\
\hline kortademigheid $(N=84)$ & 66,4 & $(20,0)$ & 88.7( & $(24,8)$ & 7.77 & .000 \\
\hline schaamte $(N=132)$ & 16.5 & $(7,3)$ & 15,1 & $(4,7)$ & 2.91 & .004 \\
\hline angst bij benauwdheid $(N=130)$ & 25,8 & $(8,8)$ & 23,8 & $(8,9)$ & 3.62 & .000 \\
\hline NPV inadequatie $(N=134)$ & 16,7 & $(8,8)$ & 14,8 & $(8,8)$ & 3.07 & .003 \\
\hline NPV sociale inadequatie $(N=134)$ & 12,0 & (7.7) & 10,9 & $(7,8)$ & 2.46 & .015 \\
\hline NPV zelfwaardering $(N=134)$ & 24,0 & $(6,4)$ & 24,9 & $(6,8)$ & -1.92 & .058 \\
\hline $\mathrm{SCL}$ angst $(N=134)$ & 19.0 & $(7,2)$ & 17,2 & $(7,9)$ & 3.31 & .001 \\
\hline SCL agorafobie $(N=134)$ & 10,9 & $(5,1)$ & 9,4 & $(3,9)$ & 4.80 & .000 \\
\hline SCL depressie $(N=134)$ & 30,0 & $(10,6)$ & 26.1 & $(9,8)$ & 5.16 & .000 \\
\hline sociale steun $(N=113)$ & 49.1 & $(6,6)$ & 50,8 & $(6,8)$ & -2.56 & .012 \\
\hline kunnen praten over de aandoening ( $N=105)$ & 24,2 & $(4,8)$ & 25,5 & $(5,1)$ & -3.80 & .000 \\
\hline
\end{tabular}

Tabel 5.8. Gepaarde t-tests bij scores op aspecten van kwaliteit van leven bij opname en 6 maanden na ontslag

\begin{tabular}{|c|c|c|c|c|c|}
\hline & opname & \multicolumn{4}{|c|}{$\begin{array}{l}6 \text { maanden na } \\
\text { ontslag }\end{array}$} \\
\hline & $(S D)$ & $M$ & $(S D)$ & $t$ & $p$ \\
\hline \multicolumn{6}{|l|}{ ervaren beperkingen. } \\
\hline dagelijkse activiteiten $(N=114)$ & $6, \mathrm{i} \quad(1,9)$ & 5.5 & $(2,6)$ & 2.65 & .009 \\
\hline kortademigheid $(N=85)$ & $64.6(18.5)$ & $75,4($ & $(23,8)$ & -4.60 & .000 \\
\hline schaamie $(N=1 ! 6)$ & $16,7(7,0)$ & 15.3 & $(4,7)$ & 2.63 & .010 \\
\hline angst bij benauwdheid $(N=110)$ & $25,8(8,7)$ & 24.5 & $(8,8)$ & 2.09 & .039 \\
\hline NPV inadequatic $(N=116)$ & $16,2(8,9)$ & 15.7( & $(10,1)$ & .72 & .476 \\
\hline NPV sociale inadequatic $(N=116)$ & $11,8(7,6)$ & 10,9 & $(8,1)$ & 1.64 & .105 \\
\hline NPV zelfwaardering $(N=110)$ & $23,8(6,8)$ & 23.6 & $(6,5)$ & .38 & .707 \\
\hline $\mathrm{SCl}$ angst $(N=115)$ & $19.2(7.7)$ & 17,8 & $(7,2)$ & 2.20 & .030 \\
\hline $\mathrm{SCL}$ agorafobie $(N=115)$ & $10,8 \quad(5,1)$ & 9.9 & $(4,1)$ & 2.57 & .012 \\
\hline SCL depressie $(N=115)$ & $29,6(10,7)$ & 26.9( & $(10,0)$ & 3.26 & .001 \\
\hline sociale steun $(N=106)$ & $49,5(6,1)$ & 49,9 & $(7,1)$ & .81 & .417 \\
\hline kunnen praten over de aandoening $(N=101)$ & $24,8(4,6)$ & 24,8 & $(5,2)$ & .10 & .018 \\
\hline
\end{tabular}

Wanneer de scores, gemeten bij opname, worden vergeleken met die van 6 maanden na ontslag, blijken de kenmerken inadequatie, zelfwaardering en ervaren sociale steun gedurende het laatstgenoemde meetmoment geen gunstiger beeld te vertonen (tabel 5.8.). Op de overige kenmerken wordt 6 maanden na ontslag wel een gunstiger score aangetroffen. Vergeleken met de scores bij opname blijken de gemiddelde scores op het moment van 12 maanden na ontslag niel gunstiger aangaande de angst bij benauwdheid, zelfwaardering en de ervaren sociale steun (tabel 5.9.). 


\begin{tabular}{|c|c|c|c|c|}
\hline & opname & \multicolumn{2}{|c|}{$\begin{array}{l}12 \text { maanden na } \\
\text { ontslag }\end{array}$} & \multirow[b]{2}{*}{$p$} \\
\hline 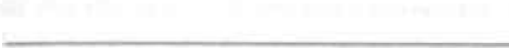 & $M(S D)$ & $M(S D)$ & $t$ & \\
\hline \multicolumn{5}{|l|}{ ervaren beperkingen } \\
\hline dagelijkse activiteiten $(\mathrm{N}=95)$ & $6.0(1.9)$ & $5,5(2.4)$ & 2.06 &, 042 \\
\hline kortademigheid $(\mathrm{N}=74)$ & $66.2(19.0)$ & $75,6(24,7)$ & -3.42 & .001 \\
\hline schaamte $(N=100)$ & $16.9(7.3)$ & $15,4(4,5)$ & 2.57 & .012 \\
\hline angst bij benauwdheid $(\mathrm{N}=94)$ & $26.3(8.2)$ & $25,4(9.5)$ & 1.19 & .239 \\
\hline NPV inadequatic $(N=100)$ & $16,5(8,9)$ & $14,9(9.9)$ & 2.13 & .036 \\
\hline NPV sociale inadequatie $(N=99)$ & $12,4(7,4)$ & $10,8(8,0)$ & 3.08 & .003 \\
\hline NPV zelfwaardering ( $N=101)$ & $23,3(7,0)$ & $23,9(7,1)$ & .79 & .429 \\
\hline $\mathrm{SCL}$ angst $(N=100)$ & $19,3(6,8)$ & $17.7(7.5)$ & 2.86 & .005 \\
\hline SCL agorafobie $(N=100)$ & $11,1(5,3)$ & $10.2(5,2)$ & 2.61 & 011 \\
\hline SCL depressie $(N=100)$ & $29.6(9,8)$ & $26,9(11.5)$ & 2.96 & .004 \\
\hline sociale steun $(\mathrm{N}=87)$ & $49,2(6,3)$ & $50,2(6,4)$ & -1.46 & .147 \\
\hline kunnen praten over de aandoening ( $\mathrm{N}=87)$ & $24.7(4,3)$ & $25,6(4,8)$ & -2.15 & .034 \\
\hline
\end{tabular}

Tabel 5.10. Aantallen en percentages patiènten dat 12 maanden na ontslag in vergelijking met opname in het NAD onveranderd scoorde, verbeterde of verslechterde op verschillende aspecten van " $k$ waliteit van leven"

\begin{tabular}{|c|c|c|c|c|c|c|}
\hline & \multicolumn{2}{|c|}{ verbeterd } & \multicolumn{2}{|c|}{ onverandend } & \multicolumn{2}{|c|}{ verslechterd } \\
\hline & $N$ & $\%$ & $N$ & $\%$ & $N$ & $\%$ \\
\hline \multicolumn{7}{|l|}{$\begin{array}{l}\text { FUNCTIONEEL } \\
\text { ervaren beperkingen }\end{array}$} \\
\hline dagelijkse activiteiten $(N=94)$ & 24 & 27 & 50 & 52 & 20 & 21 \\
\hline kortademigheid $(N=74)$ & 24 & 33 & 39 & 51 & 11 & 16 \\
\hline \multicolumn{7}{|l|}{ PSYCHOLOGISCH } \\
\hline schaamte $(N=100)$ & 22 & 22 & 58 & 58 & 20 & 20 \\
\hline angst bij benauwdheid $(N=99)$ & 25 & 27 & 55 & 58 & 15 & 15 \\
\hline \multicolumn{7}{|l|}{ NPV } \\
\hline inadequatie $(N=100)$ & 26 & 26 & 61 & 61 & 13 & 13 \\
\hline sociale inadequatic $(N=99)$ & 32 & 32 & 55 & 56 & 12 & 12 \\
\hline zelfwaardering $(N=101)$ & 20 & 20 & 55 & 54 & 26 & 26 \\
\hline \multicolumn{7}{|l|}{ SCL-90 } \\
\hline angst $(N=100)$ & 34 & 34 & 54 & 54 & 12 & 12 \\
\hline agorafobie $(N=100)$ & 35 & 35 & 53 & 53 & 12 & 12 \\
\hline depressie $(N=100)$ & 33 & 33 & 58 & 58 & 9 & 9 \\
\hline \multicolumn{7}{|l|}{ SOCIAAL } \\
\hline sociale steun $(N=87)$ & 19 & 22 & 44 & 50 & 24 & 28 \\
\hline kunnen praten over aandoening $(N=87)$ & 15 & 17 & 52 & 60 & 20 & 23 \\
\hline
\end{tabular}

In tabel 5.10. staan de aantallen en percentages vermeld van patiënten die in vergelijking met het moment van opname, op het moment van 12 maanden na ontslag respectievelijk blijken te zijn verbeterd, onveranderd zijn, of zijn verslechterd op variabelen die aspecten van kwaliteit van leven uitdrukken.Qua functioneel aspect blijkt dat $27 \%$ van de patienten is verbeterd op ervaren beperkingen in dagelijkse activiteiten. $50 \%$ scoort in dezelfde categorie als bij opname en $20 \%$ blijkt in een slechtere categorie te hebben gescoord. Voor wat betreft de kortademigheid is $33 \%$ verbeterd, terwijl $39 \%$ onveranderd heeft gescoord en $11 \%$ slechter. Inzake de ziektespecifieke psychologische kenmerken blijkt op de variabele die schaamte meet, $22 \%$ te zijn verbeterd, $58 \%$ onveranderd te hebben gescoord en $20 \%$ te zijn verslechterd. Op de variabele die de angst bij benauwdheid in kaart brengt scoorde $27 \%$ beter, $58 \%$ onveranderd en $15 \%$ 
slechter. Ook op de variabelen die de persoonlijkheidskenmerken inadequatie, sociale inadequatie en zelfwaardering uitdrukken en de variabelen die de psychische klachten angst, agorafobie en depressie meten, wordt door een meerderheid van de populatie in de onveranderde categorie gescoord (minimaal 53\%), terwijl 20 tot $35 \%$ van de onderzoeksgroep op deze variabelen in de verbeterde categorie scoort. 9 tot $26 \%$ blijkt in een verslechterde categorie te scoren. Het percentage dat is verbeterd op de variabele ervaren sociale steun is $18 \%$, terwijl $54 \%$ op deze variabele onveranderd scoort en $28 \%$ blijkt te zijn verslechterd. Ten slotte blijken de percentages patiënten die in de verbeterde, onveranderde en verslechterde scorecategorie vallen voor de variabele 'kunnen praten over de aandoening' respectievelijk $17 \%, 60 \%$ en $23 \%$ te zijn.

\subsection{Samenvatting en conclusies}

In dit hoofdstuk werden de resultaten gepresenteerd met betrekking tot de vraag naar het beloop van de kenmerken van de patiëntenpopulatie op aspecten van medische consumptie en kwaliteit van leven. Het betreft een antwoord op de tweede onderzoeksvraag. Bovendien werden als antwoord op de derde onderzoeksvraag aantallen en percentages van de patiëntenpopulatie gegeven die in vergelijking met het moment van opname in het NAD, op het moment van 12 maanden na ontslag bleken te zijn verbeterd, onveranderd zijn gebleven of zijn verslechterd op genoemde aspecten.

Uit de resultaten blijkt, dat de gemiddelde scores op de variabelen die medische consumptie en kwaliteit van leven meten bij ontslag gunstiger waren dan bij opname. De scores op de aspecten van kwaliteit van leven laten een gunstig beloop zien; zowel het functionele, het psychologische, als het sociale aspect van kwaliteit van leven vertoonde bij ontslag een gunstiger beeld dan bij opname. Tijdens de follow-up-momenten van 6 maanden en van 12 maanden na ontslag bleken de gemiddelde scores op de meeste variabelen nog steeds gunstiger dan bij opname. 6 maanden na ontslag bleken de inadequatie, zelfwaardering en sociale steun niet meer te verschillen ten opzichte van opname. 12 maanden na ontslag bleken in vergelijking met het moment van opname de patiënten niet meer gunstiger te scoren op de variabelen angst bij benauwdheid, zelfwaardering en sociale steun. Voor wat betreft de medische consumptie kan worden geconciudeerd dat de onderzoeksgroep in het jaar na ontslag uit het NAD minder ziekenhuisopnamen heeft ondergaan en minder dagen in een ziekenhuis heeft doorgebracht vanwege Cara dan gedurende het jaar voorafgaand aan opname in het NAD. Dit gold eveneens voor het aantal huisarts- en specialistbezoeken, hoewel hierbij een verlaagde score niet noodzakelijkerwijs een gunstiger score is. Ook het orale corticosteroïdgebruik bleek 12 maanden na ontslag te zijn verminderd ten opzichte van het moment van opname. Het gebruik van de inhalatiecorticosteroïden nam daarentegen toe. Echter, dit betreft een medicatievorm dat nauwelijks met bijverschijnselen gepaard gaat en als een noodzakelijk vervangingsmiddel kan dienen voor patiènten die voorheen waren aangewezen op orale corticosteroïden. Deze verschuiving kan derhalve worden beschouwd als een verbetering.

De bepaling van aantallen en percentages patiënten dat 12 maanden na ontslag bleek te zijn verbeterd, onveranderd is gebleven, of is verslechterd ten opzichte van het moment van ontslag leverde het volgende op: 17 to $33 \%$ van de patiënten is verbeterd op de verschillende variabelen die kwaliteit van leven uitdrukken, 50 tot $61 \%$ scoort hierop onveranderd en 9 tot $28 \%$ is verslechterd. Voor wat betreft de medische consumptie blijkt dat 33 tot $52 \%$ is verbeterd, 19 to $55 \%$ onveranderd is gebleven, en 10 tot $29 \%$ is verslechterd.

De resultaten die in dit hoofdstuk werden beschreven dienen te worden bezien tegen het licht 
van de doelstellingen van longrevalidatie in het NAD. Een belangrijke algemene doelstelling is het verbeteren van de kwaliteit van leven en de afname van de medische consumptic. Uit de resultaten is gebleken, dat het longrevalidatieprogramma van het NAD voor een deel van de onderzoeksgroep op aspecten heeft geleid tot de realisering van de beoogde doelen.

In het volgende hoofdstuk zal verslag worden gedaan van onderzoek naar determinanten van verbetering en van verslechtering op de variabelen 'ervaren beperkingen in dagelijkse activiteiten', artsconsulten, ziekenhuisopnamen, ziekenhuisdagen en oraal coricosteroïdgebruik. 



\subsection{Inleiding}

In de hoofdstukken 4 en 5 werden de kenmerken van de onderzoeksgroep en het beloop van deze kenmerken tot het moment van 12 maanden na ontslag beschreven. Uit de beschrijving komt naar voren, dat na een verblijf van gemiddeld drie maanden in het NAD gunstige veranderingen optreden binnen de gemeten aspecten van medische consumptie en binnen enkele van de kenmerken die verwijzen naar de kwaliteit van leven.

In dit hoofdstuk zal voor een aantal uitkomstvariabelen, te weten de aspecten van medische consumptie en de ervaren beperkingen in dagelijkse activiteiten worden nagegaan of deze kunnen worden voorspeld uit een aantal a-priori veronderstelde determinanten. In hoofdstuk drie werden deze variabelen reeds vermeld en werd de keuze ervan verantwoord.

De volgende vraagstellingen worden in dit hoofdstuk uitgewerkt:

1. Wat zijn determinanten van verbetering en van verslechtering op aspecten van medische consumptie en op de ervaren beperkingen in dagelijkse activiteiten?

2. In hoeverre hangt het veranderd zijn (in gunstige zin) op enkele psychologische en longfunctiekenmerken samen met de verbeteringen op de ervaren beperkingen in dagelijkse activiteiten en op enkele aspecten van medische consumptie, te weten de frequentie en de duur van ziekenhuisopnamen, het aantal dagen dat in een ziekenhuis moest worden doorgebracht vanwege Cara, en her oraal corticosteroïdgebruik?

In de hier navolgende paragrafen worden de resultaten met betrekking tot deze vierde en vijfde onderzoeksvraag gepresenteerd. Voor de gehanteerde methode kan worden verwezen naar hoofdstuk 3. Per uitkomstvariabele wordt telkens alleen dàt deel van de onderzoeksgroep bestudeerd dat op één van beide meetmomenten een score groter dan 0 behaalt: voor wat betreft de artsbezoeken minimaal één consult en de ziekenhuisopnamen minimaal één opname cq. één ziekenhuisdag. Aangaande het oraal corticosteroïdgebruik geldt, dat cen patiënt wordt ingedeeld in de onderzoeksgroep, wanneer hem of haar bij opname en/of 12 maanden na ontslag minimaal één tablet corticosteroïden à $5 \mathrm{mg}$, of een gedeelte daarvan, werd voorgeschreven (zie ook tabel 4.4. en 4.5., pag. 61).

\subsection{Determinanten van verbetering en verslechtering van aspecten van medische consumptie en ervaren beperkingen in het dagelijkse activiteiten}

In deze paragraaf wordt nagegaan in hoeverre de scores op de onafhankelijke variabelen verschillen ten aanzien van de scorecategorieën van de variabelen ervaren beperkingen in dagelijkse activiteiten, huisartsbezoek, specialistbezoek, frequentie van ziekenhuisopnamen, aantal dagen ziekenhuisopnamen en oraal corticosteroïdgebruik.

De afhankelijke variabelen die de ervaren beperkingen in dagelijkse activiteiten, de ziekenhuisopnamen en de ziekenhuisdagen uitdrukken, hebben respectievelijk de waarden 'verbeterd' en 'onveranderd/verslechterd' (determinanten van verbetering) of 'verslechterd', 'onveranderd/verbeterd' (determinanten van verslechtering). De variabelen huisartsbezoek en specialistbezoek hebben als waarden 'minder', 'onveranderd' en 'meer'. 
De resultaten van de analyses met betrekking tot de determinanten van een verbetering op de ervaren beperkingen in dagelijkse activiteiten staan weergegeven in de tabellen 6.1., 6.2. en 6.3..

Tabel 6.1. Variantieanalyse van scores op onafhankelijke variabelen met betrekking tot veranderingsscores op ervaren beperkingen in dagelijkse activiteiten $(N=95)$

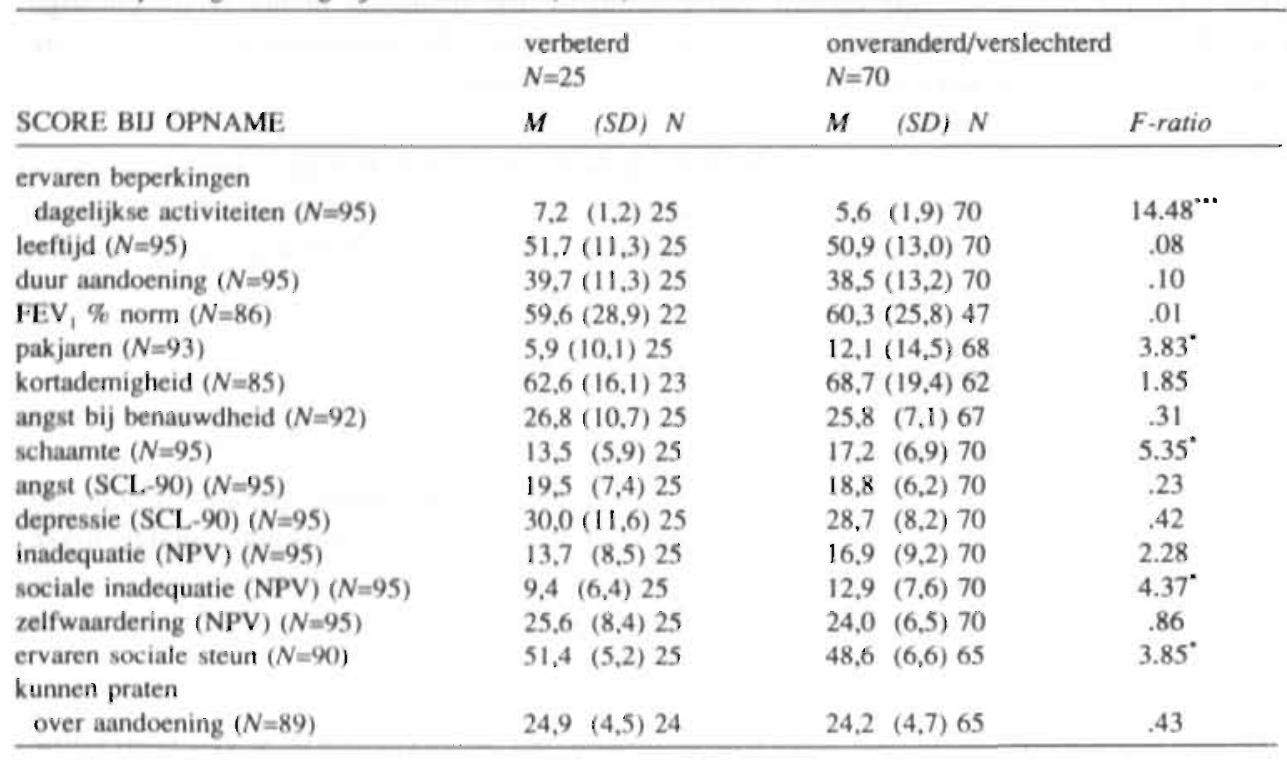

"p<.05; ${ }^{\cdots *} p<.001$

In de eerste plaats blijkı uit tabel 6.1., dat patiënten die zijn verbeterd qua ervaren beperkingen in dagelijkse activiteiten, bij opname een hogere en dus ongunstiger score hadden op de baselinemeting van deze variabele dan patiënten die tijdens de 12-maands follow-up in de onveranderde cq. verslechterde categoric bleken te scoren. Bovendien bleek de groep die is verbeterd minder te hebben gerookt dan de groep die niet is verbeterd. Verder had de verbeterde groep bij opname een gunstiger score op de variabele die schaamte omtrent de aandoening meet dan de groep die op ervaren beperkingen niet verbeterde. Ook op de variabelen die sociale inadequatie en ervaren sociale steun meten bleek bij opname gunstiger te zijn gescoord door de verbeterde groep.

In tabel 6.2. staan de resultaten van analyses met betrekking tot dichotome determinantvariabelen vermeld. De kenmerken geslacht, diagnose en burgerlijke staat, bleken het al dan niet verbeteren van de ervaren beperkingen niet te kunnen voorspellen. 
Tabel 6.2. Chi-kwadraatanalyse van aantallen patienten: geslacht, diagnose en burgerlijke staat met betrekking tot twee behandelresultatenniveaus van ervaren beperkingen in dagelijkse activiteiten ( $N=95$ )

\begin{tabular}{|c|c|c|c|c|c|}
\hline & \multicolumn{2}{|c|}{$\begin{array}{l}\text { verbeterd } \\
(N=25)\end{array}$} & \multicolumn{3}{|c|}{$\begin{array}{l}\text { onverandend/verslechterd } \\
(\mathrm{N}=75)\end{array}$} \\
\hline & $N$ & $\Phi$ & $N$ & $\%$ & $x^{2}$ \\
\hline \multicolumn{6}{|l|}{ geslacht } \\
\hline $\operatorname{man}(N=47)$ & 9 & 19 & 38 & 81 & 2.46 \\
\hline vrouw $(N=48)$ & 16 & 33 & 32 & 67 & \\
\hline \multicolumn{6}{|l|}{ diagnose } \\
\hline astma $(N=17)$ & 7 & 41 & 10 & 59 & 2.36 \\
\hline COPD $(N=77)$ & 18 & 23 & 60 & 77 & \\
\hline \multicolumn{6}{|l|}{ burgerlijke staat } \\
\hline samenwonend $(\mathrm{N}=64)$ & 15 & 23 & 49 & 77 & .60 \\
\hline alleenwonend ( $N=29)$ & 9 & 31 & 20 & 69 & \\
\hline
\end{tabular}

Uit correlatieanalyse komt naar voren dat de variabelen sociale inadequatic en schaamte positief met elkaar samenhangen (Pearson $r=35 ; p<.001$ ). De variabelen ervaren sociale steun en schaamte blijken een negatieve samenhang te vertonen (Pearson $r=-.32 ; p<.001$ ). Schaamte en ervaren beperkingen in dagelijkse activiteiten correleren positief met elkaar (Pearson $r=.24 ; p<.01$ ). Door middel van multiple regressieanalyse werd nagegaan welke van de variabelen de meeste verklaarde variantie vertoont met betrekking tot verandering in ervaren beperkingen in dagelijkse activiteiten. De scores op de variabelen ervaren beperkingen in dagelijkse activiteiten (baselinemeting), pakjaren, schaamte, sociale inadequatie en ervaren sociale steun werden stapsgewijs ingevoerd. De resultaten van deze analyse worden in tabel 6.3. weergegeven. De scores bij opname op de variabelen ervaren beperkingen in dagelijkse activiteiten en de scores op de variabele die schaamte meet bleken in de vergelijking te zijn opgenomen en derhalve de scores op de afhankelijke variabele te voorspellen.

Geconcludeerd kan worden dat een bij opname ongunstige score op ervaren beperkingen in dagelijkse activiteiten en gunstige score op de variabele die schaamte meet samenhang vertoont met een 12 maanden na ontslag geconstateerde verbetering op ervaren beperkingen in dagelijkse activiteiten.

Tabel 6.3. Multiple regressieanalyse op verschilscore (verbeterd versus niet verbeterd) op ervaren beperkingen dagelijkse activiteiten

\begin{tabular}{|c|c|c|c|}
\hline & Multiple $R$ & $R^{2}$ & $\beta$ \\
\hline \multicolumn{4}{|l|}{ ervaren beperkingen } \\
\hline dagelijkse activiteiten (bij opname) & .40 & 16 & $.45^{\cdots}$ \\
\hline schaamte & .51 & .26 & $.32 *$ \\
\hline
\end{tabular}

${ }^{*} p<01 ;{ }^{\cdots} p<.001$

\subsubsection{Determinanten van verslechtering van ervaren beperkingen in dagelijkse activiteiten}

In de tabellen 6.4. en 6.5. staan de resultaten vermeld van de: analyses met betrekking tot determinanten van een verslechtering op ervaren beperkingen in activiteiten van het dagelijks leven. 
Tabel 6.4. Variantieanalyse van scores op onafhankelijke variabelen met betrekking tot veranderingsscores op ervaren beperkingen in dagelijkse activiteiten $(N=95)$

\begin{tabular}{|c|c|c|c|c|c|}
\hline \multirow[b]{2}{*}{ SCORE BU OPNAME } & \multicolumn{2}{|c|}{$\begin{array}{l}\text { verslechterd } \\
(N=20)\end{array}$} & \multicolumn{3}{|c|}{$\begin{array}{l}\text { onveranderd/verbeterd } \\
(N=75)\end{array}$} \\
\hline & $M$ & (SD) $N$ & $M$ & $(S D) N$ & F-ratio \\
\hline \multicolumn{6}{|l|}{ ervaren beperkingen } \\
\hline dagelijkse activiteiten $(N=95)$ & 5,3 & $(0,7) 20$ & 6,2 & $(2,1) 75$ & 3.89 \\
\hline leeftijd $(N=95)$ & 51,7 & $(12,9) 20$ & 50,9 & $(12,5) 75$ & .06 \\
\hline duur aandoening $(N=80)$ & 31,1 & $(19.1) 18$ & 30.9 & $(17.9) 62$ & .00 \\
\hline FEV, \% norm $(N=86)$ & 69.4 & $(31,8) \cdot 17$ & 57,8 & $(24,7) 69$ & 2.68 \\
\hline pakjaren $(N=93)$ & 11,6 & $(11,2) 19$ & 10.1 & $(14,3) 74$ & .17 \\
\hline kortademigheid $(N=85)$ & 66,6 & $(12,8) 18$ & 67.2 & $(20,0) 67$ & .02 \\
\hline angst bij benauwdheid $(N=92)$ & 25.4 & $(6,6) 19$ & 26,3 & $(8,6) 73$ & .19 \\
\hline schaamte $(N=95)$ & 18,0 & $(6.8) 20$ & 15,7 & $(6,8) 75$ & 1.76 \\
\hline angst (SCl-90) $(N=95)$ & 21,2 & $(7.7) 20$ & 18.4 & $(6.1) 75$ & 2.96 \\
\hline depressie $(\mathrm{SCL}-90)(N=95)$ & 30,6 & $(8,7) 20$ & 28,6 & $(9.3) 75$ & .75 \\
\hline inadequatie (NPV) $(N=95)$ & 20.2 & $(9.7) 20$ & 15.0 & $(8,6) 75$ & $5.43^{\circ}$ \\
\hline sociale inadequatie (NPV) $(N=95)$ & 14,6 & $(8,2) 20$ & 11,3 & $(7,1) 75$ & 3.23 \\
\hline zelfwaardering (NPV) $(N=95)$ & 23,2 & $(6,4) 20$ & 24,8 & $(7.2) 75$ & .79 \\
\hline ervaren sociale steun $(N=90)$ & 48,5 & $(4,6) 20$ & 49,6 & $(6,8) 70$ & .52 \\
\hline kunnen praten over aandoening $(N=89)$ & 21,9 & $(4,2) 18$ & 25,0 & $(4,5) 71$ & $6.55^{\circ}$ \\
\hline
\end{tabular}

$p<.05 ;{ }^{\cdots *} p<001$

Uit tabel 6.4. blijkt, dat patiẹnten die 12 maanden na ontslag zijn verslechterd qua ervaren beperkingen in dagelijkse activiteiten, bij opname ongunstiger scoorden op de variabelen die 'inadequatie' en 'kunnen praten over de aandoening' meten.

De variabelen geslacht, diagnose en burgerijke staat (niet opgenomen in de tabei) blijken geen verband te hebben met het al dan niet verslechterd zijn op deze afhankelijke variabele.

Tabel 6.5. Multiple regressieanalyse op verschilscore (verslechterd versus niet verslechterd) ervaren beperkingen dagelijkse activiteiten.

\begin{tabular}{llll}
\hline & Multiple $R$ & $R^{2}$ & $\beta$ \\
\hline & & & \\
kunnen praten over de aandoening & .27 & .07 & $-.24^{*}$ \\
inadequatie & .34 & .12 & $.21^{*}$ \\
\hline
\end{tabular}

$p<.05$

Tabel 6.5. toont het resultaat van multiple regressieanalyse. Hieruit blijken de variabelen 'kunnen praten over de aandoening' en 'inadequatie' het al dan niet verslechterd zijn qua ervaren beperkingen in dagelijkse activiteiten te kunnen voorspellen. Patiënten met een ongunstige score op de variabele 'kunnen praten over de aandoening' en de op de variabele 'inadequatie', hebben meer kans op een verslechtering in ervaren beperkingen in dagelijkse activiteiten.

\subsubsection{Determinanten van verandering van het aantal huisartsbezoeken}

De resultaten van variantieanalyse van de scores van mogelijke determinantvariabelen met betrekking tot 'minder' huisartsbezoeken en 'onveranderd/meer' huisartsbezoeken, worden in tabel 6.6. weergegeven. In tabel 6.7. wordt het resultaat van deze analyses aangaande de 
scoringscategorieèn 'meer' huisartsbezoeken en 'onveranderd/minder' huisartsbezoeken gepresenteerd.

Uit de tabellen 6.7. en 6.8. blijkt dat alleen de baselinescore (frequentie huisartsbezoek in de periode van 1 jaar vóór opname in het NAD) verschilt met betrekking tot 'minder' cq. 'meer' huisartsbezoeken. De patiēntengroep die meer huisartsbezoeken had dan voor opname, bezocht de huisarts in de periode van één jaar voor opname minder vaker dan de groep patiènten die een onveranderd aantal of minder huisartsbezoeken had. Omgekeend geldt, dat de patiěntengroep die in de periode van één jaar na ontslag minder huisartsbezoeken had, in vergelijking met de groep patiënten die een onveranderd aantal of meer huisartsbezoeken had, de huisarts in het jaar voorafgaande aan opname vaker bezocht. De scores op de overige bestudeerde variabelen, waaronder de dichotome variabelen geslacht, diagnose en burgerlijke staat (niet in de tabel opgenomen), bleken geen significante verschillen te vertonen.

Tabel 6.6. Varianticanalyse van scores op onafhankelijke variabelen met betrekking tot veranderingsscores (minder cq. onveranderd/meer) van de frequentie van huisartbezoek ( $N=123)$

\begin{tabular}{|c|c|c|c|c|c|}
\hline \multirow[b]{2}{*}{ SCORE BU OPNAME } & \multicolumn{2}{|c|}{$\begin{array}{l}\text { minder } \\
N=47\end{array}$} & \multicolumn{3}{|c|}{$\begin{array}{l}\text { onveranderd/meer } \\
N=76\end{array}$} \\
\hline & M & (SD) $N$ & & (SD) $N$ & F-ratio \\
\hline huisartsbezoek I jr vóór opname ( $\mathrm{N}=123)$ & 13,3 & $3(16,8) 47$ & 3,1 & $(4,3) 76$ & $25.09^{\cdots \cdots}$ \\
\hline leeftijd $(N=123)$ & 51,6 & $(12,2) 47$ & 52,2 & $(13,0) 76$ & .08 \\
\hline duur aandoening $(N=100)$ & 22,8 & $3(17,2) 38$ & 21.9 & $(17,6) 62$ & 07 \\
\hline FEV, $\%$ norm $(N=114)$ & 59,2 & $(22,6) 46$ & 62,4 & $(24,9) 68$ & 51 \\
\hline kortademigheid $(N=107)$ & 61,2 & (19.8) 39 & 66,9 & $(19,7) 68$ & 2.03 \\
\hline $\begin{array}{l}\text { pakjaren }(N=121) \\
\text { ervaren beperkingen }\end{array}$ & 9,0 & $(15,1) 47$ & & $(11,3) 74$ & .08 \\
\hline dagelijkse activiteiten $(N=121)$ & 6.2 & $(1,9) 46$ & 6.1 & (1.9) 75 & .16 \\
\hline angst bij benauwdheid $(N=120)$ & 25,6 & $(8,8) 46$ & 24,4 & $(8,5) 74$ & .54 \\
\hline schạamte/stigma( $(N=\mathrm{i} 22)$ & 14,9 & $(7,4) 46$ & 17,2 & $(7,2) 76$ & $3.03^{\prime}$ \\
\hline angst (SCL-90) $(N=122)$ & 18,6 & $(6,2) 47$ & 18.4 & $(7.4) 76$ & .02 \\
\hline depressie (SCL-90) $(N=123)$ & 28,8 & $(9,1) 47$ & 29.6 & $(10.7) 76$ & .21 \\
\hline inadequatie (NPV) $(N=123)$ & 16.5 & $(9.1) 47$ & 16.4 & $(9,0) 76$ & .00 \\
\hline sociale inadequatie $(\mathrm{NPV})(N=123)$ & 11.6 & $(7,2) 47$ & 11,6 & $(8,2) 76$ & .00 \\
\hline zelfwaardering (NPV) $(N=123)$ & 24,7 & $(7,4) 47$ & 23,8 & $(6,2) 76$ & .45 \\
\hline ervaren sociale steun $(N=114)$ & 48,6 & $(7,1) 42$ & 49,3 & $(6.1) 72$ & .30 \\
\hline kunnen praten over aandoening ( $N=1[1)$ & 23,6 & $(5,5) 45$ & 23,9 & $(4,8) 66$ & .09 \\
\hline
\end{tabular}

${ }^{\prime} p<10 ; \cdots p<.001$ 
Tabel 6.7. Varianticanalyse van scores op onafhankelijke variabelen met betrekking tot veranderingsscores (meer cq. onveranderd/minder) van de frequentie van huisartbezoek $(N=123)$

\begin{tabular}{|c|c|c|c|c|c|}
\hline \multirow[b]{2}{*}{ SCORE BU OPNAME } & \multicolumn{2}{|c|}{$\begin{array}{l}\text { meer } \\
N=26\end{array}$} & \multicolumn{3}{|c|}{$\begin{array}{l}\text { onveranderd/minder } \\
N=97\end{array}$} \\
\hline & M & (SD) $N$ & & (SD) $N$ & F-ratio \\
\hline huisartsbezoek 1 jr vóór opname $(N=123)$ & 1,5 & $(1,8) 26$ & 8,5 & $(13,1) 97$ & $7.39^{* *}$ \\
\hline leeftijd $(\mathrm{N}=123)$ & 53,0 & $(14,3) 26$ & 51,7 & $(12,3) 97$ & .23 \\
\hline duur aandoening $(N=100)$ & 22.1 & $(18.9) 21$ & 22,2 & $(17,0) 79$ & .00 \\
\hline $\mathrm{FEV}_{1} \%$ norm $(N=114)$ & 55.9 & $(20,7) 24$ & 62,5 & $(24.7) 90$ & 1.45 \\
\hline kortademigheid $(N=107)$ & 70,6 & $(20,5) 23$ & 63,2 & $(19,4) 84$ & 2.56 \\
\hline pakjaren $(N=121)$ & 7.7 & $(10,9) 24$ & 8.9 & $(13,3) 97$ & .18 \\
\hline \multicolumn{6}{|l|}{ ervaren beperkingen } \\
\hline dagelijkse activiteiten $(N=121)$ & 5,8 & $(2,0) 26$ & 6,2 & $(1,8) 95$ & 1.09 \\
\hline angst bij benauwdheid $(N=120)$ & 25,6 & $(8,3) 26$ & 24,6 & $(8,7) 94$ & .25 \\
\hline schaamte/stigma $(N=122)$ & 16.7 & $(7,4) 26$ & 16,2 & $2(7,3) 96$ & 0.12 \\
\hline angst (SCL-90) $(N=122)$ & 18,2 & $(6,4) 26$ & 18.6 & $(7,1) 97$ & .08 \\
\hline depressie (SCL-90) $(N=123)$ & 28,0 & (7.9) 26 & 29.7 & $(10.6) 97$ & .59 \\
\hline inadequatic (NPV) $(N=123)$ & 14,9 & $(8.4) 26$ & 16,8 & $(9.1) 97$ & .93 \\
\hline sociale inadequatie $(\mathrm{NPV})(\mathrm{N}=123)$ & 10.7 & $(8,4) 26$ & 11,8 & $8(7,7), 97$ & .42 \\
\hline zelfwaardering (NPV) $(N=123)$ & 24,5 & $(5,5) 26$ & 24.0 & $(7,0) 97$ & .11 \\
\hline ervaren sociale steun $(N=114)$ & 50,3 & $(5,7) 26$ & 48,7 & $(6,6) 88$ & 1.37 \\
\hline kunnen praten over aandoening $(N=111)$ & 24,1 & $(6,2) 24$ & 23.7 & $(4,7) 87$ & .08 \\
\hline
\end{tabular}

$\cdots p<.001$

\subsubsection{Determinanten van verandering van het aantal specialistbezoeken}

Op dezelfde wijze als in paragraaf 6.3.2. aangaande het aantal huisartsbezoeken worden in deze paragraaí de resultaten van determinantanalyses met betrekking tot veranderingsscores van specialistbezoeken gepresenteerd.

Uit tabel 6.8. bleken de scores met betrekking tot het aantal specialistbezoeken voorafgaand aan opname in het NAD, de FEV , en de ervaren beperkingen te verschillen als het gaat om de scorecategorieën "minder" en "onveranderd/meer" specialistbezoeken.

Uit correlatieanalyse blijki dat de scores op deze variabelen geen onderling verband vertonen. Multiple regressieanalyse, waarbij de scores op deze variabelen stapsgewijs werden ingevoerd leverde op dat alleen de score van specialistbezoek voorafgaand aan opname de variantie verklaart $\left(R=38 ; R^{2}=14 ; \beta=-38 ; p<.001\right)$. Derhalve kan worden geconcludeerd dat minder specialistbezoeken in het jaar na ontslag uit het NAD yoor deze onderzoeksgroep kon worden voorspeld uit het aantal specialistbezoeken in het jaar voorafgaand aan opname in het NAD. De patiëntengroep die minder specialistbezoeken had na ontslag, had voorafgaand aan opname meer bezoeken dan de groep die even veel en meer bezoeken hadden. 
Tabel 6.8. Variantieanalyse van scores op onafhankelijke variabelen met betrekking tot veranderingseores (minder eq. onveranderd/meer) van de frequentic van specialistbezoek ( $\mathrm{N}=116)$

\begin{tabular}{|c|c|c|c|c|c|}
\hline \multirow[b]{2}{*}{ SCORE BU OPNAME } & \multicolumn{2}{|c|}{$\begin{array}{l}\text { minder } \\
N=46\end{array}$} & \multicolumn{2}{|c|}{$\begin{array}{l}\text { onveranderd/meer } \\
N=70\end{array}$} & \multirow[b]{2}{*}{ F-ratio } \\
\hline & $M$ & (SD) $N$ & M & (SD) $\mathrm{N}$ & \\
\hline specialistbezoek voór opname ( $\mathrm{N}=$ I I6) & 9.0 & $(3.5) 46$ & 5,8 & $(4,2) \cdot 70$ & $19.13^{\cdots *}$ \\
\hline leeftijd $(N=116)$ & 50.6 & $(13,6) 46$ & 51,4 & $(13,0) 70$ & 11 \\
\hline duur aandoening $(N=94)$ & 19.1 & $(18.1) 38$ & 20.4 & $(15.1) 56$ & 13 \\
\hline $\mathrm{FEV}_{1}$ \% norm $(\mathrm{N}=106)$ & 69.6 & $(27,9) 41$ & 58,4 & $(23.5) 65$ & $4.96^{\circ}$ \\
\hline kortademigheid $(N=100)$ & 69.5 & $(22,8) 39$ & 65.2 & $(19,0) 61$ & 1.05 \\
\hline pakjaren $(N=113)$ & 6,6 & $(9,3) 45$ & 9.8 & $(14,1) 69$ & 1.79 \\
\hline \multicolumn{6}{|l|}{ ervaren beperkingen } \\
\hline dagelijkse activiteiten $(\mathrm{N}=111)$ & 5,7 & $(1,7) 44$ & 6.3 & $(2,0) 68$ & $2.96^{\prime}$ \\
\hline angst bij benauwdheid $(N=110)$ & 26.3 & $(8,1) 44$ & 25.4 & $(8,7) 66$ & .27 \\
\hline schaamte/stigma $(N=114)$ & 15,4 & $(6,6) 46$ & 16.8 & $(7,5) 68$ & 1.14 \\
\hline angst (SCL-90) $(N=115)$ & 18.0 & $(6.4) 46$ & 19.6 & $(7.6) 69$ & 1.40 \\
\hline depressie (SCL-90) $(\mathrm{N}=[15)$ & 28,4 & $(8.1) 46$ & 29.9 & $(11.1) 69$ & .64 \\
\hline inadequatie (NPV) $(\mathrm{N}=115)$ & 15.9 & $(9,5) 46$ & 17,0 & $(8,8) 69$ & .37 \\
\hline sociale inadequatie (NPV) $(\mathrm{N}=115)$ & 11.7 & $(7,3) 46$ & 11.5 & $(7.7) 69$ & .07 \\
\hline zelfwaardering (NPV) $(N=115)$ & 23,1 & $(6,8) 46$ & 24,7 & $(7,2) 69$ & 1.49 \\
\hline ervaren sociale steun $(N=107)$ & 48,6 & $(7.2) 43$ & 49,0 & $(5.8) 64$ & .11 \\
\hline kunnen praten over aandoening $(N=104)$ & 23,6 & $(5,5) 43$ & 23,5 & $(4,8) 64$ & 02 \\
\hline
\end{tabular}

"pe, 10;" p<,05; "*. p<.001

Tabel 6.9. Variantieanalyse van scores op onafhankelijke variabelen met betrekking tot veranderingsscores (meer cq. onveranderd/minder) van de frequentie van specialistbezoek $(N=116)$

\begin{tabular}{|c|c|c|c|c|c|}
\hline \multirow[b]{2}{*}{ SCORE BU OPNAME } & \multicolumn{2}{|c|}{$\begin{array}{l}\text { meer } \\
N=29\end{array}$} & \multicolumn{2}{|c|}{$\begin{array}{l}\text { onveranderd/minder } \\
N=87\end{array}$} & \multirow[b]{2}{*}{ F-ratio } \\
\hline & M & $(S D) N$ & $M$ & $(S D) N$ & \\
\hline specialistbezoek vóór opname $(N=116)$ & 4.8 & $(1,7) 29$ & 7,8 & $(4.5) 87$ & $12.72^{\cdots *}$ \\
\hline leeftijd $(N=116)$ & 52.5 & (10.9) 29 & 50.7 & $(13.9) 87$ & .41 \\
\hline duur aandoening $(N=94)$ & 23,2 & (16.7) 22 & 18.9 & $(16,1) 72$ & 1.19 \\
\hline FEV, \% norm $(N=106)$ & 57,0 & $(23,3) 27$ & 64.7 & $(26.4) 79$ & 1.83 \\
\hline kortademigheid $(N=100)$ & 62,6 & $(18,6) 24$ & 68.2 & $(2 I .1) 76$ & 1.37 \\
\hline pakjaren $(N=113)$ & 9.41 & $(14,1) 29$ & 6,1 & $(7,9) 85$ & 1.49 \\
\hline \multicolumn{6}{|l|}{ ervaren beperkingen } \\
\hline dagelijkse activiteiten $(N=111)$ & 6,6 & $(1,7) 29$ & 5.9 & $(2,0) 83$ & $3.16^{\prime}$ \\
\hline angst bij benauwdheid $(N=110)$ & 26.7 & $(8.5) 28$ & 22.9 & $(7,6) 82$ & $4.52^{\circ}$ \\
\hline schaamte/stigma $(N=114)$ & 16,3 & $(5.9) 29$ & 16,2 & $(7,6) 85$ & .01 \\
\hline angst (SCL-90) $(N=115)$ & 19.5 & $(8.2) 29$ & 18.8 & $(6,8) 86$ & .18 \\
\hline depressie (SCL-90) $(N=115)$ & 28,0 & $(9.6) 29$ & 29.7 & $(10.1) 86$ & .66 \\
\hline inadequatie (NPV) $(N=115)$ & 16.9 & $(9,4) 29$ & 15,5 & $(8,1) 86$ & .55 \\
\hline sociale inadequatie (NPV) $(N=115)$ & 11.2 & $(7.5) 29$ & 11.8 & $(7,7) 86$ & .15 \\
\hline zelfwaardering (NPV) $(N=115)$ & 24.5 & $(6.9) 29$ & 24,0 & $(7,1) 86$ & .12 \\
\hline ervaren sociale steun $(N=107)$ & 48,2 & $(5,1) 25$ & 49.0 & $(6,8) 82$ & .26 \\
\hline kunnen praten over aandoening $(N=104)$ & 22,8 & $(5,1) 28$ & 23,8 & $(5,0) 76$ & .70 \\
\hline
\end{tabular}

'p<10;" $p<05 ;{ }^{\cdots *} p<001$ 
Uit tabel 6.9. blijkt, dat de scores op het aantal specialistbezoeken voorafgaand aan: opname in het NA.D, de ervaren beperkingen in dagelijkse activiteiten en de angst bij benauwdheid verschilden met betrekking to 'meer' en 'onveranderd/minder' specialistbezoeken.

Uit correlatieanalyse kwam vervolgens naar voren dat de scores op deze variabelen onderling niet samenhingen.

Multiple regressieanalyse (tabel 6.10.) leidt tot de conclusie dat het al dan niet méér specialistbezoeken hebben in het jaar volgend op ontslag in vergelijking met het jaar voorafgaand aan opname in het NAD kon worden voorspeld uit het aantal specialistbezoeken voorafgaand aan opname en uit de mate van angsi bij benauwdheid bij opname. Patiënten die meer specialistbezoeken brachten vertoonden minder angst bij benauwdheid dan patiènten die even veel of minder' specialistbezoeken brachiten.

Tahel 6.10. Multiple regressieanalyse op verschilscore ('meer' vs. 'minder/onveranderá) van specialistbezoek

\begin{tabular}{llll}
\hline & Multiple $R$ & $R^{2}$ & $\beta$ \\
\hline specialistbezoek én jaar & & & \\
vór opname in het NAD & .31 & .10 & $-.34^{\cdots}$ \\
angst bij benauwdheid & .40 & .26 & $-.25^{*}$ \\
\hline
\end{tabular}

${ }_{p<01:} \cdots p<, 001$

\subsubsection{Determinanten van verbetering van het aantal ziekenhuisopnamen}

De tabe!len 6.11. en 6.12. Ionen de scores van de onafhankelijke variabelen met betrekking tolt de het al dan niet verbeterd zijn qua Îrequentie van ziekenhuisopnamen. Hieruit blijken de baselinemeting van het aantal ziekenihuisopnamen, de kortademigheid en het aanta! pakjaren significant verschillende scores te vertonen. De populatie die is verbeterd op de frequentie van ziekenihuisopnamen bleek een ongunstigei score te hebben op de variabele die kortademigheid meet dan de groep die evenveel of méér ziekenhuisopnamen had. Bovendien blijk.t de verbeterde groep minder' te hebben gerookı. De groep van patiënten die minder ziekenhuisopnamen hadden in vergelijking mel het jaar voorafgaand aan opname in het NAD hadden gemiddeld $6,9 \pm 13,0$ pakjaren, terwijil degenen die hierop niet waren verbeterd gemiddeld $12,0 \pm 13,9$ pakjaren hadden. Bovendien blijkt dat de patiënten die qua ziekenhuisopnamen zijn verbeterd minder schaamte te vertonen dan degenen die hierop niet zijn verbeterd. 
Tabel 6.11. Variantieanalyse van scores op onafhankelijke variabelen met betrekking tot veranderingsscores op de frequentie van zickenhuisopnamen ( $\mathrm{N}=75$ )

\begin{tabular}{|c|c|c|c|c|c|}
\hline \multirow[b]{2}{*}{ SCORE BU OPNAME } & \multicolumn{2}{|c|}{$\begin{array}{l}\text { verbeterd } \\
N=39\end{array}$} & \multicolumn{3}{|c|}{$\begin{array}{l}\text { onverandend/verslechterd } \\
N=36\end{array}$} \\
\hline & & (SD) $\mathrm{N}$ & M & (SD) $\mathrm{N}$ & F-ratio \\
\hline ziekenhuisopnamen vớr opname $(\mathrm{N}=75)$ & 2.3 & (1.3) 39 & 1.2 & $(1.6) 36$ & $11.27^{\cdots \cdots}$ \\
\hline leeftijd $(N=75)$ & 51,2 & $(12,9) 39$ & 47,4 & $(14,0) 36$ & 1.43 \\
\hline duur aandoening $(N=61)$ & 22,9 & $(20,2) 31$ & 19,3 & $(18,0) 30$ & 0.52 \\
\hline$F E V$, o norm $(\mathrm{N}=68)$ & 64,2 & $(26,7) 36$ & 65.1 & $(59.6) 32$ & .50 \\
\hline kontademigheid $(\mathrm{N}=63$ ) & 59,6 & $(18,6) 31$ & 68,9 & $(18,1) 32$ & $4.04^{*}$ \\
\hline pakjaren $(N=75)$ & $6,9($ & $(13.0) 39$ & 12,0 & $(13.9) 36$ & 2.77 \\
\hline \multicolumn{6}{|l|}{ ervaren beperkingen } \\
\hline dagelijkse activiteiten $(\mathrm{N}=73)$ & 5.9 & $(2,0) 37$ & 6,1 & $(1.9) 36$ & .17 \\
\hline angst bij benauwdheid ( $\mathrm{N}=71$ ) & 26.2 & $(8.5) 36$ & 26.2 & $(8,5) 35$ & 00 \\
\hline schaamte/stigma $(N=74)$ & 15,1 & $(5,8) 38$ & 17,8 & $(8,3) 36$ & 2.65 \\
\hline angst $(\mathrm{SCL}-90)(\mathrm{N}=74)$ & 19,0 & $(7,6) 38$ & 18,6 & $(7.8) 36$ & .06 \\
\hline depressie (SCL-90) (N=74) & 30.7 & $(10.1) 38$ & 30,0 & (11.2) 36 & .05 \\
\hline inadequatie (NPV) $(N=74)$ & 17,4 & $(7.6) 38$ & 16.9 & $(9.9) 36$ & .05 \\
\hline sociale inadequatie (NPV) $(N=74)$ & 12.2 & $(6.9) 38$ & 12,1 & $(7,8) 36$ & .00 \\
\hline zelfwaardering (NPV) $(\mathrm{N}=74)$ & 23,4 & $(6.9) 38$ & 25.1 & $(7,6) 36$ & 98 \\
\hline ervaren sociale steun $(N=69)$ & 49.0 & $(5,4) 35$ & 48,6 & $(7.2) 34$ & .09 \\
\hline kunnen praten over aandoening ( $N=66$ ) & 23.6 & $(5,2) 32$ & 23,9 & $(4.8) 34$ & .06 \\
\hline
\end{tabular}

${ }^{\prime} p<$ 10: ${ }^{\circ} p<05 ;{ }^{\cdots-} p<001$

Uit correlatieanalyse blijkt dat het aantal ziekenhuisopnamen, de kortademigheid, de schaamte en het aantal pakjaren onderling niet samenhangen. Multiple regressieanalyse, waarbij de scores. van de baselinemeting van ziekenhuisopnamen, de kortademigheid en de pakjaren stapsgewijs werden ingevoerd, toont dat alleen de baselinemeting en de pakjaren in het model worden opgenomen, wat betekent dat deze variabelen het al dan niet verbeterd zijn qua aantal ziekenhuisopnamen het meeste voorspellen (tabel 6.13.).

Tabel 6.12. Chi-kwadraatanalyse van aantallen patiënten: geslacht, diagnose en burgerlijke staat met betrekking tot twee behandelresultatenniveaus van de frequentie van ziekenhuisopnamen $(N=75)$

\begin{tabular}{|c|c|c|c|c|c|}
\hline & \multicolumn{2}{|c|}{ verbeterd } & \multicolumn{3}{|c|}{ onveranderd/verslechterd } \\
\hline & $N$ & $\%$ & $N$ & $\%$ & $x^{2}$ \\
\hline geslacht $(N=75)$ & & & & & .01 \\
\hline $\operatorname{man}(N=35)$ & 18 & 51 & 17 & 49 & \\
\hline vrouw $(N=40)$ & 21 & 55 & 19 & 45 & \\
\hline diagnose $(N=75)$ & & & & & .18 \\
\hline astma $(N=14)$ & 8 & 57 & 6 & 43 & \\
\hline $\operatorname{COPD}(N=61)$ & 31 & 51 & 30 & 49 & \\
\hline burgerlijke staat $(N=74)$ & & & & & .26 \\
\hline samenwonend $(N=43)$ & 21 & 49 & 22 & 51 & \\
\hline alleenwonend $(N=31)$ & 17 & 55 & 14 & 45 & \\
\hline
\end{tabular}

Geconcludeerd kan worden dat patiënten die een hoge score hadden op het aantal ziekenhuisopnamen en die veel hebben gerookt, een geringere kans hadden op verbetering van het aantal ziekenhuisopnamen dan patiënten die minder ziekenhuisopnamen hadden en weinig of niet hadden gerookt. 
Tabel 6.13. Multiple regressieanalyse op verschilscore van ziekenhuisopnamen

\begin{tabular}{llll}
\hline & Multiple $R$ & $R^{2}$ & $\beta$ \\
\hline ziekenhuisopnamen één jaar & & & \\
vór opname in het NAD & .46 & .21 & $-.47^{* *}$ \\
pakjaren & .51 & .26 & $.22^{*}$ \\
\hline
\end{tabular}

" $p<.05: \cdots p<.001$

\subsubsection{Determinanten van verslechiering van het aantal ziekenhuisopnamen}

Vervolgens werd nagegaan wat determinanten zijn van een verslechtering van het aantal ziekenhuisopnamen. Uit variantieanalyses blijkit dat een verslechtering hiervan alleen kon worden voorspeld uit het aantal ziekenhuisopnamen in het jaar voorafgaand aan opname in het NAD. Patiënten die bleken te zijn verslechterd qua aantal ziekenhuisopnamen, hadden voorafgaand aan opname in het NAD minder ziekenhuisopnamen dan patiënten die waren verbeterd of onveranderd waren bleven op deze afhankelijke variabele $(F=41,91 ; p<.001)$. De overige variabelen bleken hierop niet van invloed.

\subsubsection{Determinanten van verbetering van het aantal ziekenhuisdagen}

De tabellen 6.14. en 6.15. geven de scores op de onafhankelijke variabelen weer met betrekking tot de groepen patiënten die ten opzichte van het jaar vóór opname in het NAD, in het jaar na ontslag uit het NAD respectievelijk zijn verbeterd en niet zijn verbeterd qua aantal dagen dat ze werden opgenomen in een ziekenhuis in verband met Cara.

tabel 6.14. Variantieanalyse van scores op onafhankelijke variabelen met betrekking tot veranderingsscores op het aantal ziekenhuisdagen $(N=93)$

\begin{tabular}{|c|c|c|c|c|c|}
\hline \multirow[b]{2}{*}{ SCORE BIJ OPNAME } & $\begin{array}{l}\text { verbeterd } \\
N=46\end{array}$ & \multicolumn{3}{|c|}{$\begin{array}{l}\text { onveranderd/ } \\
\text { verslechterd } \\
N=47\end{array}$} & \multirow[b]{2}{*}{ F-ratio } \\
\hline & $M \quad(S D)$ & $M$ & $(S D)$ & $N$ & \\
\hline ziekenhuisdagen vór opname $(N=93)$ & $47.9(36.6) 46$ & 20,0 & $(39.4)$ & 47 & $12.78^{\cdots}$ \\
\hline leeftijd $(N=93)$ & $53,0(12,5) 46$ & 45.9 & $(12.5)$ & 47 & $7.40^{* *}$ \\
\hline duur aandoening $(N=74)$ & $24.1(19.5) 38$ & 20.1 & $(16,2)$ & 36 & .91 \\
\hline FEV, $\%$ norm $(N=86)$ & $59.3(22,9) 42$ & 64,6 & $(27,3)$ & 44 & .96 \\
\hline kortademigheid $(N=77)$ & $61.7(20.8) 35$ & 68,0 & $(18.6)$ & 42. & 1.91 \\
\hline pakjaren $(N=93)$ & $5,5(12,1) 46$ & 11,0 & $(13,0)$ & 47 & $4.58^{\circ}$ \\
\hline \multicolumn{6}{|l|}{ ervaren beperkingen } \\
\hline dagelijkse activiteiten $(N=90)$ & $5,9(2,2) 43$ & 6,1 & $(1,8) 4$ & 47. & .26 \\
\hline angst bij benauwdheid $(N=89)$ & $25,9 \quad(7,7) 44$ & 24.8 & $(8,8)$ & 45 & .45 \\
\hline schaamte $(N=91)$ & $16,3(5,7) 44$ & 16.7 & $(7.9)$ & 47 & .09 \\
\hline angst $(\mathrm{SCL}-90)(\mathrm{N}=92)$ & $19.6 \quad(7,2) .45$ & 17.9 & $(7,5)$ & 47 & 1.14 \\
\hline depressie (SCL-90) $(N=92)$ & $31,7(10,3) 45$ & 24,1 & $(10,2)$ & 47 & $2.84 !$ \\
\hline inadequatie (NPV) $(N=92)$ & $19,7(7,8), 45$ & 14,7 & $(9.5)$ & 47 & $7.44^{* *}$ \\
\hline sociale inadequatie (NPV) $(\mathrm{N}=92)$ & $12,0 \quad(7,1) 45$ & 11,2 & $(7,5)$ & 47 & .31 \\
\hline zelfwaardering (NPV) $(N=92)$ & $23,6(8,1) 45$ & 24,9 & $(6,2)$ & 47 & .79 \\
\hline ervaren sociale sieun $(N=84)$ & $49,1 \quad(5,4) 40$ & 48.4 & $(7,6)$ & 44 & .23 \\
\hline kunnen praten over aandoening $(N=83)$ & $23,4(4,8) 40$ & 23.6 & $(5.1)$ & 43 & .03 \\
\hline
\end{tabular}

${ }^{p} p<.10 ;{ }^{*} p<.05 ;{ }^{*} p<.01 ;{ }^{\cdots+} p<.001$ 
Uit tabel 6.14. blijkt, dat patiënten die waren verbeterd op deze afhankelijke variabele, meer dagen in een ziekenhuis hadden doorgebracht in het jaar voorafgaand aan opname dan degenen die hierop niet waren verbetend. Bovendien bleek de verbeterde groep een hogere leeftijd te hebben. Ook het aantal pakjaren laat voor de twee groepen verschillende scores zien: de groep die is verbeterd op het aantal ziekenhuisdagen had minder pakjaren dan de groep die hierop niet verbeterde. Ook had de verbeterde groep een ongunstiger score op de variabelen depressie en een ongunstiger score op de variabele inadequatie.

Uit tabel 6.15. blijkt, dat procentueel iets meer astma- dan COPD-patiènten waren verbeterd qua aantal ziekenhuisdagen. Wordt bij deze afhankelijke variabele niet uitgegaan van een indeling in categorieèn, maar van continue scores dat blijkt bij vergelijking het gemiddeld verminderd aantal ziekenhuisdagen bij de astmapopulatie $(N=21) 31,1 \pm 47,6$ te zijn en voor de COPD-populatic $(N=72) 12,2 \pm 46,3$ dagen (Mann-Whitney $=-1,93 ; p=, 053$ ). Geconcludeerd kan worden dat de astmapopulatie meer winst had op het aantal ziekenhuisdagen dan de COPD-populatie.

Tabel 6.15. Chi-kwadraatanalyse van aantallen patiènten; geslacht, diagnose en burgerlijke staat met betrekking tot twee behandelresultatenniveaus van de frequentic van het aantal ziekenhuisdagen ( $\mathrm{N}=93$ )

\begin{tabular}{|c|c|c|c|c|c|}
\hline & \multicolumn{2}{|c|}{$\begin{array}{l}\text { verbeterd } \\
N=46\end{array}$} & \multicolumn{2}{|c|}{$\begin{array}{l}\text { onveranderd/ } \\
\text { verslechterd } \\
N=47\end{array}$} & \multirow[b]{2}{*}{$x^{2}$} \\
\hline & $N$ & \% & $N$ & क & \\
\hline geslacht $(N=93)$ & & & & & 91 \\
\hline $\operatorname{man}(N=41)$ & 18 & 44 & 23 & 56 & \\
\hline vrouw $(N=52)$ & 28 & 54 & 24 & 46 & \\
\hline diagnose $(N=93)$ & & & & & $3.21^{\prime}$ \\
\hline astma $(N=21)$ & 14 & 67 & 7 & 33 & \\
\hline $\operatorname{COPD}(N=72)$ & 32 & 44 & 40 & 56 & \\
\hline burgerlijke staat $(N=91)$ & & & & & .47 \\
\hline samenwonend $(N=55)$ & 25 & 45 & 30 & 55 & \\
\hline alleenwonend $(N=36)$ & 19 & 53 & 17 & 47 & \\
\hline
\end{tabular}

'p<.10

Tabell 6.16. Multiple regressieanalyse op verschilscore van ziekenhuisdagen

\begin{tabular}{llll}
\hline & Multiple $R^{\prime}$ & $R^{2}$ & $\beta$ \\
\hline ziekenhuisdagen één jaar & & & \\
vór opname in het NAD & .34 & .12 & $-.28^{* *}$ \\
inadequatie & .40 & .16 & $-.28^{* *}$ \\
pakjaren & .54 & .29 & $.28^{* *}$ \\
\hline
\end{tabular}

$\cdots p<01$

Uit. correlatieanalyse met betrekking tot de onafhankelijke variabelen blijkt dat scores op de variabelen depressie en inadequatie positief met elkaar samenhingen (Pearson $r=.64 ; p<.001$ ). Uit multiple regressieanalyse, toegepast op het effect van het aantal ziekenhuisdagen, waarbij de variabelen ziekenhuisdagen (baselinescore), leeftijd, pakjaren, depressie en inadequatie stapsgewijs werden ingevoerd, bleken de beginmeting (aantal ziekenhuisdagen gedurende het jaar vó́r opname in het NAD), de inadequatie en het aantal pakjaren het al dan niet verbeterd zijn qua ziekenhuisdagen te verklaren (zie tabel 6.16.). Veel ziekenhuisdagen voorafgaand aan opname in het NAD, alsmede een ongunstige inadequatiescore en weinig hebben gerookt blijken 
binnen de onderzoeksgroep een voorspellende waarde te hebben met betrekking tot een verbetering qua aantal ziekenhuisdagen.

\subsubsection{Determinanten van verslechtering van het aantal ziekenhuisdagen}

Met betrekking tot veranderingen in het aantal dagen dat in een ziekenhuis moest worden doorgebracht werd vervolgens onderzocht of een verslechtering op het aantal ziekenhuisdagen kon worden voorspeld uit scores op variabelen die bij opname waren bepaald. Het bleek dat een verslechtering alleen kon worden voorspeld uit het aantal ziekenhuisdagen in het jaar voorafgaand aan opname. De groep patiënten die was verslechterd had minder dagen in een ziekenhuis doorgebracht dan de groep patiënten die niet was verslechterd $(F=17.27 ; p<.001)$.

\subsubsection{Determinanten van verbetering van de mate van oraal corticosteroïgebruik}

De tabellen 6.17. en 6.18. geven inzicht in de scores op de onafhankelijke variabelen met betrekking tot veranderingsscores op de afhankelijke variabele 'oraal corticosteroïdgebruik'. De baselinescore blijkt significant verschillende waarden te vertonen met betrekking tot de scorecategorieën van veranderingen in oraal corticosteroïdgebruik: de patiëntengroep die 12 maanden na ontslag uit het NAD minder corticosteroïden gebruikte dan bij opname, kreeg bij opname meer van deze medicatie voorgeschreven dan de groep die 12 maanden na ontslag een onveranderde hoeveelheid of meer kreeg voorgeschreven. Verder bleek het aantal pakjaren te verschillen. De qua orale corticosteroïden verbeterde groep had minder pakjaren dan de groep patiěnten die hierop niet verbeterde. Verder bleek de angst bij benauwdheid hoger onder patiënten uit de verbeterde groep dan uit de groep die niet verbeterde qua orale corticosteroïden. Voor wat betreft de onafhankelijke variabelen die een significant verschil vertoonden aangaande de beide effectcategoricën van de variabele orale corticosteroïden werden correlatiecoëfficiënten bepaald. Er bleek geen significant verband te bestaan tussen de omvang van het corticosteroidgebruik bij opname en het aantal pakjaren (Pearson $\mathrm{r}=-.10$ ), en corticosteroïdgebruik en de score op de variabele angst bij benauwdheid bij opname (Pearson $r=14$ ).

Uit multiple regressieanalyse bleek alleen de beginscore (omvang van oraal corticosterö̈dgebruik bij opname) de variantie te verklaren (Multiple $R=.28 ; R^{2}=.08 ; \beta=-.28 ; p<.05$ ). 
Tabel 6.17. Variantieanalyse van scores op onafhankelijke variabelen met betrekking tot veranderingsscores op omvang van het oraal corticosteroidgebruik $(\mathrm{N}=71)$

\begin{tabular}{|c|c|c|c|c|c|}
\hline \multirow[b]{2}{*}{ SCORE BU OPNAME } & \multicolumn{2}{|c|}{$\begin{array}{l}\text { verbetend } \\
N=25\end{array}$} & \multicolumn{3}{|c|}{$\begin{array}{l}\text { onveranderd/verslechterd } \\
N=46\end{array}$} \\
\hline & $M$ & (SD) N & M & (SD) $\mathrm{N}$ & F-ratio \\
\hline \multicolumn{6}{|l|}{ oraal corticosteroildgebruik } \\
\hline bij opname $(N=71)$ & 3,3 & $(1.7) 25$ & 1.9 & $(2,3) 46$ & $7,55^{2 *}$ \\
\hline leeftijd $(N=71)$ & 49,7 & $(12,9) 25$ & $53,3($ & $(12,7) 46$ & 1.31 \\
\hline duur aandoening $(N=61)$ & 16.5 & $(14,1) 23$ & $19,3($ & $(17,1) 38$ & .43 \\
\hline FEV, \& norm $(N=65)$ & 62.6 & $(31,3) 21$ & 61,21 & $(25,4) 42$ & .04 \\
\hline kortademigheid $(N=64)$ & 63.0 & $(20,3) 22$ & 66,31 & $(17.9) 42$ & .46 \\
\hline pakjaren $(N=70)$ & 8,21 & $(13,0) 25$ & 14,21 & $(16,7) 45$ & $2.83^{\prime}$ \\
\hline \multicolumn{6}{|l|}{ ervaren beperkingen } \\
\hline dagelijkse activiteiten $(N=71)$ & 6.4 & $(2,0) 25$ & 6.1 & $(2,0) 46$ & .25 \\
\hline angst bij benauwdheid $(\mathrm{N}=69)$ & 28.9 & $(1.8) 24$ & 25,4 & $(7,6) 45$ & $3.22^{\prime}$ \\
\hline schaamte $(N=71)$ & 16,8 & $(6,5) 25$ & 17.1 & $(7,3) 46$ & .21 \\
\hline angst (SCL-90) $(\mathrm{N}=71)$ & 20.5 & $(6,4) 25$ & 18.9 & $(7,0) 46$ & 92 \\
\hline depressie (SCL-90) $(N=71)$ & 30.1 & $(8.7) 25$ & 28,8 & $(10,5) 46$ & .29 \\
\hline inadequatie (NPV) $(\mathrm{N}=71)$ & 17,8 & $(9,0) 25$ & 15.9 & $(9,4) 46$ & .69 \\
\hline sociale inadequatie (NPV) $(\mathrm{N}=71)$ & 11.7 & $(6,9) 25$ & 12.0 & $(7,5) 46$ & .02 \\
\hline zeifwaardering (NPV) $(\mathrm{N}=71)$ & 23,8 & (8.1) 25 & 25,6 & $(6,3) 46$ & 1.13 \\
\hline ervaren sociale steun $(N=66)$ & 50,0 & $(4,7) 25$ & 50.0 & (6.5) 41 & .04 \\
\hline kunnen praten over aandoening ( $N=66$ ) & 24,4 & (3.8) 25 & 24,6 & $(5,1) 41$ & .02 \\
\hline
\end{tabular}

${ }^{\prime} p<10, \cdots p<.001$

Tabel 6.18. Chi-kwadraatanalyse van aantallen patiènten: geslacht, diagnose en burgerlijke staat met betrekking tot twee behandelresultatenniveaus op aantallen oraal corticosteroidgebruik. $(N=71)$

\begin{tabular}{|c|c|c|c|c|c|}
\hline & \multicolumn{2}{|c|}{$\begin{array}{l}\text { verbeterd } \\
(N=25)\end{array}$} & \multicolumn{3}{|c|}{$\begin{array}{l}\text { onveranderd/ } \\
\text { verslechterd }(N=46)\end{array}$} \\
\hline & $N$ & $\%$ & $N$ & \% & $x^{2}$ \\
\hline geslacht $(N=71)$ & & & & & .26 \\
\hline $\operatorname{man}\left(N^{\prime}=34\right)$ & 13 & 52 & 21 & 48 & \\
\hline vrouw $(N=37)$ & 12 & 46 & 28 & 54 & \\
\hline diagnose $(N=7 !)$ & & & & & .07 \\
\hline $\operatorname{astma}(N=13)$ & 5 & 39 & 8 & 61 & \\
\hline COPD $(N=58)$ & 20 & 35. & 38 & 65 & \\
\hline burgerlijke staat $(N=69)$ & & & & & .03 \\
\hline samenwonend $(N=48)$ & 17 & 35. & 31 & 65 & \\
\hline alleenwonend $(N=21)$ & 7 & 33 & 14 & 67 & \\
\hline
\end{tabular}

\subsubsection{Determinanten van verslechtering van de mate van oraal corticosteroïdgebriaik}

Er werd tevens onderzocht welke variabelen, gemeten bij opname, een verslechtering van het gebruik van orale corticosteroïden konden voorspellen. Uit de analyses kwam naar voren dat alleen de omvang van het gebruik van deze medicatie bij opname een voorspellende betekenis had. Patiënten die verslechterden hadden minder orale corticosteroïden dan de groep patiënten die onveranderd bleef en verbeterden op deze variabele $(F=4.02 ; p<.05)$. 


\subsection{Veranderingen in psychologische en longfunctiekenmerken als determinanten van effecten op ervaren beperkingen en op aspecten van medische consumptie}

In de tabellen 6.19. en 6.20 worden de resultaten weergegeven van variantieanalyse van scores op de onafhankelijke variabelen (het al dan niet verbeterd zijn qua psychologische variabelen en longfunctie) met betrekking tot verschilscores op ervaren beperkingen in dagelijkse activiteiten, oraal corticosteroïdgebruik, ziekenhuisopnamen en aantal dagen dat in een ziekenhuis werd doorgebracht (de vijfde onderzoeksvraag).

Uit tabel 6.19. blijkt dat het al dan niet verbeterd zijn op schaamte en op angst bij benauwdheid samenhing met de verschilscore op ervaren beperkingen in dagelijkse activiteiten. Bij multiple regressieanalyse bleken beide variabelen niet in het model te zijn opgenomen, wat betekent dat de scores op deze variabelen de variantie niet konden verklaren.

Inzake de afhankelijke variabele 'orale corticosteroïden' blijkt dat de gemiddelde verschilscore op deze variabele verschillende waarden vertoont met betrekking tot het al dan niet verbeterd zijn op angst. Uit multiple regressieanalyse blijkt ook dat de variantie met betrekking tot de verschilscores van het oraal corticosteroïdgebruik niet kon worden verklaard uit het al dan niet verbeterd zijn van de psychologsiche en longfunctiekenmerken.

Tabel 6.19. Variantieanalyse van verschilscores op de afhankelijke variabelen ervaren beperkingen dagelijkse activiteiten en orale corticosteroïden met betrekking tot al dan niet verbeterd zijn op een aantal psychologische en longfunctiekenmerken

verschilscore op
ervaren beperkingen orale corticosteroiden

$M$ (SD) $N$ Fratio $\quad M \quad(S D) N \quad$ F-ratio

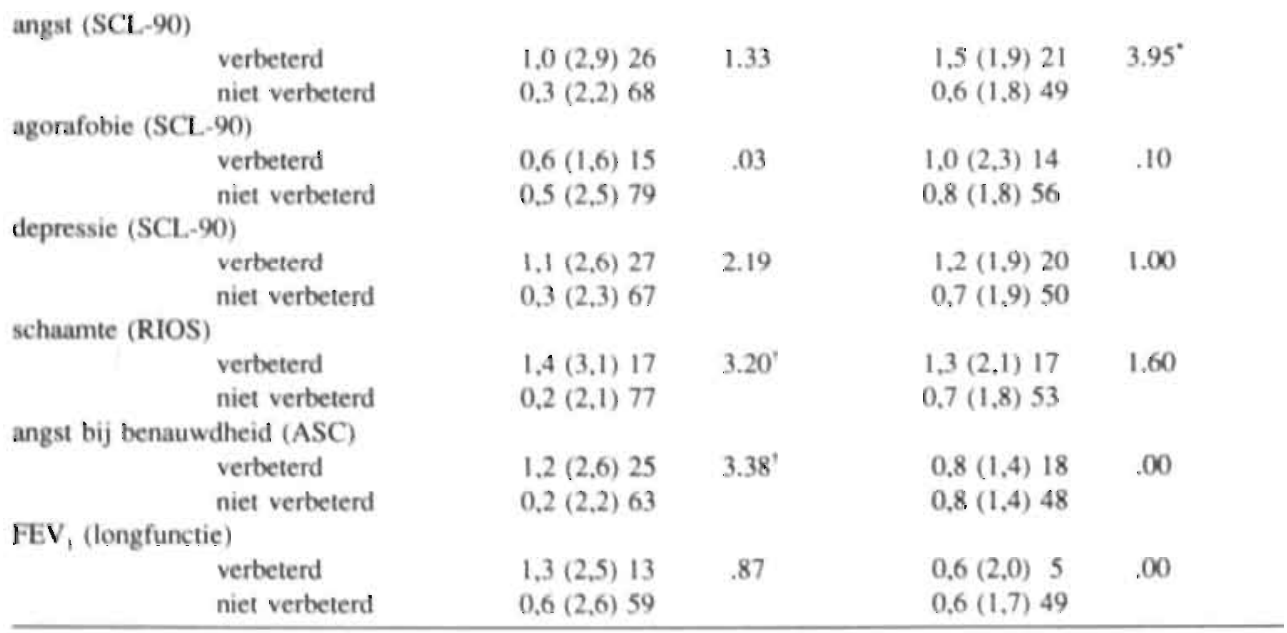

${ }^{t} p<.10 ;{ }^{*} p<.05$

Tabel 6.20. foont het resultaat van deze variantieanalyses aangaande de afhankelijke variabelen 'frequentie yan ziekenhuisopnamen' en 'frequentie van ziekenhuisdagen'. Hieruit blijkt dat met betrekking tot de verschilscores op het aantal ziekenhuisopnamen deze variabele samenhing met het verbeterd zijn op angst, op agorafobie en op depressie. Multiple regressieanalyse leidde 
tot de conclusie dat depressie de belangrijkste voorspellende variabele is $\left(R=.43 ; R^{\prime}=.19 ; \beta=.43\right.$; $p<.01)$.

De verschilscore van de frequentie van ziekenhuisdagen bleek samen te hangen met het al dan niet verbeterd zijn op angst en depressie, waarbij eveneens uiteindelijk alleen de depressie de variantie kon verklaren $\left(R=.29 ; R^{2}=.08 ; \beta=-.29 ; p<.05\right)$.

Een verbetering op de FEV, bleek geen van de verschilscores van de afhankelijke variabelen te kunnen voorspellen.

Tabel 6.20. Univariate variantieanalyse van verschilscores op de afhankelijke variabelen ziekenhuisopnamen en ziekenhuisdagen met het al dan niet verbeterd zijn op een aantal psychologische variabelen als onafhankelijke variabelen

\begin{tabular}{|c|c|c|c|c|}
\hline & \multicolumn{4}{|c|}{ verschilscore op } \\
\hline & \multicolumn{2}{|c|}{ ziekenhuisopnamen } & \multicolumn{2}{|l|}{ ziekenhuisdagen } \\
\hline & $M$ (SD) $N$ & F-ratio & $M \quad(S D) N$ & F-natio \\
\hline \multicolumn{5}{|l|}{ angst (SCL-90) } \\
\hline verbeterd & $1,5(2,3), 15$ & $4.26^{\circ}$ & $24,6(30,8) 16$ & $2.96 !$ \\
\hline niet verbeterd & $0.2(1,9) 35$ & & $3,5(45,4) 45$ & \\
\hline \multicolumn{5}{|l|}{ agorafobie (SCl-90) } \\
\hline verbeterd & $1.7(2.9) 9$ & $3.18^{\prime}$ & $22,7(41.3) 12$ & 1.52 \\
\hline niet verbeterd & $0,3(1,8) 41$ & & $5,7(43.0) 49$ & \\
\hline \multicolumn{5}{|l|}{ depressie (SCL-90) } \\
\hline verbeterd & $1.9(1,9) \quad 15$ & $11.03^{\mathrm{mm}}$ & $28,8(25,7) 17$ & $5.39^{*}$ \\
\hline niet verbeterd & $0,0(1,9) 35$ & & $1.4(45,9) 44$ & \\
\hline \multicolumn{5}{|l|}{ schaamte (RIOS) } \\
\hline verbeterd & $0,8(1,8) \quad 10$ & .20 & $16,9(18,8), 13$ & .58 \\
\hline niet verbeterd & $0,5(2.2) 39$ & & $6.6(47.7) 47$ & \\
\hline \multicolumn{5}{|l|}{ angst bij benauwdheid (ASC) } \\
\hline verbeterd & $0.6(1.7) \quad 14$ & .00 & $17,0(34,0) 16$ & .63 \\
\hline niet verbeterd & $0.6(2,3) 33$ & & $6.7(47.2) 41$ & \\
\hline \multicolumn{5}{|l|}{$\mathrm{FEV}_{\text {! (longfunctie) }}$} \\
\hline verbeterd & $0,3(2,2) \quad 12$ & .20 & $21,1(68,2), 14$ & .15 \\
\hline niet verbeterd & $0.7(2,2) 41$ & & $15.2(45,4) 55$ & \\
\hline
\end{tabular}

'p<.10;" $p<.05 ;{ }^{* *} p<001$

\subsection{Samenvatting}

In dit hoofdstuk werden mogelijke determinanten van effecten van een verblijf in het NAD bestudeerd. Als effectvariabelen werd gekozen voor de ervaren beperkingen in dagelijkse activiteiten en voor de aspecten van medische consumptie.

Allereerst werd bekeken of het al dan niet verbeterd of verslechterd zijn op deze afhankelijke variabelen kon worden voorspeld uit de scores op enkele variabelen, gemeten bij opname. Vervolgens werd bekeken of veranderingen op psychologische en longfunctiekenmerken samenhingen met de verschilscore op genoemde effectvariabelen.

Inzake de ervaren beperkingen in dagelijkse activiteiten is gebleken dat de patiêntengroep die op dit kenmerk verbeterde, bij opname gunstiger scoorde op de variabele die schaamte meet dan de groep die niet verbeterde. Bovendien bleek dat patiënten die verbeterden op ervaren beperkingen in dagelijkse activiteiten hierop bij opname een ongunstiger baselinescore hadden dan patiënten die niet verbeterden qua ervaren beperkingen. 
Verder bleek dat een verandering van ervaren beperkingen in dagelijkse activiteiten niet voldoende samenhang vertoonde met een verbetering op de psychologische en longfunctiekenmerken om te kunnen spreken van een voorspellende waarde van deze kenmerken voor een verandering van het kenmerk ervaren beperkingen.

Op de variabele die veranderingen qua huisartsbezoeken weergeeft bleek dat alleen de aanvangsmeting significant verschillende waarden vertoonde. Patiënten die in de periode van 12 maanden na ontslag uit het NAD minder huisartsbezoeken hadden bleken in het jaar voorafgaand aan opname in het NAD meer bezoeken te hebben gehad dan de groep van patiënten die even veel of meer bezoeken hadden. Omgekeerd bestaat er de samenhang van meer bezoeken vóor opname bij de groep van patiènten die minder bezoeken hadden na ontslag.

Het bovenstaande geldt eveneens voor de veranderingen in het aantal specialisthezoeken. Echter, daarbij geldt voor de groep die na ontslag méér specialistbezoeken had dan vóór opname, deze bij opname minder angst bij benauwdheid had dan de groep die even veel of minder specialistbezoeken had.

Met betrekking tot de verschillen qua aantal ziekenhuisopnamen en qua aantal ziekenhuisdagen treedı hetzelfde op als bij de overige afhankelijke variabelen. Patiënten die waren verbeterd op deze variabelen hadden respectievelijk meer ziekenhuisopnamen en meer ziekenhuisdagen in de periode van één jaar vó́r opname in het NAD, terwijl voor de patiëntengroep die was veslechterd op deze variabelen het omgekeerde gold.

Verder blijkt dat patiënten die verbeterden qua aantal ziekenhuisopnamen minder hadden gerookt dan patiënten die niet verbeterden. Ook blijkt dat de groep die minder ziekenhuisdagen had bij opname ongunstiger scoorde op de variabele die inadequatie meet.

De verschilscores qua aantal ziekenhuisopnamen en qua aantal dagen dat in een ziekenhuis moest worden doorgebracht bleek te kunnen worden voorspeld uit het al dan niet verbeterd zijn op het kenmerk depressie. Patiënten die waren verbeterd qua depressie hadden meer profijt aangaande het aantal ziekenhuisopnamen en het aantal ziekenhuisdagen.

Met betrekking tol de verbetering qua orale corticosteroïden gold eveneens dat de verbeterde groep bij opname meer tabletten kreeg voorgeschreven dan de groep die niet verbeterde. Een verbetering van orale corticosteroiden kon niet worden voorspeld uit veranderingen van psychologische en longfunctiekenmerken. 
In dit hoofdstuk zullen de bevindingen uit het onderzoek aan een nadere beschouwing worden onderworpen. Dit geschiedt voor de verschillende vraagstellingen afzonderlijk. Allereerst zullen de kenmerken van de onderzoekspopulatie zoveel mogelijk tegen het licht van bevindingen uit andere studies worden bekeken (7.1.). Vervolgens worden de resultaten aangaande het onderzoeksdeel betreffende het beloop van de kenmerken $(7.2$.$) en naar determinanten van$ profijt van de behandeling (7.3.) worden besproken. In 7.4. zullen enkele opmerkingen worden gemaakt omtrent de gehanteerde methode en de gebruikte vragenlijsten. In 7.5. en 7.6. komen respectievelijk aanbevelingen voor verder onderzoek en voor de klinische praktijk aan de orde. Vooraf dient te worden opgemerkt dat de in dit proefschrift beschreven bevindingen zijn gebaseerd op de longrevaidatiebehandeling van het NAD zoals deze plaatsvond in het jaar 1989. Het is mogelijk dat onderdelen hiervan reeds zijn gewijzigd.

\subsection{Kenmerken van de patièntenpopulatie}

In hoofdstuk 4 werden de kenmerken van de onderzoekspopulatie met betrekking tot enkele longfunctieparameters, rookgewoonte, aspecten van medische consumptie en van kwaliteit van leven besproken. Over het algemeen kan uit de resultaten de conclusie worden getrokken dat de onderzoeksgroep er bij opname in meendere opzichten emstig aan toe was: de longfunctie was fors gestoord, het medicatiegebruik hoog, het zorggebruik in de vorm van artsbezoeken en ziekenhuisopnamen aanzienlijk en ten slotte, de kwaliteit van leven, uitgedrukt in functionele, psychologische en sociale kenmerken gering.

Qua longfunctie blijken vergelijkingen te kunnen worden gemaakt met populaties Cara-patiënten uit de eerste, tweede en derdelijn.

De 73 astma en COPD-patiënten die door Dekker (1993) werden bestudeerd waren afkomstig uit de huisartspraktijk. Zij hadden een gemiddelde FEV (\% van de norm) van $71 \pm 27$. Collette (1993) deed onderzoek onder astma-patiënten uit de eerste en de tweedelijn en trof FEV (\% van de norm)-waarden aan van $72 \pm 21$ (eerstelijn) en $76 \pm 23$ (tweedelijn). De voor longrevalidatie in aanmerking komende patiẻnten uit het onderzoek van Cox (1991) hadden een gemiddelde

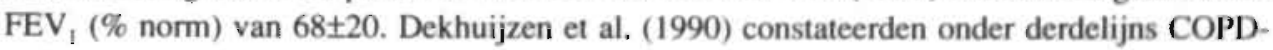
patiënten waarden van gemiddeld $45 \%$ van de norm. De COPD-patiënten die door Wijkstra et al. (1994) werden gezien en voor longrevalidatie aan huis in aanmerking kwamen, vertoonden een $\mathrm{FEV}_{1}$ (\% van de norm) van $44 \pm 11$. Tegen de achtergrond van bovenstaande gegevens $k$ an worden geconcludeerd dat de gemiddelde longfunctiewaarde die bij de astma- en COPD-populatie van de onderzoeksgroep werd aangetroffen $(F E V, \%$ van de norm $=61 \pm 25)$ de ernst van de aandoening van deze populatie tot uitdrukking brengt.

Met betrekking tot het medicijngebruik van de onderzoekspopulatie valt op dat $100 \%$ chronisch gebruiker is van één of meer middelen uit de Cara-geneesmiddelengroep. Een meerderheid $(89 \%)$ kreeg zelfs drie of meer middelen hieruit voorgeschreven. Bovendien was $64 \%$ van de patiënten aangewezen op orale corticosteroïden, met een gemiddeld gebruik van $15 \mathrm{mg}$ per dag, hetgeen, zeker in vergelijking met het gebruik van patiënten eerste- en tweedelijns-populaties aanzienlijk is. Immers, onder de populatie eerstelijns patiënten die door Dekker (1993) werd bestudeerd gebruikte $27 \%$ inhalatie corticosteroìden en was $5 \%$ afhankelijk van orale 
corticosteroïden. Uit de resultaten van de studie van Colette (1993), was 36\% van de eerstelijnspatiënten en $78 \%$ van de tweedelijns-patiënten aangewezen op inhalatie corticosteroïden. Geen van deze eerste en tweedelijns-patiënten bleek afhankelijk te zijn van orale corticosteroïden.

Helaas konden aangaande het aantal artsbezoeken in verband met Cara, geen vergelijkingen worden gemaakt met gegevens van andere populaties. De patiènten uit de onderzoeksgroep behoefden voor het grootste deel $(74 \%)$ zowel huisarts- als longspecialistconsulten.

Het aantal ziekenhuisopnamen en ziekenhuisdagen ten behoeve van het onder controle krijgen van de Cara-klachien is hoog te noemen. Helaas biedt de onderzoeksliteratuur ook hieromtrent geen vergelijkingsmateriaal.

Ook de kwaliteit van leven werd in kaart gebracht. Het is moeilijk om de resultaten te vergelijken met andere Cara-populaties, aangezien uit de onderzoeksliteratuur weinig consistentie blijkt omtrent het gebruik van meetinstrumenten om dit concept te meten. Tevens worden er verschillende definities van kwaliteit van leven gebruikt, terwijl bovendien onderscheid bestaat tussen de algemene en de ziekte-specifieke benaderingen van het begrip. Op het moment dat dit onderzoek van start ging waren meetinstrumenten om kwaliteit van leven bij somatisch zieken te meten nog onvoldoende ontwikkeld. Met betrekking tot Cara bestond alleen 'The Chronic Respiratory Questionnaire' (Guyatt et al. 1987a), waarvan de subschaal dyspnoe, ofwel 'ervaren kortademigheid' werd gebruikt. De overige in dit onderzoek gehanteerde meetinstrumenten, waarmee de verschillende aspecten van kwaliteit van leven in kaart werden gebracht, zijn elk ooit voor een ander doel geconstrueerd.

Het functionele aspect van kwaliteit van leven werd beschreven aan de hand van de lichamelijke beperkingen die de patiënt ondervind in het uitvoeren van dagelijkse activiteiten enerzijds, en de ervaren kortademigheid anderzijds. Ter illustratie: 16\% van de onderzochte populatie gaf aan vanwege de gezondheid het grootste gedeelte van de dag in bed of op een stoel door te moeten brengen; $57 \%$ rapporteerde door gezondheidsproblemen geen beroep of huishouden te kunnen uitoefenen; $97 \%$ voelde zich vanwege de gezondheid belemmerd in het uitvoeren van een inspannende lichamelijke activiteit, zoals een stukje hardlopen of zware voorwerpen tillen. In de literatuur werd geen enkele andere studie aangetroffen onder derdelijns Cara-patiënten, waarin dezelfde vragenlijst voor het meten van ervaren lichamelijke beperkingen werd gebruikt. Een vergelijking van de uitkomst op dit kenmerk bleek wèl mogelijk met eerste en met tweedelijnspopulaties (Colette, 1993; Kaptein et al., 1987d; Schrier et al., 1992). Uit die vergelijking kan worden geconcludeerd dat de onderzoeksgroep duidelijk meer belemmerd was qua dagelijkse activiteiten dan Cara-patiënten uit de eerste- en tweedelijns gezondheidszorg.

Het psychologische aspect van kwaliteit van leven werd in kaart gebracht door middel van een beschrijving van het psychologisch klachtenpatroon (SCL-90), persoonlijkheidskenmerken (NPV) en enkele ziekte-specifieke psychologische kenmerken (schaamte; angst bij benauwdheid). Voora! de algemene psychologische kenmerken (SCL-90 en NPV) vertoonden in vergelijking met verschillende andere populaties, een ongunstig beeld. Geheel volgens verwachting week de onderzoeksgroep in psychologische opzicht sterk af van 'niet-zieke' mensen. Echter, ook in vergelijking met patiênten met een andere (chronisch) somatisch ziekte bleek de onderzoeksgroep zich over het algemeen meer gespannen, angstig, depressief en labiel te voelen. Er bleek eveneens een vergelijking mogelijk op enkele psychologische kenmerken (inadequatie; zelfwaardering: 
schaamte) met de eerste- en tweedelijns-populatie van Colette (1993). Op de inadequatie en de zelfwaardering scoorde de onderzoeksgroep van het NAD ongunstiger, terwijl dat op het ziektespecifieke kenmerk 'schaamte' niet het geval was.

Wanneer een vergelijking wordt gemaakt met de tweedelijns-populatie die door Kaptein (1982) werd bestudeerd bleek de onderzoeksgroep van het NAD wèl ongunstiger te scoren op schaamte, echter niet op angst bij benauwdheid.

Op alle psychische klachten en persoonlijkheidskenmerken die door Dekhuijzen et al. (1990) werden gemeten onder derdelijns longrevalidatie-patiēnten scoorde de onderzoekspopulatie aanmerkelijk ongunstiger.

Uit bovenstaande vergelijkingen is af te leiden, dat de onderzoeksgroep uit het NAD vooral qua algemene psychologische kenmerken in ongunstige zin afweek van eerste-, tweede en derdelijns Cara-populaties. Vergelijkingen van de scores op de ziekte-specifieke psychologische kenmerken (schaamte; angst bij benauwdheid) bleken niet consistent in die richting wijzen.

Van het sociale aspect van kwaliteit van leven kon geen vergelijking worden gegeven met andere populaties. Dat maakt de inschatting van de emst op dit aspect van $\mathbf{k} w a$ aliteit van leven lastig. Echter, uit de antwoorden op itemniveau kan worden afgeleid dat veel van de patiěnten uit de onderzoeksgroep zich in een sociaal isolement bevinden en moeite hebben de problemen met betrekking tot de aandoening aan de orde te stellen bij mensen uit de directe omgeving.

\subsection{Het beloop van de kenmerken over de verschillende meetmomenten}

In hoofdstuk 5 werd allereerst het beloop geschetst van de gemiddelde scores op de aspecten van medische consumptie en kwaliteit van leven. De meeste van de gemiddelde scores bileken bij ontslag, bij 6 maanden en bij 12 maanden na ontsiag statistisch gunstige significante verschillen te vertonen ten opzichte van de gemiddelde scores bij opname. Tussen het moment van opname en het moment van ontslag bleek deze verandering het grootst. Over het algemeen bleek het beloop van de scores op de kenmerken die de medische consumptie en de kwaliteit van leven kwahiteit van leven uitdrukken gunstig.

Bij statistische toetsing van de verschillen tussen de scores van de medische consumptie gemeten over de periode van het jaar voor opname in het NAD en de periode van het jaar na ontslag bleken de veranderingen op alle gemeten aspecten statistisch significant te zijn. Zowel de artsconsulten als de ziekenhuisopnamen en het aantal dagen dat in een ziekenhuis moest worden doorgebracht, namen in frequentie af. Ook de omvang van het oraal corticisteroïdgebruik bleek 12 maanden na ontslag ten opzichte van het moment van opname te zijn gedaald, terwijl het gebruik van de inhalatievorm iets was toegenomen. Gezien het feit dat het veelvuldig gebruik van orale corticisterö̈den emstige bijverschijnselen kan geven en deze bij de inhalatievorm. achterwege blijven, kan hier gesproken worden van een gunstig resultaat.

Uitgaan van gemiddelden van de gehele onderzoeksgroep en van statistisch significante verschillen tussen deze gemiddelden op de verschillende meetmomenten levert echter nog geen informatie over aantallen patiënten die wel en die niet zijn veranderd op de verschillende kenmerken. Om dit vast te stellen werd op basis van de in hoofdstuk 3 beschreven procedure, de patiëntengroep ingedeeld in de categorieèn 'verbeterd' (of in geval van de artsbezoeken 'minder'), 'onveranderd', en 'verslechterd' (of in geval van de artsbezoeken 'meer'). Het percentage patiènten dat de arts minder bezocht en minder in een ziekenhuis werd opgenomen in het jaar na ontslag, in vergelijking met het jaar voor opname in het NAD lag tussen de 40 en $50 \%$. Onveranderd hierop 
bleek 20 tot $40 \%$ en meer medische consumptie had 20 tot $30 \%$ van de onderzoeksgroep. Voor het oraal corticosteroïdgebruik golden de percentages $35 \%$ minder, $55 \%$ onveranderd en $10 \%$ meer gebruik.

Het profijt voor de onderzoeksgroep van een opname in het NAD werd tevens uitgedrukt in een aantal aspecten van de kwaliteit van leven. Over het algemeen werd een beloop geconstateerd dat erop neerkomt dat de scores bij ontslag gunstiger waren dan bij opname terwijl gedurende de momenten 6 en 12 maanden na ontslag de scores iets ongunstiger waren dan bij ontslag maar nog steeds gunstiger dan bij opname. Bij vergelijking van de gemiddelde scores blijkt dat op het moment van 12 maanden na ontslag de volgende kenmerken in gunstige zin waren veranderd: ervaren beperkingen in dagelijkse activiteiten, ervaren kortademigheid, schaamte, inadequatie, sociale inadequatie, angst, agorafobie, depressie en kunnen praten over de aandoening. Uit de resultaten blijkt verder dat tijdens het moment van 12 maanden na ontslag in vergelijking met het moment van opname tussen 50 en $60 \%$ van de onderzoeksgroep op de aspecten van kwaliteit van leven onveranderd is gebleven, terwijl 9 tot $28 \%$ is verslechterd en tussen 17 tot $35 \%$ is verbeterd.

Bij de interpretatie van de gepresenteerde gegevens dient rekening te worden gehouden met de verschillen tussen degenen die wel en die niet respondeerden op de meetmomenten. Gebleken is dat patiënten die hun vragenlijsten niet terugstuurden, een ongunstiger score hadden op de variabele die het 'kunnen praten over de aandoening' meet. Ook bleken procentueel meer astmapatientien dan COPD-patiëriten niet te reageren op het moment van 12 maanden na ontslag. Voor de interpretatie van de uitkomsten aangaande de kenmerken op de verschillende meetmomenten heeft dit als consequentie dat de geconstateerde verschillen inzake de variabele 'kunnen praten over de aandoening' met enige voorzichtigheid moeten worden bekeken. Het. is mogelijk dat wanneer de groep van patiënten die deze vragenlijst niet heeft teruggestuurd dit alsnog zou doen, dit erin zou resulteren dat de uitkomst aangaande dit kenmerk wat minder gunstig zou zijn.

Met betrekking tot de diagnose moet er rekening mee worden gehouden dat de resultaten betreffende de kwaliteit van leven betrekking hadden op een onderzoeksgroep waarin $18 \%$ astma en $72 \%$ COPD heeft.

Naar aanleiding van het grote percentage patiënten dat op de aspecten van medische consumptie onveranderd is kan de vraag worden gesteld of dit al dan niet profijt uitdrukt. Het argument voor een bevestigend antwoord op deze vraag is dat hen een verslechtering bespaard is gebleven, hetgeen een vorm van preventie is. Echter, bij een patientengroep die er zo slecht aan toe is als de populatie die naar hel NAD werd verwezen is een stabie!-slechte toestand niet echt gunstig te noemen, tenzij het nòg slechuter kan, bijvoorbeeld wanneer de patiënt zonder opname zou zijn overleden.

Aangezien voorafgaand aan dit onderzoek geen duidelijk omschreven criteria waren vastgesteld waaraan de resultaten van dit evaluatieve onderzoeksdeel moesten voldoen, kan er hier geen uitspraak aver worden gedaan of deze voldoende geachi kunnen worden. In dit verband kan instemming wonden betuigd met wat door de Nationale Ziekenhuis Federatie in het projektverslag 'Kenmerken van het revalidatieproces' (Kobus et al., 1994) wordt opgemerkt omtrent het ontwikkelen van een instrument waarlangs de kwaliteit van zorg afgemeten kan worden. Hierin wordt gesteld dat instellingen dienen te worden uitgenodigd expliciet te worden over het produkt. 
of zo men wil de 'leveringsvoorwaarden' waar de door de instelling verleende zorg aan dient te voldoen.

\subsubsection{Enkele conclusies over de waarde van longrevalidatie in het NAD}

Uit de resultaten betreffende het beloop van de kenmerken over de verschillende meetmomenten kunnen een aantal conclusies worden getrokken met betrekking tot de waarde van longrevalidatie in het NAD:

- Longrevalidatie in het NAD leidt gemiddeld gesproken tot vermindering van de medische consumptie: artsconsulten, ziekenhuisopnamen en aantal dagen dat in een ziekenhuis moest worden doorgebracht nemen af. Dat geldt ook voor het orale corticosteroìdgebruik.

Uit analyses van aantallen patiěnten dat gemeten aan de medische consumptie in het jaar na ontslag wel en niet blijkt te hebben geprofiteerd van de revalidatie blijkt dat ongeveer $40 \%$ minder en rond $20 \%$ meer medische consumptie dan één jaar voor opname behoeft.

- Longrevalidatie in het NAD leidt gemiddeld gesproken tot een verbetering van de kwaliteit van leven van de patiënten. Analyse het aantal patiënten dat wel en dat niet blijkt te profiteren qua kwaliteit van leven wijst uit dat rond $30 \%$ van de patiénten verbetert, terwijl eveneens ongeveer $20 \%$ van de patiënten één jaar na ontslag blijkt te zijn verslechterd ten opzichte van het moment van opname. De overige patiènten blijven onveranderd.

\subsection{Determinanten van effecten van longrevalidatie in het NAD}

De indelingen in groepen patiënten die 12 maanden na ontslag wel en niet bleken te zijn veranderd ten opzichte van het moment van opname vormclen de basis voor de beantwoording van én van de twee vraagstellingen met betrekking tot determinanten van effecten van een behandeling in het NAD. De uitkomstvariabelen voor dit onderzoeksdeel waren de aspecten van medische consumptie en de ervaren beperkingen in dagelijkse activiteiten.

Aan de hand van een vooraf vastgestelde set van mogelijke determinantvariabelen werd bekeken in hoeverre de opnamescores van deze variabelen verschilden met betrekking iot de veranderingscategorieën. Voor de huisarts- en specialistbezoeken werd de categorie-indeling van 'minder', 'gelijk' en 'meer' bezoeken aangehouđen. Met betrekking tot de overige variabeien, te weten de aantallen ziekenhuisopnamen en ziekenhuisdagen, de omvang van het orale corticosteroïdgebruik en de ervaren beperkingen in dagelijkse activiteiten, werd uitgegaan van de veranderingsscores 'verbeterd', 'onveranderd' en 'verslechterd'. Het onderscheid in scorelabels bestaat op grond van de gedachte dat er met betrekking tot veranderingen van artsbezoeken niet van wordt uitgegaan dat meer bezoeken een verbetering of een verslechtering inhoudt. Met betrekking tot de overige variabelen die aspecten van medische consumptie uitdrukken wordt in dit onderzoek wèl gesproken van een verbetering of een verslechtering van scores.

Voor de samenstelling van een set van mogelijke determinantvariabelen werd zowel gekozen uit variabelen uit de verschillende aspecten van kwaliteit van leven, als voor de longfunctie $\left(F E V_{1}\right)$, de duur van de aandoening, de leeftijd, het geslacht, de diagnose en de burgerlijke staat. Door middel van een aantal analysestappen (univariate analyse, correlatieanalyse en discriminantanalyse) werd nagegaan op welke kenmerken de patiënten die wel en niet verbeteren en die wel en niet verslechteren op de uitkomstvariabelen zich onderscheidden. 
Voor alle uitkomstvariabelen gold dat de baselinescore van die variabele in hoge mate het al dan niet verbeteren en al dan niet verslechteren ervan voorspelde. Patiënten die verbeterden qua medische consumptie en qua ervaren beperkingen onderscheidden zich van patiënten die niet verbeterden doordat zij bij opname een ongunstiger score hadden op de betreffende variabele. Omgekeerd geld $t$ dat patiënten die op deze variabelen verslechterden zich van patiënten die niet verslechterden onderscheidden door een gunstiger baselinescore op deze variabele. Anders gezegd: patiënten die profiteerden van een behandeling in het NAD in termen van medische consumptie en ervaren beperkingen in dagelijkse activiteiten waren er bij opname wat deze kenmerken aangaat siechter aan toe dan degenen die niet bleken te profiteren van opname.

Aangaande de ervaren beperkingen in dagelijkse activiteiten bleek verder, dat de mate waarin de patiënt zich schaamde voor de aandoening een predictor was voor het al dan niet verbeteren op deze uitkomstvariabele. De patiënten die qua ervaren beperkingen in dagelijkse activiteiten bleken te zijn verbeterd vertoonden bij opname minder schaamte omtrent de aandoening, dan degenen die op dit kenmerk niet waren verbeterd. De variabele schaamte drukt de mate uit waarin de patiènt zich onderscheiden voelt van anderen, voomamelijk niet-zieke mensen. Schaamte betekent dat er last wordt ondervonden van dit ervaren onderscheid. Dit kenmerk kan het ziektegedrag van de patiènt in belangrijke mate beïnvloeden. Gedacht kan worden aan het uit de weg gaan van sociale activiteiten, waaruit sociaal isolement kan voortvloeien. Wanneer dit leidt tot vermijding van activiteiten in het algemeen, treedt mogelijk de dyspnoespiraal in werking, zoals beschreven in hoofdstuk één. Een toename van de ervaren beperkingen in dagelijkse activiteiten kan het gevolg zijn. Patiënten die zich minder of niet schamen lopen waarschijnlijk ook minder gevaar in deze dyspnoespiraal terecht te komen. Zij nemen vermoedelijk ook gemakkelijker hun medicatie in heı bijzijn van anderen in, hetgeen kan worden beschouwd als adequaat ziektegedrag hetgeen klachten kan voorkomen.

Wanneer werd bekeken op welke kenmerken de groep patiënten die verslechtert qua ervaren beperkingen in dagelijkse activiteiten zich onderscheidde van de groep patiënten die hierop niet verslechterde bleek de verslechterde groep ten tijde van opname minder goed in staat te zijn om over de aandoening met de directe omgeving te praten dan de groep patiënten die niet verslechterde qua ervaren beperkingen in dagelijkse activiteiten. Bovendien scoorden zij ongunstiger op 'inadequatie' dan degenen die niet verslechterden. Uit deze bevinding kan worden afgeleid dai zij die zich labiel, angstig en gespannen voelden (inadequatie) alsmede degenen die moeite hadden hun problemen omtrent de aandoening met de directe omgeving te bespreken, meer kans liepen qua ervaren beperkingen in dagelijkse activiteiten te verslechteren, dan zij die op deze kenmerken bij opname gunstiger scoorden. Deze bevinding is in overeenstemming met die van Agle et al. (1973) die tot de conclusie kwamen, dat patiënten die als gevolg van longrevalidatie verbeteren, bij aanvang van het longrevalidatieprogramma in minder ernstige mate psychopathologie vertonen, dan patiënten die de behandeling minder succesvol hadden afgerond. Een verklaring hiervoor kan zijn dat de genoemde psychologische problemen een negatieve invloed hebben op het ziektegedrag. Het minder in staat zijn te praten over de aandoening met mensen uit eigen omgeving kan tot sociaal isolement leiden, hetgeen op dezelfde wijze als beschreven in verband met schaamte, kan leiden tot een verslechtering qua ervaren beperkingen.

Met betrekking tot de verandering in de frequentie van huisartsbezoeken bleek geen andere dan de baselinescore een voorspellende waarde te hebben. Echter, de patiënten die gedurende 12 maanden na ontslag meer specialistbezoeken hadden dan tijdens het jaar voorafgaand aan opname in het NAD, hadden bovendien minder angst bij benauwdheid dan de groep patiènten 
die minder of even veel specialistbezoeken hadden. Een mogelijke verklaring voor dit verband is het feit dat patiènten met een geringe angst bij benauwdheid hun klachten minder goed waarnemen of geneigd zijn deze te negeren en daardoor niet adequaat op de benauwdheidsklachten kunnen reageren. Het gevolg kan zijn dat deze patiěnten vaker de specialist moeten raadplegen om de ontstane verergering van de lichamelijke toestand te herstellen. Dit is in overeenstemming met wat werd gevonden door onder andere Kaptein (1982).

Opmerkelijk is dat het in de literatuur beschreven verband tussen artsenbezoek en sociale steunkenmerken in dit onderzoek niet werd aangetroffen. Zo zou er een verband bestaan tussen de frequentie van het artsbezoek en de ervaren sociale steun uit de omgeving, al zijn de bevindingen hieromtrent niet consistent (Robert, 1988; Berkanovic et al, 1988). Het is mogelijk dat voor het vinden van dit verband allereerst een onderscheid moet worden gemaakt tussen een artsbezoek dat is geìnitieerd door de patiènt of door de arts. De gegevens die in dit onderzoek werden verzameld maken dit onderscheid helaas niet mogelijk.

De bevinding dat zij die verbeterden met betrekking tot de frequentie van de ziekenhuisopnamen en het aantal ziekenhuisdagen minder hebben gerookt dan degenen die niet verbeterden op dit belangrijke aspect van medische consumptie was volgens de verwachting. Geen onderscheid werd gemaakt tussen patiènten die reeds waren gestopt met roken, of tijdens de longrevalidatie hiermee stopten. Mogelijk dat zij die hiertoe in staat bleken meer profijt hadden dan zijn die bleven doorroken. Verder bleek dat patiënten die verbeterden qua aantal ziekenhuisdagen een ongunstiger score hadden op de variabele die inadequatie meet. Hiermee wordt aangegeven dat degenen die verbeteren zich meer gespannen, depressief en labiel voelden dan degenen die niet verbeterden met betrekking tot het aantal ziekenhuisdagen. Deze bevinding is niet in overeenstemming met de verwachting en de literatuur hieromtrent (Agle et al., 1973). Er ontbreeki een verklaring voor de discrepantie dat een hogere score op het kenmerk inadequatie een verbetering van het aantal ziekenhuisdagen en een verslechtering op het kenmerk ervaren beperkingen voorspelt.

Het al dan niet. verbeterd en verslechterd zijn qua corticosteroïdgebruik ten slotte, bleek uit geen andere dan de baselinescore te kunnen worden voorspeld.

In het tweede deel van hoofdstuk zes betreffende determinanten van effecten van longrevalidatie in het NAD, werden het al dan niet verbeterd zijn op de psychologische variabelen angst, depressie, agorafobie, schaamte en angst bij benauwdheid als onafhankelijke variabelen beschouwd. Als afhankelijke variabelen werden de continue verschilscores op de ervaren beperkingen in dagelijkse activiteiten en enkele aspecten van medische consumptie gekozen. Voor het vaststellen of een patiënt was verbeterd op deze (onafhankelijke) variabelen werd nu een andere methode gebruikı dan binnen de beantwoording van de tweede vraagstelling. Gebruik werd gemaakt van de 'Reliable Change Index' -formule van Jacobson et al. (1984). Reden voor het gebruik van deze methode voor het vaststellen van verandering op de genoemde variabelen was dat het hier gaat om veranderingen die verondersteld worden voor een belangrijk deel het resultaat te zijn van (gedrags)therapeutische interventies. Het was Jacobson et al. die met deze methode school maakten binnen psychotherapie-evaluatieonderzoek. Uit de naar aanleiding van deze methode vastgestelde percentages patiënten die wel en niet verbeterd waren op deze kenmerken bleek, dat deze methode van Jacobson iets strenger is dan de eveneens in dit proefschrift gebruikte methode van de categorie-indeling op basis van tertielen.

Uit de resultaten bleek dat verschilscores op ervaren beperkingen in dagelijkse activiteiten niet konden worden voorspeld uit het al dan niet verbeterd zijn op de psychologische en longfunctie- 
kenmerken. Hetzelfde geldt voor de verschilscores op oraal corticosteroïdgebruik. Een gunstiger verschilscore op het aantal ziekenhuisopnamen en het aantal ziekenhuisdagen kon worden voorspeld. door het al dan niet verbeterd zijn op depressie.

Opvallend en tevens in overeenstemming met andere onderzoeken is dat zowel de beginscore van de longfunctie alsmede een verbetering van de longfunctie geen relatie vertoont met de uitkomstvariabelen van het onderzoek en derhalve het resultaat van longrevalidatie niet kon voorspelien.

\subsection{Opmerkingen over de methode}

Een beperking van het onderzoek is het ontbreken van een controlegroep. Hierdoor is voorzichtigheid geboden bij het toeschrijven van de resultaten aan de longrevalidatie. Het blijkt moeilijk om dergelijk evaluatieonderzoek gecontroleerd uit te voeren. Hiertoe zouden patiënten die worden geïndiceerd voor longrevalidatie deze behandeling gedurende een periode worden onthouden, hetgeen als niet haalbaar werd beschouwd.

in de tweede plaats zijn enkele opmerkingen op zijn plaats omtrent het gebruikte meetinstrumentarium:

1. De kwaliteit van leven werd zowel met generieke als met ziekte-specifieke vragenlijsten in kaart gebracht. In vergelijking met bestaande vragenlijsten die de kwaliteit van leven op ziekte-specifiek niveau meten, worden in dit instrumentarium niet zozeer de specifieke Caraklachten gemeten. Alleen de subschaal 'ervaren kortademigheid' van de 'The Chronic Respiratory Disease Questionnaire' (Guyatt et al., 1987a), pretendeert in dit onderzoek een van deze klachten in kaart te hebben gebracht. Andere specifieke klachten van de onderzoekspopulatie werden elders beschreven (Speelberg et al., 1994).

De rationale achter de keuze van de in dit onderzoek gebruikte vragenlijsten als de SCL-90 en de NPV is dat daarmee tevens de ernst van de populatie in termen van psychische klachten in kaart kon worden gebracht. De Cara-specifieke vragenlijsten bieden daartoe veel minder gelegenheid.

2. Met betrekking tot de gemeten psychologische kenmerken dient verder te worden opgemerkt dat enkele hiervan een uitingsvorm künnen zijin van de longaandoening zelf. Ter illustratie daarvan dienen items wăarmee het (psychologische) symptoom 'somatische klachten' werd gemeten (SCL-90). Het antwoord op items als 'weinig puf (energie) hebben' en 'moeilijk adem kunnen krijgen' bepalen mede de score op deze subschaal. De handleiding van de SCL-90 geeft aan dat de schaal 'somatische klachten' in het algemeen een verzameling symptomen betreft die vaak worden gemeld bij functionele problemen. Een aantal van de in deze schaal geformuleerde symptomen, waaronder de hierboven genoemde, is echter veelal symptomen van Cara. Dit sluit echter niet geheel uit dat ze ook 'functioneel' zijn.

Een ander voorbeeld is het met de SCL-90 gemeten kenmerk 'depressie'. De symptomen die over hei algemeen kunnen worden opgevat als vitale kenmerken van een depressie, kunnen eveneens worden opgevat als symptomen van de longaandoening. Voorbeelden hiervan zijn vermoeidheid en slaapstoomissen. Anderszins is het mogelijk dat depressieve patiënten de emst van deze symptomen ernstiger inschatten dat niet-depressieve patiënten.

Enerzijds kunnen bovenstaande overwegingen pleiten voor de verdere ontwikkeling van een ziekte-specifieke kwaliteit-van-leven-vragenlijst voor Cara-patiënten, waartoe in Nederland al veel werk is verricht (Maillé et al., 1994). Anderzijds is het de vraag of met een ziekte-specifieke 
kwaliteit-van-leven-vragenlijst de gecompliceerde problematiek van Cara-patiènten zoals die naar het NAD worden verwezen afdoende in kaart kan worden gebracht.

3. In de inleiding (paragraaf 1.4.3.2.) wend, gesteund door de literatuur, opgemerkt, dat de kwaliteit van sociale steun een krachtiger voorspeller is voor gezondheid, dan structuur-maten, zoals het sociale netwerk. House et al. (1985) pleiten er daarom voor, om in gezondheidsstudies naar sociale steun voomamelijk gericht te zijn op de functionele inhoud van de relaties. De twee subschalen waarmee de sociale steun in dit onderzoek in kaart werd gebracht zijn schalen die op het functionele aspect van sociale steun zijn gericht. Eén daarvan was gericht op ervaren emotionele steun, de ander op de mogelijkheid met de omgeving te kunnen praten over de aandoening. De scores op eerstgenoemde subschaal vertoonden geen verbanden met de scores op de uitkomstvariabelen. Een reden kan zijn dat er met betrekking tot de invloed die uitgaat van sociale steun onderscheid zou moeten worden gemaakt tussen de invloed hiervan op fysieke gezondheid enerzijds en op het gebruik van medische zorg (uitkomstvariabele uit onderhavig onderzoek) anderzijds. Mogelijk dat de omvang van de medische consumptie niet zozeer verband houdt met de functionele sociale ondersteuning. maar dat juist de structuur-maten hierop van invloed zijn (zie ook: Pilisuk et al., 1987). Het verdient daarom aanbeveling in toekomstig onderzoek naar de relatie tussen sociale steun en medische consumptie eveneens dit structurele aspect van sociale ondersteuning in kaart te brengen. Patiènten die kunnen beschikken over een sociaal netwerk (structureel) doen wellicht minder snel een beroep op de arts dan patiènten met een beperkt netwerk. Een altematieve hypothese is dat deze patiēnten eerder een beroep doen op de arts, daartoe gestimuleerd door mensen uit de directe omgeving. Daarbij is het mogelijk tevens zinvol onderscheid te maken tussen de medische consumptie die door de patiènt wordt geinitieerd en die welke voortkomt uit het initiatief van de arts.

4. Een volgende opmerking betreft de vragenlijsten die in dit onderzoek het functionele aspect van kwaliteit van leven meten (de Dagelijkse Activiteiten Lijst en de Ervaren kortademigheidslijst). Het is mogelijk dat de vragen uit deze lijsten moeilijker zijn te beantwoorden door astmapatiënten, die aanvalsgewijs klachten vertonen, dan door patiënten met chronische bronchitis of longemfyseem, waarbij het klachtenpatroon eerder chronisch is.

5. Een laatste niet onbelangrijke opmerking aangaande de methode vloeit voort uit het feit dat er zich 12 maanden na ontslag een grote, zij het niet ongebruikelijke non-response voordoet (ongeveer $40 \%$ ). Hoewel de opname-kenmerken van de patiënten die 12 maanden na ontslag niet respondeerden in het algemeen niet verschilden van de patiënten die wel respondeerden kan door de uitval toch een vertekening van het resultaat zijn ontstaan. Dit hangt af van de redenen van non-respons. Oorzaken als verhuizing of desinteresse kunnen eventueel onschuldig zijn voor het resultaat. Wanneer echter patiënten die niet respondeerden daarvoor een reden hadden die wél samenhangt met de beschreven resultaten, zoals emstige insufficiëntie of overlijden, is er bij de beschrijving van de resultaten mogelijk toch sprake geweest van vertekening. Omdat binnen dit onderzoek geen extra inspanningen hebben plaatsgevonden om de redenen van de non-respons te achterhalen kan hieromtrent geen uitspraak worden gedaan.

\subsection{Implicaties voor vervolgonderzoek}

Uit de resultaten van dit onderzoek werd geconcludeerd dat de longrevalidatiebehandeling in het NAD voor de onderzoeksgroep over het algemeen heeft geleid tot gunstige resultaten qua 
medische consumptie en kwaliteit van leven. Zoals blijkt uit de beschrijving van longrevalidatie en de inhoud ervan in het NAD (hoofdstuk twee), betrof dit onderzoek de evaluatie van een groot bereik aan therapeutische interventies. Verondersteld wordt dat de kenmerken van het hooggebergte, de inspanningstraining, ademhalingsoefeningen, gezondheidsvoorlichting en opvoeding, psychosociale begeleiding, cognitieve gedragsmodificatie, enige maanden van huis zijn, etcetera, tezamen een bijdrage hebben geleverd aan het beschreven resultaat. De vraag blijft echter bestaan wat de relatieve bijdrage is van elk van deze onderdelen aan het bereiken van het eindresultaat. Het is van belang te weten voor welke patiënt welke vorm van longrevalidatie geschikt is. Om deze vraag te kunnen beantwoorden kan een onderzoeksopzet worden gekozen, waarin zowel gevarieerd wordt met patiëntkenmerken als met deelinterventies.

Een goed voorbeeld van onderzoek naar het relatieve belang van deelinterventies is dat van Atkins et al. (1984), die nagingen wat de effecten zijn van verschillende vormen van gedragstherapie op de therapietrouw van loopprogramma's voor patiënten met Cara. In het NAD zijn de laatsie jaren reeds enkele studies naar de effectiviteit van deelinterventies van start gegaan (Deenen et al., 1994).

Een andere belangrijke aanbeveling is om een kosten-baten-analyse bij de evaluatiestudie te betrekken. De belangrijkste vraag die daaraan ten grondslag ligt is of het bereikte effect de inspanning waard is geweest. Fishman (1994) stelt voor daarbij verschillende perspectieven te betrekken: die van de patiènt, die van de financier en die van de samenleving. Bovendien moeten zowel de kosten op korte als op lange termijn in ogenschouw worden genomen.

\subsection{Implicaties voor behandeling}

Bij patiênten met complexe Cara-problematiek, dient in de eerste plaats ruim aandachı te bestaan voor behandeling van psychologische en gedragfactoren die een blokkade of belemmering vormen voor het longrevalidatieproces en een gunstige uitkomst ervan in de weg kunnen staan. De resultaten uit dit onderzoek wijzen in dit verband in de richting van aandacht voor schaamte voor de aandoening, voor angst bij benauwdheid, voor depressie, rookgedrag, en kunnen praten over de aandoening met mensen uit de directe omgeving. Het is de taak van het behandelteam om, onder de coördinerende leiding van de psycholoog, deze belemmerende blokkades te helpen opruimen.

Schaamte is een beleving waarbij er sprake is van een zelfwaarneming alsof door de ogen van de ander gekeken wordt. Resultaat van deze zelf-evaluatie is de cognitie inferieur en belachelijk te zijn. Schaamte gaat in de beleving gepaard mett eenzaamheid, het gevoel er niet bij te horen. Ter vermijding van deze ervaring zal de patiënt in geval van schaamte veelal minder snel rekening houden met de eigen beperkingen en zich langer trachten aan te passen aan het tempo van de omgeving, terwijl ook de benodigde medicatie meestal niet wordt ingenomen in de aanwezigheid van anderen. Over het algemeen doet het gedrag van de patiënt die zich schaamt over de aandoening denken aan iemand die de aandoening ontkent, zonder dat dit het geval hoeft te zijn. Leren de schaamte te boven komen betekent echter leren rekening houden met de aandoening, ook in de aanwezigheid van anderen. Dit is een belangrijk behandeldoel, waarin de psycholoog een centrale rol kan spelen. Groepstherapie kan aangewezen zijn om de schaamte te doorbreken. Immers, de groeps-setting roept bij uitstek de schaamte op; het bekeken worden is onontkoombaar. Bovendien, het verwoorden van iets dat als schaamtevol ervaren wordt in het bijzijn van anderen, zonder dat afkeuring volgt, kan heilzaam zijn (Alonso et al., 1988). Dit kan zinvol gecombineerd worden met aangaande de longrevalidatie van toepassing zijnde redenen in groepen samen te komen, bijvoorbeeld het groepsgewijs aanbieden van gezondheidsvoorlichting en -opvoeding. 
In de tweede plaats is het van belang dat patiēnten met verwanten uit hun directe omgeving over de aandoening leren praten. De veel gehoorde klacht van patiēnten, dat ze de ander tot last zijn wanneer ze de gevolgen van hun aandoening aan hun omgeving voorleggen, kan eveneens leiden tot sociaal isolement en inadequaat ziektegedrag. Praten over de aandoening kan in de eerste plaats geleerd worden met de medepatiènten. In de meeste longrevalidatiecentra is juist hiervoor ruimschoots de gelegenheid. Door binnen de behandeling tevens aandacht te besteden aan leren kenbaar maken van de implicaties van de aandoening aan niet-Cara-patiénten treedt mogelijk een transfer op naar de thuisomgeving. Dit leerproces kan eventueel ondersteund worden door vrienden en gezinsleden bij de behandeling te betrekken.

De gunstige beìnvloeding van de angst bij benauwdheid vormt een derde uit dit onderzock voortvloeiend aandachtsgebied binnen de longrevalidatie. De angst leidt veelal tot vermijding van activiteiten en eventueel daaruit voorkomende toename van kortademigheidsklachten (Haas et al., 1993). Van de andere kant is uit dit onderzoek gebleken dat patiënten die gedurende het jaar na ontslag uit het NAD voor meer specialistbezoeken in aanmerking komen dan in het jaar voor opname in het NAD, een lager angstniveau bij benauwdheid hadden dan degenen die minder specialistbezoeken hadden. Hoewel het niet duidelijk is of een toename van specialistbezoeken een ongunstige of gunstige ontwikkeling betekent ligt toch voor de hand ervan uit te gaan dat voor een gunstig effect van longrevalidatie enigerlei mate van angst van belang is. Immers, angst kan een signaalwaarde hebben en de betrokkende erop wijzen dat actie moet worden ondemomen om de het gevaar (benauwdheid) de baas te worden. Het is de moeite waard te onderzoeken of GVO en selfmanagement een bijdrage hieraan zouden kunnen leveren.

Behandeling van depressie blijkt eveneens een succesvolle afloop van longrevalidatie te kunnen bevorderen. Daarom lijkt van belang de patiënt die bij aanvang van de opname verschijnselen van een depressie vertoont, hetgeen onder andere uit psychodiagnostisch onderzoek kan blijken, op tijd psychologische begeleiding te bieden.

In dit onderzoek werd een verband aangetroffen tussen de omvang van het rookgedrag binnen onbepaalde tijd voorafgaand aan opname in het NAD, en het succes van de longrevalidatie. Ten behoeve van de minderheid van de patiënten die in het NAD wordt opgenomen en (nog) rookt blijft een anti-rookprogramma geïndiceerd. Daarbij dient echter rekening te worden gehouden met het geringe succespercentage van dergelijke programma's (Dijkstra, 1995).

Het optreden van factoren die het longrevalidatieproces kunnen belemmeren doordat deze kunnen leiden tot een minder actieve inbreng van de patiènt wordt door behandelaars weleens 'gebrek aan motivatie' van de zijde van de patiênt genoemd. Het is vooral de taak van de psycholoog om te diagnostiseren of er sprake is van gedragingen en emoties (waaronder de schaamte en angst bij benauwdheid) die het aanleren van adequaat ziektegedrag in de weg staan. Vervolgens dienen interventies van het team erop te zijn gericht de patiënt te helpen deze blokkades te overwinnen. 


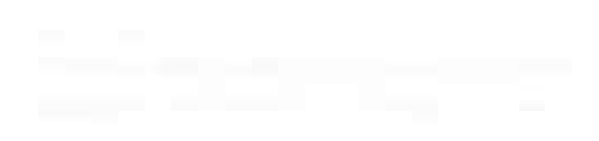


In dit proefschrift wordt verslag gedaan van gedragswetenschappelijk onderzoek onder patiënten met chronisch aspecifieke respiratoire aandoeningen (Cara) die in de periode van 1989 tot 1990 gedurende gemiddeld 3 maanden waren opgenomen in het NAD.

\section{In hoofdstuk 1 - 'CHRONISCHE ASPECIFIEKE RESPIRATOIRE AANDOENINGEN' -} worden verschillende aspecten met betrekking tot Cara besproken.

Allereerst wordt ingegaan op definities, waarbij zowel redenen om het begrip Cara te gebruiken alsook om juist het onderscheid tussen astma en COPD (chronic obstructive pulmonary disease) aan te brengen, worden aangegeven. De laatste jaren is vooral weer sprake van astma en COPD. De door de American Thoracic Society geformuleerde definities van astma en de onder COPD ressorterende aandoeningen chronische bronchitis en longemfyseem worden gepresenteerd. Vervolgens wordt ingegaan op het voorkomen van Cara, waarbij gebruik wordt gemaakt van onderzoeksgegevens uit binnen- en buitenland. Geconcludeerd kan worden dat Cara een veel voorkomend gezondheidsprobleem is. Het is te verwachten dat het voorkomen ervan in de komende jaren toeneemt.

In Nederland bestaan er ten behoeve van Cara verschillende behandelniveaus. Slechts een klein percentage patiênten heeft een dermate ernstige vorm van Cara, dat opname in een astmacentrum is aangewezen. De behandelvorm in deze derdelijnsvoorziening is multidisciplinair en wordt aangeduid met het begrip longrevalidatie. Binnen een aantal paragrafen worden vervolgens de psychologische en sociale aspecten van Cara besproken. De literatuur hieromtrent blijkt te kunnen worden geordend aan de hand van drie invalshoeken. De eerste is die welke psychologische en sociale kenmerken beschouwt als de aanleiding en zelfs als de oorzaak van het ontstaan van (symptomen) van Cara. Daaronder vallen de klassieke psychosomatiek, geinspireerd door de psychoanalytische theorie, en de leertheorie. Met betrekking tot de waarde van de cerstgenoemde stroming wordt in dit proefschrift aangesloten bij reeds eerder geformuleerde conclusies namelijk dat deze weinig bijdrage heeft kunnen leveren aan gezondheidswinst. Met betrekking tot de leertheoretische stroming geldt een soortgelijke conclusie als het gaat om de theorievorming aangaande de verklaring van het bestaan van Cara-symptomen. Wel blijkı de leertheorie enkele bruikbare gedragsinterventies te hebben voortgebracht die een bijdrage hebben kunnen leveren aan het beïnvloeden van het ziektegedrag.

De literatuur met betrekking tot psychologische en sociale gevolgen van Cara wordt besproken aan de hand van het concept kwaliteit van leven. Ook de door de World Health Organization in het leven geroepen begrippen stoornis, beperking en handicap passeren de revue. Er worden studies samengevat die een bijdrage leveren aan het in kaart brengen van gevolgen van Cara. De beschrijving van de gevolgen van de aandoening blijkt meestal te geschieden in termen van emotionele problematiek (depressie en angst) en op kleinere schaal aan de hand van het beschrijven van neuropsychologische tekorten en problemen op het gebied van de sexualiteit. Het laatste onderdeel in dit hoofdstuk beschrijft literatuur met betrekking tot psychologische en sociale kenmerken, opgevat als determinanten van het beloop van de aandoening. Theoretisch blijken concepten als 'psychomaintenance' en 'sociale steun' hiertoe handvatten te bieden.

In hoofdstuk 2 - 'LONGREVALIDATIE' - wordt nader ingegaan op de behandelvorm waarop het evaluatiedeel van het onderzoek zich richt, de longrevalidatie. 
Definitie, doelstelling en doelgroep van longrevalidatie in het algemeen en van die in het NAD. in het bijzonder, worden beschreven. Het blijkt dat de term longrevalidatie een containerbegrip is waaronder een veelvoud van interventies kunnen worden verstaan. Tezamen zijn deze interventies erop gericht te komen tot stabilisatie of zelfs verbetering van de longaandoening.

De revalidatie is een proces dat bij uitstek wordt begeleid door een multidisciplinair team en waarbij een actieve inbreng van de patiënt wordt verwacht. De afzonderlijke inbreng van de verschillende disciplines wordt kort beschreven, terwijl iets langer wordt stilgestaan bij de interventiemogelijkheden van de psycholoog. Belicht worden de mogelijkheden van de psychodiagnostiek en de cognitief gedragstherapeutische behandelmethoden, voorzover deze het resultaat van de longrevalidatie helpen bereiken. De longrevalidatie in het NAD kent nog een extra dimensie, die van het hooggebergte. De daar bestaande klimatologische omstandigheden brengen een. aantal gunstige voorwaarden voor longrevalidatie met zich mee.

Het hoofdstuk besluit met een paragraaf waarin literatuur aangaande effectonderzoek naar longrevalidatie wordt samengevat. Dit leidt tot de conclusie dat er veel verscheidenheid bestaat omtrent de in deze onderzoeken geëvalueerde behandelvormen. Tevens bestaat er tussen de verschillende studies veel onderscheid in de gebruikte afhankelijke variabelen waaruit het al dan niet succesvol zijn van de longrevalidatie moet blijken. Ten slotte blijken de toegepaste methoden verschillen te vertonen met betrekking tot het al dan niet gebruik maken van een controlegroep en van follow-up meetmomenten. Deze verschillen bemoeilijken de onderlinge vergelijkbaarheid van de studies.

In hoofdstuk 3 - VRAAGSTEL,LINGEN EN METHODE' - worden de vraagstellingen en de methode besproken. Het betreft vragen naar kenmerken van de onderzoeksgroep (longfunctie, rookgewoonte, medische consumptie en kwaliteit van leven), naar het beloop van kenmerken aangaande $k$ waliteit van leven en medische consumptie over de meetmomenten, en naar aantallen patiënten die gemeten aan deze kenmerken wel en niet blijken te profiteren van een opname in het NAD. Ten slotte is onderzoeksvraag wat determinanten zijn van het al dan geen profijt hebben van de opname in het NAD. De meetinstrumenten en de gehanteerde methode waaronder de statistische procedure komen in dit hoofdstuk aan bod.

\section{In hoofdstuk 4 - BESCHRIJVING VAN KENMERKEN VAN DE PATIËNTEN,} OPGENOMEN IN HET NAD' * wordt een antwoord gegeven op de eerste onderzoeksvraag. die naar kenmerken van de onderzoekspopulatie. Hiertoe worden enkele longfunctiekenmerken. rookgewoonte, medische consumptie en aspecten van kwaliteit van leven beschreven. De populatie die naar het NAD wordt verwezen blijkt er over het algemeen emstig aan toe te zijn. Dat blijkt zowel uit de longfunctiekenmerken als uit de kwaliteit van leven en de medische consumptie. Deze conclusie is mede gebaseerd op vergelijkingen met andere Cara-populaties uit de eerste-, tweede- en derdelijns gezondheidszorg. Het samengaan van emst op het vlak van somatiek, kwaliteit van leven en medische consumptie lijkı de indicatie voor opname in het NAD te vormen.

\section{In hoofdstuk 5 . VERGELIJKING VAN SCORES MET BETREKKING TOT} KENMERKEN VAN DE PATIËNTENPOPULATIE OVER DE VERSCHILLENDE MEETMOMENTEN' - wordt het beloop van de kenmerken over de meetmomenten opname, ontslag, 6 en 12 maanden na ontslag beschreven. Bovendien wordt de vraag beantwoord hoeveel patiènten op het moment van 12 maanden na ontslag, in vergelijking met het moment van opname op de aspecten van medische consumptie en kwaliteit van leven zijn verbeterd, zijn verslechterd of onveranderd zijn gebleven. Uit de resultaten blijkt, dat de gemiddelde scores op de meeste 
kenmerken 12 maanden na ontslag gunstiger zijn dan bij opname. De bepaling van aantallen en percentages wijst erop dat 12 maanden na ontslag ten opzicht van opname rond $25 \%$ van de patiënten blijkt te zijn verbeterd op de verschillende variabelen die kwaliteit van leven uitdrukken, rond $55 \%$ van de patiēnten is hierop onveranderd en $20 \%$ is verslechterd. Voor wat betreft de medische consumptie blijkt rond $42 \%$ minder, rond $37 \%$ even veel en rond $21 \%$ meer consumptie te behoeven.

In hoofdstuk 6 - DETERMINANTEN VAN EFFECTEN VAN LONGREYALIDATIE IN HET NAD' - worden mogelijke determinanten onderzocht van het al dan niet verbeterd zijn qua medische consumptie en kwaliteit van leven. Gekozen werd voor de uitkomstvariabelen ervaren beperkingen in dagelijkse activiteiten en medische consumptie. De baseline-score van deze variabelen blijken een belangrijke determinant voor een verbetering of verslechtering. De groep die verbeterde scoorde bij opname ongunstiger op de betreffende variabele dan de groep die niet verbeterde. Omgekeerd geldt dat de groep die verslechterde bij opname een gunstiger baselinescore had dan de groep die niet verslechterde. Aangaande de ervaren beperkingen blijken degenen die verbeterden op dat kenmerk, bij opname tevens minder schaamte omtrent hun aandoening te vertonen dan degenen die niet verbeterden. Voor wat betreft het aantal ziekenhuisopnamen en ziekenhuisdagen blijkt de groep die op deze kenmerken verbeterde minder te hebben gerookt. Voor het aantal ziekenhuisdagen geldt tevens dat diegenen die verbeterden ongunstiger scoorden op het persoonlijkheidskenmerk inadequatie.

De vraag naar het verband tussen veranderingen op psychologische kenmerken en longfunctie enerzijds en de verschilscores op ervaren beperkingen en ziekenhuisopnamen anderzijds leidt tot de conclusie dat veranderingen qua iongfunctie geen verbanden vertonen met deze uitkomstmaten, terwijl het verbeterd zijn qua depressie het effect van het aantal ziekenhuisopnamen en ziekenhuisdagen voorspelt.

In hoofdstuk 7 - 'DISCUSSIE' - worden allereerst de resultaten van het onderzoek aan een nadere beschouwing onderworpen en vergeleken met resultaten van andere studies.

Met betrekking tot de gehanteerde methode worden enkele kritische kanttekeningen geplaatst, betreffende het ontbreken van een controlegroep, het gebruikte meetinstrumentarium en de gekozen variabelen.

Voor vervolgonderzoek wordt de aanbeveling gedaan te gaan kijken naar de werkzaamheid van verschillende deelinterventies (bijvoorbeeld GVO) op langetermijn-effecten van de longrevalidatie. Tevens wordt de suggestie gedaan een kosten-batenanalyse in toekomstig onderzoek te betrekken. Tenslotte wordt de aanbeveling gedaan de psychologische interventies te richten op de gunstige beînvloeding van de schaamte voor de aandoening, de angst bij benauwdheid, de depressie en het rookgedrag. 

This thesis describes a behavioral scientific study regarding patients with chronic non-specific lung disease (CNSLD) who were admitted in the Dutch Asthma centre Davos in the period of 1989 till 1990. The treatment averaged three months duration.

\section{In chapter 1 - 'CHRONIC NONSPECIFIC LUNG DISEASE' - different aspects of CNSLD} are discussed.

Firstly, some definitions with respect to CNSLD are presented. Arguments are given for the use of the term CNSLD, and for the separate use of the terms asthma and Chronic Obstructive Pulmonary Disease (COPD). Over the last few years the individual terms asthma and COPD have been used more often than the term CNSLD. The definitions of asthma and the disorders included in COPD (chronic bronchitis and pulmonary emphysema) as given by the American Thoracic Society, have been given.

Secondly, the epidemiology of CNSLD is discussed. It may be concluded that CNSLD is a major health problem and an important cause of morbidity and mortality. It is to be expected that the prevalence of CNSLD will increase over the next 15 years. In the Netherlands, different levels of treatment exist with respect to CNSLD. The majority of patients are treated by general practitioners. Only a small proportion of the patients are recommended for treatment at an asthma centre. The treatment at such a centre is multi-disciplinary and is called pulmonary rehabilitation. Subsequently, psychological and social aspects of CNSLD are discussed. Material on these aspects may be collated on the basis of three view points. The first one considers the psychological and social characteristics as cause of the symptoms of CNSLD. This view is shared by the classical psychosomatic theory (inspired by psychoanalysis) as well as the learning theory. It may be concluded that both theories have contributed litile to the understanding of sypmtoms of CNSLD. However, learning theory has brought about some useful behavioral interventions, which have possitively contributed to affecting iliness behavior. The second point of view concerns the psychological and social consequences of CNSLD, discussed by means of the concept 'quality of life' and the World Health Organization-concepts 'disorder, impaiment and handicap'. Different studies have been summed up that have contributed to the discription of consequences of CNSLD. The discription of the consequences of the disorder generally takes place in terms of emotional problems (depression and anxiety) and also using the description of neuropsycholgical inadequacy and sexual problems.

The final part of the chapter describes literature with regard to psychological and social characteristics which are interpreted as being determinants of the course of the disorder. The concepts 'psychomaintenance' and 'social support' seem useful in theory.

The form of treatment concerned in the evaluation study is described in chapter 2 . 'PULMONARY REHABILITATION' - . Definitions, aims and target group of pulmonary rehabilitation in general, and that of the Dutch Asthma centre in particular, have been outlined. A diversity of interventions may be part of a pulmonary rehabilitation program. Together, these interventions focus on the stabilization, or the improvement of the lung disorder. Rehabilitation is a treatment process that is carried out primarily by multidisciplinary teams. The active participation of the patient is essential. In this chapter the contribution of the different disciplines are briefly described, whereas more attention is paid to the interventions of the psychologist. Also discussed are the importance and possibilities of psychodiagnostics and of cognitive behavioral 
therapy in helping to reach the rehabilitation aims. The pulmonary rehabilitation in the Dutch Asthma centre in Davos has an added advantage, namely that of high altitude, with some climatic circumstances, that offer favourable conditions for this type of treatment. The chapter ends with a paragraph which summerizes literature concerning effect studies on pulmonary rehabilitation. It may be concluded that there is a great variety with respect to the treatment forms under research. A lot of diversity also exists in the dependent variables used to express the effect of pulmonary rehabilitation. Finally, the applied methods of research exhibit differences regarding the use of a control group and of a follow-up measurement.

Chapter 3 - 'METHOD AND RESULTS' - describes the research questions and the methods that were used to answer these questions. There are three main research questions: 1. a question about characteristics of the study population (lung function, smoking behavior, medical consumption and quality of life), 2, a question about the course of the characteristics measured at different moments, and about the number of patients who, as far as these characteristics are concerned, take advantage of admission to the Dutch Asthma Centre Davos, and 3. the research question concerning determinants of benefits of an admission to the Dutch Asthma centre Davos. The measuring instruments and research method used, including the statistical procedure, are described in this chapter.

\section{In chapter 4 - DESCRIPTION OF CHARACTERISTICS OF THE PATIENTS, ADMITTED} TO THE DUTCH ASTHMA CENTRE DAVOS - an answer is given to the first research question, concerning characteristics of the population. Described are lung function characteristics, smoking habit, use of health care resources and the functional, psychological and social aspects of quality of life of the study population. It may be concluded that the popultation referred to the Dutch Asthma centre Davos appears to be seriously ill and that the illness is complicated by a decreased quality of life and high usage of medical resources. This conclusion is also based on a comparison with other CNSLD-populations from the primary, secondary and tertiary level of medical care. The combination of severity of somatic characteristics, quality of life and usage of medical resources seems to be reason for a reference to the Dutch Asthma centre Davos.

\section{In chapter 5 - 'COMPARISON OF SCORES OF CHARACTERISTICS OF THE PATIENT} POPULATION THROUGHOUT 'THE DIFFERENT POINTS OF MEASUREMENT' the course of the characteristics over the moment at the point of admission, discharge, and 6 and 12 months after discharge have been described. In addition, the question of how many patients 12 months after discharge are improved, deteriorated or unchanged on the jifferent variables in comparison with the moment of admission, is also discussed.

The results show that 12 months after discharge the scores on most characteristics are more favourable than at the point of admission. The assessment of amounts and percentages of patients show that 12 months after discharge about $25 \%$ appear to have improved, about $50 \%$ of the patients remained unchanged and $20 \%$ deteriorated on the different aspects of quality of life: As far as the usage of medical resources is concerned it appears that, in comparison with the moment of admission, about $42 \%$ used less resources, about $37 \%$ remained unchanged, and about $21 \%$ used more health care resources. 
In chapter 6 - DETERMINANTS OF EFFECTS OF PULMONARY REHABILITATION

IN THE DUTCH ASTHMA CENTRE DA VOS - determinants of improvement on use of medical resources and quality of life were investigated. The variables 'experienced limitations in daily activities' and use of medical resources formed the group of dependent variables. The baseline score of these variables appears to be an important predictor of improvement or deterioration on the dependent variables mentioned. The group of patients that improved scored less favourable at the moment of admission than the group of patients that didn $t$ improve. Likewise it appeared, that the group that deteriorated had a more favourable baseline score than the group that didn't deteriorate. Conceming the limitations in daily activities experienced, it appeared that the patients who showed an improvement on that characteristic, also expressed less shame about the disorder than the patients who exhibited no improvement.

The amount of days spent in care also accounts for the fact that the patients who improved had a less favourable score on the trait of 'inadequacy'. The research question conceming the connection between changes in psychological characteristics and lung function parameters on the one hand and the difference score on experienced limitations in daily activities and hospital admissions on the other, leads to the conclusion that changes in lung function show no connection with these outcome variables, whereas the improvement on depression scores predicts the effect scores on the amount of hospital admissions and days.

In chapter 7 - DISCUSSION - the results of the study have been discussed and compared with the results of other studies. With respect to the method used, some critical remarks have been made concerning the absence of a control group, and about the measuring instruments used and variables choosen. For subsequent studies it is recommended that a study be carried out into the effectiveness of the different interventions (e.g. patient education) on the long term over all effect of pulmonary rehabilitation. Furthermore it may be suggested to include a costbenefit analysis in futher studies.

Finally, it may be recommended to focus psychological interventions on affecting shame for the disorder, anxiety for dyspnea, depression and smoking behavior. 



\section{LTERATUUR}

Agle, D.P., Baum, G.L., Chester, E.H. \& Wendt, M. (1973). Multidiscipline treatment of chronic pulmonary insufficiency. I. Psychological aspects of rehabilitation. Psychasomatic Medicine, 35, 41-49.

Agle, D.P. \& Baum, G.L. (1977). Psychological aspects of chronic obstructive pulmonary discase. Medical Clinics of North America, 6I, 749-758.

Alexander, F., French, T.M., \& Pollock, G.H. (1968). Psychosomatic specificiry: experimental studly and results. Chicago: University of Chicago Press.

Alonso, A. \& Rutan, J.S. (1988). The experience of shame and the restoration of self respect in group therapy. International Journal of Group Psychotherapy, 38, 3-14.

American Thoracic Society. (1987). Standards for the diagnosis and care of patients with chronic obstructive pulmonary disease (COPD) and asthma American Review of Respiratory Disease, 136. 225-243.

Anderson, H.R., Bailey, P.A., Cooper, J.S., Palmer, J.C. \& West, S. (1983). Medical care of asthma and wheering illness in children: A community survey. Journal of Epidemiology \& Community Health, 37, 180186.

Appeis, A., Otten, F., Sturmans, F. \& Mulder, P. (1988). De KRIS follow-up studie II. Burgerijike staat en sterftekans. Tijdschrift voor Sociale Gezondheidszorg, 06, 67-69.

Arrindell, W.A. \& Entema, J.H.M. (1986). SCL.90, Handleiding by een multidimensionele psychopathologieindicator. Lisse: Swets \& Zeitlinger.

Atkins, C.., Kaplan, R.M. Timms, R., Reinsch, S. \& Lofback, K. (1984), Behavioral programs for exercise compliance in chronic obstructive pulmonary discase. Journal of Consulting and Clinical Psychology, 52. 591-603.

Barrera, M., Sandler, L. \& Ramsey, T. (1981). Preliminary development of a scale of social support: studies on college students. American Journal of Community Psychology, 9, 435-441.

Bandura, A. (1977), Self-efficacy: toward a unifying theory of behavional change. Psychological Review, 84. 191-215.

Beck. A.T. \& Emery, G. (1985). Anxiety disorders and phobias. A cognitive perspective. New York: Basic Books.

Bergner, M. (1989). Quality of life, health status and clinical research. Medical Care, 27, s148-s156.

Berkanovic, E. Hurwicz, M. \& Lansverk, J. (1988). Psychological distress and the decision to seek medical care. Social Science and Medicine, 27, 1215-1221.

Blake, R.L. \& McKay. D.A. (1986). A single-item measure of social suppont as a predictor of morbidity. Journal of Family Practice. 22, 82-84.

Blazer, D.G. (1982). Social support and mortality in an elderly community population. American Journal of Epidemiology. 115, 684-694.

Blessing-Moore, J.. Fritz, G. \& Lewinston, N.J. (1985). Selfmanagement programs for childhood asthma. A review. Chest, 87, s107-s110.

Boner. A.L., Niro, E., Antolini, L., Valetta, E.A. \& Gaburrow, D. (1985), Pulmonary function in bronchial hyperreactivity in asthmatic children with house-dust mite allergy during prolonged stay in the Italian Alps.

Annals of Allergy, 54, 42-45.

Boner, A.L., Niro, E., Antolini, L., Valetta, E.A. \& Gaburrow, D. (1993). Influence of allergen avoidance at high altitude on serum markers of eosinophil activation in children with allergic asthma. Clinical and Experimental Allergy, 23, 1021-1026.

Borne, H.W. van den \& Pruyn, J.F.A. (1983). Achtergronden en betekenis van lotgenotencontact bij kankerpatiënten. Academisch proefschrift, Tilburg.

Brink, W.T.J. van den. (1989). Indicaties voor opneming in het Nederlands Astmacentrum te Davos. In: Brink. W.T.J. van den, Berg. W.Chr. \& Sluiter, H.J. Symposiumboek (pp. 44-56). Leiden: Spruyt, Van Mantgem De Does bv.

Broadhead, W.E., Kaplan, B.H., James, S.A., Wagner, E.H., Schoenbach V.J., Grimson, R., Heyden, S., Tibblin, G. \& Gehibach, S.H. (1983). The epidemiologic evidence for a relationship between social support and health. American Journal of Epidemiology, 117, 521-537.

Broadhead W.E., Gehlbach, S.H., deGruy, F.V. \& Kaplan, B.H. (1989). Functional versus structural social support and health care utilization in a family medicine outpatient practice. Medical Care, 27, 221-233. 
Carter, R. (1986). New insights into the management and rehabilitation of the patient with pulmonary disease. Seminars in Respiratory Medicine, 8.

Carter, R., Nicotra, B., Clark, L. (1988). Exercise conditioning in the rehabilitation of patients with chronic obstructive pulmonary disease, Archives of Physical Medicine and Rehabilitation, 69, 118-222.

Casaburi, R. (1993). Exercise training in chronic obstructive lung disease. In: Casaburi, R. \& Petty, T.L. (Eds.) Principles and Practice of Pulmonary Rehabilitation (pp. 202-224). Philadelphia: Saunders.

Cassileth, B.R., Lusk, E.J., Strouse, T.B., Miller, D.S., Brown, L.L., Cross, P.A. \& Tenaglia, A.N. (1984). Psychosocial status in chronic illness; a comparative analysis of six diagnostic groups. New England Journal of Medicine, 3/I, 506-5II.

Centraal Beleidsorgaan voor de Intercollegiale Toetsing (CBO). (1995). Indicatiestelling voor behandeling van astmapatiënten in het hooggebergle. Den Haag: Ministerie van VWS.

CBS. (1987). Statistisch zakboek 1987, 's Gravenhage: Staatsuitgeverij.

Clark, C.F., Heaton,R.K. \& Wiens A.N. (1983)., Neuropsychological functioning after prolonged high-altitude exposure in mountaineering. Aviation Space and Environmental Medicine, 54, 202-207.

Cluss, P.A. (1986). Behavioral interventions as adjunctive treatments for chronic asthma. In: Hersen. M., Eisler, R.M. \& Miller P.M. (Eds.). Progress in behavior modification (Vol. 20, pp. 123-156). Orlando: Academic Press, Inc..

Cluss, P.A. \& Epstein, L.H. (1985). Measurement strategies in health psychology (pp. 403-432). New York: John Wiley and Sons.

Cobb. S. (1976). Social support as a. moderator of life stress. Psychosomatic Medicine, 38, 300-314.

Cockcroft, A.E., Saunders, M.J. \& Berry, G. (1981). Randomised controlled trial of rehabilitation in chronic respiratory disability. Thorax, 36, 200-203.

Cockcroft, A.E. (1988). Pulmonary rehabilitation. British Journal of Diseases of the Chest, 82, 220-225.

Cohen, F. \& Lazarus, R.S. (1979), Coping with the stresses of illness. In: Stone, G., Cohen, F., Adler, N. (Eds.), Health Psychology - a handbook (pp. 217-254). San Francisco: Jossey-Bass. Cohen, S. (1988). Psychosocial models of the role of social support in the etiology of physical disease. Health Psychology, 7. 269-297.

Cohen, S. \& Syme, S.L. (1985). Social support and health. London: Academic Press, Inc.

Colette. E.H. (1993). Astmapatiēnten in eerste en tweede lijn. Overeenkomsten en verschillen. Academisch proefschrift, Amsterdam.

College voor Ziekenhuisvoorzieningen. (1990). Advies inzake intramurale voorzieningen voor cara-patiënten (asmacentra). Utrecht, rapport 285.

Cox, N.J., Hendriks, J., Binkhorst, R.A. \& Herwaarden, C.L. van. (1991). Gunstige effecten van revalidatie in patiènten met CARA. Nederlands Tijdschrift voor Geneeskunde, 135, 987-91.

Cox, N.J., Herwaarden, C.L. van, Folgering. H. \& Binkhorst, R.A. (1988), Exercise and training in patients with chronic obstructive lung disease. Sports Medicine, 6, 180-192.

Coyne, J.C., Wortman, C.B. \& Lehman, D.R. (1988). The other side of support: Emotional overinvolvement and miscarried helping. In: Gotticb, B.H. (Ed.). Marshalling social support: Formats, processes and effects (pp. 305-330). Newbury Park: Sage Publications.

Creer, T.L. (1983). Response: self-management psychology and treatment of childhood asthma. Journal of Allergy and Clinical Immunology, 72, 6017-610.

Creer, T.L. Backial, M., Burns, K.L. Leung, P., Marion, R.J., Miklich, D.R., Morril, C., Taplin. P.S., \& Vliman, S. (1988). Living with asthma: Part I. Genesis and development of a self-management program for childhood asthma. Journal of Asthma, 25, 335-365.

Creer. T.L. Kotses, H., \& Reynolds, R.V.C. (1989), Living with asthma: Part II. Beyond CARIH. Journal of Asthma, 26, 31-51.

Creer, T.L. (1978). Asthma: Psychological aspects and management. In: Middleton JE, Reed CE \& Ellis EF (eds). Allergy, principles and practice (pp. 796-811). St. Louis, MO.: Mosby.

Creer, T.L. (1982). Asthma. Journal of Consulting and Clinical Psychology, 50, 912-921.

Damoiseaux V. \& Visser. A.Ph. (1988). Patiëntenvoorlichting. Een interdisciplinaire benadering. Assen/Maastricht: Van Grocum.

DeCencio, D.V. Leshner, M. \& Leshner, B. (1968), Personality characteristics of patients with chronic obstructive pulmonary emphysema. Archives of Physical Medicine and Rehabilitation, 49, 471-475.

Decramer, M. (1992). Puimonary rehabilitation: Art or science? European Respiratory Journal, 5, 155-156. 
Deenen Th.A.M., Lammers, W.L.M., De Weerdi, I., Jonker, R. \& Klip, E.C. (1994). Patièntenvoorlichting en selfmanagement bij patienten met een emstige vorm van CARA. Tujbchrift Gesondheidshevordering. 3 , 131-141.

Dekhuijzen, P.N., Beek. M.M., Folgering. H.T. \& Herwaanden, C.L. van. (1990). Psychological changes during pulmonary rehabilitation and target-flow inspiratory muscle training in COPD patients with a ventilatory limitation during exercise. International Journal of Rehabilitation Rescarch, 13, 109-117.

Dekker, E \& Groen, J. (1956). Reproducible psychogenenic attacks of asthma: a laboratory study. Journal of Psychosomatic Resranch, 1. 58-67.

Dekker, F. W. (1993). Asthma and COPD in general practice. Studies on the quality of care. Academisch proefschrift, Leiden.

Devins, G.M. \& Edwards, P.J. (1988). Self-efficacy and smoking reduction in chronic obstructive pulmonary disease. Behavior Research and Therapy, 26, 127-135.

Dijkstra, M.C.F.M. (1995). Development, implementation, and evaluation of no Dutch smoking prevention programs. Academisch proefschrif., Maastricht.

Dirks, J.F., Kinsman, R.A., Jones, N.F., Spector, S.L., Davidson, P.T. \& Evans, N.W. (1977). Panic fear: a personality dimension related to length of hospitalization in respiratory illness. The Journal of Asthma Re. search, 14, 61-71.

Dirks, J.F. (1978). The psychomaintenance of bronchial asthma: a review and preliminary integration of panic. fear research in asthma. Psychophysiology Research Laboratories, National Jewish Hospital Research

Center Denver, Colorado, Report no, 54.

Dudley, D.L. Glaser E.M., Jorgensen, B.N., \& Lorgan, D.L. (1980). Psychosocial concomitants to rehabilitation in chronic obstructive pulmonary disease. Part 1. Psychosocial and psychological considerations. Chest, 77. $413-420$.

Dudley, D.L. \& Sitzman, J. (1993). Psychobiologic evaluation and rehabilitation in pulmonary disease. In: Casaburi, R. \& Petty. T.L. (Eds.). Principles and practice of Pulmonary Rehabilitation (pp.252-274). Philadelphia: Saunders.

Dudley, D.L., Wermoth. C. \& Hague, W. (1973). Psychosocial aspects of care in the chronic obstructive pulmonary disease patient. Heart and Lung, 2, 389-393.

Dunkel-Schetter, C., Blasband, D.E., Feinstein, L.G. \& Herbert, T.B. (1992). Elements of supportive interacions: When are attempts to help effective? In: Spacepan, S. \& Oskamp. S. (Eds.), Helping and being helped: Naturalistic studies (pp.83-114). Newbury Park: Sage Publications.

Dunkel-Schetter, C. \& Wortman, C.B. (1982). The interpersonal dynamics of cancer. In: Friedman, H.S. \& DiMatteo, M.R. (Eds.). Interpersonal issues in health care (pp. 69-100). New York: Academic Press, Inc..

Eckenrode, J. (1991). Introduction and overview. In: Eckenrode J (Ed.). The social context of coping (pp. I. 12). New York: Plenum Press.

Eekhof, J.A.H., Selm, J.H. van, Tombrock, C.F.J.L., Hoogslag. G.F.W. \& Kaptein, A.A. (I99I), De sexuali teitsbeleving van oudere patiënten met COPD. Huisarts en Wetenschap, 34, 527-530.

Emery, C.F., Leatherman, N.E., Burker. E.J. \& MacIntyre, N.R. (1991). Psychological outcomes of a pulmonary rehabilitation program. Chest, 100, 613-617.

Feinstein, A.R. (1987). Clinimetric perspectives. Journal of Chronic Diseases, 40, 635-640.

Fireman, P.. Friday, G., Gira, C., Vierthaler, W.A. \& Michaels, L. (1981). Teaching self-management skills to asthmatic children and their parents in an ambulatory care setting. Pediatrics, 68, 341-348.

Fishman, D.B. \& Petty, T.i. (1971). Physical, symptomatic and psychological improvement in patients receiving comprehensive care for chronic airway obstruction. Journal of Chronic Diseases, 24, 775-785.

Fishman, A.P. (1994). Pulmonary rehabilitation research. American Journal of Respiratory and Critical Care Medicine, 149, 825-833.

Fix, A.J., Golden, C.J. \& Daughton, D., Kass, I. \& Bell, C.W. (1982). Neuropsychological deficits among patients with chronic obstructive pulmonary disease. International Journal of Neuroscience, 16. 99-105.

Fletcher, C., Peto, R., Tinker, C. \& Spiezer, F.E. (1976). The natural history of chronic bronchitis and emphysema. Oxford: Oxford University Press.

Folgering. H., Dekhuijzen, R., Cox. N. \& Herwaarden, C.L. van. (1991). The rationale of pulmonary rehabilitation. European Respiratory Review, 6, 213-250.

Folkman, S. (1992). Making the case for coping. In: Carpenter, B.N. (Ed.). Personal coping. Theory, research, and application (pp. 31-46). Westport: Praeger Publishers. 
Gatchel, R.J. \& Baum, A. (1983), An introduction to health psychology. Readings (Mass.), Addison-Wesley. Gift, A.G., Plaut, S.M. \& Jacox, A. (1986). Psychologic and physiologic factors related to dyspnea in subjects with chronic obstructive pulmonary disease. Heart and Lung, I5, 595-601.

Gimeno, F., Smith, A.N.A., Berg, W.C., Steenhuis, E.J., Orie, N.G.M. \& Sluiter, H.J. (1979). Onderzoek naar het effect van longrevalidatie bij mannen met CARA. Nederlands Tijdschrift voor Geneeskunde, 123, 1429. 1434.

Gimeno, F., Smith, A.N.A., Steenhuis, E.J., Veenen, R. van \& Berg. W.C. (1986). Vervolgonderzoek naar het effect van longrevalidatie bij mannen met CARA. Nederlands Tijdschrift voor Geneeskunde, 130, $351-353$.

Goldstein, L.H. (1990). Behavioral and cognitive-behavioral treatments for epilepsy: A progress review. British Journal of Clinical Psychology, 29, 257-269.

Goodall, T.A. \& Halford, W.K. (1991). Self-management of diabetis mellitus, a critical review. Health Psychology, 10, 1-8.

Grant, I., Prigatano. G.P., Heaton, R.K., MeSweeny, A.J., Wright, E.C. \& Adams, K.M. (1987). Progressive neuropsychologic impairment and hypoxemia. Relationship in chronic obstructive pulmonary disease. Archives of General Psychiatry, 44, 999-1006.

Green, L.W., Werlin, S.H., Schauffler, H.H. \& Avery, C.H. (1977), Research and demonstration issues in selfcare: Measuring the decline of medicocentrism. Health Education Monographs, 5, 161-189.

Greer, D.S. (1987), Quality of life measurement in the clinical realm. Journal of Chronic Diseases, 40, 629. 630.

Guyatt, G.H., Berman, L.B., Townsend, M., Pugsley, S.O. \& Chambers, L.W. (1987a). A measure of quality of life for clinical trials in chronic lung disease. Thorax, 42, 773-78.

Guyatt, G.H., Townsend, M., Berman, L.B. \& Pugsley, S.O. (1987b). Quality of life in patients with chronic airflow imitation. British Journal of Diseases of the Chest, 8I, 45-54.

Guyatt, G.H. Berman, L..B. \& Townsend, M. (1987c). Long-term outcome after respiratory rehabilitation. The Canadian Medical Association Journal, 137, 1089-1095.

Haas, A., \& Cardon, H. (1969). Rehabilitation in chronic obstructive pulmonary disease. Medical Clinics of North America, 53, 593-606.

Haas, F. \& Axen, K. (1991). Pulmonary Therapy and Rehabilitation: Principles and Practice. Baltimore: Williams \& Wilkins.

Haas, F., Salazar-Schicchi, J. \& Axen. K. (1993), Desensitization to dyspnea in chronic obstructive pulmonary disease. In: Casaburi, R. \& Petty. T.L. (Eds.). Principles and Practice of Pulmonary Rehabilitation (pp. 241-251). Philadelphia: Saunders.

Haes, J.C.J.M. de. (1988), Kwaliteit van leven van kankerpatiënten. Academisch proefschrift, Leiden.

Haes, J.C.J.M. de \& Knippenberg van, F.C.E. (1985). The quality of life of cancer patients. A review of the literature, Social Science and Medicine, 20, 809-17.

Hargreave, F.E., Sterk, P.J. \& Ramsdaie, E.H. (1985). Inhalation challenge tests and airway responsiveness in man. Chest, 87, s202-s206.

Herwaurden, C.L.A. yan. (!986). Een luchtige beschouwing over kortademigheid. Rede uitgesproken bij de aanvaarding van hẹt ambt van buitengewoon hoogleraar. Katholieke Universiteit Nijmegen.

Hindi-Alexander, M.C. (1985). Decision making in asthma self-management. Chest, 87, s100-s104.

Hodgkin, J.K. (1986). Organization of a pulmonary rehabilitation program. Clinics in Chest Medicine. 7. 54 I-549.

Hodgkin, J.E. (1990). Pulmonary rehabilitation. Clinics in Chest Medicine, II, 447-460.

Hornbein, T.F., Townes, B.D., Schoene, R.B., Sutton, J.R. \& Houston, C.S. (1989). The cost to the central, nervous system of climbing to extremely high altitude. New England Journal of Medicine, 321, 1714-1719.

House, J.S. \& Kahn, R.L. (1985). Measures and concepts of social support. In: Cohen, S. \& Syme, S.L. Social support and health (pp.83-105). London: Academic Press, Inc..

Huisman, S. (1982). De ontwikkeling' van een 'Zelfbeoordelingsschaal voor Welbevinden en Dagelijkse Activiteiten', Doctoraal' scriptie, Universiteit van Amsterdam.

Huppert, F.A. (1982). Memory impairment associated with chronic hypoxia. Thorax, 37, 858-860. Jacobson. N.S., Folette, W.C. \& Revenstorf, D. (1984). Psychotherapy outcome research: Methods for reporting variability and evaluating clinical significance. Behavior Therapy, 15, 336-352.

Kaplan, B.H., Cassel, J.C. \& Gore S. (1977). Social support and health. Medical Care, 15, 47-58.

Kaptein. A.A. (1982), Illness behavior of patients with asthma. Academisch proefschrift. Amsterdam. 
Kaptein, A.A. (1988), Cara en sexualiteit. Contrastma, 16. 752.729.

Kaptein, A.A. (1988b). Leven met CARA. Utrecht: Bohn, Scheltema \& Holkema.

Kaptein, A.A. \& Dekker, F.W. (1987a). CARA: een uitdaging voor de gerondheidspsycholoog. Gestrag \& Gezondheid, 15, 49-57.

Kaptein, A.A., Dekker, F.W., Gill, K., Waan, M.A.C. van der. (1987b). Undertreatment of asthma in Dutch general practice. Family Practice, 4, 219-225.

Kaptein, A.A. Dekker, F.W., Dekhuijzen, P.N.R., Wagenaar, J.P.M. \& Janssen, P.J. (1987d). De 12-minutenlooptest bij patiènten met een chronische uitademingsstoomis. Lopen in het laboratorium en lopen in het leven. Nederlands Tudschrift woor Geneeskunde, 131, 1717-1721.

Kaptein, A.A., Dekker, F.W.. Waart, M.A.C. van der \& Gill, K. (1988a). Health psychology and asthma: current status and future directions. In: Maes, S. Spielberger, C.D., Defares, P.B. \& Sarason, I.G., (eds). Topics in health psychology (pp. 157-170). New York: John Wiley \& Sons.

Kaptein, A.A. Brand, P.I.P., Dekker, F.W., Kerstjens, H.A.M., Postma, D.S., Sluiter, H.J. \& the Dutch CNSL.D-study group. (1993). Quality-of-life in a long-term multicentre trial in chronic nonspecific lung disease: assessment at baseline. European Respiratory Journal, 6. 1479-1484.

Kersten, L. (1990). Changes in self-concept during pulmonary rehabilitation, Part 1. Heart and Lung, 19, 456462.

Kersten, L. (1990). Changes in self-concept during pulmonary rehabilitation. Part 2. Heart and Lung, 19, 463. 470.

Kinsman, R.A., Luparello, T.J., O'Banion, K. \& Spector, S.L. (1973), Multidimensional analysis of the subjective symptomatology of asthma. Psychosomaric Medicine, 35, 250-267.

Kinsman, R.A., Dirks, J.F. \& Jones, N.F. (1982). Psychomaintenance of chronic physical illness. In; Millon T. Green G, Meager R (eds). Handbook of clinical hralth psychology (pp. 435-466). New York: Plenum Press. Kinsman, R.A.. Dirks, J.F. \& Jones, N.F. (1980). Psychomaintenance of chronic physical illness: clinical assessment of personal styles affecting medical management. In: Report no. 87, National Jewish Hospital Research Center Denver, Colorado.

Kinsman, R.A., O'Banion, K., Resnikoff, P., Luparello, T.Y, \& Spector, S.L. (1973), Subjective symptoms of acute asthma within a heterogenuous sample of asthmatics. Journal of Allergy and Clinical Immunology, 52, 284-329.

Kinsman, R.A., Spector, S.L., Shucard, D.W. \& Luparello, T.J. (1974), Observation on patterns of subjective symptomatology of acute asthma. Psychosomatic Medicine, 36, 129-143.

Kinsman, R.A., Wray Dahlem, N., Spector, S. \& Staudenmayer, H. (1977), Observations on subjective symptomatology, coping behavior, and medical decision in asthma. Psychosomatic Medicine, 39, 102-119.

Knippenberg. F.C.E. van \& Haes, J.C.J.M. de. (1988). Measuring the quality of life of cancer patients: Psychometric properties of instruments. Journal of Clinical Epidemiology, 41, 1043-1053.

Kobus, M.H. \& Carlier, J.M. (1994), Kenmerken van het revalidatieproces. Projectverslag. Utrecht: NZf/Con sult. Publicatienummer: 892.001 .

Krop, H.D., Block, A.J. \& Cohen, E. (1973). Neuropsychologic effects of continuous oxygen therapy in chronic obstructive pulmonary disease. Chest, 64, 317-322.

Lako. C.J. (1983). Schoolverzuim op de bașisschool. Tijdschrift voor Sociale Gezondheidszorg, 61, $776-783$.

Lane, C. \& Hobfoll, S.E. (1992). How loss affects anger and alleniates potentiall supporters. Journal of Consulting and Clinical Psychology, 60, 935-942.

Larcombe, N.A. \& Wilson, P.H. (1984). An evaluation of cognitive-behavior therapy for depression in patients with multiple sclerosis. British Journal of Psychiatry, 145, 366-371.

LeBaron, S., Zeltner, L.K., Ratner, P. \& Kniker, W.T. (1985). A controlled study of education for improving compliance with cromolyn sodium (Intal): the importance of physician-patient communication. Annals of Allergy, 55, 811-818.

Lende, R. van der. (1989), CARA. In: Maas, P.J. van der, Hofman, A. \& Dekker, E. (red.), Epidemiologie en gezondheidsbeleid (pp. 166-179). Alphen a/d Rijn: Samsom Stafleu.

Lende, R. van der. (1979). De grootte van het probleem. In: Roseboom, G. \& Schüller, C.F. \& Zijverden, J. van (eds.). De astmatische patiènt' (pp. 11-32). Alphen a/d Rijn: Stafleu.

Lende, R. van der, Jansen-Koster. E.J., Knijpstra, S., Meinesz, A.F., Wever, A.M.H. \& Orie, N.G.M. (1975), Definitie van CARA in epidemiologie en preventie. Nederlands Tijdschrift voor Geneeskunde. 119. 1975. 1987. 
Lertzman, M.M. \& Chemiack, R.M. (1976). Rehabilitation of patients with chronic obstructive pulmonary disease. American Review of Respiratory Disease, 114, 1145-1165.

Lester, D.M. (1973). The psychological impact of chronic obstructive pulmonary disease. In: Johnson, R.F. (ed.), Pulmonary care (pp.341-354). New York: Grune and Stratton.

Leuschner, R.M. \& Bochm, G. (1981). Pollen and inorganic particles in the air of climatically very different places in Switzerland. Grana, 20, 161-167.

Levinson, R. (1979). Effects of thematically relevant and general stressors on specificity of responding in asthmatic and nonasthmatic subjects. Psychosomatic Medicine, 4I, 28-39.

Lichtman, R.R., Taylor, S.E. \& Wood, J.V. (1987). Social support and marital adjustment after breast cancer. Journal of Psychosocial Oncology, 5, 47-74.

Light, R.W., Merrill, E.J., Despars, J.A., Gordon, G.H. \& Mutalipassi, L.R. (1985). Prevalence of depression and anxiety of patients, with COPD. Relationship to functional capacity. Chest, 87, 35-38.

Luparello, T., Leist, N., Louri, C. \& Swett P. (1970). The interaction of psychologic agents on airway reactivity in asthmatic subjects. Psychosomatic Medicine, 32, 509-513.

Luteijn, F., Starren, J., \& Dijk, H. van. (1985). Handleiding Nederlandse Persoonlijkheids Vragenlijst. Lisse: Swets \& Zeitlinger.

Maes. S. \& Schlösser, M. (1988). Changing health behaviour outcomes in asthmatic patients: a pilot intervention study. Social Science and Medicine, 26, 359-364.

Maes, S. \& Schlösser, M. (1987). The role of cognition and coping in health behavior outcomes of asthmatic patients. Current Psychological Research and Reviews, 6, 79-90.

Maillé, A.R., \& Kaptein, A.A. ( I991), Omgaan met CARA. Sociaal-wetenschappelijk CARA-onderzoek: op weg. naar de roekomst. Leusden: Nederlands Astma Fonds.

Maillé, A.R., Koning. C.J.M., Zwinderman, A.H. \& Kaptein, A.A. (1994). De ontwikkeling van een kwaliteit van leven vragenlijst voor CARA-patiènten. Gedrag en Gezondheid, 22, 35-43.

Maillé, A.R. \& Kaptein, A.A. (1992). Een research-agenda voor gedragswetenschappelijk Cara-onderzoek. Nederlands Tijdschrift voor Geneeskunde, 136, 474-477.

Make, B.3. (1986). Pulmonary Rehabilitation: Myth or reality? Clinics in Chest Medicine, 74, 519-540.

Mall، R. \& Medeiros, M. (1988), Objective evaluation of results of a pulmonary rehabilitation program in a community hospital. Chest, 94, 1156-1160.

MeFadden, E., Luparello. T., Lyons, H. \& Bleeker, E. (1969). The mechanism of suggestion in the induction of acute asthma. Psychosomatic Medicine, 31, 134-143.

MeGavin, C.R., Gupta, S.P., Lloyd, E.L. \& McHardy. G.J.R. (1977). Physical rehabilitation for the chronic bronchitic: results of a controlled trial of exercises in the home. Thorax, 32, 307-311.

McKay, D.A., Blake, R.L., Colwill, J.M., Brent E.E., McCanley, J., Umlauf, R., Stearman, G.W. \& Kivlahan, D. (1985). Social supports and stress as predictors of illness. Journal of Family Practice, 20, 575-581.

McNichol. K., Williams, H., Allan, J. \& McAndrew. (1973). Spectrum of asthma children-III. Psychological andi social components, British Medica! Journal, 4, !6-20.

MeSweeny, 1. (1988), Quality of life in relation to COPD. In: McSweeny, J. \& Grant, 1. (Eds.). Chronic Obstructive Pulmonary Disease: A behavioral perspective. Lung Biology in Health and Disease, Vol_36 (pp. 59i-82). New York: Marce! Dekker, İnc..

McSweeny, A.J., Grant, I. \& Heaton, R.K., Adams, K.M. \& Timms, R.M. (1982). Life quality of patients with chronic obstructive pulmonary disease. Archives of Internal Medicine, 142, 473-478.

McSweeny, A.J., Heaton, R.K., Grant, I., Cugell, D., Solliday, N. \& Timms, R. (1980). Chronic Obstructive Pulmonary Disease: Sociocmotional adjustment and life quality: Chesr. 77, s309-s311.

Menges, L.J. Gezondheid en ziekte. Gedragswetenschappelijke verkenningen (p. 42). Alphen aan den Rijn/Brussel: Samson Stafleu.

Miller, F.M. (1967). Rehabilitation of patients with chronic obstructive pulmonary disease. Medical Clinics of North America, 51, 349-361.

Mölken, M.P.M.H van, Doorslaer, E.K.A. van \& Rutten, F.F.H. (1989)、CARA in cijfers -verslag van een pilot-sfudie. Maastricht: Institute for Medical Technology Assessment.

Monroe, S.M., Bromet. E.J., Connell, M.H. \& Steiner, S.C. (1986). Social support, life events, and depressive symptoms: a I-year prospective study. Journal of Consulting and Clinical Psychology, 54, 424-431.

Morris, P.L. Robinson, R.G., Raphael, B. \& Bishop, D. (1991). The relationship between the perception of social support and post-stroke depression in hospitalized patients. Psychiatry, 54, 306-316. 
Moser, K.M. Bokinsky, G.E., Savage, R.T., Archibald, C.J. \& Hansen, P.R. (1980). Results of a comprehensive rehabilitation program. Physiologic and functional effects on patients with chronic obstructive pulmonary disease. Archives of Internal Medicine, 140, 1596-1601.

Murrell, S.A., Himmelfarb, S. \& Wright, K. (1983). Prevalence of depression and its correlates in older adults. American Journal of Epidemiology, 117, 172-185.

NCCZ (1994). Chronisch zieken aan zet. Tussenhalans chronisch ziekenbeleid, 1991-1994. Zoetermeer. NCCZ. 5.

Nicholas, J.J., Gilbert, R., Gabe, R. \& Auchincloss, J.H. (1970). Evaluation of an exercise therapy program for patients with chronic obstructive pulmonary disease. American Review of Respiratory Discase, 102, 1-9.

Niederman, M.S., Clemente, P.H., Fein, A.M. Feinsilver, S.H., Robinson, D.A., llowite J.S. \& Bemstein, M.G. (1991). Benefits of a multidisciplinary pulmonary rehabilitation programme: Improvements are independent of lung function. Chest, 99, 798-804.

Ojanen, M., Lahedensuo, A., Laitinen, J. \& Karvonen, J. (1993). Psychosocial changes in patients participating in a chronic obstructive pulmonary disease rehabilitation program. Respiration, $00,96-102$.

Orie, N.G.M. Sluiter, H.J., de Vries, K. \& Tammeling. G.J. (1961). Chronische aspecifieke respiratoire aandoeningen. Nederlands Tijdschrift woor Geneeskunde, 105, 2136-2139.

Peersmann-Rijlaarsdam, J.A., Breederveld, N., Wiel, H.B.M. van de, Weijmar Schultz, W.C.M., Koetter, G.H. \& Klip. E.C. (1984). Cara en sexualiteit. Tijdschrift voor Sexuologie, 18, 272-281.

Petty, T.L., Nett, L.M., Finigan, M.M., Brink, G.A. \& Consello, P.R. (1969), A comprehensive care program for chronic obstructive airway obstruction. Methods and preliminary evaluation of symptomatic and functional improvement. Annals of Internal Medicine, 70, 1109-1120.

Petty, T.L. (1977). Pulmonary rehabilitation. Respiratory Care, 22, 68-77.

Petty, T.L. (1986). Health, sex, and better quality of life for your COPD-patient. Medical Aspects of Human Sexuality, 8, 70-85.

Pilisuk, M., Boylan, R. \& Acredolo, C. (1987). Social support, life stress, and subsequent medical care utilization. Health Psychology, 6, 273-288.

Prigatano, G.P., Parsons. O., Wright, E. Levin, D.C. \& Hawryluk, G. (1983). Neuropsychological test perfor mance in mildly hypoxemic patients with chronic obstructive pulmonary disease. Journal of Consulring and Clinical Psychology, 51, 108-116.

Prigatano. G.P.. Wright, E.C. \& Levin, D.C. (1984). Quality of life and its predictors in patients with mild hypoxemia and chronic obstructive pulmonary disease. Archives of Internal Medicine, 144, 1613-1619.

Quanjer. Ph.M. (1983). Standardized lung function testing. Bullitin of European Physiopathological Respiration. 19. $51-595$.

Raad voor gezondheidsonderzoek (RGO)(1991). Advies chronische aandoeningen: prioriteiten voor onderzoek. Advies, no.7. 's-Gravenhage.

Renfroe, K.L. (1988). Effect of progressive relaxation on dyspnea and state anxiety in patients with chronic obstructive pulmonary disease. Heart and Lung, 17, 408-413.

Revenson, T.A. (1994). Social support and marital coping with chronic illness. Annals of Behavioral Medicine, 16. 122-130.

Revenson, T.A. (1990). Social support processes and chronically ill elderly: Patients and providers perspectives. In: Giles, H., Coupland, N. \& Wiemann, J. (Eds.). Communication, health and the elderly (pp. 92-113). Manchester, UK: University of Manchester Press.

Richardson, G.M. \& McGrath, P.J. (1989). Cognitive-behavioral therapy for migraine headaches: A minimaltherapist-contact approach versus a clinic based approach. Headache, 29, 352-356.

Ridder, D.T.D. de \& Schreurs, K.M.G. (1994). Coping en sociale steun van chronisch zieken. Een overzicht van recent onderzoek. NCCZ-reeks Zorg, opvang en begeleiding van chronisch zieken, Zoetermeer.

RIVM. (1993). Volksgezondheid Toekomst Verkenning. De gezondheidstoestand van de Nederlandse bevolking in de periode 1950-2010. Den Haag: SDu.

Roberts, S.J. (1988). Social support and heip seeking: Review of the literature. Advances in Nursing Science, 10, 1-11.

Rolnick, SJ. (1988). Self-management of pediatric asthma: four programs being studied. Journal of Pediatric Health Care, 2, 264-266.

Rosser, R. \& Guz, A. (1981). Psychological approaches to breathlessness and its treatment. Journal of Psychosomatic Research, 25, 439-447. 
Ruberman, W., Weinblatt, E., Goldberg. J.D. \& Chaudhary, B.S. (1984), Psychosocial influences on mortality after myocardial infarction. New England Journal' of Medicine, 311, 552-559.

Rijcken, B. \& Verkerck, P.H. (1988). Schoolverzuim en Cara. Tijdschrift voor Jeugdgezondheidszorg. 20, 2829.

Sahn, S.A., Nett, L.M. \& Petty, T.L. (1980). Ten year follow-up of a comprehensive rehabilitation program for severe COPD. Chest, 77, 311-314.

Sarason, B.R., Sarason, I.G. \& Pierce, G.R. (1990). Traditional views of social support and their impact on assessment. In: Sarason, B.R., Sarason, L.G. \& Pierce, G.R. (Eds.) Social support: an interactional view (pp. 9-25). New York: John Wiley \& Sons.

Sassi-Dambron, D.E., Eakin, E.G., Ries, A.L. \& Kaplan. R.M. (1995). Treatment of dyspnea in COPD. A controlled clinical trial of dyspnea management strategies. Chest, 107, 724-729.

Schayck, C.P. van, Dompeling, E. \& Herwaarden, C.L.A. van. (1991). Bronchodilator treatment in moderate asthma or chronic bronchitis: continuous, or on demand? British Medical Journal, 303, 1426-1431.

Schoot, T.A.W. van der, Kaptein, A.A., Dekker, F.W., Lammers, W.L.M. \& Brink, W.T.J. van den. (1988). Psychologische kenmerken en de door henzelf ervaren lichamelijke belemmeringen van volwassen patiënten in het Nederlands. Astmacentrum Davos. Nederlands Tijdschrift voor Geneeskunde, 132, 1105-1108.

Schoot, T.A.W. van der \& Kaptein, A.A. (1990). Pulmonary rehabilitation in an asthma clinic., Lung, 168', 5495-5501.

Schoot, T.A.W. van der, De Weerdt, I., Kaptein, A.A., Dekker, F.W., Deenen, Th.A.M. \& Speelberg. B. (1993). Gunstige effecten van een verbliji in het Nederlands Astmacentrum Davos op medische consumptie en kwaliteit van leven bij CARA-patiënten. Nederlands Tijdschrift voor Geneeskunde, 137, 197-201.

Schrier, A.C., Dekker, F.W., Kaptein, A.A. \& Dijkman, J.H. (1990), Quality of life in elderly patients with chronic nonspecific lung disease seen in family practice. Chest, 98, 894-899.

Schwab, J.J., Traven, N.D. \& Warheit, G.J. (1978). Relationships between physical and mental illness. Psychosomatics, 19, 458-463.

Schwarz, S.P. \& Blanchard, E.B. (1991). Evaluation of a psychological treatment for inflammatory bowel disease. Behavior Research and Therapy, 29, 167-177.

Sensky, T. (1990). Patients' reaction to illness: Cognitive factors determine and are amenable to treatment. British Medical Journal, 300, 622-623.

Shapiro, B.A., Vostinak-Foley, E. Hamilton, B.B. \& Buchler, J.H. (1977). Rehabilitation in chronic obstructive pulmonary disease: a two-year prospective study. Respiratory Care, 22, 1045-1057.

Silver, R.C., Wortman, C.B. \& Crofton, C. (1990). The role of coping in support provision: The self presentational dilemma of victims of life crises. In: Sarason, B.R., Sarason, I.G. \& Pierce, G.R. (Eds.). Social support: an interactional view (pp. 397-426). New York: Wiley:

Sinclair, D.J.M. \& Ingram, C.G. (1980). Controlled trial of supervised exercise training in chronic bronchitis. British Medical Journal, 1, 519-521.

Skinner, J.B., Erskine, A., Pearce, S., Rubenstein, 1., Taylor, M. \& Foster, C. (1990). The evaluation of a cognitive-behavioral treatment program in outpatients with chronic pain. Journal of Psychosomatic Research, 34. 13-19.

Sluiter, H.J. (1986). Cara is geen diagnose. Nederlands. Tijdschrift voor Geneeskunde, 130, 2201-2203.

Speelberg, B., Folgering, H.T.M., Sterk, P.J. \& Herwaarden, C.L.A. van. (1992). Longfunctie van volwassen patiënten met asthma bronchiale of chronische obstructieve aandoening, voor en na een verblijf van 3 maanden in het Nederlands Astmacentrum Davos. Nederlands Tijdschrift voor Geneeskunde, 136, 469-474.

Speelberg. B. Folgering. H.T.M., Sterk, P.J. \& Herwaarden, C.L.A. van. (1994). Peak expiratory flow rate, symptom score, and medical use in patients with asthma or chronic airflow limitation before and 1 year after a stay in the alpine climate. Journal of Cardiopulmonary Rehabilitation, 14, 391-398.

Speight, A.N.P., Lee, D.A. \& Hey, E.N. (1983). Underdiagnosis and undertreatment of asthma in childhood. British Medical Journal, 286, 1253-1255.

Staudenmayer, H., Kinsman, R.A. \& Jones, N.F. (1978). Attitudes towards respiratory illness and hospitalization in asthma: Relationship with personality, symptomatology and treatment response. Journal of Nervous and Mental Disease, 166, 624-634.

Stuurgrocp Toekomstscenario's Gezondheidszorg. (1992). Chronische ziekten in het jaar 2005, deel 4: Scenario's voor beleid. Houten/Antwerpen: Bohn Stafleu Van Loghum. 
Stuurgroep Toekomstscenario's Gezondheidszorg. (1990). Chronische ziekten in het jaar 2005, deel 2: Scena: rio's woor CARA 1990-2005. Houten/Antwerpen: Bohn Stafleu Van Loghum.

Surtees, P.G. (1980). Social support, residual adversity and depressive outcome. Social Pxychiatry, 15, 71-80.

Swerts, P., Kretzers, L., Terpstra-Lindeman, E., Verstappen, F. \& Wouters, E.F.M. (1990). Exercise reconditioning in the rehabilitation of patients with chronic obstructive pulmonary discase: a short- and long-term analysis. Archives of Physical Medicine and Rehabilitation. 71, 570-573.

Tarrier, N. \& Maguire, P. (1984). Treatment of psychological distress following mastectomy; An initial repont. Behavior Research and Therapy, 22, 81-84.

Taylor, S.E. \& Dakof, G. (1988). Social support and the cancer patient. In: Spacapan, S. \& Oskamp, S. (Eds), The social psychology of health (pp. 95-118). Newbury Park. CA: Sage.

Thoits, P.A. (1991). On merging identity theory and stress research. Social Psychology Qwarterly, 54, $101-112$.

Thoits, P.A. (1982). Conceptual, methodological, and theoretical problems in studying social support as a buffer against life stress. Journal of Health and Social Behavior, 23, 145-159.

Thompson, S.C. \& Pitts, J.S. (1992). In sickness and in health: Chronic illness, marriage and spousal caregiving. In: Spacapan, S., Oskamp, S. (Eds), Helping and being helped: naturalistic sfudies. Newbury Park, CA: Sage, 95-118.

Tiep. B.L. (1993). Pulmonary rehabilitation program organization. In: Casaburi, R. \& Petty, T.L. (Eds.). Princi. ples and Practice of Pulmonary Rehabilitation (pp.302-316). Philadelphia: Saunders.

Toshima, M.T., Kaplan, R.M., Ries, A.L. (1990), Experimental evaluation of rehabilitation in chronic obstructive pulmonary disease: short-term effects on exercise endurance and health status. Health Psychology, 9. 237-252.

Townes, B.D., Hombein, T.F. \& Schoene, R.B. (1984). Human cerebral function at extreme altitude. In: West. J.B. \& Hahiri, S. (Eds.). High altinude and man (pp. 31-36). Bethesda MD: American Physiological Society.

Tweede Kamer, vergaderjaar 1990-1991. (1991), Chronisch-ziekenbeleid. Chronische patienten niet buiten spel. Den Haag. SDu, 4.

Vaate, E. bij de \& Deenen, Th.A.M. (Eds.)(1995). De Cara de haas. Een voorlichringsprogramma voor volwassen Cara-patiênten. Davos: Nederlands Astmacentrum Davos.

Vromans, I.S.Y. (1990), Omgaan met astma. Stichting voor sociale gezondheidszorg. Zeist: Kerkebosch bv.

West, H., \& Schoot, T.A.W. van der. (1992). Ademhalen en ademen bij CARA-patienten: oefenen of therapie? Bewegen en Hulpverlening, 9, 52-66.

Wijkstra, P.J., Altena, R. van, Kraan, J., Otten, V., Postma, D.S. \& Koeter, G.H. (1994). Quality of life in patients with chronic obstructive pulmonary disease improves after rehabilitation ar home. European Respiratory Journal, 7, 269-273.

Williams, A.W.. Ware, J.E. \& Donald, C.A. (1981). A model of mental health, life events, and social supports applicable to general populations. Journal of Health and Social Behavior, 22, 324-332.

Williams, S.J. (1989a). Assessing the consequences of chronic respiratory disease: a critical review. International Disability Studies, 11, 161-166.

Williams, S.J. \& Bury, M.R. (1989b). 'Breathtakıng': the consequences of chronic respiratory disorder. International Disability Studies, 11, 114-120.

Williams, S.J. \& Bury. M.R. ( I989c). Impairment, disability and handicap in chronic respiratory illness. Social Science and Medicine, 29, 609-616.

World Health Organization. (1980). International Classification of Impairments, Disabiliries and Handicaps. Genève: World Health Organization.

Wortman, C.B. \& Conway, T.L. (1985). The role of social support in adaptation and recovery from physical illness. In: Cohen, S. \& Syme, S.L. (Eds.). Social support and health (pp. 281-302). London: Academic Press, Inc..

Yellowlees, P.M., Haynes, S., Potts, N. \& Ruffin, R. (1988). Psychiatric morbidity in patients with lifethreatening asthma: initial report of a controlled study. The Medical Journal' of Australia. 149. 246-249.

Yellowlees, P.M., Alpers, J.H., Bowden, J.J., Bryant, G.D. \& Ruffin, R.E. (1987a). Psychiatric morbidity in patients with chronic airflow obstruction. The Medical Journal of Australia, 146, 305-307.

Yellowlees, P.M. (1987b). The treatment of psychiatric disorders in patients with chronic airways obstruction. The Medical Journal of Australia, 147, 349-352.

Zuidema, P. (1970). Huistofallergeen in het hooggebergte. Nederlands Tijdschrift voor Geneeskunde, 114, 1042-1047. 


\section{BIJL.AGEN}

\section{BIJLAGE I}

Schaamte; Respiratory Ilness Opinion Survey (Staudenmayer, 1978)

Hieronder staan 6 uitspraken die mensen hebben gedaan over het hebben van ademhalingsmoeilijkheden.

Wilt $u$ aangeven wat uw reactie op de opmerkingen is.

\begin{tabular}{|c|c|c|c|}
\hline $\begin{array}{l}\text { helemaal } \\
\text { mee eens }\end{array}$ & $\begin{array}{l}\text { beetje } \\
\text { mee eens }\end{array}$ & neutraal & $\begin{array}{l}\text { beetje } \\
\text { niet mee } \\
\text { eens }\end{array}$ \\
\hline
\end{tabular}

1. Mensen denken dat ik anders ben omdat ik ademhalingsmoeilijkheden heb

1. 2

3

4

5

2. Het feit dat ik ademhalingsmoeilijkheden heb, maakt dat ik me beschaamd voel

3. Wanneer je eenmaal in een ziekenhuis gelegen, behandelen mensen je anders dan daarvoor

4. A.ls je ademhalingsmoeilijkheden 1 2 3 5 hebt, denken andere mensen dat je geestelijk een kneusje bent

5. ledereen kan aan je zien dat je ademhalingsmoeilijkheden hebt

6. Mensen geven meer om je wanneer je gezond bent

1

2

\section{3}

5

2

\section{3}

\section{BULAGE II}

Angst bij benuuwdheid; Asthma Symptom Checklist (Kinsman, 1973)

De volgende vragen gaan over wat $\mathrm{u}$ voelt als $\mathrm{u}$ benauwd bent.

Stelt u zich voor dat u last heeft van benauwdheid. Wilt u met een kruisje aangeven hoe u zich dan voelt.

lk voel me dan.....

1. Zenuwachitig

2. Bezorgd

3. Bang

4. Paniekerig

5. Angstig

6. Bezorgd voor aanval

7. Bezorgd over mezelf

8. Bang dat ik dood ga

9. Nerveus

10. Gespannen

\begin{tabular}{|c|c|c|c|}
\hline nooit & bijpa & $\begin{array}{l}\text { soms } \\
\text { nooit }\end{array}$ & bijna \\
\hline nooit & bijna & $\begin{array}{l}\text { soms } \\
\text { nooit }\end{array}$ & bijna \\
\hline nooit & bijna & $\begin{array}{l}\text { soms } \\
\text { nooit }\end{array}$ & bijna \\
\hline nooit & bijna & $\begin{array}{l}\text { soms } \\
\text { nooit }\end{array}$ & bijna \\
\hline nooit & bijna & $\begin{array}{l}\text { soms } \\
\text { nooit }\end{array}$ & bijna \\
\hline nooit & bijna & $\begin{array}{l}\text { soms } \\
\text { nooit }\end{array}$ & bijna \\
\hline nooit & bijna & $\begin{array}{l}\text { soms } \\
\text { nooit }\end{array}$ & bijna \\
\hline nooit & bijna & $\begin{array}{l}\text { soms } \\
\text { nooit }\end{array}$ & bijna \\
\hline nooit & bijna & $\begin{array}{l}\text { soms } \\
\text { nooit }\end{array}$ & bijna \\
\hline & bijna & $\begin{array}{l}\text { soms } \\
\text { nooit }\end{array}$ & bijna \\
\hline
\end{tabular}


Ervaren kortademigheid; The Chronic Respiratory Disease Questionnaire (Guyatt, 1987a).

Wilt $u$ aangeven hoe kortademig $u$ zich de afgelopen twee weken voelde bij de volgende activiteiten:
1. Aankleden
a. heel erg kortademig
b. erg kortademig
c. nogal kortademig
d. een beetje kortademig
c. helemaal niet kortademig

De overige items betreffen de volgende activiteiten:

Een bad of douche nemen; voorover buigen; iets dragen, zoals boodschappen; boosheid; eten; een wandeling maken; huishoudelijk werk doen; haasten; het bed opmaken; de vloer dweilen of schrobben; meubilair verplaatsen; spelen met kinderen of kleinkinderen; sponten; iets boven je hoofd pakken (bijv, van een hoog schap); rennen (bijv. om de bus te kunnen halen); boodschappen doen; proberen in slaap te komen; praten; stofzuigen; een rondje rond het huis lopen; een heuvel oplopen; traplopen; samen met anderen een wandeling maken (gelijkvloens); eten klaarmaken.

\section{BUL_AGE IV}

Ervaren sociale steun; Sociale ondersteuningslijst (Van den Borne \& Pruyn, 1983).

De vragen die u nu aantreft gaan over uw ervaringen met contacten met andere mensen gedurende de afgelopen twee weken. Geef uw mening weer door een rondje te zetten om het antwoord dat op u van toepassing is. Ondervond $u$ in het contact met mensen gedurende de afgelopen twee weken:
1. Warmte en vriendelijkheid
a. nooit
b. soms
c. geregeld
d. vaak

2. Onbegrip

3. Waardering

4. Dat u minder hulp kreeg dan waar u behoefte aan had

5. Dat iemand een prettige tijd met u doorbracht

6. Dat iemand u kleineerde

7. Dat u te weinig informatie kreeg

8. Begrip en sympathie

9. Nuttige informatie en suggesties

10. Overbezorgdheid

II. Dat iemand u ontliep.

12. Hulp van een ander

13. Dat iemand u niet serieus nam

14. Dat men u niet met rust wilde laten

15. Dat iemand vertrouwen in u had

16. Dat iemand de tijd nam om bij u te zijn 


\section{BULAGE V}

Kunnen praten over de aandoening; Sociale ondersteuningslijst (Van den Borne \& Pruyn, 1983)

De volgende uitspraken gaan over het praten over uw ademhalingsmoeilijkheden (en de gevolgen ervan), met mensen uit uw directe omgeving. Zou u bij elke zin die u leest willen aangeven in hoeverre u het ermee eens bent.

1. Ik praat zo weinig mogelijk over mijn aandoening omdat ik anderen niet ongerust wil maken.
a. zeer mee eens
b. mee eens
c. niet mee eens
d. helemaal niet mee eens

2. Als ik met anderen over mijn aandoening of problemen praat, ben ik het zelf meestal die daarover begint.

3. Mijn partner of mijn beste vriend(en) heeft liever niet dat ik over mijn aandoening en problemen praat.

4. Mijn kinderen hebben liever niet dat ik over mijn aandoening en probiemen praat.

5. Als ik over mijn aandoening praat, praten anderen er snel overheen.

6. Mijn gezin of anderen uit mijn directe omgeving willen altijd alleen horen dat het goed met me gaat.

7. Praten over gevoelens in verband met mijn aandoening maakt mijn gezin of anderen uit mijn directe omgeving overstuur.

8. Mijn partner of mijn beste vriend(en) weet vaak niet wat te zeggen of te doen, als ik het moeilijk heb.

9. Mijn kinderen weten vaak niet wat ze moeten zeggen of doen, als ik het moeilijk heb. 
De auteur van dit proefschrift werd geboren op 10 augustus 1955 te 's Hertogenbosch. Na een Atheneum-opleiding begon hij met de studie Psychologie aan de Rijks Universiteit Groningen, alwaar hij in 1984 als klinisch en ontwikkelingspsycholoog afstudeerde. Aansluitend is hij als psycholoog werkzaam geweest bij het RIAGG te Groningen (1984-1985), het Nederlands Astmacentrum Davos (1985-1991) en het Psychotherapeutisch Centrum De Viersprong' te Halsteren (1991-heden).

Lidmaatschappen en registraties:

- Registratie Psychotherapeut, ministerie van VWS

- Registratie Klinisch Psycholoog en supervisor, Nederlands Instituut van Psychologen,

- Gewoon lid en supervisor, Vereniging voor Gedragstherapie

- Gewoon lid en supervisor, Vereniging voor Kinder- en Jeugdpsychotherapie

- Lid werkgemeenschap 'Gedragsfactoren bij Somatische Aandoeningen', NWO

- Lid werkgroep Sociaal Wetenschappelijk CARA-onderzock, Nederlands Astma Fonds 


\section{DANKWOORD}

Allen die bij het tot stand komen van dit proefschrift behulpzaam zijn geweest ben ik veel dank verschuldigd.

Met naam wil ik noemen:

Prof. dr. A. Appels, mijn eerste promotor, die mij op de juiste momenten op het rechte wetenschappelijke pad wist te houden.

Dr. A. Kaptein, mijn tweede promotor, die er vanaf het begin bij was en mij onder meer het noodzakelijke onderzoekersvertrouwen gaf.

Dr. F. Dekker, voor de antwoorden op mijn vele vragen aangaande de statistiek.

$J$. Cool, voor het programma's orn de data op te slaan.

$R$. Bol, voor het zorguuldig verzamelen van die data.

Prof. dr. G. Kooij (schoonvader eerste reserve), voor de stimulans en het becommentariëren van onderdelen van het manuscript.

J. Kruit voor het regelen van tijd en geld.

De leden van de beoordelingecommissie, Prof. dr. J. Bremer, Dr. J. Dekker, Prof. dr. E. Klip, Prof. dr. J. Knotmerus en Prof. dr. E. Wouters, voor hun opbouwende kritiek op de laatste versie van het manuscript.

De patiënten, die deel wilden uitmaken van de onderzoekspopulatie.

Mijn ouders voor de geboden bagage.

Mijn schoonouders voor de interesse.

Last but not least: Linda, Kim, Lenny en Onno. 

